\title{
Intimations of Mortality: Death in Children's Fantasy
}

\author{
by
}

Angelina Sbroma

\begin{abstract}
A thesis
submitted to the Victoria University of Wellington in fulfilment of the requirements for the degree of

Doctor of Philosophy

in English Literature
\end{abstract}

Victoria University of Wellington

2018 



\begin{abstract}
"Children's books have always been filled with death," Patrick Ness writes in his review of Neil Gaiman's The Graveyard Book. "You can't have an orphan without at least two dead people, after all." Literary childhood, from its origins, is not only associated with, but commonly defined by the experience of loss. This thesis argues that children's literature is fixated on endings; that it is marked by the insistent, and persistent, presence of mortality. Further, it argues that mortality is not just a prevalent theme, but a fundamental organising principle both thematically and structurally, working to define the genre and shape its form and substance.
\end{abstract}

The mortal notes in children's literature are an inevitable effect of the peculiar conditions of its production. Children do not, for the most part, write their own literature: it is written by adults who necessarily write to, of, and for the child from a point in time irrevocably apart from it. Critic Jacqueline Rose has famously articulated the "acknowledged difference, a rupture almost, between writer and addressee" on which children's literature rests. The overwhelming presence of mortality in the genre is a direct effect of the rupture at its heart: inevitably aware of the acknowledged difference between writer and addressee, and filtered through adult memory and imagination, literary childhood cannot help but be framed as eulogy and elegy, constructed as the beginning of an ending.

This reading, then, addresses the gap between adult and child that has occupied children's literature criticism for almost thirty years, but it moves beyond questions of power and control to focus on its creative effects. The thesis explores mortality and the construction of literary childhood in relation to adulthood in a range of fantasy subgenres. It begins with the classics of the Victorian Golden Age, exploring the writing of childhood at the origins of modern children's fantasy. The chapters on animal stories, toy stories and ghost stories all shed light on the figuring of childhood through close association and identification, each foregrounding particular qualities with which literary childhood is invested. In animal 
characters, primacy is given to an intense and largely contextless vitality, to an orientation in a paradoxically eternal and eternally fleeting present moment. Toys are memory boxes, highlighting the importance of the child (and children's literature) as a lieu de mémoire. Ghost characters emphasise the ways in which childhood is figured as past and as haunting, memorialised even in its presence. In time-slips and alternate world fantasy, the dissonant once-and-future oriented, mortal qualities of literary childhood manifest themselves in the manipulation of the time and space of setting.

But as dependent as the impulse to elegy is on difference, it also depends for its entire effect on the inescapable continuity between adult and child. Put another way, we were once them. They will be us. That the "impossible" relation between adult and child is so neatly encapsulated by the memento mori - "that which you are, we were; that which we are, you shall be" - speaks to how and why mortality casts so deep a shadow in the literature. 


\section{Acknowledgements}

It takes a village, as it turns out, and there are many whose help and support were instrumental in bringing this thesis to completion, and to whom I am more grateful than I can express.

First and foremost, I would like to thank my supervisors, Anna Jackson and Geoff Miles, for their keen observation and insight, their astute questions, their rigour, their dedication, their encouragement, and their whole-hearted belief. Under their guidance and direction, this project flourished, and I became a better scholar, and a better writer. I couldn't have asked for more, and I couldn't be more thankful.

Thank you to the staff and post-graduate community of the Department of English Literature at Victoria, for providing such a wonderful, open, intellectually curious, and encouraging academic environment in which to work. I am grateful for the friends I have found there, for the enthusiastic support of the department as a whole, for the illuminating and often hilarious conversation, and for the cups of tea and coffee.

Thank you to the scholarships office of Victoria University of Wellington for granting me the scholarship that enabled my research. Thank you also to the Faculty Research Committee for giving me the means to travel for research and conference purposes.

Thank you to Sarah Dillon, and to Emily Brouwer, who helped me to proofread the final draft, for their keen eyes and their kindness. You are both most brilliant, and any errors left are my own.

To my friends for their love and support over the course of these years, particularly Anna, Helen, Sonya, Callie, Emily, Malcolm, and Sean, who let me lean on them through the hardest times, and celebrated with me in the joyous ones: I'm more grateful than I can say.

To my sisters, Lina and Nicky, and especially to my precious mother, Anna, whose strength and support I couldn't have done without: thank you for everything you do, every day.

And finally, to my father, Sergio, for his love and his pride in me, and for influencing and shaping this work in ways I could never have anticipated at the outset: my deepest love and gratitude. 


\section{Table of Contents}

Abstract $\quad$ i

Acknowledgements $\quad$ ii

List of Figures $\quad$ vi

Introduction: $\quad$ Intimations of Mortality: Beginnings and Endings $\quad 1$

Chapter 1: $\quad$ Wonderlands and Afterlives: Victorian Children's Fantasy

Chapter 2: $\quad$ Instinct and Appetite: Animal Stories

Chapter 3: $\quad$ Memory and Legacy: Toy Stories

Chapter 4: $\quad$ Haunted and Haunting: Ghost Stories

Chapter 5: $\quad$ Fleeting and Eternal: Time-Slip Fantasy

Chapter 6: $\quad$ There and Back: Alternate World Fantasy

177

Coda:

Fantasy and Mortality: The Ocean at the End of the Lane

213

Works Cited

223 


\section{List of Figures}

Figure 1: The Stones of Green Knowe ...................................................164 


\title{
Introduction
}

\section{Intimations of Mortality: Beginnings and Endings}

\author{
Quello che siete \\ What you are \\ fummo. \\ Quello che siamo \\ sarete \\ we were. \\ What we are \\ you will be.
}

Italian Memento Mori (The Voices of the Dead) ${ }^{1}$

J.M. Barrie's Peter and Wendy (1911) begins with a famous and oft-quoted statement about childhood and its fleeting, temporary quality: "All children, except one, grow up" (55). This may seem a strange place for Barrie to begin, in a work that has become one of the great cultural myths of eternal childhood. From the first, however, it is clear that Barrie constructs childhood in Peter and Wendy in relation to its ending. The lines immediately following this famous declaration make this relation explicit:

They soon know that they will grow up, and the way Wendy knew was this. One day, when she was two years old she was playing in a garden, and she plucked another flower and ran with it to her mother. I suppose she must have looked rather delightful, for Mrs Darling put her hand to her heart and cried "Oh, why can't you remain like this forever!" This was all that passed between them on the subject, but henceforth, Wendy knew that she must grow up. You always know after you are two. Two is the beginning of the end. (55)

There are a number of things to note about this opening. The central image is not just of a child at play in a garden (a site both of natural growth, and of careful cultivation). It is of a child under the gaze of an adult. Wendy is "delightful," temporarily free from an awareness of time and its effects; Wendy's mother, confronted with this blithe unawareness, is moved to

\footnotetext{
${ }^{1}$ The source for this particular iteration of memento mori is a plaque on the wall outside the cemetery in Bojano, Italy, where my paternal grandparents are buried.
} 
a kind of pre-emptive mourning. Mrs Darling sees, in the vision of the child before her, not that child's vital presence, but the ghost of the child Wendy will one day no longer be. Mrs Darling's awareness of inevitable endings is passed between Mrs Darling and Wendy - it is a direct outcome of relation between them - and this awareness becomes ("henceforth," as Barrie writes) a condition of Wendy's present childhood. After she is two, Wendy hears, so to speak, the ticking of a distant crocodile. There is a link drawn in this passage between the end of childhood and a larger, more permanent end, and the child figure here encapsulates both a wish for the eternal, and an acknowledgement of the fleeting.

Literature - and children's literature in particular - must construct the child (as Barrie does in the above passage) rather than simply describe it. ${ }^{2}$ This thesis argues that childhood in children's literature is always constructed as both eternal and fleeting, that it is constructed as the beginning of an ending. Children's literature is intimately concerned with endings: death is, indeed, so common a concern as to be almost ubiquitous. Frances Hodgson Burnett's Sara Crewe, for example, loses her mother; the "little women" of the March family must endure the death of their sister, Beth. Travis is forced to shoot Old Yeller. Anne Shirley and Hatty Melbourne (from L.M. Montgomery's Anne of Green Gables and Philippa Pearce's Tom's Midnight Garden respectively) are orphans when their tales begin, as are Wart in The Sword in the Stone, Nobody Owens in The Graveyard Book, and Sophie in The BFG. Lyra Belacqua, the heroine of Philip Pullman's His Dark Materials trilogy, loses both of her parents and her best friend Roger before her story's end; Harry Potter must grieve for his parents, his godfather, his favourite teacher, his mentor, many of his friends, and even his pet owl Hedwig, before his own death - however temporary - in fulfilment of prophecy. The child protagonists in children's literature commonly face mortality in many different guises, and must cope with various kinds of loss. The insistent and persistent

\footnotetext{
${ }^{2}$ Robert Pattison, in The Child Figure in English Literature, writes that the literary child is often misread as straightforwardly descriptive, and that this is a source of power: "Children are figurative, at least as they appear in English literature over the past 300 years. [...] The reader or viewer, coming across a child, will be tempted to say, 'Well, here is something from real life, not a figure, but just what it seems to be - a child.' The fact that the child is not regarded as a figure or image gives it potency..." (44).
} 
presence of mortality in children's fiction - so persistent, indeed, that it becomes almost unremarkable - might come as a surprise. This is a literature, after all, that is popularly regarded as sanitised and escapist. It is arguable, however, and this thesis does argue, that a focus on endings is central and fundamental to children's literature, an inevitable effect of the peculiar conditions of its production.

It is a commonplace of children's literature criticism that the genre is unique in being defined by the depth and breadth of the gap between writer and reader. Children do not, for the most part, write their own books: children's books are written by adults who must write to, of, and for children from a moment in time irrevocably separated from the presentness of childhood. It follows that the construction of childhood in children's literature is inevitably informed by the distance of the adult in relation to it. Writing to, of, and for the child involves a deliberate contemplation of the workings of time and memory; of how the past acts on the present; of how the present inevitably shifts into future. The child figure is an embodiment of a past the adult cannot regain ("a past that, while constantly escaping us, is nevertheless omnipresent" (Krips, The Presence of the Past 9)), and a future the adult will not live to see. As such, the literary child becomes, as Carolyn Steedman writes in Strange Dislocations, "representative of a lost realm, lost in the individual past and in the past of the culture" (4). Sarah Gilead points out that "[o]nly after childhood ends can the adult reconstitute it as the object of desire, so that the concept originates in loss" ("Magic Abjured" 96).

This thesis argues that the sense of an ending (founded in loss) pervades the literary construction of childhood in children's fantasy. As the passage from Peter and Wendy quoted above demonstrates, this sense of an ending manages be both impending and remembered, reflecting the child figure's peculiar temporal positioning. The child in literature is emblematic of both past and future, even as it also symbolises an intense and fleeting present vitality. As a temporal symbol, the literary child recalls the mottos traditionally inscribed on sundials: "Even As You Watch, I Am Fleeing," is one example of 
such a motto, "Soon Comes Night," another. "Take the Gifts of this Hour," admonishes a third, a fourth, "It Is Later Than You Think." 3 All of these mottos are akin to memento mori. In the context of this temporality, the close alignment of childhood with mortality in children's literature is not a surprise so much as an inevitability; it is an alignment that lies at the heart of the literature's creation.

The relation between the adult and the child at heart of children's literature has occupied children's literature criticism for over thirty years, ever since the publication of Jacqueline Rose's landmark The Case of Peter Pan, or the Impossibility of Children's Fiction in 1984. This work is foundational, both in its articulation of the way that children's literature rests on an assertion of "acknowledged difference," gap, or rupture between adult and child (The Case of Peter Pan 1), and in its consequent claim that children's fiction is "impossible" because (as Clémentine Beauvais neatly summarises) "the adult-child relationship it posits rests on at least one hollow signifier" (The Mighty Child 15). In Rose's own words:

Children's fiction rests on the idea that there is a child who is simply there to be addressed, and that speaking to it might be simple. It is an idea whose innocent generality covers up a multitude of sins. (The Case of Peter Pan 1)

The difference of the child - or rather, childhood conceptualised as a state separate and distant from adulthood - is central to the enterprise of children's literature. Children would not have a separate and dedicated literature at all, if they were not considered a distinct audience in need of such a literature. ${ }^{4}$ But a certain conceptualising of difference is also central to the origins of children's fantasy altogether. At the point in the mid-to-late nineteenth century at which fantasy, in particular, emerged as a genre for children, it was as

\footnotetext{
${ }^{3}$ These examples are taken from S-Town, a 2017 podcast about (among many other things) death and horology. The entire podcast can be found at https://stownpodcast.org/.

${ }^{4}$ Critics who have made this point explicitly include Perry Nodelman in The Hidden Adult (2008), Maria Nikolajeva in Power, Voice, and Subjectivity in Literature for Young Readers (2010), and Karín LesnikOberstein in "Defining Children's Literature and Childhood" (1996).
} 
part of a larger cultural conversation in Victorian society about the nature and qualities of childhood, and where the child stood in relation to adulthood. There was an associated debate about children's literature itself, and about whether that literature could, or should accord with Rousseau's famous assertion that "[c]hildhood has its own ways of seeing, thinking and feeling" (Emile, or Education 54).5 Inquiry into the nature of childhood occupied a central position in Victorian discourse (and indeed, in Victorian children's literature) long before the seminal study of Philippe Ariès pushed childhood, both as a cultural construction, and as an historically contingent and evolving critical concept, into the mainstream of social science, history, and historiography in the academy. ${ }^{6}$ The origins of children's literature and children's fantasy are bound up with, and inextricable from questions of what the child is and how to address it.

Victorians became invested in the idea that the child might be able to be a thing apart. The Victorian era was characterised by rapid and unsettling cultural and social revolution; this revolution engendered a widespread sense of cultural uncertainty, which was deeply felt by Victorians themselves. Thomas Carlyle writes of his own society in an 1831 essay entitled "Characteristics":

Never since the beginning of Time was there, that we hear or read of, so intensely self-conscious a Society. Our whole relations to the Universe and to our fellowman have become an Inquiry, a Doubt. (366)

\footnotetext{
${ }^{5}$ This might seem an odd source, as reading any form of literature is anathema to the particular form of education that Rousseau espouses in Emile, which sees reading as having a distorting and colonising effect on the so-called "natural" child. Nevertheless the conception from which Rousseau derives his educational strategy - a definition of childhood as a space and time separate from adulthood - was a potent force in contemporary Victorian discourse about childhood, and often treated separately in that discourse from his ideas about education (see: Shuttleworth, The Mind of the Child, "Introduction").

${ }^{6}$ Ariès's study of childhood is entitled L'Enfant et la vie familale sous l'Ancien Régime (1960), and was translated into English as Centuries of Childhood in 1962. Hugh Cunningham's Children and Childhood in Western Society since 1500 (Second Edition 2005) provides a useful summation and evaluation of Ariès's work and the ensuing debate in the historiography of childhood, identifying three major schools of criticism (sentiment, household economics, and demographics), named for the major forces that have informed and shaped childhood as a cultural construction.
} 
According to traditional histories of children's literature, Victorians were moved, in the climate Carlyle describes, to seize on a conception of childhood as pre-self-conscious, as a time of reprieve from the doubt inherent in modernity. Childhood could be figured as safely remote and safely unsullied, untouchable because it had already safely passed into memory. It is here, perhaps, that we find the roots of the Arcadian impulse that Humphrey Carpenter traces in Victorian and Edwardian children's fiction (in Secret Gardens: A Study of the Golden Age of Children's Literature (1985)), not to mention the impulse towards the literary representations of childhood death that Judith Plotz discusses as part of the origins of children's fantasy, crucial to, as well as contemporaneous with, its emergence in the Victorian era ("Literary Ways of Killing a Child" (1995)). It is here, too, that we find the origins of the Victorian inflection on the Romantic child figure that is so important both in the history of the child, and in the history of the child's literature.

The Romantic child figure - theorised as what Mitzi Myers calls a collection of "commonplaces essentializing the child as imaginative, intuitive, spontaneous, free" ("Reading Childhood and Homeopathic Romanticism" 44) - is commonly traced back to the "child of nature" in the poetry of William Wordsworth. In "Children of Childhood," Linda Austin claims that it is Wordsworth's belief in the "unrecoverability of the condition of childhood" that most influenced and shaped Victorian thinking:

This belief was expressed most memorably for Victorians in "Ode: Intimations of Immortality" (1807), which treats the loss, awe, and estrangement framing the adult's sense of childhood as features of a common psychological profile. The "Ode" evokes a shared sense among adults of inevitable forgetting, of the remoteness of the condition of childhood. (83)

Austin goes on to stress that childhood in Wordsworth's "Ode" (in contrast to that in his Prelude) is not just remote, but extraordinary. It is a condition of infinite possibility, and of "vivid and at times visionary perception which fades with age and severs the being of the child from that of the adult." In the hindsight of adulthood, Austin continues, "childhood 
becomes the one period in which everyone's genius seems to have glimmered" (83). This is a neat summation and articulation of the attraction for Victorians in the canonical formulation of Romanticism. This conception of the Romantic child is elaborated on by Judith Plotz, in Romanticism and the Vocation of Childhood (2001), who notes the tendency of the male Romantics to "produce children not as integrated into the social realm, but as a race apart" (xv):

[The Romantic Child as an] essential timeless figure is principally produced by two initiatives: the identification of childhood with Nature-both as Law and as the green world-and the attribution to children of an autonomous, unitary consciousness. [...] children are regularly depicted as the indigenes of nature: at once originary models of ideal nature, unselfconscious and self-sufficient models of natural beauty and irrepressible engines of vital power. (5-6)

The child, here, is imbued with qualities that are figured as both universal and essential: this is a figure of nature rather than of culture. Such a formulation is notable in its emphasis on origins (as Wordsworth makes clear), but it is also notable in its (characteristically) dual construction:

The identification with natural law means that children can be figured in both fixed and dynamic terms, as likely to be figures of abiding being as figures of surging vitality. (Plotz, Romanticism and the Vocation of Childhood 6-7)

At the heart of the "natural" Romantic child, then, are the dissonant and opposing impulses that characterise the writing of mortal childhood in Victorian fantasy: the impulse towards fixity and stasis on the one hand, and towards irrepressible momentum and dynamism on the other.

Alan Richardson notes that "nineteenth-century children's literature, both in Britain and America, is pervasively indebted to canonical Romanticism" (Romanticism and the End of Childhood" (172)). It is certainly true that the Romantic child figure is central to 
traditional critical histories of children's literature. Such histories, including F. Harvey Darton's foundational Children's Books in England: Five Centuries of Social Life, published in 1932, and John Rowe Townsend's equally influential Written for Children: An Outline of English Language Children's Literature (first edition 1965), lean heavily on ideas of the Romantic essential child in their descriptions of the emergence of fantasy literature for children as the triumph of imagination over didacticism. Mitzi Myers, speaking of children's literature critics, has called the Romantic child "our founding fiction, our originary myth," and remarks on "just how hard it is to distance ourselves from the 'always already' saidness of the Romantic literary discourse on childhood almost any critical analysis or historical overview [of children's literary studies] that comes to hand readily (if sometimes inadvertently) testifies" ("Reading Childhood and Homeopathic Romanticism" 45).

This canonical framing of Romantic attitudes to childhood has been thoroughly complicated and revised in the work of scholars such as Myers and Richardson, 7 but it is important to acknowledge the canonical formulation as central, both as a founding precept in the philosophical, social, and literary history of children's fantasy literature, and as a continually potent force in that literature's development and current form. Ann Weirda Rowland articulates why the Romantic construction of childhood has been so remarkably tenacious over the nineteenth and twentieth centuries, even as many of the other philosophical underpinnings of Romanticism have been undermined and superseded:

the ideas associated with childhood that emerged in the Romantic period, and the rhetoric and images that gave them shape, became foundational to the dominant cultural and historical paradigms of the nineteenth and twentieth centuries, and thus to how, for a significant period of time, we have explained the world. (Romanticism and Childhood: The Infantilization of British Literary Culture 10)

\footnotetext{
${ }^{7}$ The respective essays of Myers and Richardson in the collections of James Holt McGavran - Romanticism and Children's Literature in Nineteenth-Century England (1991) and Literature and the Child: Romantic

Continuations, Postmodern Contestations (1999) - are particularly interesting and instructive in this regard, as is Richardson's longer work, Literature, Education and Romanticism: Reading as Social Practice, published in 1994.
} 
The Romantic child is certainly central to the argument that Jacqueline Rose makes in The Case of Peter Pan, which posits that children's fiction is based on an innate contradiction, "purporting to be about children when it is really about adults, who figure the child for their own purposes" (Rudd, "Border Crossings" 63). Rose argues that "[c]hildren's fiction has never completely severed its links with a philosophy which sets the child up as a pure point of origin in relation to language, sexuality, and the state" (The Case of Peter Pan 8). Rose's objection to this conception of childhood is at the root of her argument that children's fiction "sets up the child as an outsider to its own process, and then aims, unashamedly, to take the child in" (2). In other words, Rose sees children's literature as falsely aligning the figurative child with a Romantic pure point of origin, and then attempting to fix that Romantic innocence on the child outside the text: "Children's fiction draws in the child, it secures, places and frames the child" (2). But the very same conception of pre-linguistic innocence that Rose objects to lies at the foundation of her (by now notorious) articulation of the "impossibility" of children's literature:

Children's fiction is impossible, not in the sense that it cannot be written (that would be nonsense), but in that it hangs on an impossibility, one which it rarely ventures to speak. This is the impossible relation between adult and child. Children's fiction is clearly about that relation, but it has the remarkable characteristic of being about something which it hardly ever talks of. (1-2)

An argument of impossibility necessarily posits a child who is unable to be reached linguistically, and cannot reach back: a child, in effect, who is a race apart.

So important has The Case of Peter Pan been in children's literature criticism, that Clémentine Beauvais has, only slightly tongue-in-cheek, borrowed Alfred North Whitehead's famous terminology to claim that "English-speaking children's literature theory might be said to have been, since 1984, a series of footnotes to Jacqueline Rose" (The Mighty Child 15). The critical debate has focused, for the most part, on issues of power and control over the territory of children's books; on whether, in a genre over which adults have almost 
unilateral control, there is any potential at all to avoid what Peter Hunt calls "an inevitable, and often radical imbalance of power" in which the child both inside and outside the text is at the mercy of adult dominance and distortion ("Unstable Metaphors" 23).

The child figure in children's literature, according to this line of argumentation, is necessarily conceived by adults to define the adult and adult values, offering the child as what Tim Morris calls "adulthood's inferior, distorted, and somehow dangerous negative" (You're Only Young Twice 11). Rose's ideas have been widely applied: Perry Nodelman, for example, in "The Other: Orientalism, Colonialism and Children's Literature" takes up the idea of the child as a hollow signifier, applying Edward Said's concept of Orientalism directly to the enterprise of children's literature. Childhood in children's books, according to this reading, is invented and distorted (as opposite, female, inferior) in order to create, affirm, and perpetuate adulthood's construction of itself. Karín Lesnik-Oberstein takes this line of thinking even further: not only children's literature, but also children's literature criticism, she argues, is fatally compromised by its reliance on the concept of an essentialist "real" child, and on childhood as knowable at all, or as existing as anything but an adult construction ("Childhood and Textuality" 20).

While it is crucial to acknowledge adult power over the production and territory of fiction for children, and to acknowledge, too, the cultural power being wielded by the genre as a whole, constant re-litigation of this question in the criticism tends to ignore the ways that the gap at the centre of children's literature acts as a positive shaping of the genre. Consequently, the argument being made in this thesis is not primarily about power and control. Instead, it is concerned with the creative effects of the gap in the adult-child relation, and with examining what happens, in literary terms, when adults write to, of, and for the child. Reading children's fantasy as a series of intimations of mortality reframes the gap into a generative possibility rather than an impossible obstacle. This reading both acknowledges and moves beyond inherent questions of control to explore how and why the literature manifests as it does. 
Although the focus in this thesis on mortality may seem to be an endorsement of Rose's formulation of the adult-child relation as "impossible" - perhaps even a demonstration of her claim that this literature works to secure and frame the child in precisely the manner she sees as so fatally problematic - I argue that reading mortality as both structural and foundational to children's fantasy works to counter and complicate Rose's characterisation of the genre in a number of ways. Reading mortality in children's fantasy, to begin with, does not deny the enduring rhetorical and literary possibilities of the Romantic conception of childhood as difference. Such a denial would misrepresent children's literature, refuting a formulation that is openly avowed by children's authors to be a continuing force in their work. Penelope Lively, for example, writes in a 1987 essay, "Bones in the Sand," that:

"[c]hildren live in another country; and although it is one we have all passed through, to pass beyond it is to have lost, irretrievably, I believe, its language and its beliefs. We have lost the sense of a continuous present and have moved into an awareness of what has been and what is yet to be and of our own situation in relation to time - both personal time as the context of a life and collective time, history. (13)

The peculiar temporal positioning of the child figure makes it something of a lightning rod for the sense of distance and loss that Lively describes: this sense of loss works to engender the mortal shadow that hangs over literary childhood. But it is also clear in the way that Lively positions childhood in relation to adulthood that when childhood is figured teleologically - as informed and defined by its ending - mortality does not depend on images of fixity or stasis. Mortality is not only expressed, that is, in images of the dead or fixed child; it is also expressed in the acknowledgement, also universally present in children's fantasy, of the inevitable growth of the socialised and acculturated child. Growth, in this reading, is an ending in itself, and depicted with the same mortal shadow. 
It does not follow, therefore, that traditional Romantic conceptions of childhood are wholeheartedly endorsed in a reading of children's fantasy as underpinned by mortality. It would also be a serious misrepresentation of children's literature to deny, as Rose does, the ambivalence and tension inherent in its depiction of childhood. David Rudd points out the irony of the way that Rose's objection to the canonical Romantic child figure works to assert and reinforce its power:

[The Case of Peter Pan] does not [...] represent closure, the end of children's literature and children's literary criticism because of some impossible, insurmountable aporia, as some have suggested. To become fixated on the area's impossible status is, in effect, to hold on to the remnants of a Romantic child figure: a being that somehow stands apart from the general language community so that it either cannot be addressed (unlike more mature readers) or, if it can, its responses cannot be known [...]. To turn this around, children's fiction thereby becomes peculiar as one of the few forms of communication unable to address the child. ("Children's Literature and the Return to Rose" 303)

Marah Gubar's Artful Dodgers: Reconceiving the Golden Age of Children's Literature adroitly elaborates on this point:

While I certainly don't wish to deny that children's texts function ideologically, as tools often employed by adults in an effort to socialize, shape, or even indoctrinate children, my concern is that such highly charged rhetoric resurrects the very image of childhood to which Rose herself so cogently objects. [...] by implying that child readers inevitably succumb to adult efforts to regulate and exploit them, such discourse itself 'others' children by characterizing them as innocent naïs whose literary skills are too primitive to enable them to cope with the aggressive textual overtures of adults. (31)

Children's fantasy has always been an arena where adulthood's complicated and dissonant impulses in relation to childhood are represented and worked out. While Alan 
Richardson notes that the Romantic phenomenon that is "[t]he culturally dominant construction of childhood" is "one that becomes more visible as its dominance begins to recede and its inevitability is called into question" ("Romanticism and the End of Childhood" 172), it is arguable that the so-called "inevitability" of the Romantic construction was questionable even for the Victorian originators of fantasy for children. Fiona McCulloch, in The Fictional Role of Childhood in Victorian and Early Twentieth-Century Children's Literature, makes the point that "this period does not simply uphold the mythical status of innocent childhood promoted by Victorian society but, on the contrary, actively intervenes in contemporaneous discourses and, in doing so, adds its own crucial and often subversive voice to the cultural study of childhood" (1). Marah Gubar's Artful Dodgers makes a very convincing case for precisely this: while acknowledging the power and relevance of the Romantic child figure to the Golden Age writers of childhood, Gubar works to reconceive their fiction as far more nuanced and sceptical about Romantic primitivism than traditional critical accounts suggest (5). Golden Age writers of childhood were far from being sure of the status of the child as innocent and untouched by the social and cultural forces of the modern world. Instead they framed childhood, and adulthood's relation to it (and the relation of both to mortality) in much the same way that Thomas Carlyle framed Victorians' "whole relations to the Universe and to our fellow-man": as an Inquiry, a Doubt.

This thesis, then, frames mortality in children's fantasy as an instrument of open inquiry and negotiation about what literary childhood is, and how it is constructed. Rose's denial of the possibility that children's literature might be a site of negotiation at all - or, paraphrasing Gubar, Rose's "habit of implying" that the child outside the book has no recourse against the literary child inside the text (Artful Dodgers 31) - is flawed and incomplete in its disregard of children's literature working as literature, conceptualised as an act of communication between author and reader. ${ }^{8}$ Critics who have attempted to address

\footnotetext{
${ }^{8}$ Wolfgang Iser's conception of the implied reader is of obvious importance in a conception of literature as communication. Iser posits literature as a "negotiation of insight" between author and reader (The Implied Reader 57), in which the creation of meaning requires the reader's "creative participation" (275). Aidan Chambers applies this formulation directly to children's literature in "The Reader in the Book": "if literature is a
} 
this in children's literary theory include David Rudd in "Children's Literature and the Return to Rose," cited above, who advocates for a Bakhtin-inflected approach to children's literature, one which "sees the area's whole development [...] in dialogical terms" (291). Victor Watson conceives of children's literature as a "cultural space [...] in which children and adults can engage in various kinds of shared and dynamic discourse." Children's fiction, he argues in direct counterpoint to Rose, is an arena which fosters "the creation of possibilities" ("The Possibilities of Children's Fiction 11, 12 italics in original). Peter Hollindale in Signs of Childness in Children's Literature does not discuss Rose's work at all, but posits in counterpoint all the same a negotiation between author and reader about the meaning and nature of childhood as a distinguishing feature of children's books. So does Perry Nodelman in The Hidden Adult, which directly contradicts Rose's assertion that children's literature "rarely ventures to speak" of the fraught adult-child relation at its heart: Nodelman claims, persuasively, that one of the unifying characteristics of texts for children is their "open discourse about what children are, about how they are different from adults, and about the relative merits of the different qualities" (22).

This thesis argues that mortality inflects what children are in this literature: that, as a force in children's fantasy, mortality works to construct literary childhood as both eternal ("a cyclic, mythic state" (Nikolajava, From Mythic to Linear 5)), and at the same time, eternally fleeting. While the preoccupation with language and themes that confront mortality in children's fiction has often been noted in children's literature criticism, this thesis elevates that preoccupation to a fundamental organising principle, both characteristic of, and particular to fantasy for children: contemplation of mortality is both cause and effect of the complicated adult-child relation that distinguishes the genre. The tension between the eternal and the fleeting in children's fantasy demonstrates that far from rendering children's literature impossible, it is precisely the gap between adult and child that make this literature

way of saying something," Chambers writes, "it requires a reader to complete the work" (35). In a conception of literature as communication, there is no reason at all that children, as readers of literature, should be excluded from creative participation in their reading. 
possible, and goes on to illuminate how. This reading aligns itself with Watson and Nodelman against Rose's assertion that children's literature "rarely ventures to speak" of the adult-child relation: examined through the lens of its mortal themes and images, it might well be argued that children's literature rarely speaks of anything else.

So it is even in Rose's exemplary text, Barrie's Peter and Wendy, despite that work's popular status as a paean to eternal childhood. Mortality is everywhere in Barrie's depiction of Peter: death is the only state humans are capable of reaching that touches the eternal, after all. Peter is ghostly: clad in "skeleton leaves and the juices that ooze out of trees" (60), and "so light that if you got behind him and blew he went faster" (82). Peter doesn't need to eat, and that he fails to have a presence in time at all is made clear by the constant forgetting with which he is characterised: he forgets both his closest companions ("Who is Tinkerbell?" he asks on one of his return visits to Wendy, "I expect she is no more"), and his greatest foes ("Who is Captain Hook? [...] I forget them after I kill them" (172)). Existing as he does outside of time, Peter can make no memories.

It is even more notable, then, that Peter and Wendy begins and ends with a focus not on the eternal boy, but on the highly socialised and acculturated, very temporary girl who shares the title. Wendy's girlhood, in contrast with the eternal boyhood of Peter, is constructed in terms of fleetingness: her games, even in Neverland, look forward to the adult she dreams of being. She plays houses, and tells bedtimes stories, she constantly sews and mends, and dreams of giving Peter a real kiss. The opening of the story, as discussed above, describes the moment she first became aware of the ticking of the crocodile; the last chapter (entitled "When Wendy Grew Up") tells of the night the crocodile catches her: "And then one night," Barrie writes, "came the tragedy" (175). It is a tragedy long foretold: on the night she first meets Peter, Wendy learns that the careless boy never had a mother, and "felt at once that she was in the presence of a tragedy" (72). On the night of their last meeting, Wendy, now a mother herself, whose own mother is "dead and forgotten" (174), "let[s] her hands play in the hair of the tragic boy" (176), before standing up and revealing that she is "ever so 
much more than twenty," and can no longer fly to Neverland to play at being Peter's mother. Wendy's own daughter, Jane, shows a blithe unconcern for Wendy's heartbreak at no longer being able to fly. Upon being told that it is only the gay and innocent and heartless who can fly, Jane asks: "What is gay and innocent and heartless? I do wish I was gay and innocent and heartless" (175). The gay heartlessness of this question only underlines the weight of feeling (the opposite of heartlessness) that Wendy carries in comparison: she "huddle[s] by the fire not daring to move, helpless and guilty, a big woman," and "squeeze[es] herself as small as possible" (176). No wonder Wendy can't fly anymore. She gazes at Peter and Jane flying together with the same wish for the eternal expressed by her own mother in the opening paragraph of the novel.

On the night of the tragedy, Jane flies out towards Neverland in the company of Peter, with no thought to poor Wendy ("'You see you can't fly,' said Jane" (178)), and "[o]ur last glimpse of [Wendy]," we are told, "shows her at the window, watching them receding into the sky until they were as small as stars" (178). This is a deliberate reflection and echo of Peter, the strange (ghostly) boy - the tragedy - left outside on the night that Wendy and her brothers returned from Neverland to be reunited with their family; the boy who looked "through the window at the one joy from which he must be for ever barred" (169). This mirrored image draws an explicit link between the dead boy and the grown girl, and the end of childhood is depicted in mortal terms.

It is in these mortal terms that I examine the construction of childhood in nineteenth- and twentieth-century children's fantasy. I have chosen to focus on fantasy in particular because of the clear ways that fantasy explicitly manipulates character and setting to reflect its deeper thematic concerns. While I believe the same forces are at work in realist literature for children, the mortal shadow that hangs over literary childhood is thrown into particularly sharp relief in a fantasy context. My discussion is grounded in a series of close readings of primary texts, through which I hope to demonstrate the structural and definitive role of mortality. Chapter One examines some of the classics of nineteenth-century children's 
fantasy, exploring the dissonant forces at work in the way adults constructed childhood at the moment when fantasy, in particular, began in earnest to be addressed directly to children, and the ways those same forces shaped fantasy into the twentieth century. Chapter Two explores the construction of childhood through its metaphorical alignment with animals. Primacy is given in these stories to the intensely present and contextless vitality which both child and animal are invested. In Chapter Three, I consider the toy character (again closely aligned and identified with the child) as a lieu de mémoire, a site at which there is an intention to remember: toy and child in these narratives become both vehicles for, and objects of memory. Chapter Four looks at ghost stories in which childhood is figured as both haunted and haunting, memorialised even in its present tense. Chapters Five and Six move away from the child figure and its surrogates to consider how time and space are manipulated around child characters to reflect a construction of childhood invested with mortality. The time-slip fantasies of Chapter Five depict a connection between past and present which directly mirrors the relation of adult and child outside the text. In the alternate world fantasy of Chapter Six, space is manipulated around child characters to reflect literary childhood's ever-present sense of an ending; in these stories, the gap between adult and child (and the bridging of that gap) is expressed in spatial terms.

It is necessary in any consideration of children's literature (and particularly in a consideration of the gap that creates this literature) to account for connection as much as rupture. As crucial as the sense of rupture is in the conception of children's fantasy as intimation of mortality, it is just as important to note that mortality also arises out of the fundamental continuity of adult and child. Mortality is ultimately a shared condition, the great unifier: it joins beggar and king ("your worm," in Hamlet's famous phrase, "is your only emperor for diet"9); it also joins adult and child. Tim Morris points out this continuity in the adult-child relation as a counterweight to any formulation that reduces that relation to the question of colonising power: "in the case of 'the child,"' Morris writes, "the Other is Us.

\footnotetext{
${ }^{9}$ This phrase is found in Shakespeare's Hamlet Act IV, Scene 2, 11 20-21.
} 
Adults' ... identity is continuous with that of the children they once were" (You're Only Young Twice 10). Put another way, we were once them. They will be us. This continuity lies at the heart of the memento mori that so closely mirrors the adult-child relation: it depends for its entire effect on a confrontation with the fact that no one is exempt. It is paradoxical, but apt, given the various dissonant paradoxes at work in children's fantasy, that even as the mortality in children's fantasy arises directly out of the productive gap between adult and child, it is an equally strong expression of the kinship and continuity between them. 


\section{Chapter One}

\section{Wonderlands and Afterlives: Victorian Children's Fantasy}

Try and catch yesterday

Thackeray, "De Juventute"

In Father and Son (1907) Edmund Gosse tells the story of a very peculiar and particular Victorian childhood, and of the breaking down of a very peculiar and particular father-son relationship. Despite its peculiarity, however, Gosse's story dramatises and reflects many of the central concerns of the Victorian period in England: the excitement and agony of social and physical revolution and uncertainty; the erosion of religious faith; the inadequacy of tradition in the face of modernity. Gosse writes that his book is "the record of a struggle between two temperaments, two consciences and almost two epochs" (35). This division - Gosse's deep and painfully felt sense of rupture between himself and a father whose way of life (and way of thinking) "having passed away, will never return" (33) - is symptomatic of the age. Railways and cities were rapidly changing the physical and social face of the country, and the receding of holy authority upended the traditional religious foundations of social and individual identity: the ways of the father would no longer hold in the dynamic new world of the son. And Victorians were painfully aware of this. Indeed, as Robin Gilmour writes in The Novel in the Victorian Age, "[t]he only key to this period of unprecedented change is the fact of change itself, and the Victorians' consciousness of it" (2). Their consciousness is plain in the literature of the time. Matthew Arnold, for example, articulates a very Victorian state of mind in "Stanzas from the Grande Chartreuse" when he describes himself as "Wandering between two worlds, one dead / The other powerless to be born" (85-6). Thackeray's "De Juventute" is a movingly direct expression of his feeling both of being of two worlds, and of severance from the world that was:

We elderly people have lived in that prærailroad world which has passed into limbo and vanished from under us. I tell you it was firm under our feet once, and not long ago. They have raised those railroad embankments up and shut off the 
world that was behind them. Climb up that bank on which the irons are laid, and look to the other side - it is gone. There is no other side. (504)

More and more, Victorians came to frame their relationship with the past as loss and absence: the past has disappeared and passed away, it is gone; there is no other side. Victorians felt themselves, in a very acute way, to inhabit a period of transition. They lived, as it were, in the gap between the dying of the old ways and the coming of an unknowable and unpredictable new. This gap engendered the very characteristics that the period is known for: a dynamic energy and appetite for the new on the one hand, and a profound mourning for the lost and gone on the other.

It is little wonder, in this cultural context, that the child became the audience and object of a new, dedicated fantasy literature, a literature which sets the child apart as an object of contemplation and loss as much as it acknowledges community, and which rests, as Jacqueline Rose has famously stated, "so openly on an acknowledged difference, a rupture almost, between writer and addressee" (The Case of Peter Pan 1). Children's fantasy, which finds its origins as a distinct genre in this period, is both a product and a direct manifestation of the rupture that Victorians felt so profoundly - indeed, it is this same rupture that makes children's fantasy possible. It has shaped fantasy for children into the twentieth and twentyfirst centuries: lament, the sense of an ending with its attendant mortal notes, is built into the genre's very foundations.

Childhood became a potent locus of anxiety in the Victorian era as the symbol both of an irrecoverable past, and of an unknowable future: the contemplation of both from an unsettling and amorphous middle was the cultural work of the age. "It was in this period," as David Grylls writes, "that a regard for the young bit deeply into Western culture: when children figured frequently in articles and novels and [...] a swelling tide of attention rolled through every area of their lives" (Guardians and Angels 22-3). This is evident in Victorian literature for adults as well as for children; the sudden influx of child characters in the work of such writers as Dickens, Eliot, and the Brontës makes clear how central an enquiry the 
recent past of childhood memory became in the absence of larger structures of significance. David DeLaura calls this the "autobiographical impulse" of the Victorian era: "This presentation of one's own past as part of a search for new meanings in a deteriorating cultural situation is perhaps the most central binding activity of serious nineteenth-century literature. It is the great 'task', a kind of implicitly shared program for the century" ("The Allegory of Life" 338).

Children's literature (children's fantasy in particular) was a large part of this great task, and it moved into the mainstream. Some of the most influential writers and thinkers of the age tried their hand at writing for and of children, as part of a general cultural acknowledgement that "a children's book can be the perfect vehicle for an adult's most personal and private concerns" (Carpenter, Secret Gardens 37). Further, Victorian children's fantasy had a role in a larger cultural conversation about what childhood was, what it meant, and how adulthood stood in relation to it. There was a concomitant debate about what literature for children should be and do: all children's writers of the time took conscious and deliberate part in it. Children managed to be variously and simultaneously 'limbs of Satan', according to the Evangelical tradition, or 'little innocents' according to the Romantics (Inglis, The Promise of Happiness 70); these two conceptions of childhood jostled for dominance over the course of the nineteenth century.

The Victorian Golden Age of children's fantasy is commonly placed into a progressive narrative that sees the forces of imagination lifting children's literature out of the doldrums of the didactic and moral, freeing delight from instruction as the Romantic conception of childhood innocence triumphed over the Evangelical conception of Original Sin. John Rowe Townsend, in his history of English children's literature, Written for Children, titles his account of nineteenth-century fantasy "Imagination Rehabilitated":

In the early nineteenth century [...] imagination emerged from the long imprisonment it had suffered in the name of reason; and the old fairy tales [...] began to find their place in 'approved' children's literature. Their returning march 
was to continue all through the century; and they were joined by the modern fairy tale and fantasy. (67)

Both Roger Lancelyn Green and David Grylls treat Kenneth Grahame's The Golden Age (1895) as exemplar and culmination of this narrative, using Grahame's book (from which the Golden Age of children's literature takes its name) to make a larger point about the literary representation of childhood in this era. Green lays imagination's liberation squarely at the feet of the Romantic conception of childhood that The Golden Age presents and describes: Greene's work, he writes, is revolutionary "in its approach to childhood and its amazing understanding of the workings of the child's imagination and outlook. Hitherto the child had been pictured as an undeveloped adult, and all his books were intended in some degree to help force him into life's full flowering" (12). He continues: "The Golden Age [...] presented childhood as a thing in itself: a good thing, a joyous thing - a new world to be explored, a new species to be observed and described" (12), and Grylls agrees, calling the story "the conclusion to which the whole discovery of childhood had been tending: that the child's existence was important in itself, not simply as a preparation for maturity" (109).

Whether or not The Golden Age is taken to be the turning point these critics say it is, there are three important things to note about their formulation of childhood and its literary representation, which do apply more generally. The first is that the value in childhood what makes it "good" and "joyous" according to this line of thinking - is intimately linked to a Romantic conception of natural and essential innocence, the same innocence that James Kincaid has observed is essentially a negation: "The Romantic child was largely figured as an inversion of Enlightenment virtues and was thus strangely hollow right from the start: uncorrupted, unsophisticated, unenlightened" ("Dickens and the Construction of the Child" 32). Another is that this conception of childhood innocence is framed in terms of its effect on the adult writer: childhood is not to be felt, but to be "observed and described." And the last is that, in this formulation, where childhood is an end in itself rather than merely the means to something else, growing up amounts to a death - an ending rather than a beginning. 
Fantasy literature, in this narrative, acknowledges the special and virtuous difference of the child, and mirrors it in form: it lifts the child out of present circumstances and sets it down in a "new world," a Wonderland or a Neverland, the better to gaze at it with longing, to "fix [...] the child and hold it in place" (Rose 4). It is here that we find the basis for Peter Coveney's famous and widely-accepted charge against Victorian writers of the so-called "cult of childhood" of neurosis, regressive escapism, and overly sentimental nostalgia, as well as what he calls "the static and moribund child-figure of the popular Victorian imagination" (The Image of Childhood 33); it is here also that we find the ready explanation for what Judith Plotz calls the nineteenth century's "alien" preoccupation with childhood death, "less a destroyer than a strange preserver" ("Literary Ways of Killing a Child" 3).

It is not for nothing that such readings have held such critical sway for so long. There is indeed a strong Arcadian impulse (what Humphrey Carpenter calls "the search for a mysterious, elusive Good Place" (Secret Gardens 13)) in Victorian thinking about children and childhood that seems to be a clear reaction to the vicissitudes and anxieties of modernity, and this impulse is undoubtedly present in Victorian literature. There is also present (although far more in Victorian literature for adults rather than for children) what Judith Plotz calls "an obsessive nineteenth-century drive to contemplate images of a child stilled 'as if embalmed / By nature'" ("Literary Ways of Killing a Child" 2, quoting Wordsworth, Prelude 1805 399-400). But this argument, and the history of children's literature it attests to, need considerable revision and complication.

Childhood innocence, for one, was by no means an uncontested notion for Victorians - James Kincaid writes, accurately, that "we vastly overstate the dominance of this view of the child in the Victorian period" (Child-Loving: The Erotic Child and Victorian Culture 72). And far from being a simple endorsement of the innocent child in a pastoral arcadia far from the world, children's fantasy is one of the main arenas in which the dissonant tensions bound up in the child symbol are represented and worked out to complicated and ambivalent ends. Marah Gubar, while not denying the importance of the cult of childhood in understanding 
the children's literature of the time (the cult, as she writes, is "not a label critics have retroactively imposed on the past but rather a phrase the Victorians themselves invented to make sense of their own culture" (Artful Dodgers ix)), argues very persuasively for the need to reconceive both the cult of the child and Golden Age children's literature to take account of the complexities of Victorian attitudes:

many of the male and female artists who participated [in the cult of the child] were conflicted about how to conceive of children rather than fully committed to a particular ideal of innocence. Moreover, far from being oblivious to the possibility that adult fantasies about childhood might impinge on children, the Victorians and Edwardians frequently manifested a high level of critical self-consciousness about the whole problem of representing, writing for, looking at, interacting with, and worshipping children. (viii)

This very self-consciousness is an inevitable product of the very conscious and deliberate placement of the child at the centre of Victorian cultural discourse.

Secondly, instruction and delight mingle and commingle (and always have) in books for children in ways that belie the received progressive narrative of children's literature: this considerably complicates the vision of childhood they are said to represent. Even F.J. Harvey Darton, largely credited with originating the progressive narrative from didacticism to imagination in Children's Books in England: Five Centuries of Social Life (1932), is surprisingly equivocal about the boundaries between instruction and delight. While Darton defines children's books as "printed works produced ostensibly to give children spontaneous pleasure, and not primarily to teach them, nor solely to make them good, nor to keep them profitably quiet" (1), he also argues that the moral books of the Puritan Evangelical tradition fall under his definition:

It is only partly just to say that such works as [the highly evangelical James Janeway's Token for Children] are not "children's books". It is true that they do not provide "amusement", except unintentionally. But that is exactly why, at that 
time, they were "children's books". They were meant to give pleasure: the highest pleasure, that of studying and enjoying the Will of God. They were to be a natural happiness: no other happiness was conceivable. They were to be the recreation of leisure, not schoolbooks; nor did Janeway, or any other writer of the kind, separate the didactic or monitory-minatory element in them from the enjoyable. $\left(55^{-6)}\right.$

Darton calls this enjoyment "the secret spirit of all the Puritan books for children" (67). Further, books in the fantastic tradition are not free from instruction, nor do they deny the child characters inside them social and acculturated being - indeed, children's fantasy cannot help but acknowledge children as products of culture, and portray time, and change, and movement. If the fantasies of the Golden Age of children's literature can be characterised by anything, it is by tension over what the child is and what it means.

The genre's seemingly pervasive focus on mortality transcends this debate. For all that the traditional account puts the Victorian obsession with childhood death (and its literary representation) down to the urge to fix the child in essential Romantic purity, the sense of an ending in the genre is carried forward from the Evangelical tradition as well as the Romantic. The "limb of Satan" of the cautionary tale is as dead as the exemplary angel, after all. Mortality in children's literature, Victorian or otherwise, does not depend on an essentialised conception of childhood innocence, nor indeed does it depend on images of fixity or stasis. The teleological movement of Evangelical fiction, in which childhood is framed as little more than the road to adulthood, and life merely an inferior precursor to afterlife, springs from the same impulse as the Romantic yearning to stay or stop the child: both schools define childhood by its ending. The child figure in literature is necessarily retrospective; it is also, necessarily, a loaded symbol of time and time's inevitable passage. It represents, from an adult perspective, both the past (what is gone) and the future (what will no longer be), bound up into a fleeting present: thus mortality in children's literature is an inevitable consequence of writing to and of the child, an essential condition of its production. 
Romantic stasis and Evangelical movement are facets of the same preoccupation, and reach the same ends.

Charles Kingsley's The Water-Babies (1863) is a clear example of the way that mortality in children's fantasy manifests both through images of stasis and images of teleological movement. Ellie, the "little white lady," who is likened when we first see her "[u]nder the snow-white coverlet, upon the snow-white pillow" to a "wax doll" (The WaterBabies 57), is arrested in a perfect Romantic ideal which death preserves rather than destroying: "a clean white good little darling, as she always was, and always will be" (119). But Ellie is not the protagonist of this story. Rather, it tells the tale of Tom, a sweep living in sordid conditions in London, who falls into a stream and dies. Instead of being preserved in an angelic purity he does not possess, Tom transforms into a four-inch-long, gilled waterbaby, and moves at a breakneck pace through a watery, highly earthly paradise; he goes through a series of revolutions and evolutions before being reincarnated into a vibrantly alive man of Victorian industry. Tom is something of an object lesson in the danger and inaccuracy of putting the structural mortal notes at the heart of children's fantasy down to a Victorian urge to cast in amber and preserve.

The Water-Babies engages with the contemporary dialogue about childhood and children's literature in ambivalent ways that we should recognise as characteristic, even as Kingsley's narrator is nothing but declarative in tone. Kingsley seems to endorse the Romantic construction of childhood, and he uses fantasy to invest his instruction with delight: "Kingsley wanted to make morality and science and history and geography into an imaginative experience for children" (Leavis, "The Water-Babies" 156). But the form his narrative takes, with its intrusive, interrogative, avuncular narrator ("How do you know [there are no such things as water-babies]? Have you been there to see?" (77)), as well as its various kinds of moral and social commentary, owes much to the Evangelical school. Hence, perhaps, the surprising and un-foreshadowed jump from realism (the story of Tom's life as a sweep in the first chapter and a half) to fantasy (after his fall into the river and 
transformation); hence the intense realism (in terms of biology and natural history) of the fantasy world through which Tom moves as a water-baby. The Water-Babies is a text pulled in different directions, and by more than what Colin Manlove calls Kingsley's "weathercock habit" of managing to hold two dissonant ideas at two different moments with complete, if momentary, sincerity (Modern Fantasy: Five Studies 15).

The most important thematic tension in The Water-Babies is that between science and religious faith. Kingsley regarded nature as "the next greatest fact to that of God's existence, the fact by which we know Him" (Kingsley, Letters, 1113, italics in original); he saw the natural world as "the hieroglyphs of a divine script" (Kelly, "Introduction" 24). Kingsley called this philosophy "healthy materialism" (Letters, 113), and The Water-Babies is entirely shaped by Kingsley's "need to describe and demonstrate the presence of God and miracle in the world" (Manlove, "MacDonald and Kingsley: A Victorian Contrast" 140). "[T]he one true [...] doctrine," Kingsley tells us, "of this wonderful fairy tale [...] is that your soul makes your body, just as a snail makes his shell" (The Water-Babies 88). This somewhat idiosyncratic melding of the physical and the spiritual is at the heart of the way Kingsley constructs childhood and its setting.

For all that Kingsley quotes Wordsworth with overt approval at the beginning of chapters, the childhood of little Tom the chimney sweep is far from the Ode's "heaven-born freedom": Tom knows nothing of heaven ("He had never been taught to say his prayers. He never had heard of God, or of Christ ..." (The Water-Babies 44-5)), and he trails no clouds of glory. His life is mean, and small, and dirty ("there was no water up the court where he lived" (43)), and his existence is dominated by the joys and wants of the present moment, with little regard for the past, or real care for the future:

He cried half his time, and laughed the other half. He cried when he had to climb the dark flues, rubbing his poor knees and elbows raw; and when the soot got into his eyes, which it did every day in the week; and when his master beat him, which he did every day in the week; and when he had not enough to eat, which happened 
every day in the week likewise. And he laughed the other half of the day, when he was tossing halfpennies with the other boys, or playing leap-frog over the posts, or bowling stones at the horses' legs as they trotted by, which last was excellent fun, when there was a wall at hand behind which to hide. As for chimney-sweeping, and being hungry, and being beaten, he took all that for the way of the world, like the rain and snow and thunder, and stood manfully with his back to it till it was over, as his old donkey did to a hail-storm; and then shook his ears and was as jolly as ever. (44)

Tom's largely contextless orientation in the present moment, heedless of past and future (his dreams of "good times coming" when he becomes a man are based on the present behaviour of his master, Thomas Grimes, and no more) will become familiar in the chapter on animal stories, where the close association between the child and the animal character lies precisely in the intense and contextless vitality that is attributed to both animal and child. In the quote cited above, Tom is as an "old donkey in a hail-storm." Later, chased from Harthover House and pursued through the wood, across the moor, and down Lewthwaite crag, Tom is many different animals, depending on how he is making his way: ape, cat, fox, squirrel, Exmoor stag. This hunting, which ends in Tom's death, is an example of the subversion of the pastoral that is characteristic of animal stories for children. On the bank of the brook, feverish and sick, Tom says, "I will be a fish" (70), and dives under the water, where he becomes not a fish, but a water-baby: amphibious, miniature, and without memory, again adrift from context in time. The Fairy Queen, Mother Carey, tells us: "He is but a savage now, and like the beasts which perish; and from the beasts which perish he must learn" (70). The effect overall is to make Tom less than, or at least other than human. He is not a boy, but a sweep; not a boy, but an animal at bay; not a boy, but a water-baby. In the hand of Professor Ptthmllnspts, Tom is denied any existence at all. This is the child as Other, and the child as marginal. It is emphatically not the child as exalted. 
What Tom emphatically is, for the bulk of the narrative, is dead, in the midst of all his vitality. Even before his drowning, death imagery abounds: "He lay down on the grass till the beetles ran over him, and the flies settled on his nose" (67). The mixture of euphemism and gross realistic detail in the description of Tom's death - Kingsley's insistence on death, and his simultaneous skirting of it - is another example of the strange mixture of decisive surety and ambivalence that is so characteristic of his work.

There is much of the Victorian comfort book about Tom's death scene. We are told repeatedly that Tom's death is no tragedy at all, and that grief at his passing would be a mistake:

the keeper, and the groom, and Sir John made a great mistake, and were very unhappy (Sir John at least) without any reason, when they found a black thing in the water, and said it was Tom's body, and that he had been drowned. They were utterly mistaken. Tom was quite alive; and cleaner, and merrier, than he ever had been. The fairies had washed him, you see, in the swift river, so thoroughly, that not only his dirt, but his whole husk and shell had been washed quite off him, and the pretty little real Tom was washed out of the inside of it ...

His death is characterised as sleep - "and after that he dreamt of nothing at all" (72) - and we are reassured of his waking: "of course he woke - children always wake after they have slept exactly as long as is good for them" (76). This is not, however, an attempt, in Jacqueline Rose's terms, to fix the child in a prelapsarian, pre-linguistic state of innocence. For all that Kingsley acknowledges that Mrs Earth, " like many pretty people, [...] looked still prettier asleep than awake" (47), Tom's afterlife is far from restful, and is indeed characterised by forward motion, an implicit acknowledgement that the child cannot stay still, but inevitably grows. In all of the stories considered here, there is a close interrelation between mortality and the vitality that the child also embodies. One seems to call the other into being - death is elided with life in the construction of childhood precisely because childhood is eulogised even as its vitality is described. But this elision goes even further, and becomes a matter of 
linguistic necessity: "The problem raised by the acceptability of describing death is that the texts have no language in which to do so except the language of life" (Turner 77). Death is an absence that language cannot touch; Kingsley, in writing its presence, can only make it vital, and set it into motion.

The story equates stasis with regression (look at the example of the idle Doasyoulikes, or of Thomas Grimes, the Thomas that Tom would have grown up to be, had he lived, stuck fast in a chimney at the Other End of Nowhere), and Tom moves accordingly from stream to river to sea, and then to St Brandon's Isle, and on to the White Gates, and Peacepool, and the Other End of Nowhere at an ever-increasing pace: "Poor little fellow, it was a dreary journey for him; and more than once he longed to be back in Vendale, playing with the trout in the bright summer sun. But it could not be. What has been once can never come over again. And people can be little babies, even water-babies, only once in their lives" (113). This forward momentum, however, is not mirrored in Kingsley's narrative style, which frequently stops, digresses, circles around itself and starts again, as when his narrator spends two pages telling a story about the Mayor of Plymouth to 'explain' the stubborn latching on of lobsters.

Tom, on the other hand, must spend the story moving forward, evolving spiritually and physically. He gains memory and perspective, able to reach the Other End of Nowhere only by walking backwards and looking toward where he has been, mirroring the growing historical contextualisation of adulthood. He saves Grimes and is rewarded, not with Heaven and eternal rest with Ellie (whose status is even more ambivalent), but with the form of a very-much-alive Victorian gentleman of muscular Christianity and modern industry:

he is now a great man of science, and can plan railroads, and steam-engines, and electric telegraphs, and rifled guns, and so forth; and knows everything about everything [...]. And all this from what he learned when he was a water-baby, underneath the sea. (229-30)

In a book that has characterised the entire space of childhood as a form of afterlife, this transition to pre-life is disconcerting, even if in some ways it reinforces the afterlife as a 
metaphor for childhood as Tom grows out of it. Does Tom grow a new human body, to replace his old one? How does he go "home with Ellie on Sundays, and sometimes on weekdays, too" (229), if he is, indeed, alive? Is this strange reward (life as a man, rather than Heaven) a natural outcome of the evolutionary parable aspects of the story, of its insistence and founding notion that the soul makes the body? In any case, Tom's existence even as a man is still defined by inexorable forward motion: it is telling that the machines of his adulthood are railroads and engines and rifled guns - machines, in short, that propel.

Tom's perpetual motion contrasts with the stillnesses of the book, perhaps best exemplified by the marble stillness of Mother Carey in the Arctic, making things make themselves. She is described as a "peaked iceberg" (194), and "a white marble lady, sitting on a white marble throne" (195). Her lack of motion is insisted upon:

[Tom] expected, of course-like some grown people who ought to know better-to find her snipping, piecing, fitting, stitching, cobbling, basting, filing, planing, hammering, turning, polishing, moulding, measuring, chiselling, clipping, and so forth, as men do when they go to work to make anything. [...] But, instead of that, she sat quite still with her chin upon her hand, looking down into the sea with two great grand blue eyes, as blue as the sea itself. (195)

This stillness will be mirrored by George MacDonald's North Wind, sitting frozen at the border between life and death, but here it serves to underscore Tom's vitality, his refusal (and inability) to stay. As has been said, if any child is fixed in this story, it is Ellie. Where Tom's vitality transcends his death and transformation into a water-baby, Ellie fails to leave a mark on the world (note the pristine and untouched nature of her white room) even before she slips at the seaside and bashes her head open on a rock. Being the kind of child who does trail clouds of glory - she is "fresh out of heaven" (123) according to the narrator - she gains 
a pair of wings instead of gills after her death, and flies "out of the window, and over the land, and over the sea, and up through the clouds" (129).

Ellie's purity and good example is made much of in the narrative, but this is belied by the narrative's overall effect: she is a cipher next to Tom's vital energy; her lessons in goodness (we are given no detail of their content) pale next to the reader's vicarious experience of Tom's active and physical learning. The mere presence of both of these characters in the one story is enough to complicate the idea that death "fixes" the child, even for the Victorians.

George MacDonald's At the Back of the North Wind (1871) makes something of a pair with The Water-Babies. MacDonald's story organises itself around similar concepts of movement and stasis; it grapples with the same fundamental dissonances in the cultural construction of the child. In the story, a young boy named Diamond is chosen by the North Wind to be lifted up and away from his life in the first pages of the novel. Diamond sees the world with North Wind, he travels to the land at her back (a kind of ante-chamber to Heaven), he is given wisdom there, he returns to be God's instrument in Victorian London for a short time, and then North Wind takes him away forever. This short outline highlights what might be termed the Evangelical aspects of the book: it has much in common with the holy and exemplary childhood deaths of the Puritan tradition. But it is a rich and complex fantasy for all of that, marked by MacDonald's particular conception of the imagination, which he regarded as "that faculty in man which is likest to the prime operation of God, and has, therefore, been called the creative faculty, and its exercise creation" (A Dish of Orts n.p). Colin Manlove points out that MacDonald goes further even than this: "For him, the human imagination is not only like God, it is God working in man" (MacDonald and Kingsley 145).

Given this belief, it is little wonder that MacDonald uses fantasy to grapple with a God whose love can be cruel: "I won't believe it," Diamond tells the North Wind, after she 
warns him that she might be "cruel all through." "That would kill me. I love you, and you must love me, else how did I come to love you? How could you know how to put on such a beautiful face if you did not love me and the rest? No. You may sink as many ships as you like, and I won't say another word" (North Wind 94). The image of Diamond on the back of the North Wind comes directly, indeed, from Holy Writ: "Thou liftest me up to the wind; thou causest me to ride upon it, and dissolvest my substance" (King James Bible, Job 30.22). It is little wonder, too, that MacDonald uses fantasy to grapple with questions of life and death. Much like Kingsley, MacDonald complicates, and even disregards the boundary between fantasy and realism, instruction and delight, life and death; like Kingsley, he constructs death as "more life" (MacDonald, The Golden Key n.p), and this story about mortality is invested with a vital energy.

This may seem surprising in a book that is popularly known for its images of stasis. One such image is that of the North Wind herself, made into the physical threshold for the land at her back:

there the form sat, like one of the great figures at the door of an Egyptian temple, motionless, with drooping arms and head [...]. Her face was white as the snow, her eyes were blue as the air in the ice-cave, and her hair hung down straight, like icicles. She had on a greenish robe, like the colour in the hollows of a glacier seen from far off. (North Wind 121)

The resemblance to Mother Carey, the "white marble lady, sitting on a white marble throne" in Kingsley's Arctic Peacepool, is striking to say the least. A second image of stasis is that of Diamond himself, lying on his deathbed in the last pages of the novel: "A lovely figure, as white and almost as clear as alabaster" (North Wind 298). Young Diamond in this scene is perhaps the purest example to be found in Victorian children's fantasy of the "freezing, bleaching, washing, locking into fixity" that Judith Plotz sees as characteristic of Victorian literary representations of childhood death (Literary Ways of Killing a Child 3) - the very 
representations that Plotz calls "part of the enabling conditions for creating and recognizing children's literature" (4).

It is telling, then, that even this purest example fails to be quite pure. Diamond, for all that his name invokes the white, cold, and clear translucence of the gemstone, is named not for the stone, but for his father's favourite horse, himself named for the diamond on his forehead. This is an image of animal vitality if ever there was one. While he does not die until the very end of the book, there is an argument to be made that Diamond's time is up from the moment the North Wind first visits him in his hayloft, sending "a long whistling spear of cold" to strike his "naked little chest" (North Wind 50), and that the book tells of his various stages of afterlife. Like Tom's in The Water-Babies, Diamond's afterlife is characterised, above all else, by movement. Diamond is, like Tom, constantly in motion, and from his first meeting with the North Wind, he travels in ever-widening circles. His first journey takes him to the garden next door, his next over the streets of London, then over the coast at Kent, and finally to the North Pole and to the country at the North Wind's back. Like Tom, Diamond ranges farther and wider with one foot in the grave than life would ever have allowed him.

Even in the realist section of the story set in London, when the North Wind disappears for a long stretch of the narrative, At the Back of the North Wind relies on movement. Diamond travels to Sandwich, and then to London; later, he and his family relocate with their new employer to the employer's residence in Kent. This constant motion is reflected, in this section of the story, by Diamond himself, who wakes from his sojourn at the North Wind's back (a long tubercular illness) to find that his father's employer is ruined, and his family has fallen on hard times. Diamond takes up his work in these trying circumstances, and his days are a blur of motion. He traverses miles and miles on his father's cab while his father is unwell, he finds and saves street urchins Nanny and Crippled Jim from lives of want and deprivation, he takes care of his mother's new baby, he is the means of gaining both a second horse for the family and a new job as a coachman for his father. This constant movement is a representation of North Wind herself in her absence: when she 
appears in the story, she is a personification of elemental energy, which "twisted and shot and clashed and raved ten times more madly than anything else in creation except human passions" (North Wind 96).

It is worth asking, given the undeniable energies at work in At the Back of the North Wind, why the overall impression the story leaves is one of stillness. Perhaps it is because, for all of their inexorable motion, both North Wind and Diamond are most at their most striking and memorable becalmed in the images described above: North Wind sitting "with her face as white as the snow" at the doorway to her own country; Diamond lying "white and almost as clear as alabaster" on his deathbed. Perhaps it is because, for all that she is entirely composed of movement and vital breath, North Wind is also an explicit personification of death: "they have another name for me," she tells Diamond, "which they think the most dreadful of all" (North Wind 289). Having touched death and ridden on her back; having been, as the book so often repeats "to the back of the north wind," Diamond is a curiously passive creation, somehow sealed away from the business of living even as he takes part in it. He is held static in the eye of the North Wind's storm: "so sheltered [...] by North Wind's arm and bosom that only at times [...] did he recognize for a moment how wild the storm was in which he was carried, nestling in its very core and formative centre" (95-6).

Diamond, in his strangeness, speaks to the strange, dual construction of the child protagonist in this literature more generally: he is written both to represent childhood, and to transcend it: he is set apart, special, not representative at all. Here, crucially, it is Diamond's innocence that makes him an outlier. Diamond's untouched and untouchable nature reflects his position as exemplar: the narrative calls him "God's baby," and his main function in the plot is to be not a boy, but God's own instrument. In the chapter entitled "The Drunken Cabman," Diamond reforms the character of a poor alcoholic made abusive by drink with the power of his purity. It is as unsubtle an episode as a mallet falling from heaven: Diamond is described as an angel, both by the narrative ("The little boy was just as 
much one of God's messengers as if he had been an angel with a flaming sword, going out to fight the devil" (166-7)), and by the bemused cabman himself:

"Wife," said the cabman, turning towards the bed, "I do somehow believe that wur a angel just gone. Did you see him, wife? He warn't wery big, and he hadn't got none o' them wingses, you know. It wur one o' them baby-angels you sees on the gravestones, you know." (170)

Diamond's angelic function is only underscored by his early death. Once his family is ensconced in their new home, with Nanny, the former street urchin acting as nanny for the baby, his father hale and gainfully employed, and his mother taken care of, Diamond's earthly work is done. Not by accident is the family's new home (the end point of Diamond's incessant journeying) called "The Mound," as it will serve, in the end, as Diamond's grave. This is straight out of the Evangelical tradition - Diamond would not, indeed, be out of place in a puritan work like Janeway's 1671 Token for Children. ${ }^{10}$ More importantly, however, Diamond is an example of the way that the Evangelical and Romantic traditions collide in modern children's fantasy, leading to the peculiar (and contradictory) functions of the child protagonist described above. Child protagonists are always exemplars, whether in the Puritan tradition or not: they are always representative of childhood and emblematic of the cultural freight that is loaded onto the literary child figure. But child protagonists are also, by design, set apart from those around them and made singular and strange. So it is for Diamond, who is often too good, too knowing, too composed to be true: "If my reader find it hard to believe that Diamond should be so good," MacDonald's narrator tells us, "he must remember that he had been to the back of the north wind. [...] It was not in the least strange of Diamond to behave as he did; on the contrary, it was thoroughly sensible of him" (150).

It is made clear in the story that Diamond is what people used to call 'touched' - by the North Wind, by God, by madness - and this works to distance him from normal

\footnotetext{
${ }^{10}$ Janeway's Token is subtitled: "Being an Exact Account of the Conversion, Holy and Exemplary Lives, and Joyful Deaths of Several Young Children."
} 
childhood and from other children. Street-toughened Nanny thinks Diamond is soft-headed: "The cabbies call him God's baby [...]. He's not right in the head, you know. A tile loose" (172). Childhood, at least in the examples of Nanny and her friend Crippled Jim, is not particularly innocent, and Diamond is not quite a child. Moreover, even as Diamond's vision shapes the story (he has seen the back of the north wind, and sees life differently ever after), Diamond himself is overwhelmingly the object of vision: we are told of "the lovely stillness of the boy's face, with those blue eyes that seemed rather made for other people to look into rather than for himself to look out of" (276). He is not to be identified with, in other words, but to be observed and described. Diamond's overt status as the object rather than the subject of vision neatly makes a larger point about the child figure in children's literature and the effects of the gap between adult and child in its construction. This objectification is especially obvious in the early days of Victorian fantasy, when the boundaries of the genre (and the shape and function of the literary child symbol) were far from settled.

Diamond is a very Victorian creation in a very Victorian narrative. Working as both an every-boy and as a holy exemplar, in a narrative poised between Romantic delight and Evangelical instruction, fantasy and realism, movement and stasis, and indeed, the fleeting and the eternal, Diamond embodies the tensions at the heart of the child figure that the writers in the Victorian cult of the child were tasked to grapple with. The narrative, it seems, cannot help but construct Diamond as too good to be true in order to adore him; it also cannot help but acknowledge how thoroughly invented - how far from the lived experience of childhood - such a construction is. Diamond is a fantasy, a direct product of the Victorian era's unsettled middle ground.

Lewis Carroll's Alice (Alice in Wonderland (1865)) is perhaps the most famous and culturally tenacious fantasy of the Victorian period. As a literary figure, Alice has transcended her story, and is recognisable in contexts as diverse as a late 1980 os videogame 
series, or an episode of classic Star Trek. ${ }^{11}$ But the popular fantasy of Alice - the Alice of Carroll's prefatory poem to Wonderland, "All in a golden afternoon," as a "dream-child moving through a land / Of wonders wild and new" (21-3), is at a far remove from the Alice who appears in the text itself. The latter Alice actively refutes the "simple sorrows" and "simple joys" (Alice in Wonderland 111) of the innocent childhood of adult memory. ${ }^{12}$ On the contrary, Alice moves through Wonderland as a highly socialised being, "immersed," as Marah Gubar writes, "in discourse not of her own making" (Artful Dodgers 124). Alice is what Gubar calls a "drawing-room child, who has read and been taught 'all sorts of things'" (110), and Carroll's portrayal of her cannot help but acknowledge the ways in which she fails to be the dream-child of his fantasy, for all that she is the creation and object of adult longing. ${ }^{13}$ Like all of the Victorian works being considered, Alice in Wonderland demonstrates an open negotiation about what childhood is, and how adulthood constructs it.

It is illuminating to consider Alice in Wonderland alongside its front-matter - or, in other words, to compare Carroll writing about writing Alice as opposed to the writing the tale itself. "All in the golden afternoon" explicitly addresses the relation between adult, child, and tale:

\author{
Alice! A childish story take, \\ And with a gentle hand \\ Lay it where Childhood's dreams are twined \\ In Memory's mystic band, \\ Like pilgrim's withered wreath of flowers \\ Pluck'd in a far-off land. (lines 37-42)
}

\footnotetext{
${ }^{11}$ The videogame in which Alice appears is Megame Tensei, a 1987 game by Atlus in which she acts as both a foe and a usable demon. The episode of Star Trek is "Shore Leave" (1966).

12 The contrast between the front-matter and text of Alice in Wonderland also underscores the contrast between Lewis Carroll as literary persona, and Charles Lutwidge Dodgson as Oxford mathematician and scholar.

${ }^{13}$ C.L. Dodgson's particular relation to childhood (and to Alice Liddell, the muse and first recipient of his tale) is the focus of a great deal of academic scrutiny. Some important sources include Karoline Leach's In the Shadow of the Dreamchild: A New Understanding of Lewis Carroll (1999), U.C. Knoepflmacher's Ventures into Childland (1998), and Jackie Wullschläger's Inventing Wonderland (1995). Interesting complication and revision of Carroll's stance in relation to childhood is found particularly in the work of Marah Gubar and James Kincaid cited elsewhere in this thesis.
} 
This verse conceives of childhood as an object of nostalgic longing, distant and "far-off," even as a present Alice is invoked. The verse pictures the present child as haunted by a future in which her childhood is a thing of long ago: access to this childhood is granted by dream, memory, and story. In its evocation of memory, dream, and story, this prefatory poem recalls the last paragraph of Alice in Wonderland, in which Alice's grown sister sits on the riverbank looking at little Alice and contemplating Alice's future womanhood:

She pictured to herself how this same little sister of hers would, in the after-time, be herself a grown woman; [...] and how she would gather about her other little children and make their eyes bright and eager with many a strange tale, perhaps even with the dream of Wonderland of long ago; and how she would feel with all their simple sorrows, and find a pleasure in all their simple joys, remembering her own child-life, and the happy summer days. (111)

While Alice in Wonderland as a whole demonstrates Carroll's concern with dream and memory (Alice tries to recite from memory several times, and the entire adventure is framed as a dream on a riverbank) both the prefatory poem and the concluding paragraph form a sharp contrast with the matter of the tale itself, which eschews sentiment and tends to the ironic and sharply pointed. Martin Gardner calls Carroll's Alice visions "unrestrained [and] whimsically violent" (The Annotated Alice 9). Gubar characterises the relations in the Alice books as "reciprocal aggression," which "dwells on the difficulties that ensue when big and little creatures interact" (Artful Dodgers 111). This is far from the dream-child wandering "in friendly chat with bird and beast" ("All in the golden afternoon, line 24) that Carroll describes. Wonderland is indeed a land of wonder and subversion, but these qualities come in confusing and unfriendly forms, especially for the well brought-up, middle-class, quite prosaic Victorian child in the text; the child who wants to know the rules of the game so that she can win it, and is frustrated when there are none, or at least none that she can understand. 
Ultimately, indeed, it is Alice's frustration at Wonderland's brand of anarchy that gives her a way out of her own dream: her assertion that the players in the courtroom trial in the last chapter are "nothing but a pack of cards" (109) is a rejection of that world and its rules. She wakes up on her sister's lap by the riverbank with, one would imagine, a fair amount of relief. Dream and memory are shown to be uncertain friends, fickle and inaccurate: certain episodes in Wonderland have the quality of nightmare rather than of daydream, and Alice's memory, evidenced by her repeated attempts to recite, twists into strange shapes and fails her. For all of this, Alice trots inside a few lines later, "thinking while she ran, as well she might, what a wonderful dream it had been" (110). Alice in Wonderland is careful to insist on the ambivalence of wonder, on the way it melds fear and pleasure. But it certainly complicates the untrammelled joy of the projected future memory in the final paragraph, which functions more than anything as a demonstration of the gap between the remembering adult and the present child.

A reckoning with childhood from the adult writer's perspective must always be a reckoning with the eternal and the fleeting, with the way that time, in memory, both stretches out impossibly and has already passed in a flash. This has been reflected in the tension between movement and stasis: we find it in the ceaseless forward motion, wordy digressions, and icy stillnesses of Kingsley's Water-Babies; it is also found in the energy and force of MacDonald's north wind, set against the white figure who sleeps forever on the final page. Alice in Wonderland demonstrates this same tension, beginning, indeed, with Alice's strangely motionless descent down the rabbit hole, which is rather the opposite of a tumble: "Down, down, down. Would the fall never come to an end?" (10). She has time during this fall to examine a jar of marmalade, to ponder longitude and latitude, and to marshal questions about "the antipathies," where people walk with their heads downwards, and their feet up. Alice, for all that she fears "antipathies" does not "sound at all the right word" (11), is more right than she knows: Alice's relations with the creatures in Wonderland are marked by a peculiar kind of comic misunderstanding and contentiousness. Further, Wonderland is a 
topsy-turvy world, one in which the usual rules are warped and undermined, and nowhere is this more evident than in the way that Wonderland reshapes the passage of time.

The eternal and the fleeting are both present in the temporal construction of Wonderland, with characteristically Carrollian subversion. The White Rabbit is perpetually running for a missed deadline; the Mad Hatter, the March Hare and the Dormouse listlessly circle a table at which it is "always six o'clock" (64). This endless circling is due, according to the Hatter, to a quarrel with Old Father Time. The Hatter was reciting a verse at a concert given by the Queen of Hearts, "when the Queen bawled out 'He's murdering the time! Off with his head!'" (64). Since then, Hatter's penance has been, ironically enough, to sit at table killing time. This stasis is contrasted with the rollicking pace of the narrative, as Alice passes from adventure to adventure with hardly a pause for breath; it is also contrasted with Alice, asleep on the riverbank in the frame of the story. At other moments, like the Caucus race in chapter three, Alice rushes to stay in the same place, combining the fleeting with a particular endless futility that is, again, distinctively Carrollian.

It is Alice herself, prim and goal-focused ("and now for the garden!" she cries, having been waylaid by one of Wonderland's startling changes of scale (20)), who disrupts Wonderland's strange temporality most directly, drawing explicit attention to the ways that Carroll's fantasy realm distorts time's working. This is, paradoxically, both Carroll's greatest subversion and the closest link of Alice to other Victorian fantasy: that it is the child character who challenges the iterative or circular time which so often characterises literary childhood (Nikolajeva, From Mythic to Linear 5); that it is Alice who, as James Kincaid writes, "often upsets a beautiful comic game by introducing the alien concept of linear progression to infinity" (Alice's Invasion of Wonderland 92). Kincaid points out elsewhere that "things do not conclude in Wonderland" (Child-Loving 293), and that it is Alice who tries to drive things towards conclusion. She disrupts the suspension of disbelief involved in the image of the Hatter and the March Hare endlessly revolving around the table for clean crockery by asking "what happens when you come to the beginning again?" (64). Upon 
understanding that the Mock Turtle's lessons (ten hours one day, nine the next, and so on) come to a holiday on the eleventh day, Alice asks eagerly "and how did you manage on the twelfth?" (87). The subject is quickly changed in both instances. A reckoning with time, as Alice demonstrates, must always be a reckoning with endings, and it is the child, loaded with heavy and dissonant symbolism, who drives the issue to a head.

But Alice in Wonderland shows its concern with endings in more ways than its manipulation of time. This preoccupation also manifests itself in Wonderland's chaotic mutability, and in its contemplation of death as an object of black humour. "That the Alice books should consist, in their deepest level, of an exploration of violence, death and Nothingness," writes Humphrey Carpenter, "is not in itself surprising. Comedy tends in that direction" (Secret Gardens 62). Indeed, the death jokes begin even before Alice enters Wonderland proper, when, during her strangely static descent down the rabbit hole, she remarks that "after such a fall as this [...] I wouldn't say anything about it, even if I fell off the top of the house!" The narrator pauses to add a dry-as-dust parenthesis: "(which was very likely true)" (10). There are numerous points in the Alice books where annihilation is an overt theme. Many of the most famous examples, such as the Red King's dream, and the fate of the baby oysters in "The Walrus and the Carpenter" are found in Through The Looking Glass (1871), which, written some years after Wonderland, is quite different from it sadder, more distant, and generally more contemplative in tone. Even in Wonderland, however, death remains on or near the surface. In the hall of doorways, Alice begins to shrink in one of the startling changes in size (and therefore aspect - it is after all, forced growth and forced regression, change writ large) that she undergoes during the story. Realising, we are told, that it is the fan she is holding that is making her shrink, "she dropped it hastily, just in time to save herself from shrinking away altogether. "That was a narrow escape!' said Alice, a good deal frightened at the sudden change, but very glad to find herself still in existence" (20). 
Mortal threat abounds in Wonderland, even apart from the shockingly random danger of blithely touching something that can wink you out of existence. Wonderland's inhabitants are a particularly bloodthirsty lot. For all that mortal danger in Wonderland is blunted by its peculiar brand of absurd everlastingness - in which the Queen of Hearts can threaten all and sundry with execution and the Gryphon can assert that "it's all her fancy, that: they never executes nobody" (83) - death is a game that all the Wonderland creatures play. Alice and the Duchess must duck potentially lethal flying kitchenware, and both the trial of the Knave and the trial in "The Mouse's Tail" are potential death sentences: one through the potentially lethal anger of the Queen of Hearts, and the other through the machinations of "cunning old Fury," who will "try the whole cause and condemn you to death" (28). Both the mouse and the Knave escape the axe, but their escape is as maddeningly arbitrary as the danger was in the first place. At all times, death is held at arm's length with a brittle, superficial wit.

Further, Wonderland is heavily populated by animals or animal hybrids, and mortal threat in Wonderland is also present in the characteristically animal instinct towards predation, particularly predation linked to eating. In the pool of tears in chapter two (this pool is itself a manifestation of grief, linked both to the tears of the baby that becomes a pig, or potential pork, and to the wailing of the mock turtle, who is animated food, rather than a real animal), Alice drives away the birds around her by praising the hunting skills of her cat, their natural enemy. The nursery verses that represent Alice's moral instruction twist, outside of her conscious control, into stories of things that eat and are eaten: the little busy bee, meant to promote the value of hard work and industry, becomes a lazy crocodile, welcoming "little fishes in / With gently smiling jaws" (19). "I passed by his garden" becomes the story of an owl and a panther at table eating a pie. This story ends as one would expect, somehow more horrible for being so carefully elided, effectively forcing the reader to write the cruel ending:

When the pie was all finished, the Owl, as a boon, Was kindly permitted to pocket the spoon: 
While the Panther received knife and fork with a growl, And concluded the banquet by - (94)

In chapter five, "Advice from a Caterpillar," Alice herself becomes predator: with a neck that reaches beyond the treetops, she is mistaken for a Serpent by a pigeon defending the eggs in her nest. As James Kincaid points out in "Alice's Invasion of Wonderland," the pigeon refutes Alice's denial of being a Serpent by applying "the only test that matters" (92): "I suppose you'll be telling me next that you never tasted an egg!" (48). Alice, as a well-bred, middle-class Victorian little girl can only fail this test, and logic is (again, in a distinctively Carrollian way) driven to a ruthless, illogical end. At the Mad Hatter's tea party, Alice's first question, on hearing a story about three sisters who live down a well, concerns food: "'What did they live on?' said Alice, who always took a great interest in questions of eating and drinking" (65). It is a common point that food and eating replaces sexuality in children's stories as evocative of physicality and sensuality, of the life of the body. Alice's (childish) interest in food places her squarely alongside the animals who surround her, ruled as they are by "questions of eating and drinking."

Even filled with death jokes, violence, and a keen awareness of annihilation, Alice in Wonderland is a book that is ultimately characterised by an abundantly vital kind of energy. Pots, pepper and pig-babies are flung through the air; Father William turns a backsomersault in his doorway; the White Rabbit endlessly chases the clock. And it is this energy that separates Alice in Wonderland from Carroll's second Alice book, Through the LookingGlass and What Alice Found There (1871). In Looking-Glass, Tweedledum and Tweedledee fail to get around to having their battle, for all that time they spend preparing for it (instead they sit and tell the story of the Walrus and the Carpenter); the battle between the Lion and the Unicorn happens off-screen, as it were: by the time we meet them, they have paused for tea, and sat down to talk. Looking-Glass is, perhaps above all, a story of creatures who pause their various actions to sit down and talk. 
The Alice books are often conflated and treated as one work: critics like Humphrey Carpenter discuss them in tandem, and film adaptations (most notably the Disney adaptation of 1953) tend to place episodes from Looking-Glass alongside those from Wonderland without differentiating between them. It is true that the two books are a set, and that they share certain characteristics and themes. They both have Alice as a protagonist; both maintain a tightly controlled and organised, highly logical insanity; both are concerned with eating, and with death. But Looking-Glass has a dramatically different tone. Where in Wonderland, for example, creatures are obsessed with eating, in LookingGlass they pause to contemplate not eating. In chapter three, entitled "Looking-Glass Insects," Alice and the mournful Gnat discuss the eating habits of insects that (like the Mock Turtle) are themselves food:

"Crawling at your feet," said the Gnat [...], you may observe a Bread-and-butterfly. Its wings are thin slices of bread-and-butter, its body is a crust, and its head is a lump of sugar."

"And what does it live on?"

"Weak tea with cream in it."

A new difficulty came into Alice's head. "Supposing it couldn't find any?" she suggested.

"Then it would die, of course."

"But that must happen very often," Alice remarked thoughtfully.

"It always happens," said the Gnat.

After this, Alice was silent for a minute or two, pondering. (154)

This exchange is foreign to the splintery energy of the first book, despite its obsessive focus on the question of what one lives on. Alice's direct and thoughtful confrontation with the idea of death, and the silence this confrontation engenders (she is "silent for a minute or two," and the reader is given no insight into her pondering) are the most important tonal 
shifts. Later, in conversation with the White Queen, Alice cries with loneliness and is instructed to hold off her tears by "considering":

"Consider what a great girl you are. Consider what a long way you've come today. Consider what o'clock it is. Consider anything, only don't cry!"

Alice could not help laughing at this, even in the midst of her tears. "Can you keep from crying by considering things?" she asked.

"That's the way it's done," the Queen said with great decision ... (177)

Keeping from crying by considering things - and laughing in the midst of tears - might fairly describe of the entire action of Through the Looking-Glass, as well as the impulse that drives its composition.

The quite dramatic change in tone in Looking-Glass is in large part a reflection of the gap between it and Wonderland. Looking-Glass was published in 1871, a space of years after Wonderland in 1865 - indeed it is the beginning of the "after-time" of Wonderland's final paragraph - and the increased distance of the author from the presentness of the child who inspired his work is made painfully evident. Alice in Looking-Glass is what Nina Auerbach calls a "pale, attenuated presence" (Romantic Imprisonment 132) compared to the child in Wonderland. In the poem that prefaces Looking-Glass ("Child of the pure unclouded brow"), Carroll calls both himself and his dream-child "older children ... / Who fret to find our bedtime near" (23-4). Wonderland is called "a tale begun in other days" (13), and it is contrasted with the present tale, in which:

the shadow of a sigh

May tremble through the story

For happy summer days gone by

And vanish'd summer glory. (lines 31-4)

Through the Looking-Glass begins, in direct contrast to the "happy summer days" of Wonderland, on a winter scene. Alice, curled up in an armchair, remarks on the sound of the snow against the windows (a direct link to the "shadow of a sigh" in Carroll's poem): "How 
nice and soft it sounds!" (126). In Looking-Glass, this "shadow of a sigh" also manifests in Alice's increased passivity, in the increased tension between Alice as subject and Alice as object of her adventure. Where Wonderland is framed as Alice's dream, the question is complicated in Looking-Glass by the sleeping Red King:

"He's dreaming now," said Tweedledee: "and what do you think he's dreaming about?"

Alice said "Nobody can guess that."

"Why, about you!" Tweedledee exclaimed. [...]

"If that there King was to wake," added Tweedledum, "you'd go out-bang!-just like a candle." (167-8)

Existential alarm seems a very strong term to apply to the uncertainty at the centre of this passage, but no less apt for that. It adds an ironic consequence to the entire notion of a "dream-child," one with the threat of extinction at its centre. The vital question on the final page of the story, about who is responsible for dreaming the story and the girl inside it, Alice or the Red King, remains unanswered and unanswerable. In the final line, this question is aimed directly at the reader: "Which do you think it was?" (244).

The Looking-Glass creatures, moreover, force Alice into passivity. Where Alice in Wonderland recites, Alice in Looking-Glass is recited at: she spends a good deal of the story as an unfailingly polite, but often bored and reluctant audience. The mournful jokes of the Gnat ("'You shouldn't make jokes,' Alice said, 'if it makes you so unhappy" (152)), the wordplay of Humpty Dumpty ('"Is that all?' Alice timidly asked" (196)), the ballad of the hapless White Knight, and the poetry of Tweedledum and Tweedledee -

Here Alice ventured to interrupt him. "If it's very long," she said, as politely as she could, "would you please tell me first which road-"

Tweedledee smiled gently, and began again ... (161-2) - are just a few of the performances that Alice is forced, against her will, to sit through in her race to reach the Eighth Square and become a queen. Alice wants to move forward, and she is 
frustrated when every creature she encounters pauses to sit down and talk. The entire book seems to be pointing a gentle, mocking finger at the entire enterprise, first of trying to hold the child still, and then of imagining the child to be a rapt audience for "an adult's most personal and private concerns" (Carpenter, Secret Gardens 37).

Like the Gnat who cries at his own jokes and comments quite overtly on Carroll's method of holding despair at bay with bright, sharp-edged humour, and the Red King dreaming the girl into being, the White Knight, kind and pitiable and pathetically inept, is a Nonsensical version of Carroll himself. ${ }^{14}$ Unable to stay on his own horse for two minutes together, or to keep himself oriented facing forward, the White Knight comes upon Alice and makes her the audience for an unburdening of emotion that has far more to do with his desire than hers. He wants to cry, and he wants to make Alice cry with him: it is no accident that his ballad, of "the aged aged man" and of "that summer evening long ago" filches its tune (as Alice herself points out in the text) from Thomas Moore's aptly named "I give thee all, I can no more." Alice remains, as ever, polite, befuddled, and more than a little bored. She is all too aware both of the Knight's ridiculousness, and of his kindness, but is unable to quite be moved: "she stood and listened very attentively, but no tears came to her eyes" (219). The knight then manufactures his own emotional leave-taking. There is both humour and actual pathos in his orientation towards the past (facing, as he does, backwards on his horse), in contrast with Alice's future focus:

"But you'll stay and see me off first?' he added as Alice turned with an eager look in the direction to which he pointed. "I shan't be long. You'll wait and wave your handkerchief when I get to that turn in the road? I think it'll encourage me, you see."

"Of course I'll wait," said Alice: "and thank you very much for coming so far-and for the song-I liked it very much."

\footnotetext{
${ }^{14}$ Critics who have drawn a direct link between Carroll (or indeed, Charles Dodgson) and the White Knight include Martin Gardner in The Annotated Alice (1960), and Donald Rackin, in "Love and Death in Carroll's Alices" (1982). Considering the Knight as a Carrollian self-portrait is a common critical inference: Alexander L. Taylor's 1953 biography of Dodgson is entitled The White Knight: A Study of C.L. Dodgson.
} 
"I hope so," the Knight said doubtfully: "but you didn't cry so much as I thought you would." (222)

Alice is not unsympathetic, and she dutifully waves her hanky, but she is also more than ready to move on: "'I hope it encouraged him,' she said, as she turned to run down the hill: 'and now for the last brook, and to be a Queen! How grand it sounds!' A very few steps brought her to the edge of the brook. 'The Eighth Square at last!' she cried as she bounded across" (222-3).

Alice's drive to move forward against those Looking-Glass creatures who desire to hold her still recalls both the linearity she injected (however stuffily and politely) into the circularity of Wonderland, and the tension between stasis and movement that is so prevalent in Victorian children's fantasy as a whole. Thus Alice remains a child of seven, despite the fact that Dinah has had kittens (introducing a generational shift into the narrative), and despite the years that separate Alice's adventure in Wonderland from her adventure through the Looking-Glass. Looking-Glass is, like Wonderland before it, a tale of tension between inexorable movement - Alice's movement towards queenhood, for example, or the larger movement in the story towards "death and Nothingness," the feared "bedtime" of Carroll's prefatory poem - and a longing for stasis and stillness. This stillness is, in the opening of Looking-Glass, tied to the sigh of the snow, and the way Alice imagines the snow covering the trees and the fields snugly - "you know, with a white quilt" (Looking-Glass 126). There is a certain desire invested in this image of sleep, both for the repose of winter, and for the fullness of summer; there is also the shadow, as Carroll says in the prefatory poem, of summers gone and never returning, and of a sleep longer than winter.

Alice's reign as queen in the Looking-Glass chess game does not bring her power, nor any particular change in status. Having reached the Eighth Square, Alice is quizzed in mathematics, slept on, recited at some more, and finally joins a feast where the guests become the food, at which point she shakes herself back into her armchair on the original side of the looking-glass. This abiding contrast - the contrast between Alice's desire for 
forward momentum and the other characters' desire for her to stop and stay and listen speaks directly to Carroll's position as the author of a book for children ("... time [is] fleet and I and thou / Are half a life asunder" (lines 3-4)) and the fleeting childhood he addresses. It also demonstrates a relation between adulthood and childhood that was particularly pertinent to Victorians; one that children's literature continues to define itself against. 


\section{Chapter Two}

\section{Instinct and Appetite: Animal Stories}

There is ample evidence in the first Victorian fantasies of childhood of how closely the child and the animal are aligned in children's books. There is Tom, the water-baby, moving back up the evolutionary chain towards personhood, and both Alice in Wonderland and Through the Looking-Glass are filled with animal characters. Wonderland begins, after all, with a rabbit attempting to outrun his pocket watch, and Looking-Glass ends with a "provoking kitten" ignoring Alice's question of who dreamed it all. In between these two points, Alice encounters a myriad of creatures, and those encounters are marked by comic miscommunication that ranges from the mildly baffling to the violent. William Empson, famously, has argued in detail that Carroll's Alice books demonstrate "a shift onto the child [...] of the obscure tradition of pastoral" (203). This is a pastoral that both draws on and grapples with the Romantic image of childhood as "not yet [...] put wrong by civilization" (Empson 208). The close association and identification of animal and child in children's books, which is, as David Rudd writes, "so common that it is easy to forget the figurative nature of this alliance" ("Animal and Object Stories" 242), is a representation both of the way that the child is constructed as "natural," and of the tensions and ambivalences contained in that natural construction. The animal-child relation, indeed, is at the heart of the pastoral of childhood.

John David Moore has pointed out how closely cultural constructions of childhood align with the pastoral:

Children and childhood have been endemic to pastoral from the beginning; children's literature merely aligns it with elements that had been there from the start. [...] Arcadia or the Golden Age is the mythohistorical childhood of the race. 
The Romantic child of nature is, after all, an object of memory; it is a manifestation of "the wonder and desire adults invested in trying to remember their past, unsocialized selves" (Austin 76). It has no existence except set against a present self that is constructed as less natural, less authentic, and is, crucially, mourned. This is a distinctly pastoral construction. Peter Marinelli calls the pastoral "the art of the backward glance" (8), and characterises it as necessarily retrospective, necessarily elegiac, and dependent on present loss or lack. Raymond Williams's The Country and the City devotes a chapter to pastoral's "problem of perspective," outlining the way that successive generations of writers mourn a succession of infinitely recessive Old Englands, whose 'natural' way of life is always located in the childhoods of their authors, and always either in the process of dying or only recently dead. This distance between the writer and the threatened way of life being described (the distance, indeed, between the adult and the child the adult used to be) is central to the pastoral, and it is in this distance that children's literature, with the gap between adult and child at its heart, mirrors the circumstances of older pastoral conventions. "[C]hildhood, like Arcadia," John David Moore writes, "must be left to be truly appreciated. The child, the shepherd, the peasant, all finally live in ignorance of their Arcadian bliss. [...] The country only becomes pastoral when entered from the city, and childhood becomes Arcadian only when recaptured in adulthood" (47). The Golden Age can only ever be recognised, in other words, retrospectively, from the Age of Iron. The pastoral, like the literary depiction of childhood with which it is so tightly bound, depends on an ending.

With all of this in mind, the episode in Lewis Carroll's Through the Looking-Glass when Alice walks through a wood with a Fawn is even more striking in its contrast with all of her other, far more fraught and contested interactions in Carroll's dream worlds. For the space of half a sentence, Alice and the Fawn are allowed a perfect communion:

So they walked on together through the wood, Alice with her arms clasped lovingly round the soft neck of the Fawn, until they came out into another open field, and 
here the Fawn gave a sudden bound into the air, and shook itself free from Alice's arm. (157)

Their fragile partnership depends entirely for its existence on the wood they walk through, in which they are allowed to be free of memory and self-consciousness. It fractures as soon as they step out of the wood "where things have no names" (155), and remember themselves:

"I'm a Fawn!" it cried out in a voice of delight. "And, dear me! You're a human child!" A sudden look of alarm came into its beautiful brown eyes, and in another moment it had darted away at full speed. (157)

This fleeting moment of "loving" connection is as close as Carroll ever comes to depicting the Romantic identification of animal and child that was so prevalent in Victorian culture at large. It is quickly forsaken in favour of the child as social and cultural agent: even as the Fawn bounds away from her and from the wood of forgetting, Alice finds solace in her own self-possession:

Alice stood looking after it, almost ready to cry at having lost her dear little fellowtraveller so suddenly. "However, I know my name now," she said: "that's some consolation." (157)

This is the Fall - the experience of Eden, the dawning of knowledge of good and evil (or of knowledge at all), and the consequent expulsion from Paradise - over the space of six sentences. Robert Pattison makes the point, in his history of the child figure in Western literature, that the close association of child and animal predates the Romantic child, children's literature, and indeed the literary child altogether: in the ancient world children were not considered fit subjects for literature precisely because they were considered akin to animals - subhuman, sub-rational, and incapable of moral action (The Child Figure in English Literature 1-3). He quotes Aristotle's Ethics: "Both children and the lower animals share in voluntary action but not in choice" (Pattison 1). When children do begin to be represented in literature, Pattison argues, they are intimately linked to the theme of moral, 
ethical, and rational being. He notes "the frequency with which children appear in literary surroundings which discuss Man's fallen nature" (x). As we have seen in the origins of Victorian fantasy, the Fall, and how to conceive of the child in relation to it, are central to children's literature, whether the child is, on the one hand, inheritor and manifestation of Original Sin, or on the other, an embodiment of the pure innocence from which adulthood has fallen.

The child-animal relation speaks directly to this very question in both the Puritan and the Romantic traditions: animal stories for children reveal the complicated relationship of the innocent to the bestial, of the pure to the savage. That the child-figure embodies all of these tensions is made more than clear in Carroll's Alice, the drawing-room child, whose interactions with the creatures of Wonderland and Looking-Glass land constitute contests of power (most often determined by size), and who can only be a Romantic child of nature (and walk in communion with a Fawn) when she has lost any sense of herself as a child at all.

It is characteristic of Carroll that his most straightforward invocation of pastoral imagery serves simultaneously as his most straightforward denial of the traditional Romantic pastoral of childhood. But Carroll is no outlier in his ambivalence regarding the natural world and the child's relation to it: ambivalence is built into the pastoral as a form. It is this very ambivalence, along with the pastoral's inherent retrospectivity, that makes literary childhood so powerful an iteration of the pastoral. Williams notes the tendency, beginning in the Renaissance, to extract only the "invocations of summer" from classical pastoral: "At a very much later date, this could be seen, by false extraction, as the essence, the only essence, of pastoral" (The Country and the City 16). "Wolves, foxes, locusts, and beetles," he writes in counterpoint, "are as much a part of the experience as balm and rockrose and apples and honey" (15). A similar ambivalence is encoded in the animal as a literary symbol, and thus in the child with whom the animal is so closely associated. As Martin Danahay points out, "a fundamental symbolic violence [...] is repressed and marginalised but underscores all representations of animals" ("Nature Red in Hoof and Paw" 
102). Unsullied by civilisation, the animal-child is also unconstrained by it: an eruption of brutality is always possible. An animal, according to the Oxford English Dictionary, is "a living organism which feeds on organic matter" - put another way, it is a living thing that eats - and Carroll's Wonderland is very much of the pastoral tradition, as well as very much of its time, in the Darwinian predation that abounds, and in its focus on questions of eating and being eaten. ${ }^{15}$

Hunger and its sating are central to Rudyard Kipling's Jungle Books (1893 and 1895), and the Jungle Books are of a piece with the rest of the animal stories considered here in casting the shadow of death quite explicitly over the scene of childhood. Here, it is managed simply by virtue of its setting as jungle, a place where the stakes are always life or death. Death is normalised, and tied to eating ("[Mowgli] loved better than anything else to go with Bagheera into the dark warm heart of the forest, to sleep all through the drowsy day, and at night to see how Bagheera did his killing. Bagheera killed left and right as he felt hungry, and so did Mowgli..." ("Mowgli's Brothers," Jungle Book 25-26)), but also to revenge, in the killing of Shere Khan the tiger. Vitality is brought into sharp relief by its potentially violent fleetingness; the refrain of the Chil the Kite, carrion bird of the Indian jungle ("Here is the end of every trail") speaks to inevitable conclusions. The last line of Chil's Song is the Law of the Jungle in summary: "Here is the end of every trail - and now my hosts are fed" ("Chil's Song," Second Jungle Book 260).

Beyond the new and destabilising vision of nature as amoral and, in Tennyson's famous phrase, "red in tooth and claw" ("In Memoriam" 56.15), Darwinian science upended Victorian certainties by questioning the boundary between the human and the animal. This remains a somewhat fraught question - the Oxford English Dictionary, for example, makes a point of including humanity in its definition, stating that an animal is "any living creature, including man." That humans are included in the phrase "any living creature" does not,

\footnotetext{
${ }^{15}$ Rose Lovell-Smith's "The Animals of Wonderland" provides a reading of the Alice books that explores the texts in light of contemporary discourses of natural history, particularly the Darwinian narratives of struggle, predation, and amorality.
} 
evidently, go without saying. Harriet Ritvo claims that this insistent and persistent need to assert that people are animals "signals a context of semantic and cultural tensions" ("Animal Dreams and Animal Reflections" 271). It is precisely these tensions - between Romantic purity of origin on one side and pre-rational savagery on the other - that play themselves out in animal stories for children, in the Victorian period and beyond.

The Jungle Books hinge on anxiety about the uncertain boundary between human and animal, and Mowgli, Kipling's Jungle boy, straddles this boundary in unclear and internally contradictory ways. Tess Cosslett observes that "[t]hrough the presence of the wild child Mowgli, [Kipling] brings into question the interconnected relations between the animal and the human, the child and the adult" (Talking Animals 124). Mowgli, as "a naked brown baby who could just walk" ("Mowgli's Brothers," Jungle Book 10), raised by wolves among the Seeonee Pack, embodies the strange hybridity of the child who is and is not animal. Kipling makes clear that the sort of boundary-crossing Mowgli enacts is only possible because he is a child, and has a child's innocent and fearless unconcern. ${ }^{16}$ In "Mowgli's Brothers," for example, after toddling into the wolves' den, Mowgli laughs in Father Wolf's face. Mother Wolf keeps him because she admires his boldness: "He came naked, by night, alone and very hungry; yet he was not afraid! Look, he has pushed one of my babes to one side already. [...] Keep him? Assuredly I will keep him" (15). This is a fearlessness linked to lack of experience and a natural affinity with nature. But even as Mowgli is a child, akin to animals (and perhaps animal himself) who must (like Kingsley's Tom in The Water-Babies) grow and be educated to humanness, he is also - in Kipling's uncomfortably colonial terminology - innately Man, born to power:

"But why-but why should any wish to kill me?" said Mowgli.

"Look at me," said Bagheera. And Mowgli looked at him steadily between the eyes. The big panther turned his head away in half a minute.

\footnotetext{
${ }^{16}$ In his boundary-crossing, Mowgli is very like Kim, Kipling's other great boy-protagonist. The parallels between Mowgli's movement between Jungle and village and Kim's between races and castes in the Great Game of Empire, makes clear how important imperial discourse is in Kipling's work overall.
} 
"That is why," he said, shifting his paw on the leaves. "Not even I can look thee between the eyes, and I was born among men, and I love thee, Little Brother. The others they hate thee because their eyes cannot meet thine; [...] because thou art a man." ("Mowgli's Brothers," Jungle Book 29-30)

Mowgli's ambivalent (and isolating) status is characteristic of The Jungle Books, and of children's animal stories in general: child characters who are aligned with animals in these stories are always both animal and not, set apart from both animal and human society, oddly alone.

There is also a paradoxical duality in Kipling's portrayal of Mowgli's education. Mowgli grows in the Jungle, and is educated in its ways and Law. His education, provided by the wise Baloo, owes much to Rousseau's theories of the 'natural' child: "And he grew and grew strong as a boy must grow who does not know that he is learning any lessons, and who has nothing in the world to think of except things to eat" ("Mowgli's Brothers" 26). The concept of natural education finds its origin in Rousseau's Emile, a 1762 treatise in which Rousseau details his theories both of the innate goodness of the 'natural' individual, and of how to educate such an individual to resist the corrupting nature of society. As Sally Shuttleworth helpfully summarises, Rousseau argued that the child should not be treated as if it were a creature of reason; that the child should "be raised according to the laws of development laid down by nature"; that childhood is separate, "a space and time that was not adult; and that this state should be prolonged as far as possible" (The Mind of the Child 5).

This construction was not uncontested even in its own time - Mary Wollstonecraft, for example, wrote a children's book directly engaging with and contradicting Rousseau's theories at least as they applied to the education of girls, ${ }^{17}$ and there is an entire tradition of women children's writers in the eighteenth and nineteenth centuries, including Wollstonecraft, Maria Edgeworth, Mrs Molesworth, and Juliana Ewing, whose focus is on depicting the social and socialised child. As we have seen already in the work of the Victorian

\footnotetext{
${ }^{17}$ Namely, Original Stories from Real Life; with Conversations Calculated to Regulate the Affections, and Form the Mind to Truth and Goodness (1788).
} 
fantasists, the concept of the natural child is not so much endorsed in children's books as wrestled with, modified, and found in various ways to be lacking or incomplete. Similarly, while the Rousseauian 'natural child' is at the foundation of animal fantasies for children, and informs the shape of the genre, its presentation in these stories is considerably complicated and compromised. And so in the Jungle Books: for all that Kipling seems to endorse this method of instruction in Mowgli's progress from animal to adult, the stories also make clear the ways that this education fails to prepare him for manhood. Exiled to the village, Mowgli finds himself painfully unsuited to life there:

First he had to wear a cloth round him, which annoyed him horribly; and then he had to learn about money, which he did not in the least understand, and about ploughing, of which he did not see the use. ("Tiger! Tiger!, " Jungle Book 95)

Just as Alice's drawing-room education renders her unfit to be a dream-child of nature, so Mowgli's natural education renders him unfit to be a Man. In the end, the hybridity that served Mowgli as a child makes him an outsider in his maturity, and, finally, at home nowhere. He is torn between Jungle and village in a way that finds no real resolution. He laments his own in-betweenness in "Mowgli's Song": "as Mang flies between the beasts and the birds," he sings, "so I fly between the village and the jungle. Why?" (Jungle Book 123). He goes on to say that the village and the jungle "fight together in me as the snakes fight in the spring" (124). If the Jungle is the place of natural childhood, and the village the place of civilised adulthood, then Mowgli's description of his alienation in both is a moving description of the desperate contradictions of adolescence: "My heart," he sings, "is heavy with the things that I do not understand" (124).

The books insist on the fleeting endlessness of Mowgli's childhood. Endlessness is conveyed mostly through Kipling's emphasis on the wealth of stories not included: "Now you must [...] only guess," he writes, "at all the wonderful life that Mowgli led among the wolves, because if it were written out it would fill ever so many books" (22). But this endlessness is, as always in this literature, paradoxically shadowed by its ending. In The Jungle Books, this 
shadow falls over Mowgli's relation to the jungle and the animals in it as he comes to maturity. Mowgli is cast out of the Jungle in a way that is explicitly tied to the end of his childhood: "thou art a man, and a man's cub no longer. The Jungle is shut to thee henceforward" ("Mowgli's Brothers," Jungle Book 40). This is not a natural leaving - it is caused by the betrayal of Shere Khan, the tiger, and those in Mowgli's Pack who follow him and exile proves to be temporary, although in the loss of innocence caused by the Pack's betrayal Mowgli has crossed a threshold he cannot return from: "I will always remember that I love thee and all in our cave; but also I will always remember that I have been cast out of the Pack" ("Tiger! Tiger!," Jungle Book 94-5).

Mowgli's return (to the Jungle, not the Pack) after this betrayal is in itself temporary. There are a mere three years between his return in "Tiger! Tiger!" and when he leaves for the final time in "The Spring Running," when he is "nearly seventeen years old" (Second Jungle Book 264). Mowgli is caught by the same spring fever which is sweeping through the rest of the jungle in this story; sexual maturity - he leaves in pursuit of marriage - is the true end of Mowgli's childhood, and of his time in the Jungle. This leaving is linked to the first (in "Mowgli's Brothers") by the sorrow inherent in it. Endings in The Jungle Books are marked by tears; tears which are explicitly tied to the process of maturation, and to Mowgli's humanness rather than his animality. The end of childhood is an end which is seen to necessitate grief and mourning. In "Mowgli's Brothers," Mowgli cries for the first time in his life:

"What is it? What is it?" he said. "I do not wish to leave the jungle, and I do not know what this is. Am I dying, Bagheera?"

"No, Little Brother. Those are only tears such as men use," said Bagheera. "Now I know thou art a man, and a man's cub no longer. The Jungle is shut to thee henceforward. Let them fall, Mowgli. They are only tears." So Mowgli sat and cried as though his heart would break; and he had never cried in all his life before.

(Jungle Book 40) 
Crying "tears such as men use" signals the end of Mowgli's life with the Jungle animals. In "The Spring Running" there are more tears, and the same reluctance to leave, but this time, there is also an acknowledgement of inevitability, of a choice that is no choice at all: "I would not go; but I am drawn by both feet. How shall I leave these nights?" (Second Jungle Book 293). Mowgli's consolation is precisely the consolation of natural inevitability: Baloo tells him that "[t]here is no shame in this hunting. When the honey is eaten, we leave the empty hive" (293); that the Jungle, and childhood, have served their purpose and must be left behind. Kaa, the great snake, tells Mowgli that "having cast the skin [...] we cannot creep into it afresh. It is the Law" (293). Again, there is the equation of maturation with the kind of death that necessitates a natural grieving. "This," we are told with finality at the end of "The Spring Running," is the last of the Mowgli stories." Mowgli's expulsion from the Jungle with the onset of maturity makes clear how closely the world of the animal is aligned with childhood, and with childhood's particular pastoral construction. Mowgli's education in Jungle Law is complete, and the inevitability (and irrevocability) of endings is the last lesson the Jungle has to teach him.

T.H. White's The Sword in the Stone (1937) is, as in Kipling, the story of a child growing from animal to human; as in Kipling, it is a story of a Rousseauian natural education. The book tells the story of a small boy called "the Wart," who grows up in the Castle of the Forest Sauvage (not quite a Jungle, but wild all the same), and his education in kingship at the hands of the magician Merlyn. The important thing about Wart, the reason the story of his education is being told at all, is that he will eventually pull a sword out of a stone and be crowned Arthur, the Once and Future King of Britain. Wart's education consists, thanks to the magician Merlyn, of a series of magical animal transformations. Merlyn turns Wart into a fish, a merlin, a snake, an owl, a badger; the lessons Wart learns from these animals help him take up his destiny. More specifically, they help him pull the sword from the stone that holds it, handing him his birthright: the luce tells him to put his back into it; the badger tells him to remember his forearms; the merlin reminds him to never let go; the snake tells him to make everything work together: 
"Fold your powers together, with the spirit of your mind, and it will come out like butter. Come along, Homo sapiens, for all we humble friends of yours are waiting to cheer."

The Wart walked up to the great sword for the third time. He put out his right hand softly and drew it out as gently as from a scabbard. (The Sword in the Stone 280-1)

These magical transformations, we are told explicitly, are only possible because Wart is a child. As C.M. Adderley notes in "The Best Thing for Being Sad" (61), in the next book in White's Arthurian sequence (The Queen of Air and Darkness), which tells of Wart's life after he has become King Arthur, the magic (along with Wart's memory of it, his connection to the boy he was) has disappeared with his childhood:

"Do you remember anything about the magic you had when you were small?"

"No. Did I have some magic? I remember that I was interested in birds and beasts. Indeed, that is why I still keep my menagerie at the Tower. But I don't remember about magic."

"People don't remember," said Merlyn. (The Once and Future King 294)

There are many examples in The Sword in the Stone, even apart from Wart's transformations, of the kinship of child and animal. The Wart is at various points likened to a dog, a salmon, and a bird; he runs about the castle like "a rabbit in its own complicated labyrinth" (50). He is often to be found in the kennels in a puppy pile, and at one point, we are told, "he happened to be licking Cavall's [his dog's] nose - not the other way about when Merlyn came and found him" (52). The Wart endures a trial in the woods, and the wood is shown to be natural to him: "He really was small and young enough to move as secretly as the warriors. Their age and weight made them lumber, in spite of all their woodcraft, and his youth and lightness made him mobile, in spite of his lack of it" (151). He experiences, over the course of his lessons, the wildness of the earth, the sea and the air.

The close association between child and animal serves to highlight certain qualities innocence, energy and vitality, but most importantly a certain kind of timelessness or 
iterative eternality - that we, as a culture, ascribe to childhood. In a story called "The Mousewife," Rumer Godden writes:

In the old nursery rhyme, when the cat went to see the queen, he caught a little mouse under her chair; that was long, long ago, and that queen was different from our queen, but the mouse was the same.

Mice have always been the same. There are no fashions in mice; they do not change. If a mouse could have a portrait painted of his great-great-grandfather, it would be the portrait of a mouse today. (9)

The importance of this iterative endlessness in children's literature, the way that it constructs a cultural childhood that is figured as both eternal and eternally fleeting, is clear. The fact that the Wart is also the Once and Future King only further underscores this iterative quality: the child is dead, long live the child.

Writing within the framework of Arthurian legend is, in itself, a form of nostalgia: The Sword in the Stone looks back to an old Merry England, an England of childhood idyll, when even the weather "behaved itself" in accordance with nostalgic adult memory:

In the spring all the little flowers came out obediently [...]; in the summer it was beautifully hot for no less than four months, and, if it did rain just enough for agricultural purposes, they managed to arrange it so that it rained while you were in bed; in the autumn the leaves flamed and rattled before the west winds, tempering their sad adieu with glory; and in winter, which was confined by statute to two months, the snow lay evenly, three feet thick, but never turned into slush. (187)

The narrator interrupts the story at various points to underline the pastness of his tale, insisting on the differences between the world he is describing and the present. Addressing the child reader directly, he writes, "The Castle of the Forest Sauvage is still standing, and you can see its lovely ruined walls with ivy on them, standing broached to the 
sun and wind" (47). White's narrator contrasts its past glory with its present ruin, emphasising the importance of the transmission of memory in making the castle "grow around you again": "On this tower the look-out moved. From here he kept guard over the blue woods towards Wales. His clean old bones lie beneath the floor of the old chapel now, so you must keep it for him" (49). This passage speaks to the function of memory and legacy in children's literature more generally, and the Arthurian subject matter throws this function into sharp relief. As a whole the narrative is very focused on the passage of time - White pays close attention to the cycle of the seasons, and most of the chapters begin with clear time stamps - but the story is one of explicit eulogy: the place being described and all the characters that populate it are "clean old bones beneath the chapel." This is a mythical past, a past in which "the forests rang with knights walloping each other on the helm, and the unicorns in the wintry moonlight stamped with their silver feet and snorted their noble breaths of blue upon the frozen air" (187), a past in which a boy could be transformed by magic into an animal.

The identification of child and animal in this story is characteristically double-edged, shaded by mortality. The child as animal carries disquieting echoes of the child as meat, highlighted in this book when Madame Mim captures Wart and Kay and puts them in her hutch for fattening: "'How the creature scratches,' said Madame Mim. 'Bless us, how he wiggles and kicks, just for being a pagan's dinner [...] the partridge with a plump breast, how he does squeak"' (76).

But even red in tooth and claw, animal society is elevated above human society in The Sword in the Stone. We can see that White depicts the people that surround the Wart as he grows up with humour, with a certain insight, and with deep fondness. However, his adults salt-of-the-earth Sir Ector ("Ought to be havin' a first-rate eddication, at their age. When I was their age I was doin' all this Latin and stuff at five o'clock every mornin'. Happiest time of my life. Pass the port"(8)), the nurse, the barrel-chested sergeant - are presented as wellmeaning, but inescapably silly. Wart's night of dignified "silver silence" and real peril among 
the birds of prey in the mews is contrasted explicitly with the schoolboy antics of the bumbling adults King Pellinore and Sir Grummore during their joust - Pellinore cheats by mumbling 'non' under his breath, and Grummore calls him a cad. The knightly vigil of Wart's foster brother Kay involves taking a bath and receiving a lecture on ideals from these two comedic figures; Wart's (for his night in the mews is nothing less than a vigil) is described with the utmost solemnity:

Each hawk or falcon stood in the silver upon one leg, the other tucked up inside the aprons of its panel, and each was the motionless statue of a knight in armour. They stood gravely in their plumed helmets, spurred and armed. The canvas or sacking screens of their perches moved heavily in a breath of wind, like banners in a chapel, and the rapt nobility of the air kept their knight's vigil in nightly patience. (111)

True nobility and honour and wisdom are found in this story within animal society, among the trees and the stones. Wart is set apart by his association with the animals around him, made more adult than the adults in his life. Compare the two models of kingship that Wart encounters in the story: King Pellinore is sympathetic and essentially good, but he is also bumbling, inept and slow, failing to be any example of leadership or resolve. During his adventure as a fish, on the other hand, Wart meets a pike named Old Jack. Merlyn calls Old Jack "the King of the Moat," and tells the Wart, "you will see what it is to be a king" (61). This, according to T.H. White, is what it is to be a king:

The great body, shadowy and almost invisible among the stems, ended in a face which had been ravaged by the passions of an absolute monarch, by cruelty, sorrow, age, pride, selfishness, loneliness and thoughts too strong for individual brains. [...] He was remorseless, disillusioned, logical, predatory, fierce, pitiless: but his great jewel of an eye was that of a stricken deer, large, fearful, sensitive and full of griefs. (61) 
And this is what it will be for the Wart to be a king. The story of King Arthur is necessarily teleological; it is informed and defined by its ending. Even in this book, which closes after Wart pulls the sword from the stone, ending his life as Wart and beginning his reign as Arthur, we are never allowed to forget that this is a tragedy starting to happen. The arrow that Wart looses into the air to salute his first prey is only one of the portents described:

as the arrow topped the trees and climbed into sunlight, it began to burn against the evening like the sun itself. [...] Just as it had spent its force, just as its ambition had been dimmed by destiny and was preparing to faint, to turn over, to pour back into the bosom of its mother earth, a terrible portent happened. A gore crow came flapping wearily before the approaching night. It came, it did not waver, it took the arrow. It flew away, heavy and hoisting, with the arrow in its beak. (65-6)

This is Arthur's story in one image - "burning ambition in the sunlight" (65), interrupted by a carrion crow. Arthur's reign will end with his defeat at Camlann, the failure of his ideals, the breaking of the Round Table, and his departure from the world. Aaron Isaac Jackson speaks of "the narrative's palimpsestic juxtaposition of the past and the present and its crucially ambivalent temporality at the point of interface between mythology and history" (52). Merlyn himself is a large factor in this ambivalent temporality, living as he does, backwards, anachronistically. This reversal in Merlyn's experience of time - the idea that as a mage he remembers the future as well as the past - is not precisely White's invention: it is a characteristic of the character both in legend and in other modern retellings such as Rosemary Sutcliff's King Arthur trilogy. But White turns it to his own peculiar ends. It is, characteristically for this story, used for humour - we first meet Merlyn at his well struggling with a bucket, muttering "I wish to goodness [...] that I was only on the electric light and company's water, drat it" (31) - but Merlyn's presence and his backward journey through time also turns to tragedy. As Merlyn has already lived through the conclusion to Arthur's reign, and already knows what will happen, the narrative is predestined to end as has always 
been told and will be told again, in defeat and death. Arthur will also, as has been told, defeat death.

This speaks directly to my larger thesis about the causes of the mortal notes, the celebration and lament that are inscribed in the writing of the child in children's literature. The child is written as embodying both memory and hope; it is a representation of a paradoxically eternal present tense that holds both an irrecoverable past, and an inexorable future within it. In this context, Arthurian legend with its echoes of once and future has a peculiar resonance. Childhood in children's books is haunted by its future end, and Arthur's childhood in The Sword and The Stone, explicitly so. There is a touching passage towards the end of the book where Merlyn's knowledge of the Wart's eventual defeat collides with Wart's innocent - and as yet unknowing - optimism:

"If I were to be made a knight," said the Wart, staring dreamily into the fire, "I should insist on doing my vigil all by myself, as Hob does with his hawks, and I should pray to God to let me encounter all the evil in the world in my own person, so that if I conquered there should be none left, while if I were defeated, it would be I who would suffer for it."

"That would be extremely presumptuous of you" said Merlyn, "and you would be conquered, and you would suffer for it."

"I shouldn’t mind."

"Wouldn't you? Wait till it happens and see." (252)

The change in tense at the end is telling. Merlyn's distress is, characteristically for White, both moving and funny:

"Well, anyway," Merlyn said. "Suppose they didn't let you stand against all the evil in the world?"

"I could ask," said the Wart.

"You could ask," repeated Merlyn.

He thrust the end of his beard into his mouth, stared tragically in the fire, and began to munch it fiercely. (253) 
Wart will not remain an embodiment of potential, sunny and unsullied by grief, and Merlyn, tragically munching, knows it, and mourns in advance. The very qualities that mark the Wart out as extraordinary - his dreams of valour, the weight of the unknown future upon him, his role in the shaping of the world to come - also underline the qualities that make him representative of childhood. Linking King Arthur's destiny to the tale of a small boy much like all small boys serves to make a larger point about cultural childhood, and more particularly about childhood in children's literature: it is always an ending beginning to happen, it is always an ending held at bay, it is always once and future.

The potent symbolism of Arthurian legend, and the way that this legend can align with the cultural freight of literary childhood is picked up half a century later in Jane Yolen's Young Merlin Trilogy (Passager (1996), Hobby (1996), and Merlin (1997)), a series of three short books about the childhood of Merlin the magician. Yolen frames Merlin's origin as an animal story, and it is told in terms of immaturity and wildness, taming and transition. These books are not classics like the other works considered here, but they serve to demonstrate how strongly the complicated origins and manifestations of the child's alignment with animals make themselves felt in animal stories more generally, and how deeply intrinsic the shadow of mortality is to that alignment. It is true that Yolen's work lacks T.H. White's idiosyncratic brilliance, but in its very straightforwardness (it is aimed at much younger readers) it is a clear example of genre, demonstrating the essential elements of both the animal and the Arthurian story for children, as well as how central endings are to both.

Both the Jungle Books and The Sword in the Stone are important sources for Yolen. Like Mowgli and Wart before him, young Merlin in these stories is aligned and identified with animals; like Mowgli and Wart, Merlin grows from animal to human in complicated and somewhat ambivalent ways. These ambivalences, as in The Sword in the Stone, are only amplified by Merlin's special status as the mage of Arthurian legend. In her author notes, Yolen acknowledges the richness and variety of the Arthurian source material that her story both uses and manipulates to her particular purposes. The story of Merlin, she tells us, "is 
not one story but many, told by different tellers over fifteen centuries" (Passager 75). Merlin is variously aged wizard, seer, shape-shifter, druid priest, wild man, or sage. Yolen's decision, then, to make Merlin a feral child - one who must come into his humanity, and then into his magic (the quality that makes him more than human) through what is essentially a process of grieving - is a telling one.

The first book in the series, Passager (the term for a falcon, not yet mature, who has been caught in the wild and trained by the falconer, summing up Merlin's character arc in the story), begins with Merlin's abandonment in the woods by his mother. He is rarely named throughout the book - he is "the boy" only, highlighting both his lack of belonging to a community, and also his essential childness, his status as a literary representation of childhood. From the first, he is linked to the birds he is named for: he is "such a little bird, my child, my owlet, my hawkling" (Passager 2), and this identification reinforces his status as akin to animal, somehow less than, or at least different than human.

Characteristically for animal stories, the boy's life in the woods is shadowed by mortal threat: like birds, he finds his only safety and refuge in trees and heights. He carries a stick at all times for self-defence, and his existence is marked by dirt, and cold, and hunger. The link between the child and nature is, as in the Jungle Books, double-edged: far from being representative of careless innocence, the natural world here is distinctive in its danger. The child is framed as prey, as for example in the boy's dream about a pack of wild dogs:

The dogs were enormous, with eyes as great as saucers, as great as dinner plates, as great as platters. They stared at him and through him, and - in his dream - his skin sloughed off. He watched, skinless, as the dogs ate his skin. Then they turned and stared at him with their big eyes and growled. (28)

Like Mowgli, Merlin is alone among the animals, but in contrast to Mowgli, Merlin remains essentially separate from them. He "spie[s] on little animals for entertainment" (6) but cannot join in their games; he imitates birdsong and the warning call of the wild boar, but the animals do not speak back to him. There is no hint of the complex and interlocking 
highly 'civilised' and hierarchical animal society that Kipling builds in his Jungle, nor is there any sign of Kipling's Jungle Law, except in its most basic form: the law of hunger and its sating. The boy in Passager is isolated in a way that Mowgli never is.

Over the year that the boy spends in the woods ("for an eight-year-old that is a good portion of a lifetime" (8)), his loss of language - and, concomitantly, his loss of memory - is almost total: "Time for him was always now [...]. His history, all of the past, made no more sense to him [...] and as more and more of his human words fell away - having no one to use them with - so did his need for past and future" (12). This speaks both to Yolen's framing of language as essentially human (this is not a book of Talking Beasts), and to the close link between animals and children that has already been outlined; it speaks to why the child is so often identified with the animal. There is an unremitting present vitality that is shared by both animal and child, at least from the distance of adulthood. This orientation in the present is heedless of both past and future - heedless of time and context - in a way that adults, with their inescapable and growing historical perspective (their ever expanding past and shrinking future), can never manage to be. Paradoxically, this lack of context in time only serves to emphasise time's inevitable working: the endless present tense of the animalchild has an inevitable ending, and this ending casts a shadow.

By the time that he comes upon the falconer - Master Robin - taming a falcon in the woods, the boy is ready for this ending. Shortly before his meeting with the man, the boy watches geese migrating - passaging - and feels a longing that marks the beginning of his separation from his context-less animal existence: "he watched them for a long time, yearning for something. He did not know what" (13). This yearning is an acknowledgement of loneliness and lack, a sign of the need for human community. Again, the world of the human is linked with language and the ability to communicate: "He waited for a reply [from the geese] but none came. Unaccountably his right eye burned. He rubbed his fist in it and the fist was wet" (14). Crying is intimately attached to humanity in this story (as it is for Mowgli in the Jungle Books): we are told that the boy "did not cry. An animal does not cry" 
(7). His burning eye and wet fist signal the beginning of his slow reconnection to people. There is no doubt, once he stumbles over the man and his bird, that the boy will follow them both out of the woods and into the house, as effectively lured and hooded as the bird the man has spent the night so patiently taming.

This explicit framing of childhood as a form of wildness, of the process of maturation as a kind of taming (the boy is "fierce indeed. And needing taming, I suspect" (34)), is familiar from the Jungle Books. Here, it highlights just how strangely equivocal the traditional link between the child and the animal is, especially given how closely childhood is also tied to the domestic: the boy is both entirely natural and entirely unnatural unchildlike - in his wildness. Taken into the house, the boy has no idea how to live there. He urinates around his bed to mark his territory; he eats bread and butter, but then licks the tray and the floor around it, making it suddenly, shockingly, clear that he has been eating on all fours, like a dog out of a bowl. "By the fifth day, the room smelled and the floors bore the filthy reminders of the boy's wood habits" (46). This kind of detail is usually elided from the close association that is drawn between child and animal in children's literature, and it demonstrates just how uneasily the child of nature sits in the domestic setting that is also traditionally linked to childhood. It demonstrates further just how dissonant the adult stance toward childhood is. The boy remembers in a dream a lullaby once sung to him: "Lullay, lullay, thou tiny child / Be sheltered from the wet and wild," and remarks on this dissonance himself: "But, he thought, I am wet, and I am wild" (36). After the boy has wept, a sign of human, rather than animal emotion, his wildness is contained (much more comfortably for the reader) in play: having found a pile of fur robes in the wardrobe of his room (there are echoes here of Narnia, and the fur coats in the wardrobe between worlds - here the boundary lies between the world of the child/animal and the world of the adult/human) he wraps one over his shoulders, and "going down on all fours, he threw back his head and howled" (50). 
The boy's civilising in Passager is framed as an act of memory. He does not learn words (and through words, language), he remembers them, regains them. He repeats the words he remembers, naming "all the things that had been given back to him, starting with the bread" (40). Memory is explicitly tied to language, and to names in particular, in a way that recalls Alice, leaving behind the green world and recalling herself. Yolen writes that "memory as well as language came flooding through [the boy] as he was given back his own true name" (70). It is a peculiarly apt metaphor for growth. Leaving childhood behind is linked with the constantly growing past that comes with added years, and maturity framed as a growing store of memory.

But here, as in The Jungle Books and The Sword in the Stone, growing from animal to human is not simply an accumulation of memory, but also, inevitably, an experience of loss and bereavement. There is an insistence, in this book and its two sequels, on the pain of endings. The boy comes to live in Master Robin's house unable to cry; instead, he howls, like the dogs he runs from in the woods. The turning point in his transition from outside to inside is the point at which the boy, realising the wood and his old life is lost to him, lets loose a howl that transforms midway from animal to human grief:

... he threw back his head to howl once again, but this time the howl died away into a series of short gasps and moans. He went back to the bed and curled into the covers and wept, something he had not done in a year. (44)

The second and third books in the series, Hobby and Merlin respectively, both detail Merlin's life after he leaves the woods and re-joins humanity, but the woods are not entirely left behind. Neither is the close association between animal and child that forms the crux of Merlin's characterisation, nor the insistence on grief and loss as rite of passage (an inevitable stage and consequence of maturation) that is so important in his story, as it is told here. The second book, Hobby, set four years after the first, begins with traumatic loss, with the destruction by fire of the home that Merlin (or as he is called in this book, "Hawk" and "Hobby") had found with Master Robin, and the family he had found within it. "The boy 
buried them all in a single grave: dog, woman, and the charred remains of the others" (Hobby 3). He finds a new family in the travelling act of the magician Ambrosius and the Lady Viviane - a reference perhaps to the Lady in the Lake, responsible for Merlin's imprisonment in legend - but the book ends with another loss when they abandon him: "So they have flown the dovecote, leaving the little pigeon behind" (78). Alone again, Hawk returns - indeed, flees - back into the woods.

In between these two separate griefs, Hawk learns the tricksy, sotto voce habits of human civilisation ("Ambrosius and Viviane's lessons were [...] twisty somehow. And full of lies" (53)); he also learns that threat and predation are not left behind with the pack of wild dogs that pursued him in Passager. In Hobby, the threat is an evil man, calling himself Fowler, who meets Hawk on the road, and claims him as a kind of property: "No one will wonder about us, Hawk realised. No one will question the man's right to sell us all: horse, cow, boy. Even dog" (22). Again, the boy is akin to animal, but this time he is a form of livestock, an economic asset rather than a wild thing. The close association of child and animal continues in this book, even as the wildness of the feral child is past: Hawk is "a small hawk among pigeons" (55); at one point he eats so much he feels ill and curls "like a dog, three times around before settling on a cushion near the hearth" (60). The complicated link drawn in Passager between animal and childhood passion and grief, is revisited in Hobby in the connection between crying and howling: "he did not make a sound as he cried. He was afraid if he started, his howling would never stop" (Hobby 6).

The third and final book in the trilogy, Merlin, forms a kind of synthesis between the feral isolation of the first book, and the civilised, yet threatening society of the second. Merlin comes upon a community of "wodewose," people who have retreated to the forest and live on the margins of human society. Merlin finds no home with the wodewose: they learn of his ability to dream the future and hang him in a cage, "like a criminal hung up at the crossroads to starve. Or like [...] a beast in a trap" (Merlin 46-7). While there is still a strong insistence on Merlin's origin as painful and lonely, as marked by loss ("Everything, he 
thought wildly, everything conspires to keep me on my lone" (4)), this book begins to emphasise the shadow of Merlin's future.

Even as Merlin is a "small hawk among the pigeons," it is acknowledged that he "will be a hawk among princes" (Hobby, 69). This is a child with a very particular destiny as King Arthur's mage, and (as with Wart before him) the very singularity of the child hero - his status as a figure of both legend and myth - serves only to underscore the things about him that are ordinary and universal: "he mumbled his own name and, with that, fell asleep once again to dream - as boys often do - of dragons" (10). Merlin's dream of dragons specifically, his dream of the white dragon, and the red, whose battle in an underground cavern brings down the tower above them, prophesying the death of Lord Vertigern and the beginning of Arthur's ascent- marks his entrance into Arthurian legend. It is also, as Yolen writes, a dream that boys have. Asked what he is in reference to his magic ("He is Dreamer [...]. He is breath of Dream. He is Maker" (63)), Merlin answers in terms of childhood and the loss that seems to be its constant companion: "I am a boy [...]. I am...an orphan [...]. I am alone" (64).

In Merlin, we finally meet King Arthur (far before his kingship - here, he is the "Cub" of the wodewose village). Like Merlin, Arthur is intimately linked to animals ("'I can be a fox,' Cub said, 'I can be a wolf"' (77)), and finds his origin in pain and death. The village he has grown up in is slaughtered; his drive to rule is tied to that loss, to his desire for a power that will overcome it. Like Merlin, Arthur's power is tied to his animal name, Artos, meaning 'bear': the Cub says that he will be "as big as a bear. Then no one would kill what is [his]" (85). Of course, Arthur's wish is futile: while Merlin himself breathes life, resonantly, back into a dead bird, he cannot bring the people of Arthur's village back to life after that village's destruction, nor can he avert his own inevitable death. The book ends with Merlin's passing (still the passager) set at some indefinite time in the future, and with Arthur's grief. Yolen, like all authors of children's fantasy, focuses on the inevitability of endings: "If I am 
powerful, then no one can hurt me. Or mine," Arthur tells us. "So why do I hurt so now that he is gone?" (88).

There is a discussion in the prologue to Merlin of the interconnectedness of childhood, dream, memory, and loss. It is a conversation between Merlin and the child Arthur, again set at an indeterminate time in the future. Told that there is more to becoming an adult than games, Arthur expresses a Peter-Pan-like wish to never grow up: "I do not wish to become an adult. I wish to remain a child and play games" (2). Upon hearing that even Merlin, with his great powers, cannot stop the wheel of "dark to light to dark again" that measures a lifetime, Arthur asks:

"Then what will be left of childhood when we are grown old and gone?"

"Dreams are left [...]."

"I do not want to be someone else's dream [...]. I mean to stay awake." (2)

This, with its echoes of Alice, the dream-child of Lewis Carroll, herself dreaming of Wonderland, speaks explicitly to children's fantasy as a genre: to childhood as a dream or an imagining that combines both past and future; to the child figure that is constructed, essentially, as "someone else's dream," a dream containing, as many childhood dreams do "blood and fire, fire and blood" (Hobby 19). Arthur's desire ("I mean to stay awake") is both universal and impossible, and all of these stories cannot help but acknowledge both the wish and its futility.

Charlotte's Web by E.B. White (1952) locates its action not in the savage Jungle, nor in the Wild Wood, but (for the most part) in a barn on a domestic Mid-Western farm in what Roger Sale calls "standard American idyllic" (245). The book begins with a child, Fern Arable, Bunyanesque of name and sensitive of heart, who is aligned and allied with the animals around her, particularly with the piglet runt whose life she saves in the first pages of the novel. Fern's identification with Wilbur the piglet ("if $I$ had been very small at birth," she asks her father, as he heads out with an axe to rid himself of the economic burden that the 
runt represents, "would you have killed me?" (8)) is unquestioned. Roger Sale, in his history of children's fantasy, contends that:

childhood came to be thought of [...] as a special time, as the one period of life in which it was acceptable to believe in the magical, the imagined world, the speaking animal. The child was imagined to be able to enjoy an instinctive sympathy with and understanding of animals and an alliance with animals against adult human beings. (81)

The first pages of Charlotte's Web play this trope out straightforwardly: Fern sides with Wilbur against the wishes of her father, and when Fern's mother worries about Fern associating too closely with the animals, "pretending that they talked," Mr Arable replies that "maybe our ears aren't as sharp as Fern's" (Charlotte's Web 57). But Charlotte's Web is not the story of Fern and her piglet, her companion and other self, at least beyond the first two chapters. The intense bond between girl and pig lasts only for the first five weeks of Wilbur's life. After Wilbur moves to the Zuckerman barn in chapter three, Fern becomes a silent presence in the story, and eventually fails to be present at all. In chapter three, White works what Sale calls "his one magical trick" (259) ${ }^{18}$, and slides gradually and subtly from realism to Talking Beast fantasy in which the animal, instead of being merely aligned with the child, replaces her as protagonist. For our purposes, the shift from association with animals to identification with them has one major effect: it underscores the teleological nature of the animal story. Wilbur (and the childhood with which he is so closely associated) is a symbol of vital energy. He is greedy, intense, and intensely physical: his existence in the barn is shown to be both blissful and terrifying, and his life is made significant by the spectre of its ending.

White's story conceives of life (and childhood as life's microcosm) as precious because it is fleeting, and this fleetingness is conveyed by the overall structure of the book,

\footnotetext{
${ }_{18}$ Perry Nodelman discusses this "one magical trick" in detail in "Text as Teacher: The Beginning of Charlotte's Web": "after reading the first two chapters, someone with no prior knowledge [...] could only be surprised that the book deals with the friendship of a pig and a spider who talk to each other. There is no spider at all in those two chapters, and the pig in them doesn't talk" (115).
} 
which covers only a year, chronicling the seasons and their changes in meticulous detail. At the beginning of summer, "[t]he song sparrow, who knows how brief and lovely life is, says 'Sweet, sweet, sweet interlude; sweet, sweet, sweet interlude'" (Charlotte's Web 46). The crickets, in their turn, a short fifty pages later, sing in the end of summer: "a sad, monotonous song. 'Summer is over and gone,' they sang. 'Over and gone, over and gone. Summer is dying, dying"' (110). And the book's sense of life as "brief and lovely" is only emphasised by having animal rather than human protagonists. Wilbur is relatively shortlived, and able to reach maturity over the year that the book spends with him (even as he remains a pig in a way that Fern cannot remain a girl). Charlotte, the industrious spider who works to ensure that Wilbur will enjoy a full and happy lifetime rather than being slaughtered for meat, has an even shorter span, and indeed, dies before the end of the story.

It is common for critics to repeat White's own description of Charlotte's Web as "a paean of life, a hymn to the barn" with approval. ${ }^{19}$ In a letter to his editor shortly before publication, White talks about the impulse that caused him to write Charlotte's Web. He writes that he wanted the novel to counter what he felt to be the inherent emotional hypocrisy in the practice of rearing and caring for livestock in order to slaughter them:

It used to be clear to me, slopping a pig, that as far as the pig was concerned I could not be counted on, and this, as I say, troubled me. Anyway, the theme of "Charlotte's Web" is that a pig shall be saved, and I have an idea that somewhere deep inside me there was a wish to that effect. ("A Book is a Sneeze")

The wish is granted: Wilbur survives the threat of the axe, and thrives. But Charlotte, his best friend and mentor, dies. In White's "paean of life," the fact that both plot and theme culminate in the death of a small grey spider (whom successive generations of readers have stormily mourned) becomes even more striking. It speaks to how central mortality is to

${ }^{19}$ These include Roger Sale, Fairy Tales and After, page 258 and Perry Nodelman, "Text as Teacher," page 116. 
White's conception of vitality, and to how foundational the sense of an ending is in the animal stories of childhood.

Charlotte's death is foreshadowed heavily: the narrator steps in when Wilbur first encounters her to reassure the reader that despite her fearsome and bloodthirsty appearance, Charlotte "was to prove loyal and true to the very end" (44). From the first meeting, then, there is the spectre of a "very end," and it is telling that this spectre is raised as reassurance. There are many signs, as the end of the year approaches, that Charlotte will not be staying long. We are told that she is tired, and slower, and older; she tells Wilbur, "I feel like the end of a long day" (131). More precisely Charlotte is the end of a long year: Wilbur is a spring pig, summer is a time of fullness, and Charlotte declines in the autumn (the American term "fall" would here be most apt). Her death, when it comes, is portrayed as the end of a long and natural process. Charlotte's life's work is saving young Wilbur from an untimely death; with her own death, she demonstrates the consolations of timeliness.

Of course, this being an animal story, timely death is hardly a given. The setting in Charlotte's Web is a farm rather than the savage Jungle or the wild Forest, but animal life on a farm is still ruled by appetite. Wilbur is told outright in the chapter called "Bad News" that "they're fattening you up because they're going to kill you [...]. Turn you into smoked bacon and ham" (52). Wilbur's terror and dread is explicit: "I don't want to die [...]. I want to breathe the beautiful air and lie in the beautiful sun" (53). Here we see another effect of replacing the child protagonist with an animal: Fern in the first chapter can defend Wilbur by drawing a likeness between them to sway her father, but the fact remains that Fern is not food. Fern's ending, like Mowgli and Wart and Merlin, is to grow up and away from the animal world and into human society. The shadow hanging over Wilbur is more explicitly mortal, and fantasy (Wilbur's status as a Talking Beast) allows him to voice his own terror.

For Wilbur and the other animals in the barn, domestic security and comfort is complicated and circumscribed by their knowledge that they are kept for what they can 
provide to those who feed and keep them: labour, milk, eggs, wool, and their own flesh. E.B. White addresses this issue explicitly in the letter quoted above:

A farm is a peculiar problem for a man who likes animals, because the fate of most livestock is that they are murdered by their benefactors. The creatures may live serenely but they end violently, and the odor of doom hangs about them always. ("A Book is a Sneeze")

The "odor of doom" descends on Wilbur from the very first line of the book, on the day of his birth, when Fern asks "Where's Papa going with that axe?" (7). Even after Fern saves him and he reaches the Arables' kitchen with its air of "coffee, bacon, damp plaster, and woodsmoke from the stove" (8) - surely one of the kitchens that "occur" according to Humphrey Carpenter, "again and again as Good Places, scenes of womb-like serenity and domestic contentment" ("Excessively Impertinent Bunnies" 286) - the odor of doom hangs about Wilbur, literally, in the homely smell of bacon. Furthering the book's complication of domestic space, and the way that the story brings death into the home instead of shutting it out in the wild, the farm is mirrored in miniature by Charlotte's own home, the web of the title. As well as being the instrument of Wilbur's salvation, described in loving detail and intricately beautiful, the web is also the killing field in which Charlotte traps her food.

There is much made, too, of the fact that the animals in the barn, for all of their material comfort, are trapped there. In chapter three, entitled "Escape," Wilbur, bored and listless in his comfortable barn, pushes through a loose board in the fence and is both elated and unnerved by his short-lived freedom. The reaction of the farm creatures ("Every animal stirred its head and became excited to know that one of its friends had got free and was no longer penned up or tied fast" (23-4)) directly mirrors (in another example of close association) the élan of the human children set temporarily loose in the fairgrounds at the end of the story, who "danced off [...] towards the wonderful music and the wonderful adventure and the wonderful excitement, into the wonderful midway where there would be 
no parents to guard them and guide them, and where they could be happy and free and do as they pleased" (127).

This impulse to freedom, balanced against a need for guardianship and guidance, and the depiction of a domestic security that carries within it both constraint and threat, is everywhere in the work of Beatrix Potter, whose little books worked to both define and shape the modern children's animal story. It is in the work of Beatrix Potter that we find the direct antecedents of E.B. White's close observation of animal life; of White's focalisation through very ordinary animal characters who matter only, in the general scheme of things, to themselves and to each other; of White's celebration of the ordinary and the unsung; of his insistence on the shadow of the axe. All of these elements can be found in The Tale of Peter Rabbit (1902), the first and most iconic of Potter's little books, which is characteristic of her body of work in its understated but undeniable sympathy for the energetic transgressor at its centre. What is tragic and elegiac in the work of E.B. White, however, becomes comic in Potter's tale.

The story is well-known: unlike the well-behaved and obedient Flopsy, Mopsy and Cotton-tail, little Peter (it is worth contrasting his human name with the pet names of his sisters) squeezes under the gate of Mr McGregor's garden, and gorges himself on the vegetables he finds there: "First he ate some lettuces and some French beans; and then he ate some radishes; and then, feeling rather sick, he went to look for some parsley" (Potter 910). After running into Mr McGregor round the edge of a cucumber frame ("Stop, thief!" (10)), Peter is forced to run for his life. Even after Mr McGregor stops chasing him ("he was tired of running after Peter. He went back to his work" (13)), Peter is trapped in enemy territory, with "not the least idea which way to go" (14). After being stymied by a locked door and a white cat, he slips under the gate to the safety of the wood outside the garden, and runs straight home.

Carpenter points out, persuasively, that Peter is not in the end punished for disobeying his mother's direct order to stay out of Mr McGregor's garden - indeed, his 
mother never learns of his offence. She merely wonders what he has done with his jacket and pair of shoes. He is put to bed and given camomile tea, not for being naughty, but because he has caught a cold from hiding in a watering can full of water. Having gorged himself to the point of needing parsley earlier in the day, it is questionable whether he could have managed the bread and milk and blackberries that his sisters get for supper. Humphrey Carpenter notes, in his study of Beatrix Potter's stories as subversive of "the 'well-established tradition' of English children's stories about animals and exhorting the reader to good and docile behaviour," that "the leg of the moral tale is being gently but quite definitely pulled" ("Excessively Impertinent Bunnies" 286-7).

Potter was a keen and accurate naturalist. Alison Lurie notes the "charm, delicacy, and accuracy of observation" in the illustrations that accompany her tales (Don't Tell the Grown-Ups 91), and Peter Hollindale suggests that "natural history [...] governs both moralism and sedition" in Potter's work ("Aesop in the Shadows" 99). Here, as in all Potter's stories, there is an element of quietly subversive joy taken in non-compliance with 'civilised' rules of behaviour: non-compliance is characterised in her work as natural, as emblematic of animal vitality, and Potter's stories are a celebration of the vital.

Elizabeth Hale, in her discussion of the beastly children and childish beasts of Saki, Beatrix Potter, and Kenneth Grahame, makes clear how far Romantic natural innocence and animalistic amorality meet in the figure of the pre-socialised child, and erases the divide between the natural and the ruthless:

These characters are driven by a fierce internal logic that cuts across social convention and the needs or desires of other characters: particularly when they write about children, Potter, Grahame, and Saki characterize bad behaviour as wild, natural, even honest. They do this by associating wildness with animal behaviour; in doing so, they draw on Romantic ideals of the child's purity and honesty (in the face of corrupt adult society), as well as on ideals of animality. [...] However troublesome to adults this behaviour might be, it underscores the natural 
and original qualities of idealized childhood, in stark opposition to the corruption and mixed motives of the adult world. ("Truth and Claw" 191)

The "fierce purity" (196) and directness of purpose that Hale describes in Potter's naughty characters is a direct expression of the tangled relation of the innocent to the bestial in the pastoral of childhood: these seemingly dissonant characteristics are manifestations of precisely the same prelapsarian state. Natural does not mean nice, and Hale points out that "the emphasis on the child as part of nature, as ruthlessly truthful regardless of whether he is good or bad, on the importance of desires, drives and instincts, as opposed to the compromised nature of socialised adult existence, is what distinguishes the Edwardian vision of childhood" (204-5), both from the traditional rhetoric of Romantic innocence, and from Victorian ambivalence about the cruelty of the natural world. This is childhood, in Barrie's peculiarly Edwardian phrase, as "gay and innocent and heartless" (Peter and Wendy 178).

Potter manages this doubled presentation through her interest in natural history and skill as a natural historian, which manifest, as Hollindale argues, in two equally important ways:

On the one hand, there is the fondness for real, individualized animals, for animals as a kind of people - the childhood pets, and those of adult life, with names and characters immortalized [...]. And simultaneous with that, the scientific, detached observation, the dissections, the forensic skill, the ruthlessly practical farming. There is here a consistent double perspective which can make the brown rat, Samuel Whiskers, both a person and a pest. ("Aesop" 94-5)

So it is for Peter, garden pest of Mr McGregor, and coddled son of Old Mrs Rabbit. Peter must shed his shoes and coat in order to save himself, but this shedding also, tellingly, costs him his visual distinctiveness: bounding away from the gooseberry net in the next illustration, he is less "Peter," treasured son, and more "Rabbit," garden pest, identifiable only by his position alongside the text. Our sympathies, and the sympathies of the narrator, remain with him, largely due to the mechanics of the perspective in the illustrations: "Beatrix 
Potter portrayed the world from a mouse's- or rabbit's- or small child's eye view. The vantage point in her exquisite watercolours varies from a few inches to a few feet from the ground, like that of a toddler" (Lurie 94). We see the world through Peter's eyes, and therefore, identify with him. This perspective also speaks to Potter's particular construction of childhood (one that would be revisited in E.B. White's portrayal of Wilbur): littleness and vulnerability, curiosity and an urge to disobedience, hunger, and the fear that comes from being small in a frightening and predatory world.

The double perspective that Hollindale mentions is at the heart of Potter's animal stories. For all of her sympathy with Peter's pluck, his vital energy is thrown into sharp relief by the threat of extinction that is also depicted, as will by now be familiar, as entirely natural. The narration of his adventure, and the mortal fear inside it, is characterised by an ironic, unsentimental, and dispassionate irony that belies the identification with Peter that is made clear in the perspective of the illustrations. The danger that Peter faces from his trespassing is made clear in the third sentence of the story: "don't go into Mr McGregor's garden: your father had an accident there; he was put in a pie by Mrs McGregor" (7). "Accident" is a carefully understated term for what can only be, from Mrs Rabbit's perspective, a case of capture and murder. On being pursued, Peter is "out of breath and trembling with fright" (14); tangled in the gooseberry net (caught there by the large buttons on his jacket), "Peter gave himself up for lost and shed big tears" (11); but Potter pauses the narration at this point, to note that "it was a blue jacket with brass buttons, quite new" (11).

The portrayal of nature in Potter's books leaves out none of the danger and terror of being a very small animal in a world of predator and prey. Her stories, M. Daphne Kutzer notes, are "of greed and near-death"; that they are illustrated by "quiet pastels" is in itself ironic (204). Mortal peril is always near the surface in Potter's universe, and this is reflected in the text. In The Tale of Ginger and Pickles (1909), for example, there is a death joke worthy of Lewis Carroll: 
"It would never do to eat our own customers; they would leave us and go to Tabitha Twitchit's."

"On the contrary, they would go nowhere," replied Ginger gloomily. (114-5)

It is no accident that Peter is caught, and almost undone, by his human apparel (the blue jacket with brass buttons, quite new). Clothing in Potter's stories is part of the way that she constructs childhood: the child animals are often depicted without human clothing, or with one or two simple pieces, rather than the full and somewhat fussy Edwardian costumes of many of the adult animals. Contrast Peter's blue coat with the dress, apron, cloak, bonnet and umbrella of Old Mrs Rabbit. Even in the context of an almost exclusively animal society, child characters are portrayed as more 'animal' than adult characters. This characterisation is only intensified by the propensity of Potter's child animals to burst out of their constraining and uncomfortable 'civilising' clothing, allowing them a more natural freedom. Peter, once he has lost his shoes, "ran on four legs and went faster" (11); Tom Kitten, in The Tale of Tom Kitten, can't be a kitten in his too-tight suit: he is "quite unable to jump when walking upon his hind legs in trousers. He came up the rockery by degrees, breaking the ferns, and shedding buttons left and right" (83). Potter here is demonstrating an idea that has been evident in all of the animal stories considered so far: that civilisation is assumed and applied with maturation.

Potter's distinctive use of clothing makes a larger ironic point: her unstintingly animal animals dress in human clothing and live in communities in which random and casual predation (the rule of instinct and appetite) exists alongside domestic Edwardian manners. Her animals eat voraciously, and often carnivorously, but they eat at table, with cutlery: "There were tin spoons and lead knives and forks, and two dolly chairs-all so convenient!" (Two Bad Mice 264). Culture, in Potter's work, is always merely dressed-up nature, and it is never very far from shedding its buttons.

Potential eruptions of brutality are clear, too, in Potter's depiction of domestic space, which constrains her child characters without ever quite making them safe. Domestic 
sanctity in her stories, is not so much violated as continually proven never to have existed: homes and houses are not free from the strangely mannered bloodthirstiness that characterises her universe. The rambunctious vitality of Hunca Munca and Tom Thumb destroy the careful order of the doll house in Two Bad Mice; the home of Tabitha Twitchett and her kittens in Samuel Whiskers also contains a family of rats who live in the walls. These rats pose as much of a mortal threat to Tabitha's babies as Tabitha does to theirs. In Potter's pre-industrial, nostalgically rural, ironically pastel countryside, death casts a shadow. The Tale of Mr Tod (1912) gives that shadow a particular face and a very apt name: "tod" is the word for 'fox' in northern English dialects (and Mr Tod is indeed a fox), but it is also the German word for death. And that fox figure haunts the woods: "the rabbits could not bear him; they could smell him half a mile off. He was of a wandering habit and he had foxy whiskers, they never knew where he would be next" (47). And that's the crucial point: Potter's small animals never do know where Tod will be next. All of Beatrix Potter's little books hinge, as all animal stories do, on those qualities that tie animals to literary childhood: appetite, instinct, a tension between security and freedom, savagery and civilisation, and above all, a vital and intense energy that is only intensified by the shadow that stretches across it. 


\section{Chapter Three}

\section{Memory and Legacy: Toy Stories}

Toy stories and animal stories make an intuitive pairing in children's literature. Toys appear in the animal world of Beatrix Potter, for example, and animals appear in the toy world of Russell Hoban's The Mouse and His Child; the Velveteen Rabbit sheds his velveteen and becomes simply rabbit: the appearance of one in a fantasy of the other is no surprise. Like animal characters, toys in children's books are intimately linked to literary childhood: toys, like animals, are less than or at least different than human, and they live in distinct and somewhat secret societies on the fringes of the adult world. The world of the closed toy box, or of the nursery at night with the lights off, is very like the secret life of the Jungle, the Wild Wood, the Barn, or indeed the Space Behind the Wainscot. Toys are depicted in children's stories as diminutive, and, like children, they live, in Neil Gaiman's phrase, "at the mercy of giants" (Mr Punch n.p.). Like animal characters, toys in children's books are figured as both natural companions to, and natural representations of, the childhood with which they are so closely identified.

Jerry Griswold, in Feeling Like A Kid, groups "talking animals [...], living toys [...], and animations of nature (the Man in the Moon and My Shadow)" together as examples of the "Aliveness" that he claims is one of the major distinguishing characteristics of children's stories: "For the young," he writes, "the whole universe is alive and full of companions" (2-3). David Rudd makes the same observation in "Animal and Object Stories":

the word "animal" has its etymological roots in "breath" and "soul," which link it to that which is "animate," and this is exactly the transformation that writers and illustrators so readily perform, making animals live in all manner of anthropomorphic ways. And not only animals, for other "things" are just as easily 
animated: from puppets and dolls [...] to more everyday objects such as coins, pegtops and looking glasses. (242)

This animating impulse, and the elision it demonstrates between the toy and the animal character - they are treated similarly in literary terms - are more than evident in Margery Williams's The Velveteen Rabbit: Or How Toys Become Real (1922), the story of a plush bunny who is loved and then abandoned into realness. It is a story set half-way between reality and fairy-tale, in which the days and ways of childhood are shot through with what Williams calls a special kind of "nursery magic" (The Velveteen Rabbit 14) that grants the toys in the story their own peculiar life.

Brian Sutton-Smith, in his social study of the cultural force wielded by toys, remarks that "whatever toys may have stood for in history and whatever they may tell us about human nature, they are, first and foremost, Christmas gifts" (Toys as Culture 15). He goes on to expound upon the toy as gift as part of the relation between adult and child, and on the contradictory demands it represents: "'I give you this toy because I love you and I want you to be closer to me,' says the parent in effect. 'But now go and play with it by yourself"' (53). For our purposes, it is enough to say that The Velveteen Rabbit is representative of the toy stories being considered here in the relative isolation of the childhood world of toys, and in the ways that the bond between child and toy tends to replace human connection in the narratives. There are no parents in the story at all, except perhaps in the absent hands that arranged a child's Christmas stocking, with the rabbit "wedged in the top [...] with a sprig of holly between his paws" (Velveteen Rabbit 10).

The world of the toys in The Velveteen Rabbit manages to be both intimately connected with the life of the house, and almost completely separate from the lives of the humans that reside there. The Rabbit, (first and foremost) a Christmas gift, is forgotten, and lives "for a long time [...] in the toy cupboard or on the nursery floor" (11). He is obviously being moved about, but the hands that move him are unseen and unremarked upon: the time he spends in the nursery is characterised as being empty of people. Nana, the brusque nurse 
of the household, is described as descending on the nursery every so often like "a great wind," hustling the toys into cupboards "for no reason whatever" in the name of "tidying up" (16), and the Boy, for whom all the toys are there, is conspicuous in his absence. Even after the Rabbit becomes the Boy's best beloved possession, the games they play are solitary: they have "splendid games together, in whispers" in the glow of the night-light burning on the mantelpiece, and their outings involve the Rabbit being placed in a little nest somewhere among the bracken before the Boy "wandered off to pick flowers, or play at brigands among the trees" (22).

Instead, the nursery is a place where the toys form their own parallel society, where the "long moonlight hours [...] when all the house is silent" (18) are spent in conversation among themselves. Far from being innocent of things like status and wealth, the toys are shown to have their own social groupings and pecking order, based primarily on how expensive each toy is, and how well it mirrors reality. The Rabbit is near the bottom of this hierarchy, being only plush and stuffed with sawdust: he is aware that sawdust "was quite out-of-date and should never be mentioned in modern circles" (11). But it is also in these long midnight conversations that the little Rabbit is mentored by the Skin Horse, who is "old and wise and experienced" (14), and learns of the nursery magic by which toys become "Real." Reality, in The Velveteen Rabbit, is a function of sentiment and investment by children; toys are, according to the Skin Horse, loved into becoming.

The magical process that the Skin Horse describes is essentially a spiritual transformation rather than a physical one: Reality is not "having things that buzz inside you and a stick out handle" (14); it is an effect of being "REALLY" loved for a long, long time by a child. Clockwork and physical animation are simply characteristics of another kind of toy: Williams defines Reality as a thing of the soul, a manifestation of the desire of both child and toy. The only physical transformation involved in this particular kind of metamorphosis is the one by which the Rabbit is loved into tatters: his tail comes unsewn, he becomes more and more shabby, and "he even began to lose his shape, and he scarcely looked like a rabbit 
anymore, except to the Boy" (26). The Boy (capitalised like God), is the god who confers Realness upon him: "The nursery magic had happened to him, and he was a toy no longer. He was Real. The Boy himself had said it" (19).

The second kind of metamorphosis in the story is also a product of desire, but it is magical rather than simply emotional. Crucially, the emotion that drives the magic is grief. After the Boy contracts smallpox, all the toys and books that have kept him company in his illness are deemed contagious, and put into a sack to be burned. The plush bunny spends a long, dark night of the soul out at "the end of the garden behind the fowl house"(29), and his thoughts are dominated by mournful remembrance:

Nearby he could see the thicket of raspberry canes, growing tall and close like a tropical jungle, in whose shadow he had played with the Boy on bygone mornings. He thought of those long sunlit hours in the garden-how happy they were-and a great sadness came over him. He seemed to see them all pass before him, each more beautiful than the other, the fairy huts in the flower-bed, the quiet evenings in the wood when he lay in the bracken and the little ants ran over his paws; the wonderful day when he first knew that he was Real. [...] Of what use was it to be loved and lose one's beauty and become Real if it all ended like this? And a tear, a real tear, trickled down his little shabby velvet nose and fell to the ground. (30-2)

It is this tear that summons the nursery magic fairy, and this tear that prompts her to make the Rabbit real - this time real without the capital R. He stops being a toy, and becomes a flesh and blood rabbit, joining the other wild rabbits in the bracken. His is an earthly Paradise - at the end of the book, he is able to "come back and look at the child who had first helped him to be Real" (35), and to be almost recognised by him - but there is ambiguity in the Fairy telling the wild rabbits to look after the (ex) Velveteen Rabbit, "for he is going to live with you for ever and ever!"(34). A living, breathing, mortal body does not allow "for ever and ever," and so there is the shadow of an ending over the rabbit's happily ever after, for all that he escapes death by bonfire. 
But the passage quoted above also highlights the ways in which toy narratives and animal narratives diverge. For all that the Velveteen Rabbit is vaguely bunny shaped as a toy and becomes a real rabbit with real hind legs to replace "[t]he back of him [...] made all in one piece, like a pincushion" (24), it is the Boy in the story (unnamed and every-boy) who is animal-like in his brushing away of the past and its emotional burdens, in his affection that is marked by an encompassing and short-lived intensity. The toy, in contrast, represents constancy. The eventual and inevitable leaving-behind of the Rabbit is presaged at the very beginning of the story: he is pulled out of his stocking and loved "[f]or at least two hours" (10) before being forgotten among the wrapping paper and excitement. He becomes the Boy's favourite toy on a whim, chosen at random by Nana the nurse to replace the china dog that usually kept the Boy company at bedtime simply because "it was too much trouble to hunt for china dogs at bedtime" (16). We never hear of the china dog again. The Rabbit's final abandonment is just as capricious: "For tomorrow [the Boy] was going to the seaside, and that in itself was such a wonderful thing that he could think of nothing else" (30). This is not a carelessness born of cruelty or a lack of feeling - indeed, the Boy is shown to love hard, and faithfully, over the time that he does love. Instead, it is a love that burns hot and quickly, and the Boy's carelessness is the result of his very orientation in the present moment. He loves with abandon, and then abandons his love. This is reminiscent of the eternal presentness of Peter Pan, who forgets even Tinkerbell in the end, and Barrie's characterisation of childhood as "gay and innocent and heartless" (Peter and Wendy 232).

It is the Velveteen Rabbit, instead, who remembers the past with longing, and who mourns the "bygone mornings" (30). It is the Rabbit who is ever-conscious of time and its passage, who remembers a lifetime in the short year that the story covers: The Velveteen Rabbit is reminiscent of Charlotte's Web in this way, beginning at Christmas, cycling through the "Spring Time" and "Summer Days" of the Rabbit's life with the Boy, who falls ill in autumn and then abandons him. The Boy and the Rabbit encounter each other for the last time in the woods the following spring. This is a year in which an entire childhood is contained - it is childhood condensed and concentrated (like the book itself, over very few 
pages), creating the effect of a youth that seems both to last forever, and to pass in the blink of an eye. And it is not the intense and consuming love between the Rabbit and the Boy that gives the little Rabbit his final form, but the memory of that love. It is the memory of that love, again, that unites the Boy and the wild rabbit in the final lines of the story. And this remembering makes clear the function of the toy in this narrative, and, I argue, in all toy narratives: toys are made to remember.

Toys are emblematic of memory, specifically of childhood memory; they do not just evoke memories of childhood, but also contain them (on behalf of the adult author as well as the forgetful and abandoning child character). Like child characters within children's texts, toy characters share perhaps even more obviously in the project of conscious memorymaking that is so important in the genre. More than simply working to reflect adult memory, toy characters work to engender memory in the child reader. In Pierre Nora's terminology (applied to children's literature by Valerie Krips), toy characters are lieux de mémoire (or "sites of memory") "sites at which [...] there is an intention to remember" (Krips, The Presence of the Past 17). As such, toys mirror the larger project of children's literature, and "the complexities of adult remembering" (32) at the heart of its production:

Children's fiction marks the pressures and realignments of dialectic engagement as it responds to adult memory and to childhood understood in terms of a personal and collective past. At the same time, it gives an account of the present for an implied audience of child readers for whom such memory, and the collective past it represents, cannot exist. The situation of a children's book is thus peculiar in its temporal reference, which is both to the present and past, to memory and the promise of a memory. (The Presence of the Past 25)

The role of mourning here is crucial. The act of remembering implies the location of the thing remembered in the past; it implies present absence. And absence (actual and impending) is central to toy narratives. In order for the toy characters in children's fiction to work as they do - as vessels of sentiment and memory - a leaving-behind is required, in 
prospect if not in fact. Toys, depending on the materials from which they are made, are certain to outlive (so to speak) their use. The spectre of abandonment colours their narratives, even as they describe present "summer days" of closeness and belonging. And the abandonment is inevitable whether through carelessness, or accident, or simply through the loving child growing up and away. As much as they depict present connection and belonging, toy narratives cannot help but consider the idea of an afterwards.

The shadow of the future - of the future's inevitable change which is a synonym in children's literature, given how childhood is constructed, for the future's inevitable loss - lies even over the small empire that is the 100 Aker Wood in A.A. Milne's Pooh books (WinnieThe-Pooh, published in 1926, and The House at Pooh Corner, published in 1928). The various tales - the time that Pooh was stung by bees in his guise as a black cloud; the time everyone went to the "North Pole"; the time that Eeyore lost his house, or that Piglet encountered a heffalump - are told in cohesive but discrete chapters. The book is highly episodic, and the phrases "one day," "one fine day," and the like are repeated often. This structure serves to emphasise the sense of cyclic or iterative time that gives Winnie-ThePooh its never-ending presentness, its sense of eternal summer (despite the rain, and even snow, that appears numerous times in the tales and illustrations). Given how the Pooh books work overall to create this cyclic time and to minimise the impression of its inexorable forward march, it is even more striking that The House in Pooh Corner concerns itself almost entirely with the anticipation of loss.

The House at Pooh Corner explicitly foreshadows and addresses the growing sense among the toys in the 100 Aker Wood that "Things Were going to be Different":

Christopher Robin was going away. Nobody knew why he was going; nobody knew where he was going; indeed, nobody even knew that Christopher Robin was going away. But somehow or other everybody in the Forest felt that it was happening at last. (159) 
Lois Rostov Kuznets notes in her study of toy narratives, When Toys Come Alive, that it is "Wordsworth's vision of school in the lines "Shades of the prison house begin to close / Upon the growing Boy" [that] is played out explicitly in The House at Pooh Corner" (52). The question of "what Christopher Robin does in the mornings" (Pooh Corner 71) hangs over the opening chapters in the form of Christopher Robin's absences and arrivals. We do not see him in the Forest, but returning to it. In chapter five, "In which [...] we learn what Christopher Robin does in the mornings," Rabbit knocks at Christopher Robin's door, and we see the Forest momentarily held in suspension waiting for him to respond ("he stopped and listened, and everything stopped and listened with him, and the Forest was very lone and still and peaceful in the sunshine" (74)). But Christopher Robin is not at home. Instead, Rabbit finds his note:

\section{GON OUT}

BACKSON

BISY

BACKSON

C.R. (75)

The rest of the chapter involves Rabbit, Owl, Piglet and Pooh puzzling over the meaning of it, until it is Eeyore who tells them: "He learns. He becomes Educated. He intigorates (sic) [...] Knowledge" (87). With the appearance of a new note the next morning, faintly ominous in its correct spelling ("GONE OUT / BACK SOON / C.R." (88)), it becomes clear that Christopher Robin's absences will increase, and eventually become permanent. It is a straight line from this note to a future in which Christopher Robin won't be able to "do Nothing" anymore - or, as he tells Pooh: "not so much. They don't let you" (Pooh Corner 175). Tellingly, it is Christopher Robin's increasing ability to write that signals his movement away from the enchanted wood and the toys that inhabit it, which speaks directly to the position of the adult writer of the fantasy in relation to the childhood that the 100 Aker Wood represents. It is a childhood that is constructed around wordplay and comic misunderstanding (witness the case of "the Spotted and Herbaceous Backson" (Pooh Corner 88), based on a misreading of 
Christopher Robin's first note), one that fades with increasing knowledge and context. It is also a childhood constructed as eulogised, framed in anticipated retrospect. Over the last chapters of The House at Pooh Corner - when Christopher Robin is gradually leaving, but not yet gone forever - it is pre-emptively mourned.

As in The Velveteen Rabbit, memory and forgetting are major themes of the Pooh books. This preoccupation begins as early as the introduction of Winnie-The-Pooh, in which the workings of memory are both underscored, and shown to be failing: "we can't remember whether Winnie is called after Pooh, or Pooh after Winnie. We did know once, but we have forgotten" (x). The most important thing to note here is the shifting and ambiguous "we" (encompassing who? The author? The narrator? Christopher Robin? (Christopher Robin, the character, or Christopher Milne, the boy?) Does it include Pooh himself? The other toys?). This type of conflation and identification characterises the narrative and the way that memory works within it. Christopher Robin (as a character) is identified with the toys (especially with Pooh, who at the beginning of the book wants to hear a story "about himself. Because he's that kind of bear" (Winnie-the-Pooh 2). This is a direct expression of Christopher Robin's wish to hear a story about himself). Pooh is the persona behind which Christopher Robin hides his own confusion or lack of knowledge when he interrupts the narrative at various points to ask for explanation ("Winnie-the-Pooh wasn't quite sure," he assures us (Winnie-the-Pooh 3)). Further, Christopher Robin is conflated with the narrator in ways that emphasise the two-pronged constructions of memory that are the work of the story. This excerpt depicts a kind of co-writing, and a shared construction of memory:

"And didn't I give him anything?" asked Christopher Robin, sadly.

"Of course you did," I said. You gave him - don't you remember - a little - a little $-"$

"I gave him a box of paints to paint things with. [...] Yes, $I$ remember," said Christopher Robin. (Winnie-the-Pooh 80)

This is an intradiegetic demonstration of the larger mechanism that Krips sees as characterising storytelling for children, in which adult memory imaginatively "intersects 
with, and in part attempts to constitute, the memory of the child reader" (The Presence of the Past 32).

In the last chapter of The House at Pooh Corner ("In Which Christopher Robin and Pooh Come to An Enchanted Place, And We Leave Them There"), it is established that this communal memory making stretches as far as the toy characters in the book, particularly Pooh, and it is turned directly to the larger function of the toy character in these narratives as a sort of memory box, a resting place for childhood. Christopher Robin and Pooh go on a "doing-Nothing" ramble, and come to an enchanted place called Galleon's Lap. There, Christopher Robin dubs Pooh a "faithful Knight," and charges him with the task of returning and remembering, when the future arrives in which Christopher Robin can no longer do Nothing: "Pooh, promise you won't forget about me, ever. Not even when I'm a hundred" (Pooh Corner 176). This, as in Velveteen Rabbit, is toy as memory-keeper and toy as consolation in the face of inevitable loss. And the consolation goes in two directions: it reassures both the boy that Christopher Robin will no longer be, and the bear that he will have loved, once, that they will both be mourned on their passing. Toys abide. Pooh will indeed be Christopher Robin's faithful Knight. Toys are left, however, which leads to the sense of mourning-to-come that pervades the last chapters of Pooh Corner. "[Pooh] wondered," we are told, "if being a faithful Knight meant you just went on being faithful without being told things" (Pooh Corner 174). The answer, eventually, is yes.

These are toys invested with feeling, objects animated by desire, onto which personal and cultural feeling is displaced. This displacement, or second-hand feeling, endows the toys with their own peculiar sense of an ending. Given being by loving attention and by the workings of belief and investment by the author, by the child protagonist, and indeed by the child reader, the toys in the Pooh books and beyond are dependent on the fleeting childhood of which they are symbols and totems. Milne's final image - that of an "enchanted place on the top of the Forest [where] a little boy and his Bear will always be playing" (Pooh Corner 176) immortalises the Bear as much as the boy, even as it also contains the image of a 
Christopher Robin who will never set foot there again. Like the child in the text, Pooh is constructed as both eternal and fleeting, memorialised, absent even in his presence.

Kuznets notes that "toy characters are no more or less real than human characters in literature" (When Toys Come Alive 6). That is to say, in literary terms, both human characters and animated toys (or indeed anthropomorphised animals) are constructed in exactly the same way: they are in all cases the mutual creation of author, reader, and text. They depend on an animating desire outside themselves, and are given being by a certain investment of belief. Put another way, Christopher Robin, tiny king of his domain, fixerupper of scrapes, and calmer of ruffled toy souls, is exactly as imaginative a creation as befuddled Pooh, anxious Rabbit, terrified Piglet, melancholy Eeyore, exuberant Tigger, or pompous Owl. This point becomes especially important in toy stories such as Russell Hoban's The Mouse and His Child (1969), in which there are no child characters of note with which to align the toy characters.

Indeed, the world of the mouse and his child is one that is set apart almost entirely from the human world, for all that there is evidence all over the places they pass through of the things that humans have thrown away. This story, like Velveteen Rabbit and Pooh Corner and many other toy narratives, is a story of the "Hereafter of rejected toys" (Kuznets, When Toys Come Alive 171), the story of what happens to toys after people are done with them. The only human of any real note is the unnamed Tramp, himself a marginal figure in human society. Even before the mouse and his child set off on their "search to be selfwinding, to be able to choose and to work out [their] own destiny and to win and defend [their] own home territory" (Lenz 68), they are very much on the margins of human community: they are Christmas ornaments, brought out by adult hands to be wound up and looked at by children, and packed away in the attic for the rest of the year. The rules of clockwork by which they live - "No talking before midnight and after dawn, and no crying on the job" (Hoban 6) - emphasise the secret and separate life of toys, a life that "exists in 
closed toyshops, under Christmas trees and behind the doors of dollhouses [...] a marginal, liminal, potentially carnival world" (Kuznets, When Toys Come Alive 2).

The absence of a child character around which to revolve changes the construction of the toys in this story. The mouse child remains a lieu de mémoire, a site at which childhood with its preoccupations, joys and wishes is imagined retrospectively and stored both in trust for the future, and as a bulwark against it. But in The Mouse and His Child, it is not the memory of a particular, representative childhood that is contained on behalf of a faithful and abandoning child. It is the state of childhood itself that (with the attainment of self-winding) is made ageless and eternal in the body of a clockwork toy.

The mouse child is never given a name, so his 'child' status is kept firmly at the surface of the text, and he is the most straightforward equivalence of toy and child yet considered. He is animated by desire and longing that is characterised by the novel as childlike. He wants a home, though he has never known one; he wants a family for himself and his father, though that too, is entirely outside his knowledge and experience. He dreams of the domesticity around which literary childhood is constructed. For all that Hoban "moves out into a world foreign to children and goes well beyond the issues of domestic relationships" (Kuznets 170), the entire forward momentum of the story, the quest that drives it, is derived from the mouse child's desire, and the "childness" (in Peter Hollindale's terminology) from which that desire springs (The Childness in Children's Books 46). It is interesting that in a novel that is in many ways dystopic, such desire, and the hope that keeps it alive, are both valorised and made innate to the child character. There is also the fact that the child's character remains separate and distinct from that of his father, despite the fact that the mouse and his child are in practical terms the same age, and undertake the grand part of the quest for a home and self-agency around which the novel organises itself as one toy, joined at the hands and moving in unison. Inside the narrative, the mouse father puts this down to the child's lack of a motor: 
"I want the elephant to be my mama and I want the seal to be my sister and I want to live in the beautiful house," the child insisted.

"What's all this talk of elephants and seals?" asked Frog.

"It's nonsense," said the father, "and yet it's not the child's fault. Our motor is in me. He fills the empty space inside himself with foolishness that cannot possibly come true." (Hoban 32)

The mouse child remains a child, even after he and his father are dropped into the dump from a height and smashed on a mountain of tin cans, after which they are repaired into separate entities, each with their own motor. His childness survives his pain and suffering, his experience of separation, and his contemplation of infinity; it survives war, the gaining of wisdom, and indeed (as in the case of the smashing and repairing) death and resurrection. This is where the toy story diverges from the animal story that is also so representative of childhood: the toy is the dream of the child unchanging, the child who will not grow or die, but stay the same. Toys, in their relative fixity and permanence, fill this desire, and in this way the mouse child, even in the absence of the loving investment of a child character, is a vessel for and of childhood memory.

It is worth noting at this point that The Mouse and His Child is concerned with windup toys run by clockwork. This is precisely the sort of mechanical toy with "things that buzz [...] and a stick-out handle" so scorned in The Velveteen Rabbit, in which such toys "were only toys and would never turn into anything else" (Velveteen Rabbit 14). In that story, clockwork toys are not built to last and be loved in a way that would make them Real. But the journey of the mouse and his child does not revolve around children, it is a drive towards agency. In this context, the tin and clockwork of mouse and child are made virtues; their tin durability ensures their survival. The mouse and his child are set apart from the animals they encounter by the relative hardiness of their material. The animal world they move through is dominated by violence and predation: the (animal) mice are "Rations" for the stoats, who are beset by weasels, who are in turn the prey of owls. Being tin and clockwork, the father and his child sidestep the food chain, and are immune from the hunger around them. Manny Rat 
calls them "nightmarishly durable" (Hoban 85); at one point, the child remarks that "[i]f we'd been edible we'd never have lasted so long" (106).

The child's childness is still and always defined by and against mortality, however, and death shadows the mouse child and his father, despite their existence beyond the concerns of eating and being eaten. Toys in The Mouse and His Child can be killed, and live under the threat of destruction. This is made clear in the case of the hapless windup donkey (already maimed, one-eyed, three-legged), a pawn in the foraging army of the villainous Manny Rat: "[Manny] picked up a heavy rock, lifted it high, and brought it down on the donkey's back, splitting him open like a walnut. 'Put his works in the spare-parts can'"(Hoban 19).

The child and his father move through this dangerous and deadly world, and their transformation into independent and self-winding beings ("We aren't toys anymore," the mouse father can finally assert. "Toys are to be played with and we aren't" (117)) is effected by a long, hard process of breaking down and remaking which is explicitly tied to death and resurrection. Again, it is tin durability (and the capacity to be repaired) that allows both breaking-down, and resurrection: his clockwork allows the mouse child the dream of selfwinding that grants him a kind of immortality, along with the childness he carries. And it is this immortality - this steadfastness in the face of change - that joins the mouse child to the Velveteen Rabbit and Pooh before him, for all of the differences between them. If toys are representative of the child, then they represent the child with its dynamic change removed a child who will not grow up and out of childhood, but stay and remember and contain it.

The Mouse and His Child demonstrates the particular aptness of toys as containers and representations of childhood in other ways than their relationship to death. They are small, to start with, and littleness is another of the themes that Jerry Griswold sees as defining the genre: "Only in children's literature is littleness so frequently a topic [...] juveniles seem to own the terrain of the miniature" (Feeling Like a Kid 51). Susan Stewart, in her examination of narrative nostalgia, On Longing, explains the connection between 
childhood and the miniature as one of likeness, particularly from the point of view of the adult author:

The child continually enters here as a metaphor, perhaps not simply because the child is in some physical sense a miniature of the adult, but also because the world of childhood, limited in physical scope yet fantastic in its content, presents in some ways a miniature and fictive chapter in each life history; it is a world that is part of history, at least the history of the individual adult, but remote from the presentness of adult life. We imagine childhood as if it were at the other end of a tunnel - distanced, diminutive and clearly framed. (43)

Fascination for the miniature, then, is not simply a matter of childish taste, but also a direct product of the adult memory that produces the literature of childhood on children's behalf.

The littleness of toys is the source of their particular vulnerability, "a reflection of their diminished power" (Griswold 53), mirroring the situation of children who live at the power of adults. Part of the paradoxical condition of being a toy is being at the mercy of abandonment and disposal, despite being simultaneously invested with emotion and memory (a dynamic we have already seen in the loving and abandonment of the Velveteen Rabbit). Brian Sutton-Smith notes how the word "toy" carries connotations of "fickleness and trifling, [...], as in the phrase to 'toy with someone."' (Toys as Culture 238). The toys in The Mouse and His Child are toyed with, in more ways than one. Witness the experience of the elephant after being sold and before coming to the dump:

she had endured what toys endure. She had been smeared with jam and worried by the dog, she had been sat upon, and she had been dropped. She had been made to pull wagons, had been shot at by toy cannons, and had been left out in the rain until her works had rusted fast and she was thrown away. (Hoban 27)

Sutton-Smith notes "how liable the toy is to bipolar usages (gift vs. obligation; bond vs. solitariness; isolation vs. cooperation). An emphasis in one direction seems to create its own 
antithesis in the other" (Toys and Culture 43). In this, the toy mirrors and represents children's literature more generally, which is also constructed in paradoxically simultaneous binaries. There is, for example, the opposition in cultural conceptions of children's literature between the instructive and the entertaining, and between the trivial and the sacred. The child figure itself is poised between the past and the future, the innocent and the bestial, and the living and the dead. A fitting binary in The Mouse and His Child is that between treasure and trash. Even as the toy is loaded with personal and cultural significance, it is a commodity, and treated as trifling and inconsequential. The Mouse and His Child is full of the language of advertising ("DREAMS INTERPRETED [...]. FORTUNES TOLD TERRITORIES SURVEYED. WEDDINGS PERFORMED. MODERATE FEES" (22)), and the inevitable consequence of consumption is obsolescence and waste. The toys that populate the books are themselves detritus; they live, not in a house or a garden (or indeed a hundred acre wood), but in a dump. Toys are dismissed as often as exalted, thrown away as often as kept, treated carelessly as often as cherished.

The miniature, however, is the source of the toys' fantasy and power as well of as their vulnerability. One of the characteristics of miniatures, according to Brian Sutton-Smith, is their marked contrast from the world they represent (249): in their difference, they can both mimic and defy reality ${ }^{20}$. It is at least partly the sense of otherness conferred by the miniature that marks childhood out in these stories as different, distinct, magical, even as the narratives' concern with memory-making speaks to the ultimate connection and continuity of adult and child. There is evidence, in The Mouse and His Child of the power of magical thinking, particularly on the part of the mouse child. His fervent wishes - "Maybe we'll succeed," "Maybe we'll have a lucky day" (Hoban 52) - are given the power of incantation in the text, the power to change and shape reality. In the end, the mouse child gains the mother and sister and uncles that he was sure should be his all along, along with a house and home that, like its toy inhabitants, has been forged through trial and suffering:

\footnotetext{
${ }^{20}$ In this, the miniature mirrors the larger mechanism of fantasy literature, which is precisely to mimic and defy reality to aesthetic and thematic effect.
} 
"The house's character had changed much with the fire that had wrecked it and the several stages of reconstruction that had renewed it; phoenixlike, the place seemed reborn of itself." (Hoban 114).

Finding and keeping a home (and the defending of that home from evil, in the form of Marchpane, a doll of leather, kid, and china, who would rather sit in a glass case that keeps her "safe from ever being played with" than a doll's house) are also major themes for the family of dolls in Rumer Godden's The Doll's House (1947) ${ }^{21}$. Doll stories are similar to the stories of toy animals in many ways: like Pooh Bear, and the Velveteen Rabbit, dolls in doll stories are constructed as lieux de mémoire, objects around which childhood memory accrues, and which come to represent a childhood constructed as an anticipated memory. Like the stories of toy animals, doll stories deal intimately with questions of the (actual or anticipated) "hereafter of toys," the time of bereavement beyond present circumstances, the time after abandonment. But there are also important differences: dolls are linked to houses and interiors, where bears and plush rabbits (and indeed, clockwork mice) are linked to the outdoors, to the garden, or the wood, or the dump. Where stuffed animals tend, in literary terms, to be associated with boys having adventures, dolls are aligned with girls playing houses. Perhaps most importantly for our purposes, dolls tend to be constructed in literature as heirloom objects: they are passed down in families and bequeathed in ways that stuffed animals do not tend to be. More than personal memory, dolls in doll stories are a representation of legacy. The particular kind of memory that dolls contain is linked to family history and inheritance.

This function is emphasised on the first page of The Doll's House, when Godden writes of the main doll protagonist, Tottie Plantaganet:

At present, she lives in the nursery of two little girls called Emily and Charlotte Dane. I say "at present" because Tottie had lived a long while; once she had lived

\footnotetext{
${ }^{21}$ Both The Doll's House and Impunity Jane by Rumer Godden were originally published in separate volumes. In this thesis, however, I am citing both stories from a collected edition of Godden's doll stories: The Fairy Doll and Other Tales. The titles are italicised in the main text, and cited using inverted commas for this reason.
} 
with two other little girls who were Emily and Charlotte's great-grandmother and their Great-Great-Aunt Laura. (Godden, "The Doll's House" 5)

Little Emily and Charlotte are both aware of Tottie's history, and they reassure each other with it:

"Tottie has been ours always," said Emily.

"Even before always," said Charlotte. (10)

Tottie is hard and resilient, made of good strong wood, and as Kuznets writes:

"Godden relies to some extent on the material substance of the individual dolls as a metaphor for their basic characters." In Tottie's case, "Godden builds on accepted ideas about the sturdiness and durability of wood" (When Toys Come Alive 114). And Tottie is indeed sturdy and durable; she contains over a hundred years of memory. At the beginning of chapter six, Emily and Jane are examining a sampler made by their Great-Grandmother as a child, which itself contains a memento mori ("Content, please God, my time on earth to dwell / Till death shall claim me and I say farewell") when Tottie chimes in: "I remember those $f$ 's [...]. They gave her a great deal of trouble" ("The Doll's House" 42). This demonstrates not only Tottie's great age, but also highlights her role as keeper of the memory of that long-dead child. Again, toys in all of these stories are things that remember as well as things remembered. The toy is the child not "gay and innocent and heartless" in Barrie's phrase, but steadfast and true; as faithful knights, toys keep memory safe. "Tottie had stayed the same all that time, for all that hundred years," we are told. "Does that surprise you? It is easier for dolls than children. From the moment they are made, finished, they never have to alter, they never have to grow" (14).

Tottie's good strong wood is also part of the magic that animates her:

She liked to think sometimes of the tree of whose wood she was made, of its strength and the sap that ran through it and made it bud and put out leaves every spring and summer, that kept it standing through the winter storms and wind. "A 
little, a very little of that tree is in me," said Tottie. "I am a little of that tree." She liked to think of it. (5)

Tottie will need her sap; this story is marked by the same spectre of abandonment (and the bereavement associated with abandonment) that we have seen in other toy narratives. Indeed, abandonment is also the past and present action of the book. In their efforts, for example, to afford to fix the doll's house that will save the family of Plantaganets from living "crowded together in two shoe-boxes that were cramped and cold and that could not shut" (13), Emily and Charlotte lend Tottie to a museum exhibit for a pound and a shilling, except that Tottie thinks that she is being sold. "'A pound and a shilling [...]. After a hundred years!' cried Tottie" (44-5). Her feelings of grief and despair are no less strong for being assuaged by her eventual return to the family. The museum, an institution of public and social history, is contrasted directly with the other main setting in the story, the nursery (containing the doll house), which is a site of personal history. The museum, in Catherine Butler's phrase, "has the power to preserve [...] but its art is that of the embalmer" (Four British Fantasists 51): it is no place for a doll whose business is the private, living memory of family.

The loss confronted in The Doll's House, however, is a step beyond the metaphorical bereavement of being abandoned by the growing child. The dolls lose one of their own: flighty 'mother' Birdie, made of cellulose and with a rattle in her head, is consumed by fire. The book ends on an explicit scene of mourning in which the dolls (together with Emily and Charlotte) gather in and around the doll's house to listen to Birdie's music box. There is an overt acknowledgement in this scene that dolls, despite their abiding quality, are vulnerable to accident and destruction. Dolls, too, eventually die, along with the memories they contain. But there is also an insistence on the presence of memory, on the way that the past is brought into the present by the act of remembering. This remembering allows the dolls and the children, in a communal effort, to find Birdie's presence in the house that she saved for them: "On her hat that still hung in the hall, and on her feather broom, and on her bird and on her parasol, the colours and patterns were still bright" ("The Doll's House" 127). 
There is the ever-present insistence in this scene, too, of the doll as an object that remembers, as well as an object of memory:

"I remember everything," said Tottie, listening to the music.

"Yes, I suppose you must, and for so long," said Mr Plantaganet. "Such a long time, Tottie."

Yes," said Tottie.

"Things come and things pass," said little Mr Plantaganet.

"Everything, from trees to dolls," said Tottie. (127)

There is an emphasis in this passage on the fact of mortality - everything (from trees to dolls) passes eventually - but there is also a reiteration of Tottie's longevity. This is doll as consolation, and doll as repository of the transitory and fleeting childhood with which she is aligned, even as she remains (relatively) constant. Tottie was there long before Birdie, and Mr Plantaganet, and the girls Charlotte and Emily. Chances are she will outlive all of them.

Much is made in Godden's doll stories of the relative powerlessness of dolls: "there is no power of growing in dolls," Godden writes in The Doll's House, "and [Tottie] knew that was why for instance, any live little girl, however stupid, had power over her" (14). Godden's dolls are sentient and have language, but can only communicate indirectly with the children who care (or fail to care) for them. "Dolls, of course, cannot talk," we are told in Impunity Jane, another of Godden's doll stories. "They can only make wishes that some people can feel" ("Impunity Jane"453). The passivity and abjection of this wishing is emphasised in The Doll's House, too:

It is an anxious, sometimes a dangerous thing to be a doll. Dolls cannot choose; they can only be chosen; they cannot 'do'; they can only be done by; children who do not understand this often do wrong things and then the dolls are hurt and abused and lost; and when this happens dolls cannot speak, nor do anything except be hurt and abused and lost. ("The Doll's House" 6-7) 
This moral is represented in The Doll's House by the past of Mr Plantaganet, who had, before coming to the nursery of Emily and Charlotte, been hurt and abused and lost: "they threw him into a cold dark toy cupboard, where he lay for weeks and months and might have lain for years [...] his eyes were filled with dust"(7-8). He remains damaged by this cruel treatment: "there was still something of the dark toy cupboard about Mr Plantaganet" (10).

The plight of the doll protagonist in Impunity Jane: The Story of a Pocket Doll (1955) is somewhat similar to that of Mr Plantaganet in its echoes of burial: she sits, neglected, on a bead cushion in a doll house, where "[e]verything was covered with dust, even Impunity Jane. She had felt it settling on her, and it made her miserable" ("Impunity Jane" 456). There is the same emphasis in this story that we find in The Doll's House on the doll as invested with family history, and the doll as an object of inheritance. Impunity Jane was bought "many years ago, when the streets were lit with gas and boys wore sailor suits and girls had many heavy petticoats" (451); she spends over fifty years being passed down - with the beaded cushion she sits on, and the doll house in which she sits - through successive generations of a family who likes to endow their daughters with names beginning with E. She is owned in turn by an Effie, an Elizabeth, an Ethel, and an Ellen. Life in the doll house does not suit Impunity Jane, whose orientation towards the outdoors is made clear from her beginnings in the toy shop: "She sat on the counter near a skipping rope, a telescope, and a sailing ship; she was quite at home among these adventurous toys" (451). Sturdily constructed ("why, you could drop her with impunity" (452)), Jane longs not for security, but for experience. The doll house here is not a symbol of safety, but of stifling; throughout the story Jane hears and feels what she calls a "bugle-call" to bravery and adventure, a call to outside.

For Impunity Jane, Gideon, the boy who spies her in his cousin Ellen's doll house and steals her, is an answer to prayer - or rather, an answer to the wishing that lies at the centre of the relationship between doll and child as Godden imagines it. As mentioned above, wishing is a tenuous power, and often ineffective: Impunity Jane spends over fifty years 
wishing in the direction of children who cannot feel or heed her wishes. Wishing is also intrinsically connected to a state of loss or lack: wishes are not born of contentment, but of a desire not met. This depiction of wishing (and its concomitant lack) is certainly a comment on relative power that can be applied to the doll, to the child of which the doll is so often a representation, and even to the girl, as dolls are so routinely gendered (boy dolls are called "action figures"). But wishing in Godden's work, as Kuznets writes, "proves itself a subtle yet potent force" (When Toys Come Alive 111), and Gideon answers Jane's call.

The relationship between Impunity Jane and Gideon is characterised by the same bruising and slightly destructive affection that marks the traditional bond between a boy and his toy in stuffed animal stories, and this is apt for a tale about a doll who belongs anywhere but inside a doll house. Over the course of the story, Impunity Jane skates, scoots, climbs trees, and goes down holes; she is sent up in toy aeroplanes and balloons and pushed off in ships; she is even tied to a Catherine Wheel, and "escapes without hurt" ("Impunity Jane" 451), just as her name insists. She emphatically avoids the doll house, and instead plays in "igloos and wigwams, ranch houses, forts and rocket ships" (464). Like the Velveteen Rabbit, she is loved into battered and adored ugliness. Her real home is Gideon's pocket, which she shares with "strings and corks, sweets and sweet-papers, nuts, cigarette cards with beautiful pictures, an important message, a knife with a broken handle, some useful screws and tacks, a bit of pencil, and, for a long time, a little brown snail" (459). She is incandescently happy there, especially given that Gideon's pockets often had real holes, and Impunity Jane "could put her head right through them into the world" (458).

In a story that reverses its gender terms so neatly (Impunity Jane is the story of a boy and his doll), the implications of gender construction here are somewhat old-fashioned and troubling. Impunity Jane's desire for excitement and adventure - her desire for outside - is equated with a desire for boyhood, or at least for the version of boyhood endorsed by this narrative, a boyhood of knives and catapults, of mud, pet snails (puppy-dog tails), and "warm dirty fingers" (466). All the girls in the story are tied to the indoors - Elizabeth sews, 
Ethel is bookish, Ellen prefers the television - and, more damningly, they are all characterised by a boring conventionality of mind that deafens them to Jane's calls to adventure. Over her fifty years on the bead cushion, Jane looks out of the window at a succession of adventurous brothers - one with a train, another with a hoop - and longs for the outside. It takes Gideon, a boy, to even think of taking the inside out: "Can't we put the doll's house up a tree?" he asks. "Let's put it on a raft and float it on the river" $(456,457)$.

As is characteristic of the toy-child relationship in children's literature, the relationship between Impunity Jane and Gideon is haunted by its ending, and this sense of fleetingness and finiteness is paradoxically bolstered by the cyclical and iterative description of their shared adventures. It turns out that contemplating the loss of her relationship with Gideon and the freedom it grants her is the only thing that can threaten Jane's muchvaunted impunity. At least at first, the threat of loss arises from the story's treatment of gender: "The worry was this. Gideon was a boy, and boys do not have dolls, not even in their pockets" (459). When Gideon is cornered by Joe and his gang, and Jane worries that Gideon will deny her or lose her after the gang finds a doll in his pocket and calls him a 'sissy,' she fears physical destruction in a way she never does while adventuring. "'Will [Joe] throw me in the gutter $[. .$.$] ?' thought Impunity Jane. 'Will he put me down and tread on me? Break me$ with his heel?"' (463). As it turns out, Jane (not as a doll but as a "model" (or action figure?)) is Gideon's ticket into Joe's gang: she is a source of power and social connection for him. The only other time in the narrative that Jane's impunity falters is the only other time that her relationship to Gideon is threatened, but this time the threat is entirely emotional, and the emotion is grief at loss and separation. Gideon had saved Jane from her stifled and static existence on the bead cushion in the closed doll house with an act of theft. He stole her from his cousin Ellen. He is wracked by guilt over his theft, and the guilt slowly grows. Jane feels Gideon's unhappiness ("if dolls can make you feel," we are told, "you can make them feel as well" (459)), and in order to save him, she wishes to be returned to the doll house: 
"I can't go back," said Impunity Jane, "I can't!" But from far off, she seemed to hear the bugle telling her to be brave, and she knew she must wish, "Gideon, put me back."

She wanted to say, "Gideon, hold me tightly," but she said, "Gideon, put me back." (466)

She thinks of what she is losing: "'No more pockets [...] No more Joe, no gang, not even Puggy. No more...Gideon!' cried Impunity Jane" (467), and the sturdy, strong china she is made of cracks in place of her heart. This is presented in the story as a real and present grief - and Gideon goes to return her the next day - but it foreshadows a later, inevitable ending, explicitly described when Gideon finds his cousin packing up her nursery:

"I'm going to give all my toys away," said Ellen with a toss of her head. "I'm too old to play with them anymore. I'm going to boarding school. Wouldn't you like to go to boarding school?"

"No," said Gideon.

"Of course, you're still a little boy," said Ellen. "You still like toys." (467)

While Ellen's outgrowing of her nursery allows for an immediate happy ending (she offers Gideon a toy and he becomes Jane's legitimate owner, allowing her to stay in his pocket for the storybook version of happily-ever-after), it casts a shadow over the future in the shape of a child who packs up her toys to give them away. In doll stories with dolls who are constructed as sites of generational memory, as here, this sense of inevitable passing is made even more acute. Jane has seen fifty years of owners come and go; she will remain long after Gideon is gone. The terse ending of the story, which describes the fate of the doll house and the beaded cushion that were Jane's prison for so long, is nominally happy in that it removes their threat to her. From another point of view, it comments on how easily toys (even legacy items and heirlooms) can be discarded and disappear:

As for the dolls' house, it was given away.

As for the bead cushion, it was lost. (468) 
Dick King Smith's Lady Daisy (1992) continues the gender reversal found in Impunity Jane, in that rather than being the story of a boy and his Bear (or a Boy and his velveteen rabbit), Lady Daisy is the story of a boy and his Victorian doll. But the dynamics of the two stories are quite different: where Impunity Jane rejects the role of the Doll in the House in order to find happiness with her Gideon, in Lady Daisy, it is nine-year-old Ned who adapts to his doll, however much embarrassment his need for her secretly causes him.

Ned's attachment to Lady Daisy is extremely potent, potent enough to override Ned's anxiety about what owning a doll makes him look like. Interestingly, he is comfortable with having her and with wanting her - it is being seen to want her that is the sticking point. He hides her for a time, from his father ("It's just that dad would expect me to have the kind of [...] [toy] that most boys would have. Some kind of action man, like Rambo, or a funny animal like Garfield and Kermit. If he know about you, he'd think I was a wimp" (King-Smith 65)), and from his friends at school. But Daisy's increasing exposure (at home, and at school when he displays her as part of a project about Victorian history and culture) serves to make Ned stronger rather than weaker. As much as Lady Daisy is Ned's mentor, sometimesteacher, and loyal and devoted friend, one of her most important functions in the story is to allow Ned the role of faithful Knight on her behalf. On seeing her picked up and shaken by the biggest bully in the school, Ned bloodies the bully's nose and leaves him crying. The fisticuffs at school make Ned a man in the eyes of his (trapped-by-the-patriarchy) father, as well as in the eyes of Daisy herself. In this way the doll works to affirm and reinforce Ned's masculinity in his role as her physical protector and defender. Unlike Impunity Jane, much is made of Daisy's physical fragility - like her original "dollmother," Ned's great-great-Aunt Victoria, Daisy's "constitution is delicate, and care needs to be taken of her health" (KingSmith 19).

Lady Daisy (a doll of lively mind belied by the rigid expression on her wax face), is no girlish adventurer: far from being characterised as a girl, she is an old woman. "[N]o one could call Lady Daisy a child," Ned tells the reader, along with himself. "She might look like 
one, with her plump pink cheeks and her baby-blue eyes, but really she's a woman, a wise little old woman" (King-Smith 55). She has an old woman's speech patterns and outlook, and as the older and wiser of the pair, Daisy acts as mentor and advisor to Ned. She treats him with a fond kind of condescension: she calls him "dear boy" and soothes his ruffled feathers with a particularly aged perspective. "The time will soon pass," she tells him, on learning of his worry at a week-long separation from her. "Time does, I can assure you" (King-Smith 72).

This characterisation recalls the hundred-year perspective of Godden's Tottie rather than the perpetually girlish adventuring of Impunity Jane, and it highlights the knowingness of dolls in this literature, which is set up in direct contrast to the curiosity, wonder, and befuddlement of stuffed animals. It also highlights the great age of literary dolls in comparison with rather shorter-lived animal toys, and their literary function as a tangible connection to generational history within a family, and thus as a tangible symbol of the relationship of childhood to time.

Daisy is not just an old woman, but a Victorian old woman (she was laid in the box where Ned finds her shortly after the death of "our great Queen-Empress" in 1901 (KingSmith 15)). She is characterised by her Victorian opinions: about the appropriate role of women in public life (she is scandalised by Thatcher); about propriety in dress (there is a lovely scene in chapter eleven where Ned's mother begins to take off Daisy's dress to wash it, and Ned is forced to leave the room in an agony of embarrassment); and about the French, towards whom Daisy's feelings are venomous. Her value to Ned as an historical resource is made clear by the history project that Ned and his classmates are doing at school about Victorian times: "as the project progressed, Ned's pieces of writing and Ned's pictures and Ned's poetry [...] were far and away the best in the class," thanks to Lady Daisy "giving him the benefit of her knowledge" (King-Smith 69-70). Forging a connection to the past, through and beyond the doll that is a relic of it, is the book's, and indeed the doll genre's, larger theme. The doll, in particular, is constructed as a souvenir, an object which "lies at the threshold of the material and the ideal" (Rosenthal 132). A souvenir is both a memory in 
itself and a container for other memories: the doll remembers both particular childhoods, and also childhood as a larger state of being. The toy as souvenir is part of the project of conscious memory-making - indeed, memory gifting - that is the function of the literature of childhood as a whole; a project that finds its source, as so much in the genre does, in the generative gap between the writing and remembering adult, and the reading and imagining child.

This gap manifests itself in the peculiar nature of the memory being engendered in these stories, one that I have already mentioned: it evokes both the actual memory of the adult and the anticipated memory of the child. Lady Daisy, for Ned, is more than a presence, she is also a memory-to-be, oddly proleptic in nature: the book is characteristic in its contemplation of a future past, a time beyond the strong connection between Ned and Daisy. Daisy can only be heard by her child companion, and not by any surrounding adults, however well-disposed towards nursery magic they are. Daisy warns Ned of this future past outright: "We will still have time to talk together, for you will not be grown up yet awhile. But one day the magic cord between us will snap, and then you must put me to bed in that charming cot, and leave me there, to sleep until another child wakes me" (King-Smith 154).

The shadow of endings, in the forms of loss and mortality, haunt this book as they have all the other toy stories being considered. Lady Daisy contemplates the potential death of the doll, as well as the death of the child-bond. Daisy's physical fragility is mentioned above, and her potential destruction is a major source of anxiety for Ned, as well as the motif that drives the plot forward: Ned, in his role as "dollkeeper as well as goalkeeper" (KingSmith 53) saves her not just from the bully, but also from the jaws of a dog, and from being run over by a van ("You have looked after me, fought my battles, saved me indeed from certain destruction" (154), Daisy tells him). Ned must even protect Daisy from his own physical exuberance: after he slides down the bannister holding onto her, his Gran warns him, "Supposing you'd dropped it? It's a wax doll, you know, its head is only made of hardened beeswax, it would have smashed to bits on the floor" (43). Afterwards, Ned is 
haunted by "dreadful pictures, of Lady Daisy lying with a fractured skull, the blue eyes closed, never again to open, or worse by far, of a headless corpse amidst smithereens of broken beeswax" (45). Daisy's death is called into explicit question - "you cannot die, said Ned to himself, and then, remembering Gran's warning, or can you?" (47).

Possible destruction is only one of the intimations of mortality that surround both the doll, and through her, Ned. Daisy is only found, after resting for 89 years in a shoe box tied with string, because Ned's Gran follows through on her very long-held intention to clear out her boxes: "I keep saying to myself, I must do it before they put me in my own one" (KingSmith 11). From the first, then, Daisy and Ned's beginning is set alongside Gran's end. Ned is mildly outraged by Gran's easy equivalence of cardboard box with coffin ("Oh Gran!"), but his grandmother is stoically matter-of-fact ("Comes to us all," she says). Daisy - in the state of non-being or suspended animation that comes over her when she is laid down with her eyes closed - went to sleep wearing a black velvet armband as a sign of public mourning for the death of Queen Victoria in 1901. On waking, she must be told how long it has been since she was put away, and also that Daisy's own Victoria, her beloved dollmother, delicate of constitution and blonde of ringlet, died the same year as the Queen of scarlet fever at the age of five. Again, the doll is linked outright to the dead child. Ned is bound up in these mortal notes: he is charged with telling Daisy of Victoria's death, with helping her grieve, and then with putting Daisy back to sleep when his time with her is over. In this last there is the death of childhood, the future abandonment that these stories treat so closely. It is Gran who calls Ned's attention to the fleeting by telling him that in twenty years (2010 in the narrative chronology), Ned will be grown and his own daughter will be playing with Lady Daisy. Ned finds this hard to fathom:

"Oh, go on, Gran! How much do you want to bet?"

"Not much use me betting," said Gran. "I'll be in my box by then. But you just mark my words, pet, and remember that date. 2010." (King-Smith 156) 
Gran is proven right: the epilogue of the story, titled 17/o6/2010, is set twenty years later. Ned, grown and drinking coffee, looks at the date and remarks how time flies. He gives Lady Daisy to his own four-year-old daughter on the second anniversary of his grandmother's death, cementing the link between Daisy's beginnings and Gran's end. Ned's passing on of Daisy to his own daughter underscores Daisy's role as an executor of family history and legacy: like the family home of his grandmother, Daisy is "entailed" to Ned, not to be sold or given away, but kept in the family. This inheritance is part of the consolation of the story, which emphasises continuity as much as it insists on passings-away. As Daisy warned Ned when he was little and could not imagine the magic cord between them snapping, "[y]ou will not lose me, I shall still be with you, and once you are older you will find, I think, that the moment will be not be too hard to bear" (King-Smith 154). When Daisy is woken by Ned's daughter, named Victoria for the great-great Aunt that was Daisy's first dollmother, Ned cannot hear or speak to her anymore. But he tells his daughter to give Daisy his love. Daisy will tell Ned's daughter stories of Ned, as the keeper of his history, just as she did for her first dollmother, and as she will for her newest Victoria, when the time comes.

Perhaps that is the note to end on: that memory stretches in both directions, and implies a future as well as a past. The toy character is "the thing," in Jean Baudrillard's phrase, "with which we construct our mourning" (cited in Krips, Presence of the Past 93), mirroring the literature in which it appears in the way it both constitutes and represents childhood and childhood memory as eulogised space. But in its role as "talisman for memories" (Kuznets, citing Carl Fox, When Toys Come Alive 5) and lieu de mémoire, the toy belongs to the future at least as much as it does to the past, and toy stories are as much about the adult that will one day be, as they are about the child that once was. In this way, toys and their stories assert continuity as well as loss. 


\section{Chapter Four}

\section{Haunted and Haunting: Ghost Stories}

and the grave

Proves the child ephemeral

W.H. Auden, "Lullaby"

As we have seen, stories of the child in relation to the animal and to the toy demonstrate the intimations of mortality that are so prevalent in childhood as it is written in children's literature. The animal is representative of an intense, threatened, and short-lived vitality; the toy is a container for childhood memory: both genres construct the child, by identification and close association, as eulogised, as defined even in its presence by an impending future absence. This eulogising impulse is a direct result of the gap at the centre of children's literature between the remembering adult and the child who will one day be the remembering adult, and it rises to the surface of plot and theme in stories that align the child with ghosts.

The children's ghost story is part of a larger literature of terror that has always been fundamental to children's reading. Of course, fundamental is not the same as sanctioned: the question of whether the supernatural is appropriate to children's literature has historically been a flashpoint in the larger debate about the proper role of fantasy in the genre. Indeed, in the eighteenth century, at the time when a dedicated literature for children was beginning to be established, children's literature was framed in accordance with Lockean ideology, "carefully to keep Children from frights of all kinds when they are young" (Some Thoughts Concerning Education 171). It was framed, that is to say, to deliberately exclude the Gothic:

culturally approved forms of children's literature became everything the Gothic is not. In a ceaseless dialectic of action and reaction, the ghost is vigorously stamped out of children's literature in the same decades that witnessed the consolidation of 
not only the Gothic aesthetic, but a firm sense of what constituted the middle-class child, his education, and his books too. (Townshend, "The Haunted Nursery: 17641830," 21).

It is crucial to note, however, that this effort to define and delimit "culturally approved" children's literature was itself a reaction to what children were already reading and interested in. It was in reaction particularly to "the chapbook or penny history, a particular form of street literature" with an "almost characteristic leaning towards the horrific, the dreadful and the ghostly" (Townshend 19). The fortunes of fantasy in children's books turned with increasing Romantic valorisation of childhood for its imaginative qualities among the Victorians and Edwardians, but the current resurgence of gothic tropes in "culturally approved forms" of children's literature is very much a twenty-first century phenomenon. The arrival of the Harry Potter books in the 1990s changed the landscape of children's books profoundly. In 2008, the editors of The Gothic in Children's Literature were able to claim, persuasively if not quite comfortably, that "in children's literature today, the Gothic is mainstream" (1), and this generic dominance has only increased in the years since.

There are a number of reasons the Gothic has always found a ready, if not always sanctioned, place in the literature of childhood. One is that, for producers of children's literature, gothic tropes such as ghosts play into the same culturally ascribed (and more than slightly dissonant) Romantic qualities that are used as a basis for the argument that children are a fitting audience for fantasy. Children are imaginative; children are unconstrained by experience; children are open to the supernatural and the special kinds of truth that the supernatural conveys. From only a slightly altered perspective, these qualities can be phrased differently: children are gullible; children are irrational; children do not yet know better. Culturally, monsters have always hidden in the nursery, usually under the bed. Romantic conceptions of the terrible and the sublime find a particular resonance in the terrors of childhood, a childhood that is itself figured simultaneously as a site of nostalgia for 
a natural and lost authentic relation to the world, and as a site of the fearful and dangerous innate monstrosity that is countered by (adult) civilization.

This leads directly into a second reason the Gothic and the literature of childhood make instinctive companions: they revolve in many ways around the same points of tension. The Gothic, according to David Punter and Glennis Byron, functions "to establish a set of polarities revolving primarily around the concepts of the primitive and the civilised" (The Gothic 3), in which the "primitive" is figured as "the barbaric and the uncivilised" on the one hand, and as "the true, but lost, foundations of a culture" on the other (5). These are the precise tensions of which the child and literary childhood are so powerfully emblematic.

Gothic writing, and the ghost story in particular, focus perhaps above all else on a reckoning with the past. Jarlath Killeen writes in History of the Gothic that "[i]t has long been recognized that Gothic is in many ways a grappling with the forces of time and history" (27); the Gothic has been called the "perfect anonymous language for the peculiar unwillingness of the past to go away" (Sage and Lloyd Smith 4). Writers of childhood, precisely because of the necessarily retrospective, self-reflective nature of the generative gap between the adult author and the child reader, must inevitably deal with these Gothic concerns, and with the ambivalences of personal and cultural inheritance.

These are some of the forces at work in Neil Gaiman's The Graveyard Book (2008), a story that blurs the boundary between the child (as a symbol of vital presence), and the ghost (as a "manifestation of the 'past-in-the-present"" (Killeen 128)). The Graveyard Book tells the story of a toddler who escapes the assassin who has slaughtered his family by toddling his way innocently into a graveyard. There he is given a name - Nobody Owens and is adopted and raised, with the help of a vampire and a werewolf, by ghosts. Nobody is portrayed as a living boy who is a subject of prophecy and thus a symbol of the future; he is also a ghost among ghosts, a symbol of the lingering past in his grey winding sheet. This doubled presentation - this alignment and identification with ghosts - inflects the construction of childhood both in The Graveyard Book and in ghost stories more generally. 
The book is prefaced by what Gaiman calls a "traditional nursery rhyme":

Rattle his bones

Over the stones

It's only a pauper

Who nobody owns. (n.p.)

This rhyme is notable because it provides a possible inspiration for the name that Gaiman gives the living boy in the graveyard, Nobody Owens, but it also, crucially, rattles bones in the nursery. There is some confusion over the source of this verse: it appears to be a slightly misquoted version of T. Noel's "The Pauper's Drive," and it is doubtful whether it is a nursery rhyme at all. Nevertheless, Gaiman's description of it as such deliberately links childhood with the graveyard. Reportedly, he was inspired in this connection by his own son: "the book was based on an idea he got while watching his son Mike peddle his tricycle happily around a local graveyard, which set Gaiman to thinking: 'he seems at home here'" (Campbell n.p.). The text of The Graveyard Book explicitly plays on assumptions to the contrary: Silas the vampire, trying to put off the predator that had tracked Nobody as far as the graveyard, claims that a baby would be incongruous there. "If there was a baby," he tells the assassin, "[...] it wouldn't have been here in the graveyard. [...] It's unlikely that a child would have come here, after all" (14). Later, when the inhabitants of the graveyard are discussing what to do with the toddler in their midst, Josiah Worthington, the patron and progenitor of the place, grumbles that "this is a graveyard not a nursery, blast it" (18). But the story works against these assumptions of incongruity. The Graveyard (capitalised in the text) is shown to be a wonderful nursery for Nobody Owens (or Bod, as he comes to be known), and Bod is perfectly at home there.

The Graveyard itself is depicted as a liminal space, an abode for the dead that also teems with life: "They declared this place an official nature reserve, you know, thirty years ago, around the time of the last funeral" (The Graveyard Book 14). Bod, whose life is preserved as long as he lives within its bounds, safe from the man who hunts him, is aligned 
with the animals who find refuge there, as well as the ghosts who make it their home. But the Graveyard is liminal in more ways than one. It is by definition a place where the living visit and interact with the dead, a place of intersection between the past and the present. It is also a place where the natural meets the constructed and the artificial: the Graveyard, for all of the nature it preserves, is full of man-made structures. There are the graves themselves (bone houses); there is a chapel with a crypt and a spire; there is an amphitheatre, and a gardener's hut. These structures are, in their age and increasing decrepitude, merging with the natural landscape. On entering the Graveyard, we are told, "[y]ou could see the abandoned funeral chapel, iron doors padlocked, ivy on the sides of the spire, a small tree growing out of the guttering at roof level" (7). The Graveyard does more than place the natural alongside the artificial and the living alongside the dead: it actively works to break down the borders between them. Further, combining the safety and the constraint of the keep, or the fortress, the Graveyard keeps Bod both protected and contained. As he grows over the course of the story, Bod finds this security more and more stifling.

Andrew Smith, in his study of the literary Gothic, writes that "the Gothic creates an uncanny mood in which characters become doubled with places," and calls this "a key element of the ghost story" (Gothic Literature 15). This doubling is evident in The Graveyard Book, in which Bod is as liminal as the Graveyard he calls home. He has been given "The Freedom of the Graveyard," a set of skills and abilities that enable him to live among the dead while not being of them. Bod can Fade, and Frighten, and Slip, and Dreamwalk; he knows the language of the Night Gaunt, but among the dead he remains separate in his aliveness. Among the living, on the other hand, he is ghostly. He "look[s] grave" (The Graveyard Book 19) even as a baby, and when he goes to school outside the Graveyard, he eludes direct attention:

No one noticed the boy, not at first. No one even noticed that they hadn't noticed him. [...] He didn't answer much, not unless he was directly asked a question, and 
even then his answers were short and forgettable, colourless: he faded, in mind and in memory. (168)

The Graveyard is in many ways written as a childhood paradise, appropriate to, and metaphoric of the child it houses; simultaneously, it locks Bod out of the world and deprives him of colour: Bod's mousy hair and his grey winding sheet are overtly contrasted with the colour and vivacity that his only living friend, the aptly-named Scarlett Amber, brings into the graveyard with her. His name, Nobody, is effectively a negation, but his nickname, Bod, evoking both Body and Boy, affirms his presence and being, and reflects his desire, which increases with age, to take up space in the world. "I want," Bod says before he leaves the Graveyard in the last chapter, "to leave a footprint on the sand of a desert island" (286).

What, then, are the implications of writing the child as ghost, and the nursery as graveyard? Connecting womb and tomb, the child as ghost places childhood in the past, and figures it as both haunting and haunted. Bod lives, in a very real sense, in history. The Graveyard that is Bod's home is old - its oldest grave is that of Caius Pompeius, buried for two thousand years - and stopped taking new burials years before Bod was born. Bod has no contemporaries, nor anyone among the ghosts who knows anything of the modern world. Silas and Miss Lupescu, who, unlike the ghosts, are capable of interaction with the world outside the Graveyard, are so marginal to that world as to be strangers to it. The ghosts who surround and teach Bod retain their particular historical languages and mannerisms, and pass them on to him: "He could greet people politely in over nine hundred years of changing manners" (175).

Living among the ghosts also leaves its mark on Bod's relationship to time, which is figured here, as in all children's fantasy, as both eternal and fleeting. Bod is subject to time, as a growing boy, but while he lives in the Graveyard, he is largely immune to its effects on his environment. For the ghosts who are his points of reference, time has ceased to mean much at all. Miss Euphemia Horsfall and Tom Sands, for example, "have been stepping out for many years," even though Tom lived and died during the Hundred Years 
War and Miss Euphemia was buried when Victoria reigned: "But the couple seemed to have no troubles with the difference in their historical periods" (163). Bod needs to be told outright that time happens:

\author{
"Time is passing, after all." \\ "Is it?" asked Bod. \\ "I am afraid so, young Master Owens." (96)
}

This ignorance of time and its effects is commonly attributed to childhood - Bod is representative both in his initial ignorance, and in his growing awareness - but Bod's Graveyard home is constructed in a way that amplifies both ignorance and awareness. Fleetingness, in this story, is provided in the figure of the man Jack, the assassin, whose mission to kill Bod before he grows up sets a metaphorical ticking clock over the space of Bod's childhood. "Time's a ticking," the man Jack is told. "You had time. Now you just have a deadline" (157). The books being considered in this thesis as representative of children's fantasy insist on casting the shadow of mortality over the children they create. In The Graveyard Book, the shadow has a particular shape in the man Jack, characterised by his darkness: "His hair was dark and his eyes were dark and he wore black leather gloves [...] his shoes were black leather, and they were polished to such a shine that they looked like dark mirrors..." (4).

Jack's pursuit of Bod is the result of prophecy. Jack belongs to a shadowy Order of Jacks, who control and shape society to their own ends, and Bod's death would forestall the end of their power:

Long time ago, [we] foresaw that one day, there would be a child born who would walk the borderline between the living and the dead. That if this child grew to adulthood, it would mean the end of our Order, and all we stand for. (253)

The prophecy concerning Bod makes clear two things: one is that Bod, like so many other children's literature protagonists, is set apart and made strange, made special, even as he is 
written as representative of childhood more generally. Like Wart, and Merlin, and Harry Potter, Bod is a chosen one; simultaneously, he is Boy, and one of many. Everyone, after all, eventually walks the border between the living and the dead. Secondly, the prophecy underlines the way that the book has reversed its gothic terms: the ghosts and monsters (Bod's particular teachers are Silas the Vampire and Miss Lupescu, the Werewolf) are friends to Bod. It is "the man" Jack, in the world of the living, who means him harm.

Death, then, is stripped of its Gothic terror in The Graveyard Book. The story separates Gothic trope from Gothic effect: living among the dead, Bod has no fear of them. The Graveyard Book insists on continuity and connection between the past and the present, the living and the dead, and this connection is embodied in the child character who moves between them. The Graveyard is strewn with epitaphs that link death to life and afterlife: Thomas Pennyworth "lyes in the certainty of the most glorious resurrection" (95); Roderick Persson and his wives Arabella and Petunia "Sleep to Wake Again" (173). The memento mori inscribed on Digby Poole's gravestone reminds the reader of the relationship to death that so closely mirrors the child's relationship to the adult: "As I Am, So Shall You Be" (152). It is telling that the climax of the book, coming almost exactly halfway through the story, is not Bod's showdown with Jack, which comes considerably later, but the Macabray: an annual event in which the normal barriers between the living and the dead fall, and the dead walk out of the graveyard and dance with the living. As is characteristic for this story, the Danse Macabre inspires not fear, but joyful connection:

The dance sped up, and the dancers with it. Bod was breathless, but he could not imagine the dance ever stopping; the Macabray, the dance of the living and the dead, the dance with Death. Bod was smiling, and everyone was smiling. (149)

This book figures life itself as a dance with death - a dance that never stops and that ends in breathlessness, and in a smiling skull. Gaiman emphasises the lack of conflict between the world of the dead and the world of the living, as separate as they are. In Bod's conversation with the Lady on the Grey (this book's particular personification of Death), in 
which he makes her promise to let him ride her horse one day, there is not fear but comfort in her answer: "Everybody does" (150).

After the Macabray and Bod's conversation with Death, the effects of time on his life increase, and the narrative pace speeds up. Jack draws closer, Bod leaves the Graveyard to go to school; the plot, marching in two-yearly episodic increments, advances to an inevitable conclusion. But the biggest sign of time's working in the book is Bod himself, slowly outgrowing the Graveyard. That The Graveyard Book is an homage to, and elaboration on Rudyard Kipling's The Jungle Books is well known - Gaiman says as much in his acknowledgements. Where Mowgli grows from animal to human, his maturation intimately tied to parting and to grief, Bod grows from ghost to human, moving, in the last pages of the book, from the night-time of the Graveyard to the sunrise of the world outside. Bod is differentiated from the dead in his potential for growth. His inability (and disinclination) to stay a child becomes clearer and clearer:

In the graveyard, no one ever changed. The little children Bod had played with when he was small were still little children; Fortinbras Bartleby, who had once been his best friend, was now four or five years younger than Bod was, and they had less to talk about each time they saw each other. (213)

Mother Slaughter, whose weathered and eroded tombstone reading simply "LAUGH [...] had puzzled the local historians for over a hundred years," tells Bod: "I called you boy, didn't I? But time passes in the blink of an eye, and it's a young man you are now isn't it?" (279-80). The break that Bod must make with his childhood in order to become somebody who can "leave a footprint" is almost total. He will never be able to see or hear his mother again, and he can never return ("If I come back, it will be a place, but it won't be home any longer" (286)). Again, this is both universal to childhood, and made particularly acute by Bod's fantastic circumstances. As it is for Mowgli, loss and grief are intrinsically linked to Bod's maturation. The ending of the book, in which Bod must leave the Graveyard behind forever, recalls the Fall with which the end of childhood is so often associated. There is an 
echo in Bod's leave-taking of the expulsion of Adam and Eve from Eden at the end of Milton's Paradise Lost:

Som natural tears they drop'd, but wip'd them soon;

The World was all before them, where to choose

Thir place of rest, and Providence thir guide (Book 12, lines 645-67)

Bod's departure from the Graveyard, like the expulsion of Adam and Eve from the Garden in Milton, is framed in terms that console. Like Adam and Eve, Bod can never return to his paradise; like Adam and Eve, Bod feels the world all before him: if there are tears, they are soon wiped. There is comfort in the story's portrayal of those not lost but gone before, and infinite potential in the image of Bod, walking out of the Graveyard (and toward, inevitably, another) "with his heart and his eyes wide open" (298).

The Graveyard Book is of a piece with other children's ghost stories in its depiction of childhood as eulogised, and of the child figure as an intensely present emblem of both the past and the past-to-be. In some ways, however, it is something of an outlier: by the time Gaiman came to write The Graveyard Book in 2008, the ghost story, while still a staple of children's genre fiction, had long since faded out of prominence in children's literature more generally. As a children's genre, ghost stories reached their peak in the 1960 s and 70s, as a part of a post-World-War-II flourishing in children's literature that critics commonly refer to as the genre's second "Golden Age."22

There are good reasons why the ghost story in particular took hold of the imaginations of children's fantasy writers in the decades after World War II. Not unlike the upheaval of the Victorian period, which opened up a gap between the way of life of the parent and the way of life of the child (a gap from which modern children's fantasy emerged), the war caused a radical cultural and generational rupture. Julia Briggs writes in her history of

\footnotetext{
${ }^{22}$ These critics include (among many):Peter Hunt ("The Same But Different: Conservatism and Revolution in Children's Fiction" 79); Valerie Krips (The Presence of the Past 25), and Catherine Butler ("Ideologies of Past, Present and Future" 259).
} 
the English ghost story that in times of social upheaval "it becomes correspondingly important to retain tradition and older ways of thinking, to remember our ghosts, if we are to maintain a sense of stability" (Night Visitors 111). And ghosts are an ideal literary mechanism for asserting continuity, as "a traditional medium of communication between the past and the present, the dead and the living" (Briggs 111). Not only does the ghost story highlight the historical function of the Gothic - what David Punter calls Gothic as "a mode of history, a way of perceiving an obscure past and interpreting it" (Literature of Terror, Vol I 52 - it also, as Briggs points out, offers "certain advantages over other forms [of historical writing] since it could present a direct, rather than a vicarious, encounter" with the past (Night Visitors 111). Depicting the past and the influence of the past in the present, and reestablishing and reinforcing felt history through the potent symbolism of childhood and hauntings, became the work of the post-war children's fantasists.

The use of the ghost as "a link with the past from which we are afraid of being disinherited or disconnected" (Briggs 112) is evident in The Ghost of Thomas Kempe by Penelope Lively (1973). It tells the story of James Harrison, age ten, and his troubles after he is targeted by a poltergeist called Thomas Kempe, who had lived and died in the time of King James I. As Bod would be, James is a boy aligned with ghosts, like Bod, he is lonely. James is characterised (very fondly) by the narrator through his intense imagination and a certain solitary self-sufficiency; he does not shun company (he has a friend called Simon, as serious and introverted as James himself), but he keeps himself to himself. He makes copious lists, and is prone to daydream: he is shown lying in bed, "telling himself a long and elaborate story about a shipwreck in which he was all the characters by turn" (Thomas Kempe 31), and later, looking up at a small barred window in the library, he "had a short retreat from real life in which he became a prisoner flung into this dungeon and left there for twenty years on a diet of bread and water" (48). James's solitariness and his intense inner dream life (in which day dream and real life shade into each other) lend a certain ambiguity to his account of events (the narrative is very tightly focused on his point of view); they also make him ripe for a haunting. 
Thomas Kempe, a "self-important and opinionated" poltergeist (123), emerges into James's life from a bottle bricked into the attic room that had been his residence in the seventeenth century, intent on continuing his life's work as sorcerer, astrologer, geomancer, alchemist, medicine-maker, and finder of lost property. His haunting of James is in large part played for comic effect (the trouble that he causes is laid at James's feet, and James spends the story cleaning up messes, being denied dessert, and being blamed for property damage), but there is also tragedy in it. Thomas Kempe's "perversity and obsession" (130) (with driving out Satan and burning witches) ends in real danger when he burns down the home of Mrs Verity, who is emphatically not a witch. Further tragedy is rooted in the poltergeist's inability to connect the past to the present; he is not evil but confused, essentially stranded in a time he cannot and will not understand. James points out that Thomas Kempe is "not in our time [...]. He's in his time, whenever that was, and he thinks like people thought in his time...." His friend Simon concurs: "It must be like waking up and discovering that everyone except you has gone mad. Like a bad dream" (65). Indeed, this is how Thomas Kempe's story ends, with a somewhat plaintive written note ("I am wearie of this towne. There are people who practise strange things and I doe not understand their wayes" (147)), and a plea to be put to rest for good ("Helpe me to goe" ((149)). James's role in the putting of the past to rest is notable, but Thomas Kempe, though he drives the plot, is something of a misdirection: despite the title, Kempe is not a ghost but a poltergeist, "a thing that exhibits itself by noise alone" (102). A thing, in other words, that fails to be quite present. Thomas Kempe is only the means by which James comes to a much more closely and deeply felt haunting: his haunting by the intensely present ghost of Arnold Luckett, age ten, who in 1853, lived in the attic room of East End cottage, where James sleeps in the present of the narrative, and was haunted by Thomas Kempe in his turn.

While excavating the rubbish pit at the other end of the apple orchard, James comes across an old diary, written by a Miss Fanny Spence, telling of her nephew Arnold and his troubles at the hand of a poltergeist: 
But the worst thing of all is that to begin with I thought poor Arnold responsible, and was quite vexed with the boy, telling the poor lad he must consider his aunt's advancing years and restrain his natural boisterousness. And now it turns out the turmoil is caused by a ghost, or rather I understand a poltergeist... (102)

In this journal James finds the belief and sympathy that he fails to find from those who surround him. This book, like the others being considered in this chapter, emphasises the enforced loneliness of haunting. The haunted child is, however benignly, estranged from the present in forging a deep connection to the past, separated from those around them by secrecy, singled out. Haunting separates the haunted from the living. There are many points in the book where James notes, at first despairingly and then resignedly, that no one will believe that Thomas Kempe is the cause of his trouble, and that even if they do believe him, they can't help him: "James felt all of a sudden very weary. [...] He was on his own, where Thomas Kempe was concerned, and that was a fact" (126). In fact, James is made ghostly in his invisibility - an invisibility that is shown to be generational, due as much to James's status as a child as to his ghostly visitors. James tells his friend Simon of a game he plays in the High Street, which involves pulling a contorted face and walking along waiting for people to notice. No one does, because "as far as most grownups were concerned, children were invisible": "For most people, children were something they were so used to seeing around, like lamp-posts or pillar boxes, that they never really looked at them"(36).

Under these conditions, it is little wonder that James connects with Arnold, a boy who was once as plagued as James is. It is Arnold who makes the past present for James:

They'd have had a good time together, with that fishing rod, and the puppy, and the sorties Arnold had made into the countryside [...]. Looking around the room, thinking of Arnold seeing the same church tower framed in the window, the same tipping ceiling over the bed, he almost felt his noisy, cheerful presence. It came as a shock to realise that it was a hundred and twenty years since Arnold had stood in this room. (105) 
And there is grief inherent in James's realisation of the distance between them:

It was something of a shock to see his room quite normal and ordinary [...]. No green and white wallpaper, no Aunt Fanny chattering on breathlessly, no Arnold watching with sparkling eyes [...].Nothing there. Just an old diary, yellow, tattered, blotched with damp. James, who was not given to sentiment, sat and stared out of the window, and a very odd lumpy feeling, like the beginning of a cold, came into the back of his throat. (106).

James actively separates Arnold from his own troubles with Thomas Kempe - "he preferred to keep Arnold for private and more unworried times" (129) - and instead, their friendship, however imaginary, is portrayed as idyllic: "James told Arnold a joke about two flies on a ceiling that he had heard at school and Arnold, a hundred years away, laughed and shouted and swung on the branch of an apple tree" (112).

The time James spends with Arnold is depicted as a particular kind of boyhood pastoral, one that carries an echo of the eternal youth of Kenneth Grahame's Riverbank in The Wind in the Willows in its "long hot summer day[s] full of river and willow trees and picnic baskets stuffed with delicacies" (Thomas Kempe 120).

Whether the link between James and Arnold is purely imaginary becomes slightly more ambiguous later on: "James walked along an overgrown lane, between margins rusty with docks [...] and before long Arnold came to join him and together they went" (127). Whether or not Arnold's presence is real, his imaginative hold on James is obsessive, and amounts to a haunting. The effect of this haunting is a personal, human connection with history, and specifically with past childhood. James has been shown throughout the story to have a particular interest in the past - indeed, the book displays an archaeological impulse that is characteristic of Lively's work in this story and beyond. Lively's children's books show a deep awareness of "living in a land where consciousness of the deep past is in constant interplay with change and contemporaneity" (Butler, Four Fantasists 32); of living in an "old 
country." This is made evident in Thomas Kempe by the number of excavations it shows in detail. James spends a lot of time digging holes, and finding traces of people long gone:

One of the advantages of living in a house which had been lived in for a pretty long time was that other people's very interesting rubbish was never far away. After an hour or so he had unearthed a whole sequence of domestic breakages, from eighteenth-century wine bottles through flowery Victorian cups to twentiethcentury Woolworth's blue and white china. (27)

James even finds bones - most likely "the remains of long-past Sunday dinners" or dog's bones, but "some at least, he thought hopefully, might turn out to be human" (27). After his interaction with Arnold, the past has a face (complete with sparkling eyes) very much like James's own, and history has mingled with memory so that he can no longer think of the long-dead without a sense of their humanity. By the time human bones are found at the official Bronze Age dig in the village, James has lost his morbid excitement entirely, and argues with a worker at the site:

"Far as I'm concerned, it’s a Middle Bronze Age primary cremation burial, with bucket urn and cremated bones."

"Far as I'm concerned, it's people," said James. (131)

James's relationship with Arnold also explicitly closes the generation gap between James and the adults around him, and connects them in shared memory: when James, while helping to put up an exhibition of local history for his school's centenary, finds a portrait of Arnold Luckett, Benefactor - "the bewhiskered face of an elderly man"(139) - he is able to find the Arnold he knows in him, and to connect him to James himself as both child and as a grown man:

Mr Arnold Luckett. A person with a gold watch-chain, giving money and things to schools. An important man. A serious man. James Harrison. Mr James Harrison. 
Arnold and James, down by the Evenlode, rabbiting and fishing and walking under trees through sunlight. (139)

One of the effects of Lively's focus on archaeology in the story is that it evokes the concept of layers. "Archaeology," writes Butler, "[is] a powerful spatial model for thinking about the past, in [its] use of depth, and particularly of strata, as a means for calculating chronology" (57). James is able to peel back the layers of Arnold Luckett, Benefactor ("People hav[e] layers, like onions," he tells us (139)) to reveal the schoolboy beneath, and is able to relate to him, indeed, to imagine himself alongside him. At the end of the story, James, having acquired through his haunting a personal connection to history, can see himself, too, as what Butler calls "potentially archaeological" (6o). Yet again, the child represents a present tense that encompasses both past and future:

Time reached away behind and ahead: back to the crusading knight and Thomas Kempe and Aunt Fanny and Arnold: forward to other people who would leave their names in this place, look with different eyes on the same streets, rooftops, trees. And somewhere in the middle there was James, walking home for tea. (158)

Lively's framing of encounters with the past as a form of excavation continues in her other major ghost story for children, A Stitch in Time (1976). It tells the story of Maria Foster, a girl who spends her summer holiday in the town of Lyme Regis, a place where ammonites or fossils inhabit the cliffs of the town "like delicate scribbling upon the clay" ( $A$ Stitch in Time 28). "The whole rock," we are told, "streamed with a petrified ghost-life" (29). While living atop and among the ammonites, Maria is haunted by a Victorian girl, Harriet, who once lived in the house and carved her initials into the table in Maria's temporary bedroom. Maria's sojourn in Lyme Regis gives her access to a sense of history, a sense that is shown to be normally, if not always, hidden in her home in London:

In the heart of Oxford Street, Maria had been startled once to see workmen lift a slab of paving to reveal, beneath, brown earth. It was as though the new, shrill street of concrete and plate glass windows had shown its secret roots. (76-7) 
It may seem strange to characterise London as new and shrill, but the comparison is made explicit in the comparison of the holiday house in Lyme Regis ("'Good grief!' said Mrs Foster. 'It's the real thing! Stopped dead in 1880"' (19)) with Maria's own house: "How very strange to be staying in a house where a great many children had grown up. In her own home, there had only been her: it was built eight years ago, and was younger, in fact, than she was" (37-8).

Maria, like James in The Ghost of Thomas Kempe, is ripe for haunting. She is displaced, she is small and quiet and unremarkable, at least from the point of view of those who surround her. "Her parents," Michelle Magorian notes in the foreword to the HarperCollins edition of 2011, treat her like pleasant wallpaper" (n.p). Maria is shown to be ghostly in her lack of physical presence, and she is all too aware of her failure to leave an impression: "people usually did forget her quite quickly, she had found. To remain in people's heads you need to be noisy, or striking-looking, or memorable in some other way, and she was not" (122). Over the course of the story, Maria's shyness and reserve, her silence, her tidiness, are portrayed as unnatural and unchildlike. ${ }^{23}$ Maria constantly tests her reality against books - "This, said Maria to herself, is what is called a drawing room, like they have in books, and I have never seen before" (20) - and this includes her concept of childhood. The gap between her internalised image of childhood and her experience of it is evident from very early on in the story: on the first page, Maria, lacking other conversational companions, explains the concept of a seaside holiday to the ashtray in her parents car24: "You go down to the beach every day and run about and shout and build sandcastles and all that" (11). It is

\footnotetext{
${ }^{23}$ There are shades here of Jane Eyre, recalling a childhood scolding by a guardian: "until she [...] could discover by her own observation, that I was endeavouring in good earnest to acquire a more sociable and childlike disposition, a more attractive and sprightly manner - something lighter, franker, more natural, as it were - she really must exclude me from privileges intended only for contented, happy, little children" (Jane Eyre 7). This quote speaks directly to how "natural" childhood is a social construct against which individual childhoods are measured; it also demonstrates the absurdity inherent in that construct being privileged over the reality of a child that for whom that disposition is not natural.

${ }^{24}$ In Maria's communion with objects there is also a kind of identification with them: this recalls James in The Ghost of Thomas Kempe likening children to lampposts and pillarboxes, so ordinary as to be invisible (36).
} 
clear, even in the image of the girl conversing silently with the ashtray, that Maria is neither a runner nor a shouter.

Instead, Maria is a reader, and a stifled and deeply imaginative thinker. Much of the emotional impact of the book comes from the gap between the reader's sense of Maria as intelligent and articulate ("Maria had quite strong opinions about a fair number of things, though she seldom mentioned them to anyone" (16)), and her failure to make herself known to those around her. Indeed, she is shown to be actively stifled, as it is revealed that her imagination, and her terror, frequently get away from her: she is "throttled into silence by her feelings" (84); she is "untidy in [her] mind" (74). Aligned with the fossils that so fascinate her, Maria's is a petrified ghost-life.

Her ghost-life - and the resulting lack of meaningful interpersonal connection - both lead directly to Maria's haunting by a dead child. Her thinking is already shown to be marked by a particularly strong kind of animism. Lacking friends, she talks not only to ashtrays, but to petrol-pumps, clocks, and a particularly judgemental cat, and ghosts, after all, are only another example of the animism (what Jerry Griswold calls the "Aliveness" (Feeling Like a Kid 2) that marks out children and children's literature. In fact, there is more than one definition of animism: while one is "the attribution of life and personality (and sometimes a soul) to inanimate objects and natural phenomena" pertinent to children's literature; another is "belief in the existence of a spiritual world, and of soul or spirit apart from matter" (OED). This second definition is the one at the centre of Freud's concept of animism, the impulse he puts at the centre of the uncanny (which is often associated or conflated with the Gothic):

We appear to attribute an "uncanny" quality to impressions that seek to confirm the omnipotence of thought and the animistic mode of thinking in general, after we have reached a stage at which, in our judgement, we have abandoned such beliefs. (Totem and Taboo, 1913, cited in Briggs, Night Visitors 16) 
The uncanny lies in the tension between "an outmoded, but not entirely abandoned belief, and enlightened scepticism" (Briggs 16). The child, poised between uninformed credulity and old enough to 'know better', is a peculiarly apt symbol of this uncanny tension, and the two definitions of animism above collide in the children's ghost story to deeply resonant effect.

The literary ghost, or the dead child, then, is brought to life and made companion to and mirror of present childhood in much the same way as the literary animal or the literary toy. Like the animal or the toy, the ghost underscores cultural attributes that align childhood and its literary expression with mortality. That this mortality is linked to the gap between child and adult, and the necessary ending that lies between the one and the other, is made explicit in A Stitch in Time in Maria's sense of endings. A conversation with the cat, which Maria seems to use to internally confront things she is ashamed of feeling (her jealousies and envies, her uncharitable thoughts about others, her anxieties about herself), reveals that Maria's obsession with Harriet (the "helpful, no-longer-here friend" (48) who once sewed a sampler on the theme of the moment of death) is actually dependent on her conviction that Harriet had fallen over a crumbling fossil-laden cliff and been killed as a child:

"What's so fascinating about her anyway? A perfectly ordinary child, no doubt, like yourself?"

"I don't think she ever grew up."

"Rubbish. Everyone does."

"They don't have to," said Maria stiffly. (138)

Maria's stiffness here is key - Maria's cold, stiff exterior is shown in the story to be her defence against strong feeling, particularly her yearning to belong, and the strong feeling being contained in the conversation quoted above is Maria's fear of growing and no longer recognising herself: "I want to be me as I am for ever and ever" (83). She is morbidly aware of the passage of time, as shown in her obsession with the approaching end of her holiday: "And all the while time was leaking away. There were ten days left, then a week, and then the 
days lay ahead singly, five and four and three" (190). There is an obvious doubling between Maria and the girl she fondly, and mournfully, thinks of as dead. Maria's fascination, and secret longing, to halt time and be mourned (which is tied to her own feelings of alienation) is made clear when she visits a church, and is moved by a memorial to a dead child ("Erected by His Grieving Mother"):

Her eyes prickled with not unenjoyable tears - the kind of tears prompted by a sad book. She had sometimes thought of herself dying young. In moments of extreme resentment against her parents she had relished the thought of them weeping over a pathetic (but extremely grand) little tomb in some enormous cemetery, feeling sorry that they had been so cruel to her. (110)

Little wonder, then, that Maria seems so invested in Harriet's death, or rather in the idea that Harriet never grew up. Maria is haunted not just by a girl in the past (a girl with fair hair and a headband, a Victorian drawing-room child reminiscent of Tenniel's Alice), but also by the spectre of her future self:

a grown-up Maria (wearing spectacles, for some reason, with a handbag tucked under her arm, and dressed in a tweed suit like Aunt Ruth's) stood before her, smiling quite benevolently, and so real that it seemed almost possible that other people might see her also. (82)

"[T]he thought of her," we are told, "was somehow entirely unwelcome" (83). The fact that Harriet does not die as a little girl, but grows up into "Mrs Harriet Stanton, [...] (a bit stout, with sons)" (215-6), aligns the end of childhood with the end of life in an overt way. In the end, there is little difference, at the distance of one hundred years, whether Harriet had died young or simply grown up - either way, the girl Harriet was is gone forever.

The ultimate effect of being haunted, for Maria, as for James before her, is connection, and a new and healthy perspective on her position in time. Through Harriet, Maria forges a link to the past which leads to a greater sense of presence in her own life. In 
her investigations of her ghost, she meets Martin, the boy from the loud, messy family next door (there is another kind of doubling and mirroring in their names), and learns how to make a mess. Her encounters with Harriet amount almost to a possession, as when Maria uses Harriet's swing set and seems to physically merge with her, shorts turning to pinny and short dark hair turning long and fair:

an upward climb, and then a lovely shivery descent, rushing feet first down to the ground again, and then forward and up only to be snatched back and down again in a breathtaking swoop, skirt and pinny flying, hair everywhere now because her band had come off and blown away across the lawn. (160)

In these episodes of bodily possession, Harriet effectively gifts Maria with physical exuberance, so that eventually, she is able to play with the big messy family next door and become a runner and a shouter: "Maria, in the thick of it, found herself caught up so as to become not just one of them, but barely even herself at all. She was behaving in a most unMaria-like way. She rushed; she screamed; she pushed and giggled" (176). She is able, crucially, through connecting to the past, to make peace with her own future:

[I'll] grow up into somebody else, like Harriet, thought Maria. [...] And into her head came the idea of mysterious and interesting future Marias, larger and older, doing things she could barely picture. They seemed like old friends she had not met yet. (215)

This peace is partly an effect of Lively's depiction of place: the fossils are a literal embodiment of the presence of the past, inscribed as they are upon the landscape. Places, we are told, "go on and on, with things that have happened hidden in them, [...] like you find the fossils if you break the rock" (67). In the same uncanny doubling of character and place that we have seen in The Graveyard Book, this description informs the novel's construction of childhood as a past that haunts the present: "in a funny way we go on being here forever, aged ten or eleven one summer, because we once were" (215). 
A Stitch in Time is perhaps the most straightforward example there is of the post-War children's ghost story, its methods, and its concerns. It portrays a child in a state of alienation, who then finds a connection to the past which anchors the child in the present. It is a project of conscious memory-making which is invested in the child figure. Consider Maria, thinking to herself: "when I'm grown up, I shall come back here and think of myself sitting here now, today" (82), and in doing so demonstrating the impulse behind the genre.

The protagonist in Penelope Farmer's Charlotte Sometimes (1969) shares many traits with Maria: she is isolated, she is displaced, she fails to make an impression on her surroundings. All of these things cause her pain and grief. The book tells the story of Charlotte, who, on her first night of boarding school, finds herself transported into the past, where she takes the place of another girl, Clare, who attended the same school forty years prior. This story is a strange merging of ghost story and time-slip fantasy: Clare and Charlotte, sleeping in the same bed forty years apart, essentially find themselves alternating days in each other's lives, with Clare taking Charlotte's place in her own time. But for all of the time travel, this is a story fixated on haunting. The time-slip elements function primarily to unmoor Charlotte, to cause her to lose her grasp on her own life, to make her ghostly: "She felt as if she was suspended between these times, the past, this present, that future of her own, and belonging to all or none of them" (Charlotte Sometimes 97). And Clare, it turns out, is long-dead.

Charlotte is subject throughout the story to various large and small forms of displacement: her movements into the past (where she is forced to spend every other day living as someone else) lead to substitutions, imitations and confusions that overwhelm her sense of self. A large part of the emotional effect of the book comes from a certain sympathy at the numb despair that overcomes Charlotte when she realises that she has disappeared, has been replaced by someone else, is replacing someone else, and that nobody has noticed. This recalls Maria's painful sense of failing to make a mark on anything: Charlotte and Clare, while they have things in common (they are both starting school, they are both the children 
of dead mothers, they are both older sisters) are by no means identical. And yet, for Charlotte, they are distressingly interchangeable: Clare's sister Emily fails to notice at first that anything is different, and then tells Charlotte, "I don't suppose I ever looked at you properly - or Clare. I mean, I knew you - her - too well, at least I thought I did, perhaps that's why I never thought that you were different" (73). This interchangeability affects Charlotte's own self-perception as well as the perception of those around her. In the middle section of the book when she is in lodging and kept away from the particular boarding-school bed that allows her to return to her own time, she is subsumed: "[s]he was so used to trying to behave like Clare that she could not remember what it was like to behave like Charlotte. She scarcely seemed to know even who Charlotte was" (177).

But even before her adventures in time begin, Charlotte is shown to be struggling for an identity. Having just arrived at boarding school, she is uncomfortably conscious of being the only one without any sort of ornament on her chest of drawers, which "remained bare and personless" (9). The school, as home-away-from-home, is dichotomic: it manages to be domestic (and, over time, secure) without ever becoming a home space. For Charlotte, the school's ambivalent status, its failure to be home, is only exacerbated by its newness and unfamiliarity:

She scarcely felt $[. .$.$] real herself, indeed spent much of her time hunting for her$ name; on lists, games lists, table lists, class lists, cloakroom lists; on everything, everywhere, lockers, pegs, drawers, clothes, shoes, even on her toothbrush and sponge, as if she needed it to prove her own reality. (9)

Switching times and lives with Clare only serves to underscore the acute self-consciousness and self-doubt that are already the prevailing conditions of Charlotte's life.

The boarding school is a particularly apt setting for the unsettling interchangeability that troubles Charlotte's sense of herself. The school as represented here (and schools generally in children's literature) are haunted - if not by ghosts then by their own history, by the generations who have lived in the same space in much the same way. There is a sense of 
the cyclic repetition that characterises childhood as it is shaped at a school, a sense of transmission, transition, and fleeting possession. Your desk and your bed and your chest of drawers are no such thing. They are inherited from those who have gone before and left their mark (like initials scratched onto a table, or the exercise book that Clare leaves wedged into a hollow bedpost), and they are on loan from the future. This characteristic of the boarding school underlines a cultural childhood that is constructed as once and future, and Charlotte Sometimes makes clear the way that this positioning can cause an uneasy tension for the present, individual child. Further, school, as the first step out of the home, is where the end of childhood begins; this is yet another way that the sense of imminent and yet infinitely postponed ending (coded as mortality) manifests itself in the literary depiction of childhood.

Charlotte Sometimes foregrounds mortality, however, by turning children into ghosts. The first and most obvious is Clare, who is revealed at the end of the story to have died in the influenza epidemic of 1918, shortly after she and Charlotte stopped impersonating each other in each other's lives. She is ghostly in formal terms as well: in the narrative, Clare is defined by her absence. Charlotte is the only point-of-view character, and as Clare is unable to share a time and space with her, neither Charlotte nor the reader ever meet her. Our only access to her feelings are through the notes she writes to Charlotte, and in the distressed and distressing call for her younger sister during the séance in Part II: "Emily, Emily, Emily, where are you? There's so much noise, Emily, Emily" (149). There is a quiet sort of horror in Clare's fate - she is solemn and unremarked upon in her own life, and then exiled from her own time and, given the evidence of the séance, tormented by it. She finally returned from her ghost life, only to die and become a ghost. The forty years between Clare's life and Charlotte's serve to numb her loss into something faded and sepia-toned, as an elderly Emily reports to Charlotte in a letter:

Did you know Clare had died? [...] Of course, it was a terrible shock, but more than forty years ago now, a long time. Clare caught flu not long after she returned: had 
it very badly for some reason, and died about four days later. Many died of flu that year, you know. (196)

All children, except many, grow up. It is Charlotte, days and forty years away from literally walking in Clare's shoes, who mourns her as though her heart is breaking: "She was crying and crying for a girl who had died more than forty years before, whom, in any normal world [...] she could not possibly have known; whom she had never even seen, though she had lived as her. She was crying for herself, perhaps, and for Emily" (190).

Charlotte does cry for herself. While there are many good practical reasons to kill Clare off purely in terms of story mechanics (it takes care of the problem raised by the possibility of Clare replacing Charlotte as a twelve-year-old in a time she already exists in as an old lady; it allows others to sleep in the magical time travel bed without exchanging lives), but the important metaphorical effect of putting Charlotte into the life of a child who will die instead of growing is to bring mortality home to her. As has been made clear, Clare is not the only ghost in this ghost story: Charlotte's own position (especially in Clare's time, but increasingly in her own) is tenuous and ghostly: "She had been kind of a ghost herself" (193). She is described repeatedly throughout the book as oddly numb, and her experiences are described in terms of dream and sleep, terms that question their reality and solidity. Charlotte is "dreamy" and "lulled"; she "always seem[s] to be sleepy" (66). Her personality is squashed beneath the pressures of moving through time and living half of two lives with only one of them her own, and "what was an ordinary shyness becomes an abnormal reticence" (Jackson, "Uncanny Hauntings, Canny Children" 171): "often she did not know what had happened, what was going on, and she was afraid of showing it [...]. It seemed safer usually not to speak at all" (41-2).

But Charlotte Sometimes is riddled with death imagery even before ghosts are taken into account. The past that Charlotte haunts in Clare's place is a very particular past. It is 1918, during and just after the end of the First World War. This makes the book a war story as well as a ghost story: as well as metaphorically permeating the book and the construction 
of childhood it contains, death (with its concomitant haunting) is an important organising principle at the level of plot. Clare and Emily's father is away at the front, and the fear of his loss informs both Clare's solemnity and Emily's rash impetuosity; their school-friend, Bunty, loses her father on the front lines during the story. There is the image of their teacher, Miss Wilkin, who had been happily engaged to a soldier on the front, diminished by grief: "Though as neat as ever, she looked bedraggled somehow, a little shrunk, her clothes not quite so tight on her as before. [...] [S]he twisted her ring continuously, but did not look at it" (135). There is also Arthur (the lost brother of Agnes Chisel Brown, daughter of the family Charlotte and Emily billet with at Flintlock Lodge), able to be brave and heroic only in memory. There is doubt, indeed, whether Arthur died heroically at all; Agnes admits to Charlotte that on Arthur's last leave before being killed, he had admitted that he didn't want to return to the front: "he said, Aggie, Aggie, it was so terrible I could not imagine, and he was afraid he might run away if he went back, and they shot people who ran away" (153). Arthur did return to the front, and Agnes cannot quite bring herself to believe the letter from his superior officer that assures his family he died bravely: "I believe, dear, they send such letters anyway. To spare relatives' feelings, so it is said" (154).

Perhaps the most interesting thing about Arthur's story for our purposes is Agnes's compulsion to tell it, and to tell it to Charlotte, her twelve-year-old lodger, in particular: "I don't know why I'm telling you, it's a past story. You don't really want to hear it, do you dear?" Charlotte doesn't know how to reply, and "Miss Agnes went on talking regardless, hesitating at first but quickly growing faster" (153). This recalls Alice, politely waiting for people to stop reciting at her in the Land through the Looking-Glass. Here, Agnes's story has two major functions. For one, it displays the repression of which the ghost is a literal representation. Arthur, in his fear and in his failure to measure up to his own ideals of bravery, is a skeleton in a closet, a secret making itself known and disrupting the linearity of history. But further, and more importantly, it is an in-story demonstration of precisely the rupture, caused by war, which gave rise to the haunted quality of this post-war fiction for children. In this context, Agnes's compulsion to share the secret - to unburden herself of 
memory and to nominate Charlotte as the keeper of it - speaks particularly to the functions of the genre. Charlotte, here, is a repository for memory, recalling the function of toys in the last chapter as a resting-place for (past) childhood; a container in which memory is kept, and occasionally revisited.

Charlotte's entire role in the story (rather than just as the ambivalent audience to Miss Agnes's secret) is disquietingly doll-like. Her assumption of Clare's role in Clare's life amounts to a sort of possession:

Clare had always been a kind of skin around her, Charlotte thought, containing what she did and said and was; but the skin had thickened imperceptibly the longer she stayed in the past [...] pressing that part of her which still thought of itself as Charlotte tighter and smaller, until it lay deep down in her, like a small stone inside a large plum. (123-4)

On her return to her own life, Charlotte is responsible, like the dolls of the last chapter, for keeping the memory of Clare, child-that-was. Charlotte is also doll-like in her almost startling passivity as a character: faced with the impossible and uncanny, she is frozen into stillness, and "turn[s] her mind wildly away" (18). While there is a great deal of psychological complexity and sympathy in Farmer's depiction of Charlotte, she is hardly a traditional protagonist. This is acknowledged in the narrative when Charlotte realises that she does not measure up to storybook heroes: "She thought herself stupid now for not realising immediately, as children did in books" (26). Like a doll, Charlotte does not move, but is moved by the events and action around her; like a doll, she is given memory in order to keep it.

The close link of this function to mortality is shown here not only by the ghosts, whose hauntings are the means by which memory is transmitted, but by the death imagery connected to the actual toys in the story. Consider the ivory Spillikins, that "look like little baby bones" because they are bones (94); or the toy cupboard in the dark and oppressive dining room of the Chisel Browns and the toys "of a generation back" it contains. A doll is 
laid to rest "wrapped in tissue paper, which had none of the crispness and whiteness of new paper. It was yellowed, soft as muslin" (93). The imagery is that of burial (coffin and shroud), and the close association of the doll to Charlotte, herself the keeper of a long-lost childhood, is clear. It is unsurprising, then, that Charlotte's souvenirs of the past she lived in and lost are toys - the marbles she places upon her chest of drawers in a glass of water, and the lead soldiers that flank them. The marbles had previously been explicitly linked to childhood memory. Charlotte, examining one of them, remarks how different one of them looks when taken out of the water:

It was like the difference, for instance, between Arthur's image of war and his experience of it. It was like other times, her own and Miss Agnes's proper childhood times, that seemed so near to her memory and yet so far away. It was like everything that made you ache because in one sense it was so close and in another unobtainable. (155)

This thesis argues that childhood in children's literature is eulogised; it is universally characterised as past even in its present tense, and mourned for even as it unfolds. Charlotte, as in the quote above, models this precise sense of eulogy. Having learned that she can return to her own time, she indulges, again preemptively, in nostalgia: "[f]or the rest of the day, despite pleasure and excitement, Charlotte was overwhelmed by a huge and melancholy nostalgia [...] she was trying to fix it all in her mind - how the past looked and sounded" (178-9). This continues after her return, when the past has become a memory, rather than just the anticipation of one: "all that was left to her of the past was the nostalgia she felt at unexpected moments" (184). Childhood, like Charlotte, is both haunted and haunting.

But the ending of Charlotte Sometimes, as all of these stories do, insists on the power and value of transmission, the necessity of mourning, and the benefits of a meaningful and personal connection with history. The marbles and soldiers, placed on her dresser, mark her out as an individual, no longer adrift, but anchored by her experiences: "no longer now was her chest-of-drawers the only one without an ornament. It looked individual. It belonged to 
someone" (198). Becoming someone, in this story, is intimately associated with loss and with memory:

she had begun to realise that she could never entirely escape from being Clare. The memory of it, if nothing else, was rooted in her mind. What had happened to her would go on mattering, just as what had happened in the war itself would go on mattering, for ever. (198)

The ghost in these stories is a means of transmitting memory, of making history real and, paradoxically, vital. The personal contact with history that the child characters share in these ghost stories - "the discovery or rediscovery of the past" as Humphrey Carpenter terms it (Secret Gardens 217) - works as a part of the conscious memory-making, and the mourning for what exists only in memory, that is both the subject and the object of the genre. 


\title{
Chapter Five
}

\section{Fleeting and Eternal: Time-Slip Fantasy}

\author{
it is but a child of air \\ That lingers in the garden there. \\ Robert Louis Stevenson, "To Any Reader"
}

The generative gap caused by the adult-child relation at the centre of children's literature is above all else a gap in time. As has been said in previous chapters, a reckoning with the workings of time is unavoidable when writing to, of, and for children: adults must always contemplate childhood retrospectively, and writing across the gap is inevitably a work of memory as well as of imagination. Time-slip fantasy, which explicitly builds setting and space out of memory, and whose primary business is to portray a direct encounter with the past in the lives of its child characters, is particularly pertinent in a discussion of the way that the gap at the heart of the genre works to produce and inflect writing for children. Victor Watson, in The Possibilities of Children's Literature, argues that children's fiction as a whole works towards "the imaginative creation of a cultural space" - "an arena," in other words, "in which children and adults can engage in various kinds of shared and dynamic discourse" (11). The cultural space Watson describes is a direct outcome of the gap in time between adult and child (there is nowhere to build without it): time-slips make this cultural space manifest.

Time-slip fantasies are very similar to the ghost stories of the previous chapter in their insistent focus on the presence of the past, and the way that the past acts as a force in the present. Both ghost stories and time-slips flourished in British fantasy from the 1950s to the 1970s, during children's literature's so-called Second Golden Age, and, like the fantasies of the first Golden Age, they are a direct response to what was largely felt at the time to be social and cultural rupture. The chapter on Victorian fantasy outlined the cultural context, 
and troubled relation to the past of the late nineteenth century. Richard Terdiman calls this troubled relation a "memory crisis":

the uncertainty of relation with the past became especially intense. In this period people experienced the insecurity of their involvement with the past, the perturbation of the link to their own inheritance, as what I want to term a 'memory crisis': a sense that the past had somehow evaded memory, that recollection had ceased to integrate with consciousness. (Present Past: Modernity and the Memory Crisis 3-4)

In the midst of this memory crisis, a product of the rapid social and physical revolution of the time, literary childhood became a lightning rod for anxieties about the past and its relation to the present. Britain, in the period following World War II, found itself in a similar state of flux, and therefore crisis:

In the late 1940 and early 1950 [...] there was a real threat to the past. The war had destroyed much and postwar reconstruction in Britain did not follow the European pattern. Where the Poles and the Germans showed a reverence for their respective pasts by replacing their razed cities with faithful replicas, Britain set about sweeping away the bombed remains of architectural gems and medieval city centres. In an epidemic of modernity and apparent hatred of the past, loved landmarks and townscapes succumbed to rebuilding mania. (Hall, "House and Garden" 154)

This physical reshaping was matched by a similar reshaping of the social and economic spheres: once again, the generation gap widened between the lives of parents and the lives of their children. It is in this context that both the ghost story and the time-slip fantasy, with their overarching sense that "the present and future are not safe if the past is forgotten or obliterated" (Hall 154), rose to prominence. It is little wonder, by now, that these fictions of the past and its presence appear in the literature of childhood, which is so powerfully emblematic of both. The same impulse goes to the heart of the intimations of 
mortality that are here, as always, so definitive: a contemplation of time seems to entail a contemplation of its ending.

Linda Hall calls time-slip fantasy "fiction with its feet in the present but its head and heart in the past" (154), and it is clear even in the title that the past is a central concern in Joan G. Robinson's When Marnie Was There (1967). "There" emphasises the important of place in the story (place, it will become clear, is central in all time-slip narratives), but the focus is clearly on when Marnie was, as much as on where. In its depiction of the relation of past and present, When Marnie Was There demonstrates just how uncertain and permeable the distinction is between time-slip and ghost story in post-war fiction. Both genres describe the physical dislocation and social isolation of their protagonists; both depict the past as haunting; both, also, make the past vitally present in the lives of their characters in different but closely aligned ways.

Just as Charlotte Sometimes in the last chapter melded ghost story and time-slip, When Marnie Was There is time-slip that shades into ghost story. Like a ghost story, When Marnie Was There aligns literary childhood with the experience of loss; like a ghost story, it elevates this relation to a central theme. Robinson's protagonist, Anna, has much in common with Penelope Farmer's Charlotte. Like Charlotte, Anna is displaced, removed from her usual home into a home space that is older and more invested with memory and history. Like Charlotte, she forges a personal connection with a past child that transforms history into memory. Like Charlotte's, too, Anna's connection with the past is depicted as sorely needed: When Marnie Was There takes up the theme of the unhappy girl alone, the girl stifled, the girl both haunted and haunting.

Anna is, at the outset of the story, described as almost completely detached from everything around her, and indeed from her own thoughts and feelings. She lives with a foster-mother, having lost both her mother and her grandmother, and she is separated from her foster-mother after a bout of bad health, when she moves to Norfolk to recuperate with the Peggs. Feeling abandoned, and under the mistaken impression that she is an unwanted 
burden, fostered only for the money she brings in from the state, it becomes clear that Anna has adopted "thinking about nothing" (9) and "not-even-trying" (10) as a conscious and deliberate effort to make herself ghostly. She describes herself as "outside" the business of living:

things like parties and best friends and going to tea with people were fine for everyone else, because everyone else was 'inside' - inside some sort of invisible magic circle. But Anna herself was outside. And so those things had nothing to do with her. It was as simple as that. (When Marnie was There 10)

Anna is described throughout the book as ghostly, both in appearance and in terms of her stated desire to leave no impression on the world around her. She is characterised as "pale and solemn" (156), and "scrawny and a bit sober-sides as well" (21). Anna's selfdescribed "ordinary face" is designed to ward off the notice and attention of those around her, to render her invisible: "So the 'ordinary' face had worked," we are told, "No-one had even noticed her" (13). Anna is the point-of-view character, and her detachment makes her unreliable: the reader is forced increasingly to question and doubt her judgement. It becomes clear that, despite her near constant protestations to the contrary, Anna minds her isolation dreadfully; it also becomes clear that her "ordinary" face has not worked at all, at least in the way Anna intended. Her pain and unhappiness has been noticed - by her fostermother, by her teacher, by her doctor - and their concern is the reason Anna is sent to Norfolk, and into the care of the homely, old-fashioned Peggs, in the first place.

Norfolk as a setting makes Anna's time-slip possible: it is characterised in the story as a place where older ways of life endure, and where the past is far more intensely present than in Anna's home in the city. Mr and Mrs Pegg still speak in an old-fashioned Norfolk vernacular ("I can't say I ever heared the words afore," Mr Pegg says of the sandpiper and its plaintive cry (29)), and Little Overton is depicted as both naturally, rustically beautiful and as largely disconnected from the upheaval of modernity. Its "great emptiness of marsh and 
water and sky" (25) has not changed for generations; it is a place where a relic like The Marsh House, the focus of the time-slips in the story, might still be found.

And it is The Marsh House that draws Anna into a personal connection with the past, even before she meets Marnie, the girl who once lived there. "As soon as she saw it," we are told, "Anna knew that this was what she had been looking for" (25). The importance of "old" setting (and a desire to protect it from the forces of change) in time-slip fantasies cannot be overstated. The very rapid social and physical revolution that gave rise to the anxious feeling for the past that shaped post-war British fantasy for children makes these stories fundamentally conservative. As Linda Hall writes:

Since a house and its garden seem to provide the ideal focus for exploring a feeling for the past, this readily suggests a desire to preserve; indeed, the major postwar examples of time-slip narratives are essentially conservative, in the best sense of that word, meaning [...] conservationist, both historically and environmentally. Environment and history in fact unite in that sense of place on which the structure of feeling in these stories is so often focused. ("House and Garden" 154)

In When Marnie Was There, this sense of place is focused on The Marsh House, which is presented in the story from the first as a symbol of steadfast continuity:

This house stood alone, and had a quiet, mellow, everlasting look, as if it had been there so long, watching the tide rise and fall, rise and fall again, that it had forgotten the busyness of life going on ashore behind it, and had sunk into a quiet dream. $\left(25^{-6}\right)$

Anna is enamoured of this quiet eternality; the house has the qualities of quiet somnolence, of apartness, of forgetting, that Anna is shown to crave for herself. Paradoxically, though, the house is also the site of memory: the memory of Marnie and Marnie's childhood, which Anna shares in through the mechanism of the time-slip. Later, through the Lindsays (the large, 
rambunctious family that moves into The Marsh House in Anna's present timeline), the house is restored to vivid life.

Here, again, Valerie Krips's conception of children's literature as lieu de mémoire is important. Krips sees the project of communal memory-making as foundational in literature for children, particularly in this post-war period: indeed, the transmission of memory constitutes a large part of the cultural space that is created by the genre as a whole. In timeslip fantasy, this memory-making rises to the level of plot. The present child, Anna, in her interactions with the long-ago child Marnie in the past of Marnie's childhood in The Marsh House - playing, going to a party, telling secrets - comes away with first-hand memories of that long-ago childhood. Anna herself carries these memories into her future, just as the reader carries memories of the book. Plot, thus, mirrors the peculiar temporal reference of the children's book, which is, as Krips writes, "both to the present and past, to memory and the promise of a memory" (The Presence of the Past 25).

When Marnie Was There differentiates itself from ghost stories (which also construct childhood as memory) in its insistent description of Marnie's physicality. She is positively robust in comparison with pale, scrawny Anna: "Yes, the girl was real, her dress was made of a light, silky stuff, and her arm when Anna touched it, was warm and firm" (65). From the first, the relationship between Anna and Marnie is characterised by touch, by physical intimacy. Within minutes of their first meeting, the girls touch each other to test their own and each other's reality; Marnie physically holds Anna back when she tries to stalk off in a huff and pulls Anna down beside her. Later, the girls hold hands and Marnie flings her arms around Anna's waist: "Anna did not remember ever being so close to anyone before" (68). For Anna, "wrapped around in [her] quiet, untouchable state of not-caring" (61), this is the stuff of dreams. It is precisely this laying-on of hands that breaks through Anna's isolated, untouchable state. When Anna meets the Lindsays, their relationship is also established through touch. After a one-sided game of hide-and-keep-away, Anna finds herself surrounded by the five Lindsay children: 
"Got you!" one of them shouted, and her ankle was seized in a strong warm hand. $[\ldots]$

[Andrew] leaned forward to examine the red marks left by his fingers. "It doesn't hurt, does it?" Anna shook her head. (184)

Anna, through her relationship with Marnie, is no longer hurt by closeness. The time-slip (like the hauntings of the last chapter) is both a result of Anna's unnatural state of isolation, and the means for healing it.

Another element separating this story from a more traditional haunting is the fact that Marnie's presence, along with the past's hold on Anna, end only partway into the story: Anna stops moving back in time with fifteen chapters to go. The time-slip, as so much in children's literature, hinges on its own ending. The rest of the book tells of the aftermath; it tells of Anna's mourning of her relationship with Marnie, and of her new relationship with the very much alive-and-present Lindsays. Surrounded by their casual and ready affection, Marnie becomes "no more than a ghost of a memory" (191) - but a memory that Anna has learned how to cherish, even as she mourns it:

even as she wept, a new and delicious sadness was creeping over her. The sadness one feels for something enjoyed and now over, rather than for something lost and never found again. (176)

Anna is "comforted by her own tears" (176), and this comfort - the "delicious sadness" of memory - speaks directly to the centrality of endings in this literature. For all that these stories manifest a feeling for the past and an insistence on the importance and enrichment of memory, time-slips are as much about the future as about the past. The past is present, in these stories, and then it is invariably let go and mourned.

This characteristic ending of the time-slip plot only serves to emphasise again the importance of place and how much is invested in it: The Marsh House, linking as it does land and water, inside and outside, past and future, is the only real constant in the narrative. Anna's entire character development in the book is described as a process of anchoring and 
grounding, both literal and metaphorical. A twist in this story is that Marnie is no random child, but in fact Anna's lost grandmother, and The Marsh House is Anna's ancestral home. The past that Anna discovers and connects with is the personal past of family history: it is no accident that she finds her grounding and belonging in that particular place. Both Marnie, the long-ago child, and The Marsh House of Marnie's childhood are associated with the liminality of water. Marnie has a boat whose anchor is used emblematically to represent her in her absence, and for a long time, Anna mistakes the back of The Marsh House (the side facing the water) for the front. When she is with Marnie, Anna says that she prefers the water side of the house - it is reflective, permeable, and above all, unearthly. Among the Lindsays, however, she learns the pleasures of the side tethered to the land:

For some reason, she had always thought of the front as if it were some quite different place. Now, for the first time, she realised what she always must have known, really; they were two sides of the same house. And this side was, if anything, even more attractive. It had a warm, welcoming look which she had never expected. (171)

In The Marsh House, connected both to her own history and newly anchored to her present and the people who surround her and care for her, Anna is able to move from outside to inside, and to become the kind of person who goes "to tea with people." It is the house itself, with its enduring quality - it "looked as if it had been there forever" (136) - that allows this becoming.

The house as a symbol of constancy and endurance in the face of time is also the major focus of L.M. Boston's Green Knowe series (1954-76):

The house which is both the setting and the subject of Boston's novels seems almost more important that the people who have lived within its walls, if only because it outlasts their individual mortality and so can become the symbol as well as the receptacle of that continuity without which all human effort seems purposeless. (Hall, "House and Garden" 155) 
The Green Knowe series is in many ways a series of love letters to the past - a past that is shared with, transmitted to, participated in, and embodied by the child characters that inhabit the books. And they are love letters that focus on a particular house: the Manor at Hemingford Grey, called Green Knowe in the stories themselves, whose thick stone is set against the ephemerality of the childhoods that pass through it. The Manor was Boston's own home at the time she was writing the series, and the novels are driven by a particularly personal love of place, as well as by nostalgia and nostalgia's peculiar sense of regretful longing, in which the ideal past is set against the present's comparative lack. Against this notion of progress as a form of decline, Boston sets Green Knowe as a bulwark. It is a place where the past is manifest in every (present) day, both ancient and somehow timeless.

The Green Knowe stories demonstrate, characteristically for time-slip fantasy, the impulse to forge connections across time that Peter Hollindale persuasively claims is the motivating force in the genre at this period:

[T] he ubiquitous fictions of time travel [...] are inspired not by love of the past for its own sake, not by interest in its differentness, but much more by the process of transmission and continuity, the subtleties of kinship between dead and living, and the features of hidden resemblance which underlie surface change. (Signs of Childness in Children's Books 67)

This interest in continuity, on the kinship between the living and the dead, can be extrapolated to the entirety of children's literature and to the adult-child relation at its heart. The Green Knowe stories build themselves around this continuity, even as they foreground the movement of time.

The first book in the series, The Children of Green Knowe (1954) elides the time-slip with the ghost story, but even so it illustrates Boston's preoccupation with time as a theme and organising principle. This preoccupation is clear from the first pages, in which we meet Toseland (Tolly), our seven-year-old protagonist, in the peculiar and particular suspension of transit. Sent away from home by a wicked stepmother straight out of a storybook, he sits in a 
train carriage heading for a house he has never visited, and a great-grandmother he has never met. He shares his carriage with two local women, busily knitting, "and whenever the train stopped the click-clack of their needles was loud and clear like two clocks" (The Children of Green Knowe 7). Although this book contains no direct time-travel, it is clear that Tolly's journey to Green Knowe is a journey in time as well as in space: his presence in his great-grandmother's house is a form of direct contact with the past. Tolly, through this great-grandmother, the aptly-named Mrs Oldknow, becomes the recipient and inheritor of old knowledge. He hears the stories of the children who lived and died in the house three hundred years before; he touches their relics (his bedroom is almost a shrine, containing all of their carefully-preserved books and toys and treasures); he shares their space, sometimes directly. At one point, Tolly and the ghost-child Toby sit in the same spot in the inglenook at the same time, "as if [they] were both the same person" (102).

That Green Knowe is full of doublings and reflections is clear from the moment that Tolly steps into the entrance hall with Boggis, the gardener:

As they stepped in, a similar door opened at the far end of the house and another man and boy entered there. Then Toseland saw that it was only themselves in a big mirror. [...] There were three big old mirrors all reflecting each other so that at first Toseland was puzzled to find out what was real, and which door one could go through straight, the way one wanted to, not sideways somewhere else. He almost wondered which was really himself. (13)

Indeed, this doubling goes further. Tolly is shown to be almost a literal embodiment of his family history, having inherited his face and body as well as his name: "So you've come back!" Mrs Oldknow tells him. "I wondered whose face it would be of all the faces I knew [...]. They always come back. You are like another Toseland, your grandfather. What a good thing you have the right name, because I should always be calling you Tolly anyway" (Children 16). Mrs Oldknow is herself an iteration, this time of the grandmother who lost three 
grandchildren and a daughter to the Great Plague within a few hours on a day three hundred years in the past.

Tolly's coming to the Green Knowe for the first time is framed much more as a return than an arrival. He seems not so much to discover the house and its secrets as rediscover them: "Tolly felt as if he had lived here always instead of just one day" (35). The book insists upon Tolly's easy and instinctual (re)connection with the house and the family history it contains. When, for example, he compares the house surrounded by floodwaters to Noah's Ark, Mrs Oldknow claims it evidence of belonging:

"Yes, all the children used to call it the Ark. Your grandfather did, and he learnt it from his father, who learnt it from his, and so on right away back. But you called it that by yourself." (22)

It is important to note here Boston's emphasis on domestic, family memory rather than on matters of historical import. The past called into being by the Green Knowe books (and time-slip fantasies in general) is centred on individual and family legacy and inheritance. Raphael Samuel calls this construction of the past "living history" or "history from below": it is focused on "the spirit of place rather than that of the common law or the institutions of representative government" (Theatres of Memory I 158). This emphasis on inheritance, and on the spirit of place, is characteristic of Boston. She works hard in Children of Green Knowe to make the manor house timeless (another word for immortal), and an important part of this construction is the depiction of repetition and renewal that extends to the family themselves, as well as to the setting that shapes their lives and their sense of themselves.

This setting is dominated by Green Knowe itself, and by the river that acts as the major symbolic foil to the house's stony solidity: "The river is a very lively inhabitant here, always to be reckoned with ... " (Children 93). Rivers tend to play an important role in timeslip stories, which characteristically use setting symbolically and metaphorically to relate space to time and its passing: it represents at the same time time's constancy (as a stable 
feature of the landscape) and time's constant movement (in the ineluctable movement of water). This use of rivers recalls the thought of Greek philosopher Heraclitus, who famously used the river as an image of the complex relationship of humans to time. His famous aphorism is quoted in Daniel Graham's article on Heraclitus in The Stanford Encyclopedia of Philosophy: "on those stepping into rivers staying the same other and other waters flow" (n.p.). Here, Heraclitus is not only - or not simply - saying that everything changes. He is describing the interconnection between constant change and "staying the same" (whether what stays the same is the river itself or those that step into it is purposely ambiguous) that characterises how we experience time and change. The change that buffets us paradoxically bolsters a sense of self that remains stable, even as we ourselves change in ways that are often only visible in hindsight. Stability, in this formulation (whether of the river, or of the individual) depends on the continual flux contained within it. "Some things stay the same only by changing," Graham says of Heraclitus' thought. "Constancy and change are not opposed but inextricably connected" (The Stanford Encyclopedia of Philosophy n.p.).

Constancy (and constancy in the face of change) are at the heart of Boston's depictions of Green Knowe: little wonder, then, that she makes the manor house a literal island, standing still and solid in the shifting river. "[T]he island on which Green Knowe stood," she writes, " was slightly humped, just enough to keep it clear of the floods, and that was how there came to be such an old house on it" (The River at Green Knowe 7). It is no accident that Tolly first comes to the house during a flood, and is forced to approach the house, unconventionally, by rowboat; it is no accident, too, that the house is more than once referred to as an ark (22). The house (in a way that would be mirrored in The Marsh House in When Marnie Was There) occupies a liminal space, one in which boundaries - between land and water, between garden and world, between past and present, and indeed, between life and death (one of the ghost children tells Tolly that their mother in heaven, "doesn't mind us coming here" (100)) - are easily crossed. Green Knowe makes space for magical thinking. The haunting in this story is rarely frightening to Tolly, young as he is, because Green Knowe is not contested space, but happily shared. 
In the true time-slip of The Chimneys of Green Knowe (1958), the second book in the series, there is a shift in emphasis. Where Children focused on constancy as a weapon against fleetingness, on the elements of the past that survive into the present and provide identity, community, and connection, Chimneys is much more insistent on change, and on time's inescapable forward march. Two years after the close of Children of Green Knowe, Tolly returns from his term away at school to find the house different, empty of its usual ghosts: "He was in a hurry to go over the house and garden to see that everything was the same, but as soon as he crossed the threshold he knew that it wasn't" (The Chimneys of Green Knowe 9). Part of this shift is framed as purely temporal: "Of course the place looked different. He had only seen it in flood, in ice and in snow. This time the wide and wandering garden was silky with daffodils. The cherry trees were coming into blossom ..." (9). The very dynamism of spring is itself in direct contrast to the peculiar stasis of the last book, where the house was surrounded by water and snow, a stalwart standing fast. But another, more crucial part of the shift is the sudden foregrounding of the ways Green Knowe has changed rather than the ways it has stayed the same. In Children of Green Knowe, Boston emphasised the age and solidity of the house, lending it an air of permanence and immovability. This book tells of the revolutions the house has undergone: it has been built onto, altered, redecorated, and partially destroyed by fire. In the present-day of the story, Mrs Oldknow reveals that the roof of the house is falling in, endangering Tolly's inheritance: "you know the house will be yours, and I hope your children's, too. It mustn't fall down" (Chimneys 12). Concern for the future explicitly endangers Green Knowe's relationship to the past: Mrs Oldknow is forced to exhibit the painting of Alexander, Toby, and Linnet that connected their ghosts to the house; she may indeed have to sell it.

It is Tolly's role as detective - his searching for traces of the long-lost family jewels that may save the painting and his home - that leads to the time-slip in this story, in which he moves backward to the Green Knowe of the 1790s, to explore the titular chimneys. There his story intersects with the story of Susan, an Oldknow isolated and trapped by her 
blindness, and Jacob, a slave-boy isolated by his race and status among many in the household as less than human.

Maria Nikolajeva, in her study of time in children's literature, From Mythic to Linear, treats "all children's fiction as essentially 'mythic' or at least nonmimetic," and conceives of literature "as a symbolic depiction of a maturation process [...] rather than a strictly mimetic reflection of a concrete 'reality'" (1). Her argument (a very convincing one) is that childhood is often constructed in children's literature as a "cyclical, mythic state" (5) which is reflected in the treatment of narrative time. This circular, or mythic time (in Greek kairos), is contrasted with and dependent upon chronos, time that is conceived of as linear and measurable. It is precisely the interplay of kairos and chronos, circular and linear time, which gives time-slip fantasies, and the childhoods they contain, their dual qualities of endlessness and fleetingness.

Endlessness and fleetingness are both represented in Tolly's forays into the past in Chimneys. Tolly walks through the garden of Susan and Jacob's time, for example, in which "[e]verything seemed fixed in a trance of eternal sameness" (120). The link between this timeless trance and the timelessness of death is made explicit in the airless tunnel through which Tolly moves into the past (directly under the yews in the garden which traditionally symbolise the loss of the earthly and the hope of the eternal): "He had quite lost his sense of time. Down there where there was neither sunrise nor sunset he might have lost days, or, like Rip Van Winkle, a hundred years" (120). "It's like a grave," Boggis tells Tolly later. "Smells like it too" (157).

But the seeming suspension of time in Tolly's time-slips is contrasted with the chronos of his present. Unlike the previous novel, here in Chimneys, the reader is never allowed to forget that Tolly must eventually go back to school. This sense of time as limited is a corollary of the (temporary) displacement that is characteristic of the protagonists in timeslip fantasy, who are always somewhere other than home, but only for a while. It is also a manifestation of the anxiety at the heart of time fantasy that time will eventually run out. 
The latter chapters of the Chimneys are increasingly filled with clear time-stamps ("[t]he holidays were rushing to a close," we are told, and later, "the day after tomorrow was the end"(155)), marking a literal countdown to Tolly's departure:

And now it was nearly the end of the very last day. Tolly went into the garden. Almost no time left, he thought. Four hours, three hours, two hours, one hour even in the last minute something might happen. Why do people only invent things that go faster and faster, instead of finding some way to keep it at now? (173)

This wish to keep time at now (and the futility of the wish) is a direct articulation of the impulse that drives the time-slip as a genre. Boston puts the tension between now and not-now at the centre of Green Knowe and its particular brand of magic:

Green Knowe was full of mysteries [...] and had no intention of shutting out the un-understandable. Of course, it was largely Time. Surely Now and Not-now is the most teasing of all the mysteries, and if you let in a nine-hundred year dose of time, you in almost everything. (An Enemy at Green Knowe 15)

Boston is careful, as always, to emphasise history and continuity; to find comfort and meaning in patterns that repeat and things that abide.

Green Knowe abides. It functions in the series as a literal lieu de mémoire: everywhere inside it there is evidence of an intention to remember. In a series that revolves around legacy (filtered through water and stone, desire, story and memory), it is fitting that the ending should concern itself with beginnings. The Stones of Green Knowe (1976) goes back in time to the Norman England of the 110os and tells the story of Roger d'Aulneaux, "the first boy that ever lived in the manor" (100), during the drawn out process of building the house: "For almost a year already Roger had watched the thick stone walls of the new house going up" (Stones 1). 
It is difficult to imagine Green Knowe, which until this point in the series has been a symbol of ancient endurance and solidity, as anything approaching new-fangled, but over and over in Stones of Green Knowe, the newness and strangeness of the house is emphasised:

The base of the hearth had been built, not in the middle of the room with no vent for smoke except the hole in the roof as was usual, but in the centre of the main long wall. This was a revolutionary idea. Round the campfire at night the older men strongly disapproved. How could you sit round a fire if there was only one side to it? (14)

The new hall, for Roger and his family, is also a "new way of living" (28): a lifestyle of unprecedented space and privacy compared to the traditional Saxon hall which was their previous residence, with its "smell of woodsmoke and food, and people, and wet dogs, and straw and stable" (2). This space and privacy is also disapproved of ("What do they want an upstairs for, instead of staying among their own people as is right and comforting for both?" (14)), but it is, for Roger, a source of satisfaction and delight: "Roger was proud that his father was so ambitious and adventurous" (15). Here, rather than carrying the weight of years as it does in the previous Green Knowe books, the house is haunted by its future: "the half-finished building under snow and seen through falling snow looked like the ghost of a dream" (26), we are told, "less than half finished as the house was, the future was already there" (14).

This sense of adventurous advancement does not preclude the use of ancient safeguards to bless and keep the house. The master mason uses a piece of stone taken from a church with a Saxon cross on it to set into the wall ("stone takes something from what it's used for," we are told (5); "Stone remembers" (25)), and the laying of the hearthstone is a matter of superstitious and longstanding magic as well as craftsmanship:

The hearth from all time was the centre and heart of the family. Under it would be placed a piece of silver, a piece of iron, and in a cavity a live toad. The silver was for 
wealth, the toad (because it was believed to live for hundreds of years) for permanence, and the iron to keep away the Little People, a smaller race of men who lived here before the Romans drove them out." (15)

Stones, like all of the Green Knowe stories, is a love letter to old things. For all that the stone manor house is new and fresh and Roger's childhood plays out eight hundred years before Tolly's first adventure, Stones retains the sense, so important in the Green Knowe stories, of the age of his island. As Catherine Butler writes, "[m]ost British writers who deal in fantasy have sooner or later to face the fact that they are, in Patrick Wright's phrase, 'Living in an Old Country"' (Four Fantasists 43). This is a country where a boy can, even as far back as the 1100s, unearth a pair of frighteningly ancient stones, rough-hewn into miniature thrones, "dating back to the creation of the world" (41-2), and where those stones can grant Roger's wish to see both the future and the past of his beloved home.

For all that the uncanniness and great age of the stone chairs frighten Roger ("they had no business to be there, they made no sense. They filled him with misgiving" (Stones 34)), it is precisely in the weight of time that he finds comfort. "The nightingale's song," Roger tells himself, "was as old as the coming of the summer after the winter ${ }^{25}$. [...] He did not need to fear things for being old. It was rather a reason for loving them that they had been there so comfortingly long, like hills" (35). The time-slip, even into the distant past, underscores the enduring nature of Green Knowe, in its comforting longevity.

This kind of consolation is the ultimate aim of these books, just as the way that Green Knowe stands fast on its island amid the currents of time is perhaps the most important

\footnotetext{
25 This is a direct reference to John Keats's "Ode to a Nightingale," a meditation on death, and on transcending death through song:

Thou wast not born for death, immortal Bird!

No hungry generations tread thee down;

The voice I hear this passing night was heard

In ancient days by emperor and clown (lines 60-4)

Boston's use of the Ode here is an intradiegetic mirror of the doubled temporal reference that Valerie Krips sees as characterizing children's literature as a whole: even as it comforts Roger to think of the ancient and enduring in relation to his own fleeting present as a small boy, he is also, in relation to the reader, hearing the Nightingale's voice in ancient days. This is, as Krips writes, both a memory, and the promise of one (The Presence of the Past 25).
} 
thing about the place. Indeed, it is a wish for this consolation that leads to Roger's movements through time. Roger is desperately in love with his "particular place," and desperate for it to last forever: his wish to move along the lifetime of the house to see what will happen to it reflects the love of a particular place that animates the series as a whole. "I would like to see it [...] a long time ahead," Roger tells us, "just to be sure, and to see who lives there then" (43). And comfort he obtains: his first slip into the future (into the Green Knowe of Toby, Alexander and Linnet, the ghosts of Children) finds the manor reassuringly solid, for all that the landscape, in which "the fields seemed immeasurably wider [...] and the herds of cattle were sleeker and fatter" (43) is not quite the one he knows. As is usual for Green Knowe, where the past finds itself in the present and vice versa, Roger is recognised as belonging, Linnet saying: "Can't you see he's one of the others? I knew at once" (50). Susan recognises him in the Green Knowe of 1800, and Roger himself recognises Tolly, when Tolly uses the chairs to visit Roger's time: "You're Tolly of course - I'm Roger" (100).

This paradoxical manipulation of memory extends outside the narrative: Roger's meetings with Tolly, with Susan and Jacob, with Toby, Alexander and Linnet, owe almost their entire effect to the reader's recognising them from previous books in the series. There are numerous calls on the reader's memory of the previous Green Knowe adventures here, not least the towering and enclosing beech "tent" under which Tolly played with his ghosts; here it is where all of the Green Knowe children interact in one scene, and where there is the most moving recognition of all:

The curtain was parted yet again, and this time a tall slim girl came in. She was the same age as Toby and just as beautiful, with long shining hair. She hesitated just inside the circle, like someone who is lonely.

[...] Tolly laughed and ran across to her.

"I know you,' he said, taking her hand. 'I'd know you anywhere, any time. You're my grandmother." (Stones 123) 
Again, the picture of the tall girl with the shining hair owes its entire emotional effect to the image of old Mrs Oldknow, current keeper of Green Knowe's memory, and "the old lady, who was quite aware that people do not live forever" (An Enemy at Green Knowe 52).

These repetitions and doublings are only some of the ways that this type of fantasy manipulates time around the child protagonist to reflect both childhood's paradoxically endless fleetingness, and its timeless present. The manor house itself is emblematic of the ever-changing endlessness of childhood, the time-slips around the house only serving to underline its great endurance. Roger encounters the future, just as the reader encounters the past, so Toby, Linnet and the rest are ghosts of things that are both long over and yet to come. They are "the others," safeguarding Green Knowe's history and by doing so, safeguarding its future.

A genre that makes time its theme cannot help but acknowledge loss, however. The large movements of time in The Stones of Green Knowe (the way that time happens to Roger in large and undeniable ways) serve to underline time's inevitable working - and calling attention to the workings of time implies an ending. For a book so focused on the consolation of history and tradition, Stones is very much troubled by the spectre of impermanence. Roger finds the end of each slip painful, for all of the connection and kinship he finds within them: "It's always too short," he tells us, calling for a vanished Toby:

There was no answer. Five hundred and forty years is a long way for voices to travel. [...] Here was Toby, the perfect companion, but to be with him was as difficult as holding water in your two hands. (71)

This anxiety also attaches to the house. When Roger visits Susan in the Chimneys era, he fears that his beloved house has been knocked down: "Roger cried out in grief. The house had gone! Gone altogether, and instead of it there was a square red building much bigger, with many chimneys" (83). Susan, blind and seeing the more clearly for it, reassures him that it has simply been built around: "it's not gone, it's only hiding. I wish I could see it, but I know the feel of it. It's there inside" (89). Roger's feeling for his house and land is deeply 
affected by his knowledge of the future. Walking in the forest that bounds his manor house in his own time, Roger's perception is tinged by future absence:

There was so strong a feeling of isolation, of silence, of secrecy and supernatural power (for trees are alive-they have a still, rooted, powerful life), such a sense of having been there since the beginning, that Roger was cut to the heart by his knowledge that in the future it would disappear. It was in its essence everlasting. And yet this would vanish and his father's house, robbed of its tremendous neighbour, would stand. (102)

Perhaps the most striking and resonant shadow of an ending in this book is the fact that the magic stones themselves, standing there since time immemorial and the means by which the history of Green Knowe knows itself through the children who love it, are shown to be impermanent. The book ends in Tolly's present, with the stones being violently uprooted from their ageless spot on the hillside (they are pulled out "like pulling a tooth" (131)). In a terrible kind of paradox, the stones are taken away in the name of their survival and preservation, to find a place in a museum (whose art, as Catherine Butler has written, "is that of the embalmer" (Four Fantasists 51)). Roger agrees: "They were in their own place," he tells us, "out of it they will be dead" (132). The removal of the stones cuts Tolly off from history in that they prevent his ability to move into the past ("I shall never be able to come to you again," he tells Roger (132)): this is an explicit comment (one we have already seen in Rumer Godden's The Doll's House) on the cost of sealing the past away in order to preserve it.

In the fate of the stones there is a note of concern for Green Knowe itself, especially given that the book works to equate the stones with the house: "the stone that [Roger] was sitting on," we are told, "was the same kind of stone as the manor house walls" (Stones 41). Their fates are intertwined, at least in Roger's head: "He passionately wanted the new house to be there forever, as permanent where it stood as these stones on their hill" (43). But the stones are not permanent, and neither is Green Knowe. At the last, Roger must acknowledge 
the change. The stones, the manor house, the childhood it contains and preserves and represents, all have inevitable ends. The book closes on Roger letting go of the idea of 'ever' to embrace the idea that idea of 'once:' "I can see you again," he tells Tolly, "because in my time the Stones are still there" (133 italics in original).

The illustration on the last page of the Harcourt Young Classics edition of The Stones of Green Knowe is an image of the last line of the story: "the Stones were standing in their place, throwing long shadows before them" (133). This brings a lot of the metaphoric threads in the Green Knowe novels together: the stones are both present and a memory of something gone; their shadows stretch before them into a future from which they will disappear, but not yet. The shadows are shaped like humans; the stones themselves evoke both throne and gravestone. This is a natural conclusion, and an inevitable one in any story that reckons with childhood and its relation to time.

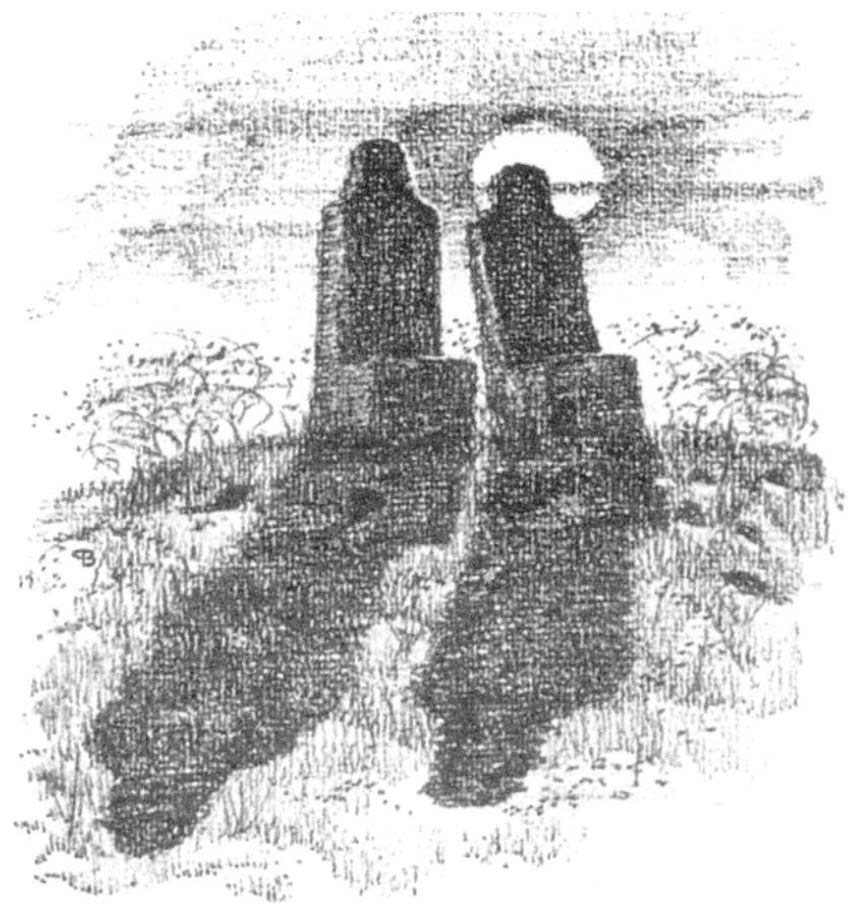

Figure 1. The Stones of Green Knowe, from Lucy Boston's The Stones of Green Knowe (Harcourt Young Classics Edition, 2005, p133. (CDiana Boston. Used with permission. 
Lucy Boston's autobiographical writing makes clear the sense of (impending, inevitable) loss that looms over her loving depiction of Green Knowe. She lived in The Manor House at Hemingford Grey from 1939 to her death in 1990, a time when the lands and fields surrounding the house were increasingly being swallowed by rapid and accelerating post-war development. Peter Hollindale, in "Lucy Boston's Centenary" writes that Boston "was forced into vigorous defensive measures and a continuing sense of embattlement" (144). He quotes directly from her memoirs:

To those for whom what I am preserving is of no value, my embittered defence of it can only seem selfish and anti-social. It was dejecting to find myself . . . forced into the position of public enemy number one in the village, again a position from which there is no escape since as encroachment from every side continues I must always be the animal méchant qui se defend. (Cited in Hollindale, "Lucy Boston's Centenary" 144)

Philippa Pearce, writing Tom's Midnight Garden, published in 1958, was motivated by much the same sense of impending loss. Her father decided to sell her childhood home, Mill House, after retiring, and she wanted to memorialise the walled garden that she, her father and grandfather had all once enjoyed as children: "Suddenly my childhood was chopped off from me ... I began thinking of writing stories based on the house and the garden and this feeling of things slipping away. It's a terrible feeling" (cited in Shirasu 79). "In Boston and Pearce's treatments [of the past] particularly," Catherine Butler writes, "the past becomes the touchstone by which the present may be validated or against which it is found wanting. It is also presented as the taproot that permits present-day growth, the cutting of which threatens to leave the modern world sterile and spiritually dead" ("Children's Literature: Ideologies of Past and Present" 262). It is no accident, then, that the first sentences of Pearce's novel describe a grief-filled goodbye: 
If, standing alone on the back doorstep, Tom allowed himself to weep tears, they were tears of anger. He looked his goodbye at the garden and raged that he had to leave it - leave it and Peter. (Tom's Midnight Garden 7)

A number of themes central to Tom's Midnight Garden are made clear in this first sentence, the importance in this story of tears and a garden, not least. Tom is isolated (he is "standing alone"); he is (about to be) dislocated; he is at the mercy of larger powers, forced into a leave-taking he does not want, chafes against, and can do nothing to prevent. Much like the time-slips already considered, the linking of literary childhood to endings and leavings and loss, and the ways in which it describes both a fleeting present and a long-gone past are elevated to central themes in this book. Like other time-slips, Tom's Midnight Garden overtly manipulates and disrupts the working of time in ways that emphasise childhood's fleeting endlessness.

Tom Long (whose name cleverly suggests longtemps (Carpenter, Secret Gardens 219), underscoring the primacy of time in the narrative, as well as Tom's longing) is forced by his brother Peter's case of measles into a quarantine which exiles him from his home and family. Chapter One is called "Exile," emphasising the enforced and unwilling nature of Tom's removal. He has to spend the summer holiday in the small, poky, and gardenless flat of his Aunt Gwen and Uncle Alan. His relationship with his aunt and uncle is marked, on Tom's part, by outright hostility - a hostility that is reciprocated by his uncle, and both regretted and made light of, however well-meaningly, by his overly doting aunt. The same quarantine means that Tom is not allowed to mix with other people, and his holiday looks grim indeed, with Tom "longing for someone to play with and for somewhere to play" (Tom's Midnight Garden 214).

At night, perhaps in response to Tom's lonely, bored, and sleepless desperation, time bends around Tom: the grandfather clock in the downstairs hallway strikes thirteen, allowing Tom to slip through time and move into the past. The subdivided flats that surround the house disappear, as does the paved courtyard out the back and the new houses beyond the 
fence. It becomes what it had been many years earlier - a stately Victorian home with the same grandfather clock in the hallway and a grand garden for Tom to roam in. Perhaps most importantly, he finds a playmate - Hatty, an orphaned Victorian girl, as lonely and exiled in her time as Tom is in his. Hatty is, further, a lonely and exiled old woman in Tom's present. The final revelation of the story is that Old Mrs Bartholomew, the crabby landlady of the house, is Hatty. She has outlived both her family and, in many ways, her place in the world: she lives in a small attic flat and dreams of the garden of her childhood and the ghostly boy she encountered there.

These images - of a playground outside of time (like Barrie's Neverland); of a space both natural and protected as ideal playground (like Burnett's Secret Garden) - are so important in children's literature as to be foundational. The Garden where Tom and Hatty meet and play recalls the long tradition of Arcadian writing in the first Golden Age of children's literature - what Humphrey Carpenter calls "the Victorian and Edwardian children's writers' fondness for the symbol of a garden or Enchanted Place, in which all shall be well once more" (Secret Gardens 9). And the walled garden is perhaps the perfect image of idealised childhood, as a garden combines natural beauty and careful cultivation. It is a controlled place, one in which growth is either encouraged or weeded out, according to the wishes of the gardener. It is easy to see also, why a garden might be seen as a perfect setting for childhood as well as a representation of it: enclosed by hedges, walls and gates, the garden is protected, domestic space, outside the house, but still of the house. The garden Tom finds outside the back door has Edenic overtones from the first: to a small boy too-long cooped up in a flat, it is certainly an answer to prayer. It is both beautiful and, seemingly, vast, containing

a great lawn where flowerbeds bloomed; a towering fir tree, and thick, beetlebrowed yews that humped their shapes down two sides of the lawn; on the third side, $[. .$.$] a greenhouse almost the size of a real house; from each corner of the$ 
lawn, a path that twisted away to some other depths of garden, with other trees. (Tom's Midnight Garden 24)

But this garden is no eternal Eden, and Tom and Hatty both, in different ways, refuse to conform to the 'ideal' childhood it represents: Pearce raises the ghost of Eden only to dispel it almost immediately. Tom, for example, notices the careful boundaries of the garden only in terms of their possible breaching:

On the four sides of the garden, Tom had already observed that three were walled: one by the back of the house itself, another by a very high south wall, built of clunch blocks and bricks; and another by a lower wall that might well prove climbable. A hedge, however, is almost always more easily passed than any wall; and Tom had no sooner got into his garden than he was curious to see outside it. $(42)$

Before Tom came to it, Hatty had already made herself a way out by tunnelling through the hedge. For all that both Tom and Hatty wish at various times to stay and play forever, neither shows much inclination to stay within bounds. This is childhood depicted, in Michael Chabon's terms, as "an adventure, a strange zone of liberty, walled, perhaps, but with plenty of holes for snakes to get in" ("Dust \& Daemons" n.p.).

The depiction of time is central to the garden, and to the book as a whole: in the background of all the scenes, both those in Tom's present with his uncle and aunt, and in the garden with Hatty, Tom can hear "the only sound that [goes] on: the tick, and then tick, and then tick, of a grandfather clock" (11). It is made clear that the garden for all its wonder, is no timeless wonderland. On the contrary, time happens in the garden in large and noticeable ways, because time inside the garden at thirteen o'clock does not conform to the days and weeks of normal time: Hyacinths bloom and die, seasons shift constantly, Hatty grows up and inevitably away from Tom. This is a garden with a sundial in it: an awareness of the passage of time is always at the surface of the happenings there. 
It should be said, however, that the book's manipulations of time do not begin when the grandfather clock in the downstairs hallway strikes thirteen. That outside-of-time occurrence is the culmination of a number of impossibly long hours in the dead of night in the Kitsons' flat, hours which seem to refuse to end:

The striking of the grandfather clock became a familiar sound to Tom, especially in the silence of those nights when everyone else was asleep. He did not sleep. He would go to bed at the usual time, and then lie awake or half-awake for hour after hour. (14)

At the point where thirteen strikes to save Tom from his desperate boredom ("It seemed to him that his longing to be free swelled up in him and in the room, until it should surely be large enough to burst the walls and set him free indeed" (18)), the interminable minutes suddenly shift into fast-forward, and work against him. Tom argues with himself about whether the extra, impossible hour that thirteen o'clock represents allows him to honourably disobey his uncle and get out of bed, and "[t]he house, which appeared to have been following the argument, sigh[s] impatiently" (21); as he goes to check the face of the grandfather clock, the house whispers "Hurry! hurry! [...] The hour is passing ... passing ..." (23). This kind of time dilation, where the objective passing of hours and minutes and days is set against their length in lived experience, is a direct precursor of the larger suspension to come, the suspension of the impossible - and impossibly dilated - time inside the garden, where the thirteenth hour will allow Tom hours of play while the clock in the kitchen of the Kitsons' flat, which was ugly but "always kept perfect time," stays still at "only a few minutes past midnight" (46).

This eternal moment - the dilated and suspended moment in which the time-slip is contained - is a common mechanism in this kind of fantasy. It is a particularly apt mechanism in a genre which insists on and foregrounds time's inevitable movement: the eternal moment that paradoxically cannot last is part of the tangle of longing and loss at the heart of time-slip fantasy, and of this story. Having stepped out of time once, Tom longs to return: "'I could stay in the garden forever,' Tom told the kitchen clock, and laughed for joy; 
then shivered a little, because forever sounded long and lonely" (174). And forever does sound long and lonely - death is the only state humans are capable of reaching in which they are outside of time and no longer subject to it. The suspended moment that allows even the contemplation of forever carries the spectre of mortality in it, too.

The sense of "time-out" engendered by the endless, suspended moment can be linked to what Roland Barthes "refers to variously as 'mythic time' and dilatory space" (Rudd, "Digging Up the Family Plot" 88) that is created through the act of reading. Barthes is speaking of the mechanism whereby the real-time of reading - the minutes spent turning the pages of a book - is often overtaken in the reader's mind by narrative time; by the passage of days and weeks inside the story. Pearce uses this idea to great effect in Tom's Midnight Garden, where the relativity of time (how time is felt, by Tom in particular) is foregrounded. Tom's sense of the passage of time is shared by the reader, and much of the emotional force in the book comes from the ways in which his experience of time is manipulated and described.

Nikolajeva's conceptions of kairos (circular, mythic time) and chronos (linear time) are very pertinent to Tom's Midnight Garden. When Tom leaves the endless night-time hours of the Kitsons' flat and comes upon the midnight garden, and the playmate who will share it with him, he enters kairos, signalled by the constant use of the iterative frequency to signal events that take place repeatedly and regularly: "Every night now Tom slipped down to the garden" (Tom's Midnight Garden 48), we are told; "he saw the garden at many times of its day, and at different seasons" (49); Hatty sees him "often - and often - and often" (73). There is a sense of comfortable and frequent repetition: "When they were tired [...] Hatty would lead the way to the summer house. [...] There they used to sit, looking over the oblong pond, watching the fish rise, and Hatty talked" (81). The singularity of various events (the geese breaking into the garden; the walk along the sundial wall) are framed in and contained by this narrative iteration. Time in the garden moves in a seemingly endless cycle. 
This cyclical time is contrasted with how Tom experiences his hours in the daytime of the Kitsons' flat, a place of chronos, where "[t]ime was marching steadily onwards in the way it is supposed to go: from minute to minute, from hour to hour, from day to day" (98). His sojourn there (and his access to the garden) is, as is characteristic for these stories, temporary: eventually he will be forced to leave the house and the garden behind and return home. The sense of endless presentness that Tom gains through the many thirteen o'clocks that he lives through, however, comes to infect his daytime hours: "His home now seemed a long, long misty way away; even Peter [Tom's brother] was a remote boy with whom he could only correspond by letter and never play" (63). Tom is at first, able to forestall linearity, delaying his inevitable departure first by asking to stay longer, and then by being too sick to leave. But eventually, the march of time asserts itself and explodes Tom's (and the reader's) "sense of indefinite postponement." ${ }^{26}$ It happens when Tom's Aunt Gwen walks into his bedroom one morning with a letter from his mother summoning him home. She brings him tea, and tells him: "It's time to get up" (Tom's Midnight Garden 148).

From this point, chronos is brought heavily to the forefront: the next chapter is titled "Next Saturday," and the narrative (as in Chimneys of Green Knowe, published the same year) becomes a fraught and anxious countdown, filled with clear time-stamps. Tom next enters the garden "that Tuesday night" (154), and he leaves early to go to bed and think. "That Wednesday night" (166), his visit is cut short by his Aunt getting out of bed, and Tom wakes miserable and resentful on Thursday morning. On Thursday night, Tom and Hatty leave the garden and skate to Ely, after Hatty coaxes him: "The garden will always be there" (177). She is wrong. Tom falls asleep on the way home, and wakes distraught and resentful in his own bed on Friday morning. On Friday night, the door to the garden has closed

\footnotetext{
26 This phrase comes from a poem called "Children" by Bill Manhire, which begins: "The likelihood is the children will die / Without you to help them do it." Collected Poems (Wellington: Victoria University Press, 2001) p120.
} 
forever: instead, he runs into the dark, paved courtyard that had replaced it in his present. This is depicted as both emotionally and physically shocking:

His bare feet fell onto cold stone; he knocked against a tall metal thing, and its lid fell off and rang upon stone again. He shied away and still ran on in the direction of the yews, but long before he reached trees, crashed into a wooden fence. [...] He turned and ran then, like a rat with the dogs after it, back into the house. (201202)

For the entire last week of his stay, Tom is "a rat with the dogs after it," chased by slowly encroaching minutes. The reader runs frantically with him, and, like him, is unsure quite what to hope for.

This inevitable ending is no surprise: from the very beginning of Tom's adventures, it is made clear that his time there cannot last, if by nothing else than by the incessant ticking of the grandfather clock. But there is more. Indeed, Hatty feels the pressure of time long before Tom does: "Not only on that first day of meeting, but on all the days following, her secrets and stories poured from her with haste and eagerness as though she were afraid that Tom's company would not be hers for long" (81).

Both Tom and reader are made peculiarly aware of Tom's status outside of time during his adventures in the garden. He is only able to enter the garden at thirteen o'clock, already a time that does not exist. He enters it for the first time at a liminal hour, the time "between night and day, when landscapes sleep" (40). Further, there is the fact that Tom's presence in the garden of the past is a ghostly and tenuous one. He has no real weight or mass; he can move through doors and walls; and he seems to be invisible to the people there: Hatty and the gardener Abel are the only inhabitants ever aware of his presence.

Tom's ghostliness makes very real the link between time and mortality that is alluded to - or perhaps more accurately, contained within - the idea of the eternal, suspended moment. Death is overtly referenced in the fight that Tom and Hatty have over who, 
between the two of them, is the ghost. "You're dead and gone and a ghost!" Tom yells at her, and is answered by tears: "I'm not dead - oh, please Tom, I'm not dead!" (106). Tom's strange, half-life in the garden is shown to be untenable, if by nothing else, than by Hatty, who over the course of Tom's visits, matures and turns her mind to the world beyond the garden walls. Even within the magical time and space of the garden, it is Tom who is shown to be strange and unnatural in his failure to grow. Further, death has already touched this garden, in the little figure in black that Tom encounters in one of his visits, who turns out to be Hatty herself, newly orphaned and lost to "desolate, ceaseless crying"(98). "Tom had never seen a grief like this" (97), we are told. He asks her what she is crying for, and she tells him, "For home! [...] For my mother - for my father!" Tom also longs for his mother, for his father, for his brother. He cannot stay with the Kitsons, and his departure is inevitable.

The shadow of grief - of loss, and ending, and transience - is inscribed onto the garden's physical setting, too. The asparagus beds, for example, are arranged in "long, gravelike mounds" (42), and mortality is found in the image of the yew trees "humping their shapes" down the garden. The yew is a traditional symbol of (im)mortality, and is often found in English graveyards. The garden is what Gaston Bachelard calls "eulogised" space (The Poetics of Space xxxv), space that is coded as already having been lost, and it is here that Pearce's work diverges from the increasingly desperate nostalgia of Boston's Green Knowe series. The garden of Hatty's memory has already disappeared in Tom's present, subdivided and paved over, made a space for dustbins. Further, one of Tom's first experiences in the past is his witnessing of the great fir tree in the garden being struck by lightning:

he saw the tree like one flame, and falling [...] stretching its length - although Tom did not know this until much later - along the grave-beds of the asparagus in the kitchen garden. (56)

The fact that the fir is standing the next time he visits (evidence in itself of the garden's large shifts in time) cannot erase the fall that has already happened, and will inevitably happen. 
Hatty tells Tom much later, when she is Old Mrs Bartholomew, again an outsider in her own home, that the moment the fir tree fell was the moment she knew "that the garden was changing all the time, because nothing stands still, except in our memory" (212).

The last chapter, "A Tale for Tom Long," represents a reunion and an affirmation of continuity. Hatty is revealed to have become Old Mrs Bartholomew, and the function of memory (adult memory in particular) in the creation of the midnight garden is made clear: it is Old Mrs Bartholomew's dreaming, remembering mind, her longing to recapture herself as Hatty, that allows Tom entrance. Mrs Bartholomew slips into Hatty's old role as storyteller, and in this last chapter, tells Tom a tale: this time the true story of her life and love and loss since their last meeting. They part as incongruous equals:

He ran up to her and they hugged each other as if they had known each other for years and years instead of only having met for the first time this morning ... Of course, Mrs Bartholomew's such a shrunken little old woman, she's hardly bigger than Tom anyway: but you know, he put his arms right round her and he hugged her goodbye as if she were a little girl. (218)

The book ends, then, as it began, with grief at the loss of a garden, and with an enforced leave-taking. The crucial difference is that neither Tom, nor Hatty, are alone to face it. The last chapter of Tom's Midnight Garden is a narrative demonstration of the workings of children's literature and the generative gap at its centre: age tells youth a tale, a tale of the past and present, of both memory and the promise of one. This tale connects the speaker and the listener across time. The goodbye hug between Tom and Hatty is a potent image: this story, like all time-slips, insists on an ending (in this case, a goodbye), but also on consolation. 


\section{Chapter Six}

\section{There and Back: Alternate World Fantasy}

Space that has been seized on by the imagination cannot remain indifferent space subject to the measures and estimates of the surveyor. It has been lived in ... - Bachelard, The Poetics of Space

From its origins in the Victorian period, children's fantasy has demonstrated a strong impulse to remove the child from the everyday world and place it in an Elsewhere: witness Alice's Wonderland, the watery underworld inhabited by Tom as a water-baby, or little Diamond's sojourn in the land at the North Wind's back. These fantasies of place find their origin (as does the entire concept of a dedicated children's literature) in the so-called "discovery" of childhood. When childhood was conceived of and acknowledged as a state apart, "important in itself, not simply as a preparation for maturity" (Grylls, Guardians and Angels 109), writers of children's fiction began, in literary terms, to set the child apart, manipulating the description of place and space inhabited by their child characters to reflect the child's perceived difference in kind.

This impulse to set the child apart in a fantastic space (a space other than this one) is intimately linked to Victor Watson's conception, discussed in the last chapter, of the cultural space being created in children's literature. Watson notes the preponderance of titles which "openly declare" the importance of ideas of space or place in fiction for children:

Alice in Wonderland, Through the Looking-Glass, The Secret Garden, The Wizard of Oz, Tom's Midnight Garden, The Way to Sattin Shore, Where The Wild Things Are. The last is particularly significant because Sendak could easily have called his picture book The Wild Things, or Max and the Wild Things, but he chose to stress the place - as he did in Outside Over There and In the Night Kitchen. (The Possibilities of Children's Fiction 11) 
Watson puts this emphasis on place down to the adult-child relation at the centre of the genre, to what he calls - in direct counterpoint to Jacqueline Rose - "the possibilities of children's fiction." The bridging of the gap between adult and child that the genre attempts to perform, Watson asserts, causes "many writers [to] require a shift of ground, as if writing about children brings into play an irresistible imperative to define a 'magical' space" (11). In other words, the gap, both spatial and temporal, between adult and child (a gap which, again, itself finds its origin in the conception of childhood as a state separated from adulthood, to be observed and described from a distance) expresses itself spatially, in the invention and description of alternate worlds.

Nowhere is this more evident than in alternate world fantasy, which makes the shifts of ground Watson alludes to explicit, and places them at the centre of plot and theme. C.S. Lewis's Narnia Chronicles have given rise to generations of readers for whom every wardrobe and closet door can become a potential portal, a way through to a magical land; Diana Wynne Jones's Chrestomanci stories describe an entire series of parallel worlds and parallel selves, an unfolding of potential lives. Where Philip Pullman's His Dark Materials trilogy depicts the journey from world to world as an act of violence (the boundary between worlds is cut open with a knife), the journeys themselves are both thrilling and, ultimately, rift-healing. J.K. Rowling's Harry Potter books posit a magical world that, paradoxically, shares the same space as the real world, unfolding out of narrow gaps and disused cupboards and the space between train platforms.

We have seen that toy characters, animal characters, and ghost characters serve to make explicit certain qualities that we culturally ascribe to childhood, and that these qualities serve in their turn to illuminate points of tension and connection in the adult-child relation. Time-slip fantasy manipulates temporality around its child characters in ways that locate that cultural childhood's relation to adulthood in time. Alternate world fantasies, similarly, are turned to this end when they are written to, of, and for children: they work to 
imagine, construct, and manipulate physical space to shape and reflect the childhoods that inhabit them. And these childhoods are, as always, imbued with the sense of an ending.

To begin with, the magical spaces of the alternate worlds in these fantasies are intimately aligned with the childhoods of their protagonists: it is childhood, in these stories, which is invested with the power of movement between and across worlds. The children who make it into Narnia, for example, are only allowed access as long as they remain children. They slowly age out of their ability to adventure there, and in The Last Battle (the final book in the Chronicles), Susan Pevensie is missing altogether, having become "interested in nothing now-a-days except nylons and lipstick and invitations," and being "a jolly sight too keen on being grown-up" (124). Lyra Belacqua's world-hopping in His Dark Materials, too, must end with the onset of maturity, and the other-worldly voyages of Christopher Chant, Diana Wynne Jones's future Chrestomanci, are linked to his childhood, and its cultural combination of innocence and ignorance: he knows nothing of his special status as Chrestomanci, and is able to do the impossible by virtue of not knowing its impossibility. This is an idea that emanates from Wordsworth's articulation of the Romantic child: these are beings on whom the "shades of the prison house" have not yet quite closed ("Ode: Intimations of Immortality," line 67).

Mikhael Bakhtin has used the term "chronotope" to denote the way that a narrative organizes character and event in time and space, and his formulation (which makes clear, too, how interconnected, indeed indivisible, time and space are when it comes to setting in narrative), speaks directly to the particular forms of literary manipulation at issue in the invented, magical spaces of alternate world fantasy. According to Bakhtin's conception, a chronotope is both subjective and ideological, highly dependent on the placement of the observer. This has a direct application to the generative gap between adult and child that gives rise to the construction of childhood in children's literature. Rosemary Ross Johnston, in "Childhood: A Narrative Chronotope," makes precisely this point. Johnston identifies a number of characteristics that define literary childhood as a chronotope, among them the 
fact that it is often pedagogical, and that it is viewed from the outside. These characteristics will be familiar from my discussion of the origins of Victorian fantasy in particular: they are a direct cause of the Elsewheres that are so prevalent in the fantasy of that period. Most crucially for our purposes here, however, Johnston defines childhood's chronotope as marked by what she calls an "ethics of hope" (58), one founded in the ways that adults project the future they hope for as well as the past they long for onto the literary child:

With some notable exceptions, one of the features of a narrative chronotope of childhood is a present infused with a future, whereas what many books for adults offer is a present infused with a past. The orientation towards the future can even be seen in books where the time that is being constructed is a sentimental version of pastoral perfection [...] constructed in retrospect by adults who would like it to remain sacrosanct, even though they know this is impossible. It, too, is time with a forward thrust, but the thrust does not come from an excitement and growth within, but is an inevitable, sorrowful propulsion by immutable forces without. (58-59)

This conception of "future-in-the-present" is particularly resonant in alternate world fantasy, this sets it apart from the other sub-genres being considered. Other-world fantasy relies, in ways we have only seen so far in the Arthurian sagas, on the child as the subject of prophecy, on the child as the figure on whom the future rests. The fate of Narnia, Lewis's pastoral battlefield, rests on the shoulders of the children who make their way from here to there; Christopher Chant, later Chrestomanci, is responsible not only for the magical administration of the related worlds, but for their very survival; Lyra and Will, Pullman's protagonists, are explicit Adam and Eve figures, charged with unmaking and remaking the universe; Harry Potter is not only the Boy Who Lived, but the boy who will die to save the wizarding world. Alternate world fantasies do not only (though they do) construct spaces which are specifically designed to reflect cultural childhood, with its literary qualities of pastness, snugness, vitality and secrecy; and they do not only (though they do) construct 
worlds in which death can be, and is, made manifest and given literal presence in the text. They make questions of vitality and mortality even larger and more momentous: in these fantasies, the vitality and mortality of child characters is overtly tied to the fate of worlds entire.

C.S. Lewis's Narnia Chronicles (1950-1956) puts its child protagonists squarely at the centre of Narnia's fortunes. Lucy Pevensie stumbles through the back of a wardrobe and into a whole other world in The Lion, The Witch and the Wardrobe (1950) ${ }^{27}$. Narnia is a magical land of Talking Beasts and sentient trees, a land straight out of a storybook, but when Lucy finds her way in, it has been frozen into stasis. Under the sway of the White Witch, the world has been locked into a hundred-year frost, a state in which it is "[a]lways winter and never Christmas" (23). Lucy, and her siblings Susan, Peter, and Edmund take on the task of freeing Narnia from this freezing enchantment; they become Kings and Queens of Narnia and usher in its Golden Age. When the children return in Prince Caspian (1951), a thousand Narnian years have passed, their Golden Age is the stuff of myth and legend, and the creatures and Talking Beasts of Narnia have been driven underground. Here, the children take on Narnia's re-enchantment, and the freeing of its people. In The Voyage of the Dawn Treader (1952), Edmund and Lucy, along with their cousin Eustace, undertake another kind of quest for restoration, joining King Caspian on his search for Narnia's seven banished Lords. In The Magician's Nephew (1955), the children Polly and Digory are

\footnotetext{
${ }^{27} \mathrm{I}$ am discussing the books in their original order of publication rather than in their "recommended" chronological order. Certainly The Magician's Nephew is arguably far more effective as a prequel to an already established series than as an introduction. The image of the lamppost planting itself in that book is merely an oddity if the reader has not already encountered it (it is a far more powerful image as the origin story of a known anomaly than as an introduction); the characters discuss the potential history of the place they are watching come alive in a way that owes its entire effect to the gap between what they know of the history of Narnia and what the reader (having read the earlier instalments) knows of it:
}

"I wish we had someone to tell us what all these places are," said Digory.

"I don't suppose they're anywhere yet," said Polly. "I mean, there's no one there and nothing happening. The world only began today."

"No, but people will get there," said Digory. "And then they'll have histories, you know." (The Magician's Nephew 177) 
protagonists in and witnesses to Narnia's birth; in The Last Battle (1956), all of Narnia's child heroes (save Susan) are witness to Narnia's death.

It is true that, as Jewel the Unicorn says in The Last Battle, "the Sons and Daughters of Adam and Eve were brought out of their own strange world into Narnia only at times when Narnia was stirred and upset" (82). The effect of this treatment of child as saviour is to directly counter the power-relations of the primary world, and make the choices and actions of the child characters (and the Child more generally) literally momentous. Laura Miller, in her powerful reader's memoir of the Narnia Chronicles, The Magician's Book: A Skeptic's Adventures in Narnia, points out the centrality of this literary agency in other-world fantasy. According to Miller, Narnia, and by extension all alternate world fantasy, moves beyond "the morality of childhood, where the choice was between obedience and naughtiness. The morality of Narnia was grown-up, a matter of good and evil. [...] To me, the best children's books gave their child characters (and by extension myself) the chance to be taken seriously" (61). Alternate world fantasies make space for power.

The momentous matters in which child characters are embroiled in these stories are always matters of life and death, and alternate world fantasies mirror those we have already seen in constructing a cultural childhood that is defined by life and by death. It is worth iterating here that Bakhtin's chronotope describes placement in time as well as in space: the Narnia Chronicles are a particularly good example of how interconnected (indeed, indistinguishable) time and space are in literary setting, and particularly in the worldbuilding of fantasy. Lucy, when she falls through the back of the wardrobe, tumbles into another when as well as another where; she falls from summer into winter, and while she sits and has tea with a faun, mere seconds pass back in the world with the wardrobe in it. She returns to that world, in a sense, never having left. Time, in Narnia, is deliberate in its depiction of a constant tension between endlessness and fleetingness, and in its foregrounding of time's inevitable operation. Indeed, it foregrounds time's inevitable end: after the events of The Last Battle, in which Narnia itself dies, Narnia is entirely eulogised, 
and wholly a figment of memory. No amount of peeking hopefully into closets and wardrobes by any number of enchanted readers will bring anyone there again. Perhaps the half-hope that keeps successive generations of readers trying anyway is its own manifestation of eternality.

Much is made in the Chronicles of the difference between the passage of time in Narnia compared to that of the children's primary world. The Pevensies, having walked into Narnia and grown into young adulthood there as Kings and Queens (this seems an age, but is probably only about fifteen Narnian years at the outside - a period of time that shrinks alarmingly the older the reader gets), tumble back out of the wardrobe and back into their childhoods on "the same day and the same hour of the day on which they had all gone into the Wardrobe to hide" (The Lion, the Witch and the Wardrobe 170). In Prince Caspian (1951), the Pevensie children return to Narnia only a year later in their own time to find Cair Paravel a desolate ruin "so forsaken and long ago" (34), and themselves the figures of mythic legend as well as of prophecy:

It is the magic horn of Queen Susan herself which she left behind her when she vanished from Narnia at the end of the Golden Age. [...] It may have the power to call Queen Lucy and King Edmund and Queen Susan and High King Peter back from the past, and they will set all to rights. (72)

Here, the Pevensies are explicitly made subject to the "once-and-future" quality of literary childhood, and further, made embodiments of a Golden Age. The fact that Narnia runs on a different and much faster time-scale than the children's primary world is more than once used to this shocking, fleeting effect: having met young Prince Caspian as a boy (in Prince Caspian) and followed him on an adventure over the high seas as a young King (in The Voyage of the Dawn Treader), the reader shares Eustace's consternation at his appearance in The Silver Chair: 
... to see that old man with a white beard, and to remember Caspian as he was the morning we captured the Lone Islands, or in the fight with the Sea Serpent - oh, it's frightful. It's worse than coming back and finding him dead. (47)

These large jumps between time-streams, which underscore the intense and fleeting qualities of literary childhood, are countered in the Chronicles by a peculiar dragging out of time inside Narnia itself. Indeed, time inside Narnia can seem endless. See, for example, the oddly static voyage the children undertake on the sunless sea in The Silver Chair:

when they woke, everything was just the same; the gnomes still rowing, the ship still gliding on, still dead blackness ahead. How often they woke and slept and ate and slept again, none of them could ever remember. And the worst thing about it was that you began to feel as if you had always lived on that ship, in that darkness... (158)

There is a similar effect in Edmund's sleigh ride with the White Witch in The Lion, The Witch and the Wardrobe, and in the sea journey in The Voyage of the Dawn Treader (1952), to name only a couple of examples. This tension between the fleeting and the seemingly interminable is also evident in the treatment of Narnia's history more generally. Narnia's entire span is depicted (and experienced by the reader) as a series of bright and fleeting days over the space of only a few years. Lucy encounters Narnia for the first time as a child of eight; only eight years later, at the age of sixteen, Lucy returns to Narnia for the last time to witness its extinction. Lewis's narrator does try to counter this effect by emphasizing the length of Narnia's history compared to the relative brevity of human adventure there:

In between their visits there were hundreds and thousands of years when peaceful King followed peaceful King till you could hardly remember their names or count their numbers, and there was really hardly anything to put into the History Books. (The Last Battle 82) 
But the narrator's efforts are not wholly successful. What the narrative shows is far more impactful than what is left out, and, particularly in the original order of publication (in which the founding of Narnia in The Magician's Nephew is followed only a year later by its death in The Last Battle), fleetingness is the impression that remains. It is only three pages after the assurance of immeasurable history quoted above that brevity asserts itself again when Tirian, the Last King of Narnia, learns of the sack of Cair Paravel, and the death of Roonwit the Centaur. After a long silence, Tirian says: "Narnia is no more" (The Last Battle 85).

To return to spatial rather than temporal world-building, physical space in Narnia is often constructed and manipulated to the same endless and fleeting effects. In Shasta's slow progress over the desert in The Horse and His Boy (1954), for example, endlessness is expressed in purely spatial terms:

And nothing at all different for mile after mile. Tashbaan would never look any further away. The mountains would never look any nearer. You felt this had been going on for always. (118)

Space in Narnia is characterised by close walls, and by boundless vistas and moving horizons: these two extremes are held in a constant tension. This effect in the stories can extend beyond the bounds of Narnia itself. The Pevensies in The Lion, the Witch and the Wardrobe are evacuated from London, a big city of small and stifling spaces - Professor Kirke's country house "was a far larger house than [Lucy] had ever been in before" (10) - to a house that seems big enough to be a universe: "the sort of house that you never seem to come to the end of, and [...] was full of unexpected places" (11). In that large house there is the small space of the wardrobe, which turns out to contain a country, "all that lies between the lamp-post and the great castle of Cair Paravel on the eastern sea" (17).

For all of its paradoxical expansiveness, however, Narnia, as an invented world is a model of the cultural space that Victor Watson claims is the work of children's literature: it is full of the small, snug spaces that Jerry Griswold finds so characteristic of the genre (Feeling Like a Kid 5). Indeed, all five of the qualities that Griswold identifies as marking a literary 
work out as of childhood and for children are evident in Narnia. There is Scariness in the threat of injury or death - Narnia is, after all, a battleground, as well as a mythical version of a medieval past. There is Smallness in the community of monopods in The Voyage of the Dawn Treader; Lightness in the image of Fledge (once Strawberry, the London Cab Horse), winged and flying over a walled garden in The Magician's Nephew; and Aliveness in the Talking Trees and Talking Beasts of Narnia ("Hail, Aslan. We hear and obey. We are awake. We love. We think. We speak. We know" (The Magician's Nephew 140)). But, most importantly in terms of its construction of space, Narnia is Snug: its most memorable images are of the book-lined comfort of Mr Tumnus's cave, or the hammock-filled clutter of the beavers' house. This is space constructed to mirror and represent, as well as to house, cultural childhood. To Jerry Griswold's list of characteristics, however, Mortality must be added: the warm, life-filled spaces of Narnia (the places where one eats) lie alongside the vast cold halls of the Witch's castle with its courtyard full of statues, the vast, dead expanses of the Sunless Sea, the arid desert, and the world of Charn, laying empty under a dying sun. Here, as in all alternate world fantasies for children, mortality extends beyond the individual characters to the world itself.

In The Voyage of the Dawn Treader, the third of the seven Chronicles, Lucy, Edmund and Eustace join Caspian on a voyage to Aslan's country, the land beyond the world's end. While there is a characteristically Narnian tension between the snug and the boundless in the image of the small, homelike ship on the vast sea, the more important point is the ship's destination: "the end of the world," as so much in Narnia, has a temporal as well as a spatial connotation, and this is the Chronicle in which intimations of Narnia's end begin appearing. A deadly ring is thrown onto a rock projection where we are told, "it may hang until that world ends" (89). The stone knife that sacrifices Aslan in Lion (note the emphasis on life out of death, fitting for a world constructed so strongly on a religious notion of life after death) is put on the Dark Island "to be kept in honour while the world lasts" (153). Instead of an image of permanence, this raises the spectre of a time beyond which the world will not last. The next chapter is called "The Beginning of the End of the World." 
This emphasis on the ending to come is only reinforced in later Chronicles: the major part of The Silver Chair takes place in a literal underworld. "Many come down, and few return to the sunlit lands," we are told. "It is said that they will all wake at the end of the world" (155). In The Last Battle the end arrives: its first chapter is titled "In the last days of Narnia." Continuing the theme of paradoxical space, our former child heroes walk through a stable (an overtly Christian symbol) into a land that reduces even the vast world of Narnia to insignificance:

"I see," [Lucy] said at last, thoughtfully. "I see now. This garden is like the Stable. It is far bigger inside than it was outside."

"Of course, Daughter of Eve," said the Faun. "The farther up and the farther in you go, the bigger everything gets. The inside is larger than the outside." (The Last Battle 162)

Much like the Christian fantasist George MacDonald before him, Lewis conceptualises death as more life. It is this conception which leads, ultimately, to a bloodbath disguised as a happy ending, or a happy ending disguised as a bloodbath:

"There was a real railway accident," said Aslan softly. "Your father and mother and all of you are-as you used to call it in the Shadowlands-dead. The term is over: the holidays have begun. The dream is ended: this is the morning." (165)

One could be forgiven, in the absence of faith, for feeling ambivalent about this framing of the death of a family. But taken on its own terms, and even without the Christian overlay, this ending is the fulfilment of the wish at the heart of these stories: to be let in to the magical world and to never have to leave. Drawing taut the link between the life of the child and the life of the world is the fact that the protagonists of The Magician's Nephew, twelve-year-old Digory and eleven-year-old Polly, both of whom were present at Narnia's birth, are, as elderly people restored to youth, present for its extinction. Narnia is born, thrives, declines, and dies in the fleeting span of a human life. 
Diana Wynne Jones's Chrestomanci sequence also ties the fate of the world to the life of particular children. In Charmed Life (1977), the care and protection of the world of Cat Chant (and indeed, the eight other parallel worlds with which it is connected) will eventually rest on Cat's shoulders. Cat is a nine-lived enchanter (through a mechanism by which the lives that would in anyone else be spread over the nine worlds, living parallel and concurrently, are concentrated in his world, in his one body). He is a rare being, destined to become Chrestomanci, overseer of magic in all the related worlds. This makes Cat special and powerful; it makes his fate and his decisions momentous.

In this context, it is interesting that Cat spends much of the book so thoroughly failing to be an active protagonist in his own story; in Narnian terms, he is far more a Eustace Scrubb than a Pevensie. It is Cat's psychopathic sister, Gwendolen, who directs the action. She steals Cat's power, and, it is slowly revealed, uses up Cat's nine lives. Gwendolen is "pleased and golden and glowing" (Charmed Life 17); she is "exultant" (20), and (with Jones's unerring eye for hypocrisy) the "picture of a perfect little girl" (74). Appearances are, for Gwendolen, her sole tool for advancement: the truth is that Cat, the nine-lived enchanter, possesses all of the power, and Gwendolen only the appearance of it. Aware of her looks, and of her status as a glamorous orphan (the children lose their parents on the first page of the novel), Gwendolen wields them both in her own interest. When Chrestomanci offers to take brother and sister in at Chrestomanci Castle, she says: "he was touched at our orphaned state [...]. He's going to adopt us. My fortune is made!" (33). Cat pales beside Gwendolen: he is "cowed" (176); "clinging" (46), and "obedient" (176); he is "damp and weak and almost washed out of existence" (45). Further, he is all too excruciatingly aware of himself as a sorry excuse for a boy, never mind a protagonist. The story is one of Cat discovering, and then coming into, his own status as hero.

Crucially, the struggle between the siblings is depicted in spatial terms: "Gwendolen," we are told, "seemed to expand. Her hair seemed brighter gold, her eyes deeper blue, and her whole manner was glad and confident. Perhaps Cat contracted a little to make room for her - 
he did not know" (16). Cat has contracted to make room for Gwendolen. He loses one of his lives, in fact, to the terrible cramps that come upon him when Gwendolen, in order to take control of them and spend them, makes his lives manifest and squeezes them into a matchbook: she literally cramps him. It is arguable that Diana Wynne Jones chooses alternate world fantasy precisely for the ways that it is possible in such fantasy to manipulate space to these expansive and stifling ends: to use space, in other words, to depict life and its snuffing out.

There is a scene in which Gwendolen, in a fit of pique, magically ushers the dead through a dinner party in order to disturb the guests. Somewhat chillingly, the dead are given a cruel kind of consciousness of themselves:

...bones when they are bewitched have a way of remembering who they were. The dangling skeleton sighed, in a hollow, singing voice, "Poor Sarah Jane. I'm poor Sarah Jane. Let me rest."

Gwendolen waved it impatiently towards the door. It went dangling off, still sighing, and a second skeleton dangled after it, sighing, "Bob the gardener's boy. I din't mean to do it." They were followed by three more, each one singing softly and desolately of who it had been ... (118)

Charmed Life's plot is made possible by its alternate setting, in that the entire novel is driven by the presence of Cat's multiple lives, and the different ways that he loses them (Charmed Life, as a title, is thus both pointedly accurate, and deliberately ironic). The novel's magical setting allows his deaths (the lives that unbeknownst to Cat, Gwendolen has cost him) to be made flesh before him:

The first was like a baby that was too small to walk-except that it was walking, with its big head wobbling. The next was a cripple, so twisted and cramped upon itself that it could barely hobble. The third was the apparition at the window- 
pitiful, wrinkled, and draggled. The last had its white skin barred with blue stripes. All were weak and white and horrible. (119)

There is something deliberately horrifying in Cat's slow realisation that these deaths are his, and in the idea that they have passed without notice. Surely a thing as momentous as a death should be unmissable, but Cat loses six of his lives before he realises what is happening. He does not even recognise his lives when they are front of him: in the scene quoted above, Cat knows only that he is distressed ("Cat shuddered all over. 'Please send them away!' he said" (119)). Jones's cutting irony works to amplify Cat's retrospective horror by making the reader complicit in it. Having laughed at the scene where a fiddle is transformed into a tabby in Cat's arms (a spell performed by Gwendolen, in another fit of pique), the revelation that this transformation murdered one of Cat's lives is a little stomachturning.

Death drives this story, and it also works, even beyond the cramping and snuffing of his own lives, to explain Cat's initial lassitude and paleness of character. After the loss of his parents, Cat does not cry, nor does he think of himself as sad in general ("[n]ot that he was unhappy," we are told, "... [h]e had dozens of friends"). But "at the heart of everything, he felt lost and lonely" (16). Cat's profound detachment is a very realistic function of grief. For all that Jones displays a cutting awareness of the orphan trope in children's literature, and remarks caustically on its aesthetic and plot-driving qualities ("They became celebrities for a time. Everyone was very kind. Everyone said what beautiful little orphans they were. It was true. They were both fair and pale, with blue eyes, and looked good in black" (2)), she is also concerned with how grief might actually work in the lives of the characters, and with portraying grief's ongoing effects.

In this, as in all alternate world fantasy, the details of world-building are placed at the centre of the story, and the spaces that surround and house the child become particularly resonant. The spaces that Diana Wynne Jones constructs in Charmed Life are characterised by their mortal notes. There is Mr Baslam's cottage for example, stuffed with dead animals 
and smells of decay, and the magic tutor's study, with its mummified remains. There is also the kitchen of Mrs Sharp, the children's venal first guardian: the squalor there (the range is "all ash," and "the flies were gathering around the meat for lunch" (30)) provides a comically inappropriate venue for the first meeting of Cat and Chrestomanci, the two most powerful beings in the nine worlds. Jones skilfully turns the kitchen, traditionally the seat of domestic comfort, on its head: Cat finds neither home nor safety there.

Chrestomanci Castle is both the obverse of Mrs Sharp's decaying kitchen, and very like it as an example of deliberately incongruous space: for all of its grandeur, the Castle's main characteristic is hominess. It has a bedroom that Cat feels more at home in than he has anywhere, and a schoolroom that verges on the platonic ideal ("there was a blackboard, a globe, the pitted school floor, and the schoolroom smell. There was that kind of glass-fronted bookcase without which no schoolroom is complete, and the bartered gray-green and dark blue books without which no schoolroom bookcase is complete" (57)). This image will be revisited in the magical school that J.K. Rowling will build for her child wizards in Harry Potter. Indeed, Chrestomanci Castle (as Hogwarts will) melds the storybook castle with the storybook boarding school, constructing a childhood space that owes its effect to literary tradition rather than to lived experience. This setting is used for a certain irony; it inflects the child characters the Castle houses in ways that underscore their relative complication and ambivalence as cultural constructs. Gwendolen only looks like a storybook heroine, and Cat only looks like a bit player: only one of them belongs in the Castle, and it is not the one the reader expects. The Castle is also, crucially, a magical space, serving to both halt and reverse Gwendolen's expansion at Cat's expense. Where Cat finds comfort (Jerry Griswold would call it "snugness") in the magic-blanketing effect of the Castle (he compares it to a feather quilt and says it's "like when it snowed in the night" (50)), Gwendolen finds herself stifled in her turn: "There's something about this Castle. It's a bad influence, and a deadness. It's squashing the life and the witchcraft out of me. I can hardly breathe" (48). 
The Castle, then, is characteristic of spatial construction in alternate world fantasies in its magical power, its snugness, its mortal slant, and its evocation of a peculiarly literary historical past. This is true of all the alternate world fantasies being discussed in this chapter: in Pullman's His Dark Materials, air travel is managed, for example, by hot-air balloon rather than by aeroplane; Harry Potter, once ensconced in Hogwarts (another storybook castle), scratches out his homework on parchment, with a quill. Lewis's Narnia is strongly evocative of medieval romance; the world of Chrestomanci, on the other hand, is far closer to the Edwardian. This is made clear on the first page of Charmed Life, which describes the day that Cat and his sister became orphans after their parents drown on a Sunday jaunt on a paddle steamer:

They set out in great style, Gwendolen and her mother in white dresses with ribbons, Cat and his father in prickly blue-serge Sunday suits. It was a hot day. The steamer was crammed with other people in holiday clothes, talking, laughing, eating whelks with thin slices of white bread and butter, while the paddleboat steam organ wheezed out popular tunes... (7)

As well as ensuring that death and displacement drive the story from the first, this scene in its physical detail - the ribbons, the prickly serge Sunday-best, the whelks, the paddle steamer itself and the wheezy organ music that provides a horrifyingly incongruous soundtrack for the its passengers to drown to - speaks to deliberate archaism. It seems that when writers invent worlds for child characters to inhabit, they are impelled to look to the historical past. This archaism is a direct result of writing to and of childhood, an exercise that is necessarily retrospective. "The child," Valerie Krips writes, "is in fact the ultimate conduit to the past, representing not only the most intimate past of self, but the past of the culture as well" (The Presence of the Past 24): the worlds writers build for children cannot help but reflect this cultural function.

But this pastness is not free from complication, and childhood as a cultural value pulls in contradictory directions. Childhood, as we have seen, evokes not only memory, but 
an intense and fleeting present vitality; not only the long-ago, but the yet-to-come. This, too, is reflected in these other-world fantasies, which uniformly (and somewhat paradoxically) insist on the present tense of their historical settings. Diana Wynne Jones herself is pointed about the fact that Cat's world, as old-fashioned as it is, is a version of the present day. In a conference paper entitled "Inventing the Middle Ages" (which mostly discusses How Not To Do It), she writes:

Children as a group have almost no sense of history at all. They are by their nature the most forward-looking section of the population. [...] For this reason they are not going to be very interested in books that are not about here and now and what is to come. When I first started writing for children, I made a conscious decision to write about the present day (or a semblance of the present day set in an alternative world) and not to go out of my way to inculcate a sense of history that isn't there. ("Inventing the Middle Ages" 200)

This is a forceful statement of a self-conscious writerly stance, and Jones's work is distinctive in its sharp-eyed and even slightly sardonic rebuttal of sentiment and nostalgia in connection with childhood. There is even an in-universe explanation for Chrestomanci's archaism (one we will see revisited in Harry Potter): a world with magic in it has no need for technological advancement. But the archaism itself, in conjunction with Jones's contradictory insistence on the "present day," serves to make the way setting is constructed in her fantasy to evoke the past of the self and of the culture only more notable. Adults writing to children, it seems, cannot escape their own "sense of history," whatever their opinion about what children are interested in. Jones's conception of children as "the most forward-looking section of the population," however, aligns exactly with Rosemary Ross Johnston's description of the narrative chronotope of childhood as "a present infused with a future" ("Childhood: A Narrative Chronotope" 58). And this is where the pastness of literary childhood collides with the potential future of which the child is also so emblematic: this collision explains the centrality of prophecy in these stories (prophecy is, after all, a voice from the past speaking 
into the future). It explains why Cat's fate is entwined with the fate of his world and the parallel worlds connected to it.

Until Gwendolen departs at the end of the story, sliding Janet Chant, one of her alternate lives from another of the nine worlds, into her place, relatively little is made in Charmed Life of the Related Worlds that make up the multiverse of the Chrestomanci stories. They are barely mentioned: our first hint is Mr Baslam telling Gwendolen that dragon's blood must be smuggled in from another world almost halfway through the story. When Janet arrives, we are told, in the note that Gwendolen leaves for her, that the separate worlds are formed when "there is a big event in History like a battle or an earthquake when the result can be two or more quite diferent things. Both those things hapen but they cannot exist together so the world splits into two worlds witch start to go diferent after that" (131, sic). The fourth book in the series, The Lives of Christopher Chant: The Childhood of Chrestomanci (1988), is, in contrast, focused squarely on the multiverse and its mechanisms and organisation, turning from the idea of living in an elsewhere to the idea of travelling to an "Almost Anywhere" (The Lives of Christopher Chant 9). It is set twenty-five years before the events of Charmed Life, and, as the subtitle says, tells the story of the childhood of the present Chrestomanci, Christopher Chant. It tells the story, more precisely, of how he lost most of his lives, just as Charmed Life tells the story of Cat's deaths.

Christopher's childhood in The Lives of Christopher Chant is as intimately tied to mortality as Cat's will be twenty-five years later. Jones uses the plot device of travel between the Related Worlds to drive this point home; it begins in the very first line of the novel: "It was years before Christopher told anybody about his dreams" (7). Christopher's dreams are of travel: "The dreams always began the same way. Christopher got out of bed and walked around the corner of the night nursery wall [...] he went up the path, around a large rock, into the part he always thought of as The Place Between" (8). This Place is "formless and unfinished" (26), and "some of it was hard and steep, some of it piled and rubbly, and none of it had much shape" (8). It is filled with "such thousands and thousands of valleys, high up, 
low down, turning off at every angle you could think of, and some valleys turned off other valleys" (26), and each valley a portal to the series of worlds that make up Jones's multiverse.

The Place Between the Worlds in the Chrestomanci stories is not part of any one world but a portal to all of them. In this it is very like Lewis's Wood Between the Worlds, described in chapter three of The Magician's Nephew. The Place and the Wood seem, at least at first, to be constructed as diametrical opposites: where The Place is a dusty, colourless "left-over piece of the world, from before somebody came along and made the world properly" (The Lives of Christopher Chant 8), the Wood is a font. It is "very much alive," and "a rich place: as rich as plum cake" (The Magician's Nephew 40). But the two visions of liminal and in-between space might actually be more alike than different. They are both places of embarkation: "Christopher always knew [...]," Jones tells us, "that you could get to Almost Anywhere from The Place Between" (Christopher Chant 9), and Lewis tells us that there are "any number of pools in the wood" (The Magician's Nephew 49), all leading to a different world. Laura Miller calls the Wood (using temporal metaphor) "a unitary moment, containing everything, the pause before a story is told, in which nothing has happened and so anything might" (The Magician's Book 296); The Place Betweem, being, so to speak, a somewhere from before where existed, has the same quality of unknowable potential. But similarly, both The Place Between and the Wood are shown to be spaces where staying (and living) are impossible. Christopher knows that The Place Between repels life:

Right from the start of his dreams, he had known that The Place Between liked to have everything that did not belong sent back to the place it came from. That was why he always climbed back to bed faster than he did when he climbed out to a new valley. The Place pushed him back. (The Lives of Christopher Chant 27)

The Wood Between the Worlds, for all its abundant life, hoards that vitality at the expense of those who enter it. The lush trees are evidence of growth, but there are "no birds, no insects, no animals, and no wind" (The Magician's Nephew 40)). Further, it is outside the passage of time ("it seems to be always the same time in the Wood Between the Worlds" (50)): as such, 
the Wood is paradoxically deathly. The children almost lose themselves inside it, struggling to remember who and what they are. When Digory tells Polly there is no rush to leave, she replies: "I think there is [...]. This place is too quiet. It's so - so dreamy. You're almost asleep. If we once give into it, we shall just lie down and drowse forever and ever" (43). This recalls Carroll's Alice in her own Wood Where Things Have No Name. Like Alice, Polly and Digory find solace in their remembering of themselves. The Wood's oppressive peacefulness and Lethe-like forgetting is as inimical to the business of living as the Place's dusty, left-over inhospitality.

The mortal notes in Jones's multiverse expand beyond the lifeless Place Between. The multiverse in The Lives of Christopher Chant is the setting of a smuggling trade that deals in death. Dragon's blood, for example, costs the lives of its donors; mermaids are butchered for parts. Christopher Chant, however unwittingly, makes this deadly work possible through his rare and valuable ability to cross from world to world. He is exploited by those whose business it should be to take care of him, and it costs him a number of his own lives. Christopher's own mortality is insisted upon, and directly related to the shiftings of ground in the story. Because all of his lives are clustered into one world, when Christopher loses one of his lives on his travels (in dreams that are not quite merely dreams), it causes a parallel death in his waking world. This leads to a peculiar form of insistence on the fact of mortality: Christopher, when he dies, must always die twice. He catches a spear through the chest in a related world, and is then impaled by a curtain rod in his own bedroom; he is torched by a dragon, and then by a fire on the heath; he breaks his neck again and again. In contrast to Cat, whose horror is mostly retrospective, Christopher is spared no gruesome detail of his own deaths as they are happening, even if they do not seem to permanently take. After dying from a hook to the head in another world, for example, Christopher is done in by a cricket bat in his own: "He remembered hearing several other distinct cracks, just over his left ear, as if the bones of his skull were breaking up like an ice puddle" (116), and he wakes up on a slab in the morgue. Here, as in Charmed Life, the magical setting of the story is put to the 
task of tying mortality directly to the child protagonist without the need of a metaphor in the middle: Christopher's deaths are given physical presence, oriented in space.

The entire impulse of Philip Pullman's His Dark Materials trilogy is towards the manifestation of mortality and vitality in physical space. The most distinguishing and memorable characteristic of the world Pullman creates for Lyra Belacqua, his protagonist, to inhabit is that in that world, the human soul is given physical form in the body of a daemon, or literal spirit animal. In Lyra's alternate world, the vital soul is something that can be seen, and talked to, and held close and petted. Pantalaimon, Lyra's daemon, is as fully rounded a character as Lyra herself, for all that they are facets of the same entity. Further, this embodiment of spirit is only a part of a much larger physical manifestation that Pullman's other-world makes possible: Dust, the elementary particle around whose mysteries the entire trilogy revolves, is a metaphor for consciousness and informed thought that is given physical reality in the world of the series. The plot of all three stories centres on the ways in which this Dust can be interacted with directly, and, more crucially, the ways it can be (physically) destroyed.

As in the Chrestomanci sequence (and indeed, if with far less emphasis, in the Narnia Chronicles), His Dark Materials is set in a multiverse: one that Lyra (and Will Parry, the child protagonist who joins the story in the second instalment) move through in their quest to discover the secret of Dust. Lyra and Will spend the narrative encountering the boundaries of their various worlds, and then breaching those boundaries. They are both embodiments, as children in this type of fantasy seem fated to be, of the future; both are also the subjects and objects of prophecy. The prophecy they are enjoined to fulfil is the literal breaking-down of the boundary between the world of the living and the world of the dead: their ultimate object is to remake Heaven.

Here, the multiverse is conceptualised not as a series of connected worlds accessed from an in-between place, but as interpenetrating, one world laying over the top of another and occupying the same physical space. "[H]ere on this deck," Lyra is told in the first book of 
the trilogy, "millions of other universes exist, unaware of each other [...]. We are as close as a heartbeat, but we can never touch or see or hear those other worlds" (Northern Lights 187). The last page of Northern Lights, however, sees Lyra marching on a bridge of Dust directly into those other worlds, to touch and see and hear them: "Lyra and her daemon turned away from the world they were born in, and looked towards the sun, and walked into the sky" (399).

Northern Lights (1995) is a parallel world fantasy, for all that world-traversing doesn't happen until the very end. It tells the story of Lyra Belacqua, a girl growing up on the streets of an alternate Oxford, only a step up from urchin. Perhaps, in a world where souls manifest in animal forms, Lyra's wildness when we encounter her should not be thought of as odd. She certainly seems an unlikely choice of prophetic subject. She is called savage repeatedly, "a half-wild, half civilized child (Northern Lights 19), whose upbringing after being left behind among the scholars of Jordan College, Oxford (a college with no equivalent in real Oxford), is characterised more than anything by benign neglect:

In many ways, Lyra was a barbarian. What she liked best was climbing over the College roofs [...] to spit plum stones on the heads of passing Scholars or to hoot like owls $[\ldots]$ or racing through the narrow streets, or stealing apples from the market or waging war. (35-36)

Lyra's divergence from the innocent Romantic child of tradition (or, more accurately given the double-pronged ambivalence of the Romantic construction, her perfect embodiment of it) is designed to shock: the narrative insists on pointing out the ways Lyra fails to be quite child-like. Anticipating a battle with the other children thronging Oxford's streets, for example, Lyra "threw her cigarette down, recognizing the cue for a fight" (55). Indeed, Pullman's narrator explicitly derides and denies the pale, Romantic child of adult imagination:

the Scholars [...] would have been unable to see the rich, seething stew of alliances and enmities and feuds and treaties that was a child's life in Oxford. Children 
playing together: how pleasant to see! What could be more innocent and charming!

In fact, of course, Lyra and her peers were engaged in deadly warfare. (36)

It is this very savagery, this likening to a healthy, unthinking animal with an animal kind of bloodthirstiness that marks Lyra out as childish, and, paradoxically enough for the Scholars (but not for the children's writer), as innocent. According to Elizabeth Hale's analysis, discussed in Chapter Two, the kind of ruthless self-absorption Lyra displays is an evocation, rather than a denial, of Romantic innocence. In any case, Lyra's status as a "strange, innocent creature" is put at the foundation of her role in prophecy:

[The Witches] have spoken of a child such as this, who has a great destiny that can only be fulfilled elsewhere - not in this world but far beyond. Without this child, we shall all die. So the witches say. But she must fulfil this destiny in ignorance of what she is doing, because only in her ignorance can we be saved. (175-6)

Jordan College, Oxford, is Lyra's particular cloister, a place of "jumbled and squalid grandeur," marked by age and legacy: "it had grown piecemeal, with past and present overlapping at every spot" (34). The Oxford of His Dark Materials is the real Oxford amplified, a place "where the real and the unreal jostle in the streets [...], where windows open into other worlds" (Lyra's Oxford n.p.). There is the by now familiar insistence on an archaic inflection of the present: Lyra's Oxford is one of antiquated technology, transport and vocabulary. This is the same resonant placement of the past in the present that we find in Diana Wynne Jones's Chrestomanci stories, and in Narnia. Even in its own context, Jordan is old-fashioned, and, at least superficially, a strange place for a little girl to grow up. But it is the home Lyra longs for after her departure from it, for all of its lack of domestic trappings. At a deeper level, it is invested with the same echoes of past, present and future as Lyra herself, a more than apt place to find her at the beginning of her journey. Oxford is depicted as Lyra's own small kingdom, intimately known and claimed. It is a bounded world, with carefully defined spaces and territories. Indeed, the Oxford of our world shares these 
qualities: "The city of Oxford is a city of high walls: stone boundaries that separate off the cloistered seclusion of college lawns and courtyards from a bustling outer network of narrow lanes, market stalls, and shops" ("The Geography of Shadows" 270). This makes it a particularly rich setting for Lyra's childhood, both snug and expansive, and containing both secure bounds and plenty of opportunity to escape them.

One of the most important facets of Lyra's character as she is presented here is the joy she takes in transgression, in breaking bounds. For all that she lives within the walls of Jordan College, and is happy to return there, Lyra's usual haunts are beyond them, in "the irregular Alps of the college roofs" and the "netherworld" of Jordan's subterranean tunnels (Northern Lights 48, 49). Indeed, the reader encounters Lyra for the very first time as she breaks bounds, sneaking into the decidedly adult, forbidden space of the Retiring Room at Jordan. While there, she eavesdrops on a conversation about Dust while hiding in an oak wardrobe: she "found that the wardrobe was bigger than she thought. There were several academic robes and hoods, some with fur round them..." (8). This is deliberately reminiscent of the wardrobe between the worlds in the Narnia Chronicles. Lyra's journey out of her own world begins, like Lucy's into Narnia (if rather more obliquely), from this wardrobe.

The second book in the trilogy, The Subtle Knife (1997), surprises by not opening on an alternate world: it tells the story, at least in the beginning, of Will Parry (aptly named, given the talent he will cultivate with the knife of the title), living with his mother in modern Oxford. This part of the story, reflecting the world of the reader rather than building a new one, underscores how far the imagined worlds of these stories construct and reflect childhood by refusing that construction here. Real Oxford is not depicted as childhood space at all: Will, at twelve, is notable for his unnatural maturity. Will's father is dead, and his relationship with his mentally ill mother is marked in its role-reversal. Will is protector and caregiver, made almost entirely responsible for the safety and security of both of them: "Home," we are told, "was the place that he kept safe for his mother, not the place others kept safe for him" (The Subtle Knife 321-2). Like Lyra, he is described as savage (we see "his 
slim body shivering in a torn linen shirt and his expression exhausted and savage and wary" (336)). Like Lyra, Will is marked out by destiny, chosen by the subtle knife to be its bearer. Using it, Will is able to cut openings between universes, and to allow passage between them. It is telling that Will finds a way out of the world through violence: he is forced to flee after killing a man who had broken into his home. It is precisely Will's capacity for careful and deliberate violence, coupled with his youth, that allows him to hold and use the knife and move across worlds.

This series is far closer to Chrestomanci than to Narnia in its depiction of the movement from world to world as fundamentally unnatural - in this it recalls Jones's Place Between, which "liked to have everything that did not belong sent back to the place it came from" (The Lives of Christopher Chant 27). Lyra's father, Lord Asriel, creates the bridge that she uses at the end of Northern Lights by blowing a hole in the fabric of the universe. In so doing, he reverses the magnetic poles (in a sense, literally turning the world upside-down). and wreaks havoc in the natural world. People and animals are "thrown into a panic [...] not only by the fog and the magnetic variations but by the unseasonal crackings of ice and stirrings in the soil" (The Subtle Knife 45). The knife is quieter but no less violent: the windows it opens, we slowly realize, are essentially wounds, and these wounds stay open and become infected. This becomes clear when Will cuts himself with it and severs his finger. The close association between child and world-building in these stories is made explicit when the witches try to stem his bleeding using language that conceptualizes Will's body as a world whose walls have been breached by the knife: "blood, your world is bounded," "bar the door, lock the gate" $(267,268)$. The fact that the wound will not stop bleeding, despite all the witches' efforts, speaks to the unnaturalness and severity of the breach.

This infection is also expressed in the actual world-building: Cittàgazze ("City of Magpies" in Italian) is the place where the knife was created, and each cut it makes produces a creature called a Spectre ("a little bit of the abyss that floats out and enters the world" (The Amber Spyglass 490): despair given form, if not precisely flesh. The spectres are deadly, and 
Cittàgazze is overrun with them. The only inhabitants left are those who have not yet attracted enough Dust to attract them: prepubescent children. It is important to note here how continually His Dark Materials asserts difference between adults and children. This is the same difference that gives rise to the impulse behind imagined worlds in the first place, and here it is the driving force of the plot: Cittàgazze, populated only by children who are systematically picked off as they reach adolescence, is only the most explicit reinforcement. The entire story is focused on innocence and its loss. Witness Lyra's completely instinctual and unlearned reading of the alethiometer, for example: she outstrips those who have put a lifetime of study into the same task, and she can only do it because she does not know how she does it.

The quality that makes Lyra's travels possible is her innocent and ignorant childhood, and the absorbent adaptability with which it is characterized. Among the gyptians, Ma Costa is forced to remind her that "you en't gyptian, Lyra" (Northern Lights 113); after two days at sea on her way North, "Lyra decided that this was the life for her" (166). This adaptability or malleability is crucial to Lyra's journey. Her daemon, Pantalaimon, after all, has not taken on a settled animal form; his settling on a form at the onset of Lyra's sexual maturity marks the closing of the doors between the worlds, and the end of her life as a traveller between them. The mystery of Dust in His Dark Materials, it turns out, is focused precisely on the gap between adult and child. In Mrs Coulter's words: "This is at the heart of everything, this difference between children and adults! It contains the whole mystery of Dust!" (The Subtle Knife 208).

Philip Pullman, famously, has resisted categorising His Dark Materials as children's literature, stating: "If I think of my audience at all, I think of a group that includes adults, children, male, female, old, middle-aged, young - everyone who can read. If horses, dogs, cats or pigeons could read, they'd be welcome to it as well" (Ladaga n.p.). He may be gratified that His Dark Materials has a large and strong crossover audience, but his focus on the very gap from which children's literature springs - the fraught relationship around which all 
these books cannot help but revolve - places the series squarely at the centre of the genre. Pullman must, even at the level of plot, construct childhood: it should be no surprise, at this point, that he constructs it in relation to mortality.

Lyra's journey will eventually lead her to and through the land of the dead, but even before she leaves Jordan, she confronts death in the crypts below ground with her friend Roger. Not as intimately touched by death as she will become over the course of her journey (by the death of Roger, in fact), she displays a child's somewhat callous and morbid delight in it:

"Mouldering flesh," whispered Lyra. "And worms and maggots all twisting about in their eye sockets."

"Must be ghosts down here," said Roger, shivering pleasantly. (Northern Lights 50)

This is particularly moving, given Roger's eventual fate - we meet him in The Amber Spyglass (2000) as a ghost in the land of the dead. Compare Lyra's pleased revulsion here with her empathetic embrace of the harpy No-Name ("her eye sockets [...] clotted with filthy slime, and the redness of her lips [...] caked and crusted as if she had vomited ancient blood again and again" (290)) in the last book of the trilogy: "[Lyra] reached out trembling for the harpy and put her arms around her neck, kissing and kissing her ravaged face. [...] All the words, all the confidence, all the vanity, had been shaken out of her" (The Amber Spyglass 362). If Lyra and Will are given the ability to break down the boundaries between worlds, it is so that they can break down this one, the boundary between the living and the dead. The ghosts of the netherworld, condemned to wander on an endless plain, "with as much substance as fog" (The Amber Spyglass 269) long for light and warmth and presence - for the very vitality and connection that the child Lyra represents, with "her warm throat and the strong pulse of her heart" (267). Allowed back into the world of the living (the strong intimation is that they belong there), the ghosts are able to let go of consciousness, to be drawn back from a state of non-being and absorbed into being: 
They took a few steps in the world of grass and air and silver light, and looked around, their faces transformed with joy [...] and then, as if they were made of mist or smoke, they simply drifted away, becoming part of the earth and the dew and the night breeze. (433)

It is arguable that it is her experience in the land of the dead, as much as her growing intimacy with Will, that cuts Lyra off from her own childhood. She meets her own death in that land, and having met her own death (which, characteristically for these books, is given form. if not precisely flesh), she learns that he has been her lifelong companion. He tells her:

Eventually, child, you will come to the land of the dead with no effort, no risk, a safe calm journey in the company of your own death, your special devoted friend, who's been beside you every moment of your life, and who knows you better than yourself ... (The Amber Spyglass 267)

Learning this, Lyra can no longer go forward, childlike, with an animal's intensely present vitality and heedlessness of the encroaching future. She remarks on this specifically on her return to her own world, the cuts between the universes safely sealed:

All the time I was away [...] all I thought about was the time I was in, just the present. There were plenty of times when I thought that I didn't have a future at all. And now... well, suddenly finding I've got a whole life to live, but no [...] idea what to do with it, well, it's like having the alethiometer but no idea how to read it. (517)

As it turns out, Lyra does lose the ability to read the alethiometer, she must learn how to do it again, this time through years of study instead of through innocent, ignorant, destined grace. The Oxford she returns to is the same Oxford, but different, an Oxford with its horizons expanded. Before Lyra left Jordan, she was "a healthy, thoughtless child" (Northern Lights 33), an Eve being chased away from the fruit trees. On her return she is a 
thoughtful young woman, entrusted with "her own key to the garden door" (The Amber Spyglass 519).

There has been an emphasis in all of the alternate world stories considered so far on childhood space as necessarily separate and hidden (the edges and margins and overlooked spaces are, after all, where children can escape adult authority and find space for power). Lyra and the other children in her Oxford play both above and below adult Jordan, on its roofs, and in its tunnels; Christopher Chant creeps around the corner of the mantle in his nursery to find a Place Between; Lucy only discovers Narnia by creeping into the dark and snug hiding place of Professor Kirke's wardrobe. Polly and Digory, in The Magician's Nephew, characterise the Wood Between the Worlds as an "in-between" space, space that has been coded in the story as their domain, related to the "secret base" in the attic tunnel that joins their terraced houses:

Nothing goes on in the in-between places, behind the walls and above the ceilings and under the floor, or in our own tunnel. But when you come out of our tunnel you may find yourself in any house. I think we can get out of this place into jolly well Anywhere! (The Magician's Nephew 47)

In all of these stories, childhood spaces (and the magical alternate worlds that they paradoxically contain and open out into) fit themselves into the hidden edges of the adult world.

The magical, wizarding world of J.K. Rowling's Harry Potter series (1997-2007), the last great twentieth-century alternate world fantasy, opens up precisely inside these hidden, marginal edges. The world that Harry enters after receiving the letter admitting him to Hogwarts School of Witcheraft and Wizardry has many of the characteristics of alternate worlds in this literature that are by now familiar: it is magical, and magically bigger on the inside; it frames its child hero, Harry Potter, as a saviour, and as both the subject and the object of prophecy and destiny. 
Wizarding Britain in Harry Potter and the Philosopher's Stone (1997) is heavily coded as a child's wonderland. Indeed, it is a child's storybook come to life. Perhaps the most remarkable thing about Diagon Alley and the wonders it contains is how closely it conforms to expectation: the wizards and witches wear robes and pointy hats; they purchase ingredients like dragon liver, eels eyes and bat spleens in establishments called things like "Apothecary"; there are shops containing broomsticks and cauldrons and wands, quills and parchment and the "strange silver instruments" of medieval philosophy, the precursor to modern science (Philosopher's Stone 56). People pay for these wonders, not with paper made valuable by common consensus, but with gold, silver, and bronze. This is the magic of literary trope, wondrous precisely because it is so recognisable, and recognisably magical. The series as a whole seems to delight in its own literary ancestry: Rowling samples gothic fantasy and fairy-tale freely, mining myth and legend for both grounding and inspiration.

This inventive use of literary knowledge is in service of a wish fulfilment fantasy that has its own strong literary tradition. Rowling's narrator articulates this tradition in Philosopher's Stone: "When he had been younger, Harry had dreamed and dreamed of some unknown relation coming to take him away" (34). In the end, it is not an unknown relation that rescues him, but a found family: far from being alone and friendless, Harry is chosen, protected, cherished. He gets to live in a castle, he has a pile of gold buried in an underground vault, he is a naturally gifted sports superstar, he is granted superpowers. He is a child that children dream of secretly being, not just a wizard, but the most powerful wizard of his age.

But unlike the worlds of Narnia, and Chrestomanci (and even the interpenetrating universes of His Dark Materials, which contains the child world of Cittàgazze), Rowling's wizarding world has no central waystation. Instead, it exists in secret alongside the Muggle world and squeezes into the gaps of normal reality (much like the Knight Bus that traverses the Muggle world). Wizarding Britain unfolds, TARDIS-like, from the cracks between buildings, and the spaces between train platforms (the Hogwarts Express leaves London, 
famously, from Platform 93/4); it runs through and under the England that Harry has known until then. And its entrances are marked by cramp and dust. The Leaky Cauldron, the first magical space that Harry encounters in Harry Potter and The Philosopher's Stone (1997), is also "a tiny grubby-looking pub," which "for a famous place [...] was very dark and shabby" (53). Diagon Alley, the centre of Wizarding London, is accessed by tapping a brick above a dustbin in a grotty courtyard; the Headquarters of the Order of the Phoenix in the fifth book are in a house conjured from a non-existent space in an unwelcoming square full of brokenwindowed houses where "paint was peeling from many of the doors and heaps of rubbish lay outside several sets of front steps" (Harry Potter and the Order of the Phoenix 57). Indeed, the entrance to the Ministry of Magic, the overarching authority for the Wizarding World, seems from the outside, as Harry notes himself, to be far from fitting:

The farther they walked, the smaller and less imposing the buildings became, until finally they reached a street that contained several rather shabby-looking offices, a pub, and an overflowing dumpster. Harry had expected a rather more impressive location for the Ministry of Magic.

“Here we are," said Mr. Weasley brightly, pointing at an old red telephone box, which was missing several panes of glass and stood before a heavily graffittied wall. "After you, Harry.”

He opened the telephone box door. (Harry Potter and the Order of the Phoenix 115)

It comes as no surprise, later, that there is another way into the Ministry through an out-oforder toilet cubicle. In this context, it is no accident that we first encounter Harry Potter himself for the first time not only in a very mundane house on Privet Drive ("silent and tidy under the inky sky, the very last place you would expect astonishing things to happen" (Philosopher's Stone 18)), but also in a cramped, dusty, and spider-infested cupboard under the stairs. These stories make a point of defining the childhood inside them through and against the spaces that house it, after all. It may seem odd that Dumbledore makes Harry live 
with the Dursleys, given the chronic hostility of that house, but in a universe in which the entire Wizarding World hides its startling and impressive secrets in overlooked space, folding itself into neglected corners and warding off the curious with a façade of unappealing decrepitude, Dumbledore's decision makes perfect sense. Harry Potter, the Boy Who Lived, is Dumbledore's most startling and impressive secret; the Dursleys can be relied upon to put him into a dusty cupboard and to keep him there, where he is safely overlooked.

Even inside the wizarding world, the theme of hidden and paradoxical space continues. Witches and wizards are constantly folding space: a Ford Anglia, for example, is made to hold a family of seven, a guest, and everyone's luggage. Wizarding methods of travel, especially, including Apparition, Portkey and Floo Powder, all involve the bending of space. Further, secret spaces abound at Hogwarts, as well as around it: there is the Room of Requirement, which only exists in times of need and alters its form and contents according to the circumstances of that need; there is the Chamber of Secrets, hidden at the end of the plumbing and making the question of where the drains go surprisingly interesting and pertinent; the Shrieking Shack, nestled in the heart of a Whomping Willow, is made to hide a werewolf.

It seems that along with Griswold's Scariness, Smallness, Lightness, Snugness, Aliveness (all constructed in mortal terms) another defining characteristic of the childhood space inside children's literature should be Secrecy. This secrecy goes beyond the depiction of space: Harry himself, as mentioned above, is a secret, and his role in prophecy (that he must die to defeat the villain Voldemort and save the wizarding world) is kept both from the reader, and from Harry himself for the vast majority of the series. This is done precisely in order to preserve his childlike innocence. This secrecy, too, is shaded with mortality. The resolution of the series revolves around objects that both represent and contain mortality: the seven Horcruxes, or vessels which Voldemort has invested with the broken pieces of his soul; and the three Deathly Hallows, tools that bestow a power capable of opposing him. The Hallows (the Philosopher's Stone, the Invisibility Cloak, and the Elder Wand) will bring only 
destruction on those who wield them for power. This is made clear in the very first book, Harry Potter and the Philosopher's Stone: "only one who wanted to find the Stone - find it, but not use it - would be able to get it" (217). Dumbledore knows how dangerous the Hallows are in the wrong hands, having failed to resist their temptation himself. He finally confesses to Harry:

Can you forgive me? [...] Can you forgive me for not trusting you? For not telling you? Harry, I only feared that you would fail as I had failed. I only dreaded that you would make my mistakes. (Harry Potter and the Deathly Hallows 571)

Dumbledore banks on Harry's ignorance - indeed, ensures it - in order to put Harry into a position to save the wizarding world. In this Harry is mirrored by Lucy Pevensie, stumbling unknowing through the back of a wardrobe only to be informed that she will be the Queen of a Golden Age, and Lyra Belacqua, who "must fulfil [her] destiny in ignorance of what she is doing, because only in her ignorance can we be saved" (Northern Lights 176). Harry's story, like Lyra's, is a coming of age tale; like Lyra, Harry's childhood ends in his acceptance of his own death. Harry, it is revealed, is himself a Horcrux, and he must deliberately destroy himself in order to defeat Voldemort and save the world.

Mortality shadows Harry from the first: he is an orphan, and as Patrick Ness writes in his review of The Graveyard Book, "you can't have an orphan without at least two deaths, after all" (The Guardian, n.p.). But Rowling's invented world serves to give death a physical shape, and keep it at the centre of the narrative: the magical world, for all its wonder, contains monsters. In the earlier parts of the series, this mortal danger is played for humour. The new students of Hogwarts are told on their first night in the castle, for example, to stay away from the Forbidden Forest (except, as it turns out, when they are sent in there for detention), and told to avoid the third-floor corridor if they value their lives. Hogwarts, we are told, is inhabited by ghosts, but they are harmless and friendly. The overall effect of this humour is a kind of normalisation: it underscores not how dangerous the Wizarding World is, but rather how hardy witches and wizards are. People who fall off high places and bounce 
(like Neville Longbottom, who is, at least on first meeting, one of the least powerful wizards we encounter in the books) are very hard to kill. But as the series progresses, this hardiness turns on itself and actually increases the sense of jeopardy. Given how very hard it is to kill a wizard, the killer who manages it must be terrible indeed. And Voldemort is, indeed, terrible.

His shadow lengthens over the world of the series, almost literally. In the first two books (Philosopher's Stone and Chamber of Secrets), Wizarding Britain is a riot of colour. The blue sky, brilliant robes, bright paint, shiny windows and liveliness of Diagon Alley provides a strong contrast with what Harry's life would have been had he never got his letter; he would have gone to school at Stonewall High wearing Dudley's hand-me-downs, dyed grey. But darkness enters, both literally and metaphorically, in the form of the Dementors in Harry Potter and the Prisoner of Azkaban. After the Second Wizarding War has begun in Harry Potter and the Half-Blood Prince, Diagon Alley is a vastly darker place:

Diagon Alley had changed. The colourful, glittering window displays of spellbooks, potion ingredients, and cauldrons were lost to view, hidden behind the large Ministry of Magic posters that had been pasted over them. [...] A few windows were boarded up, including those of Florean Fortescue's Ice Cream Parlour. (HalfBlood Prince 108)

The last three books of the series are, even by the standards of children's literature and its ever-present insistence on loss, an almost unrelenting bloodbath. The Great Hall at Hogwarts, a place of warmth and community throughout the series, is, after the Battle of Hogwarts in Deathly Hallows, filled with corpses.

The enduring impact of the Harry Potter series can be put down to the way it combines and synthesises so many different facets of twentieth-century children's fantasy. There are elements in the books of time fantasy (think of Hermione's time-turner in Harry Potter and the Prisoner of Azkaban, or of Dumbledore's Pensieve in Harry Potter in the Goblet of Fire, in which thought and memory are made present); of the animal story (in the Animagi); and of the ghost story in the ghosts of Hogwarts Castle, and also, less literally, in 
the ghosts of James and Lily Potter, embodied in Harry himself. We are told more than once that Harry looks just like his father, that he has his mother's eyes. Harry is haunted; he is an object of legacy as well as of prophecy. It is possible, further, to argue that the entire series is a form of ghost story: that Harry is a dead boy walking from the moment that Voldemort, however inadvertently, makes him a Horcrux. Harry's slow progress into the Forbidden Forest to face Voldemort (and his own death) at the end of Deathly Hallows is, in this reading, only the last few metres of a journey that started on a flying motorbike in Philosopher's Stone. The narrative, closely aligned with Harry's viewpoint, notes the terrible deliberateness of this march:

If he could only have died like Hedwig, so quickly he would not have known it had happened! Or if he could have launched himself in front of a wand to save someone he loved [...]. This cold-blooded walk to his own destruction would require a different kind of bravery. (Deathly Hallows 554-5)

The narrative takes pains to dwell on the fact that it is precisely Harry's knowledge of his impending death that gives him the clearest sense he ever has of being alive:

why had he never appreciated what a miracle he was, brain and nerve and bounding heart? [...] His heart was leaping against his ribs like a frantic bird. Perhaps it knew it had little time left, perhaps it was determined to fulfil a lifetime's beats before the end. (555-6)

Here, Rowling makes explicit the quality that is at the root of the mortality in the literary child figure and in children's literature more generally: the quality of intense, and fleeting, vitality, a vitality that makes the prospect of mortality that much starker. Explicit, too, is the identification drawn between the end of childhood and the end of life altogether. Harry's death and his return from death frame his adulthood (in the epilogue of Deathly Hallows) as an afterlife. We have seen this direct articulation before, in Narnia: the train crash at the end of The Last Battle is presented (however ambivalently to the secular reader) as an occasion of joy: 
Lucy said, "We're so afraid of being sent away, Aslan. And you have sent us back into our own world so often."

"No fear of that," said Aslan. "Have you not guessed?"

Their hearts leaped, and a wild hope rose within them. (The Last Battle 165)

Alternate world stories, and also children's fantasy more generally, rest on the conception of childhood as a space apart, and treat childhood as an end in itself, valuable in its difference from adulthood. This literature necessarily observes that childhood from a distance in space and time, and constructs it from memory of what was, description (from a distance) of what is, and anticipation of what will be. Little wonder, in these circumstances, that the end of childhood in this literature amounts to a death, little wonder that it is shaded with a larger and more permanent form of passing away. But this sense of an ending functions, as always, to join instead of separate; it serves to collapse the difference between adult and child, and erase the distance between them. This conception stretches back, as has been said, far beyond the happy death of Narnia to the Elsewheres of Victorian children's fantasy, which, like Harry Potter and Narnia, explicitly frame death as more life, and align "more life" with adulthood. The literary child is always once and future, even in its vital present tense, and conceiving of this unique temporal placement in mortal terms makes a larger point about the productive distance between adult and child in children's literature, and about the childhood that distance (and its bridging) cannot help but construct: it has always already ended, it is always ending, and always not yet. 


\section{Coda}

\section{Fantasy and Mortality: The Ocean at the End of the Lane}

Death happens to all of us

Neil Gaiman, Ocean at the End of the Lane

In lieu of a formal conclusion, I would like, in a thesis of close readings, to close with a coda. This coda will, through the reading of an exemplary text, bring together the various mortal motifs that the different chapters of the thesis have explored and examined, and in their unification, demonstrate how fundamental a contemplation of mortality is to fantasies of childhood.

This text is Neil Gaiman's The Ocean at the End of the Lane (2013). It should be said, firstly, that The Ocean at the End of the Lane is not (or not precisely) a children's text: it was written for, and marketed to, an adult readership. But this adult novel - a tale in which an adult man makes sense of himself and his adulthood by exploring the recent past of childhood memory - is also, at base, a novel of childhood. This thesis has argued throughout that the focus on mortality in children's literature is an inevitable (and productive) consequence of the gap between adult and child at its centre; that when the adult writes childhood, the gap between adult and child determines the nature and shape of the work, and turns it deathwise. This same gap determines the nature and shape of Ocean and the End of the Lane. It is telling that in a fictional exploration (in form and theme) of the relation between adulthood and childhood, Gaiman is impelled to use the mechanisms of children's fantasy: to set childhood apart as a time of magic; to construct that child according to its imaginative alignments as animal, as toy, as ghost; to twist and manipulate the time and space the child inhabits to reflect the endless and fleeting qualities of childhood. The novel 
constructs the child, in short, as a beginning, as an ending, and as the beginning of an ending.

Children's fantasy tends to divide itself generically despite its fundamental unities: the animal story is different from the toy story, which is different again from the ghost story, and so on: each genre has its own particular concerns and priorities, and each, as this thesis has shown, has its own particular inflection on the mortality that is intrinsic to all of them. The Ocean at the End of the Lane, as an adult text that contains within its framing story a fantasy of childhood, unites these genres in a way that children's fantasy itself does not tend to. We find, in its pages, the intensely present and threatened vitality of the animal, the enduring and remembering power of the toy, and the haunting, memorialised quality of the ghost. Time and physical space are warped around the book's seven-year-old protagonist in ways that construct his childhood as a magical space, a space of fantasy. Most crucially, however, Ocean at the End of the Lane is notable in the narrative's consciousness of and open commentary on its own workings. The framing story (the story that holds the fantastic tale of the seven-year-old protagonist inside it) depicts the seven-year-old protagonist as a middle-aged man. He returns to his childhood haunts; once there, he tells the story of his own long-ago child-self in the first-person: the contained tale is an explicit and deliberate act of memory. The narrator comments on his tale as it unfolds, musing openly on the workings of memory, on the peculiarities and distortions of retrospectivity, on the respective natures of childhood and of adulthood, and on how intimately and intrinsically his own seven-yearold identity as a solitary, bookish child was informed and inflected by the childhoods he read about in children's books. His childhood tale is constructed, as will by now be no surprise, in mortal terms.

The middle-aged narrator, to begin with, is drawn back to his childhood home and its environs by bereavement. He has attended a funeral (it is not specified whose, but it is strongly implied to be his father's), and he is wearing funeral clothes: 
I wore a black suit and a white shirt, a black tie and black shoes, all polished and shiny: clothes that normally would make me feel uncomfortable, as if I were in a stolen uniform, or pretending to be an adult. Today they gave me comfort, of a kind. (Ocean at the End of the Lane 3)

From the first, then, death and bereavement are linked to conceptions of childhood, and adulthood, and to the shifting and sometimes uncertain boundary between them. The narrator has been driving around, avoiding the wake. "It was time," he says, "to drive to my sister's bustling, cheerful house, all tidied and stiff for the day. I would talk to people whose existence I had forgotten years before [...]. We would talk about the departed; we would remember the dead" (4-5). He misses that wake entirely, as it turns out; instead, he spends the afternoon by the pond behind the Hempstock farm, lost in childhood memory ("[i]t had become dusk, without my noticing, while I had been sitting there" (235)). But a wake is held all the same: in visiting the Hempstocks, and in remembering and recounting his memory of his seven-year-old self, and of his life-altering friendship with Lettie Hempstock, the elevenyear-old granddaughter of the house, herself long-gone, the narrator does talk to people whose existence he had forgotten years before; he talks about the departed, he remembers the dead.

The narrator's childhood memories, too, begin with death. His parents' lodger (known as "the opal miner" - indeed, only the Hempstocks, the monster, Ursula Monkton, and, oddly enough, the cats, Fluffy, Monster, and Ocean, are given proper names in the story) runs over the boy's beloved kitten (Fluffy) upon his arrival. According to the miner, there is no cause for upset, because he has bought the boy a new cat, a huge feral tomcat named Monster. This episode is the first demonstration in the book of the gulf that the boy feels (whether or not it actually exists) between himself and the adults around him: "I knew you could not simply replace something alive," the narrator tells us, "but I dared not grumble to my parents about it. They would have been baffled at my upset: after all, if my kitten had been killed, it had also been replaced. The damage had been made up" (15-16). But the 
kitten's death is notable too, in its foreshadowing of the story to come: the miner himself will die, by suicide, in the back seat of the family car; his death is the first in a chain of events which will introduce the boy to the Hempstocks, and lead, eventually, to an invasion of the boy's home by a monster.

The body of the miner is described, in detail, from the boy's perspective, using the only perspective he has to offer as a seven-year-old: a visit to the Chamber of Horrors in Madame Tussaud's Waxwork Museum. The waxworks there were not convincing. The narrator tells us: "They could not look dead because they did not ever look alive" (23). "The thing in the back seat," he continues, "was not convincing either" (23). The boy's visit to Madame Tussaud's is formative: the boy, at six, "had wanted to thrill to waxworks of Dracula and Frankenstein's Monster and the Wolf-man" (22). Instead, there is a parade of "unremarkable, glum-looking men and women who had murdered people - usually lodgers, and members of their own families" (23). The boy is terribly frightened, but not so much by the waxworks themselves as by the spectre of anatomy:

The plaques that explained who [the dead] were also told me the majority of them had murdered their families and sold the bodies to anatomy. It was then that the word anatomy garnered its own edge of horror for me. I did not know what anatomy was. I only knew that anatomy made people kill their children. (23)

This is another kind of foreshadowing. After the boy tumbles into the magical orbit of the Hempstocks, he manages, by misadventure, to become the conduit into this world of a flea, an interloping monster, who takes the form of an attractive adult woman named Ursula Monkton ("She had shortish honey-blond hair, huge grey-blue eyes, and pale lipstick" (72)). She invades the boy's house by becoming their housekeeper, and by seducing the boy's father: under her sway, the boy's father tries to kill the boy by drowning him in the bathtub. This attempted murder is described in terms that evoke childish bafflement: "I was horrified, but it was initially the horror of something happening against the established order of things. I was fully dressed. That was wrong. I had my sandals on. That was wrong. The bath water 
was cold, so cold and so wrong" (97). This bafflement is echoed in the boy's description of another scene shortly after his struggle in the bathroom:

I was not sure what I was looking at. My father had Ursula Monkton pressed up against the side of the big fireplace in the far wall. He had his back to me. She did too, her hands pressed against the huge, high mantelpiece. He was hugging her from behind. Her midi skirt was hiked up around her waist. (105)

Anatomy, Ursula Monkton attempts to prove, does indeed make people kill their children, and the boy's misgivings at the Chamber of Horrors are borne out.

Ursula Monkton is a being from another world, or another plane of existence, come over from "the old country" with the Hempstocks (maiden, mother, crone) and their farm: "Hempstock Farm stretches a very long way," Lettie tells the boy. "We brought a lot of this with us from the old country, when we came here. The farm came with us, and brought things with it when it came. Gran calls them fleas" (55). The Ocean at the End of the Lane is a species of alternate world fantasy in this way, and the danger Ursula Monkton poses is similar to that of the spectres in Philip Pullman's His Dark Materials trilogy: she upends the natural order of things by being in the wrong place, being a pest. She is not a spectre, however, but a flea. The real spectres in this story are the hunger birds: "grey-black, naked, winged but featherless; faces from nightmares - beak-like snouts filled with needle-sharp teeth, made for rending and tearing and devouring, and hungry red eyes" (173). These creatures are the cleaners and keepers of the boundaries between worlds, who fall upon Ursula Monkton and eat her for having trespassed, for being somewhere she does not belong. But the boy is also in danger from them: the door through which Ursula Monkton made her way into this world is in his heart. He is killed ("The hunger birds tore out your heart. You screamed so piteously as you died," Ginnie Hempstock tells him (238)), and Lettie sacrifices herself to save him ("She couldn't abide that. She had to do something").

Lettie is not precisely dead, however, being a Hempstock. Instead she is taken in by the duckpond that is also an ocean at the back of the Hempstock farmhouse, and sleeps to 
heal. The boy, now a middle-aged man, is called back to the Hempstock farm, both in the name of healing his own wounds, and so that Lettie can see what he has made of himself. Ginnie Hempstock, the mother of the house, tells him that "Lettie just wants to know if it was worth it" (238). It is the fantasy setting of the book that allows Gaiman this kind of manipulation of life and death, which he uses to disconcerting effect. Fantasy also allows him to manipulate time: his construction of childhood (the question of what it is to be a child) is underscored by this manipulation. Lettie, despite her appearance, is not a little girl:

"Once you've been around for a bit, you get to know stuff."

I kicked a stone. "By 'a bit', do you mean 'a really long time'?"

She nodded.

"How old are you, really?" I asked.

"Eleven."

I thought for a while. Then I asked, "How long have you been eleven for?" She smiled at me. (40-1)

And Ursula Monkton, for all that she wields the power (including the sexual power) of an adult woman, is childlike:

"I'm not going now," said Ursula Monkton, and she sounded petulant, like a very small child who wanted something. "I've only just got here. I have a house, now. I have pets - his father is just the sweetest thing." (159)

Facing her own end, the boy observes that Ursula Monkton "had mud on her face, and on her knees, and she was wailing" (168). The interactions between Lettie and Ursula Monkton twist and subvert the inevitable power imbalance in the adult-child relation, even if this is beyond the comprehension of the average seven-year-old boy who looks on:

Lettie was just a girl, even if she was a big girl, even if she was eleven, even if she had been eleven for a very long time. Ursula Monkton was an adult. It did not matter, at that moment, that she was every monster, every witch, every nightmare 
made flesh. She was also an adult, and when adults fight children, adults always win. (116)

But Lettie does defeat Ursula Monkton, and she goes on to defeat death. The power both she and the boy wield is intimately linked to their childhood. They pen Ursula Monkton in, for example, and lead her to her doom with a trail of breadcrumbs that is also a set of broken and abandoned toys (objects, that is, in which childhood is invested). They use:

A clear glass marble with a twist of green inside it; one of the little metal objects we call knucklebones; a bead; a pair of bright blue doll's eyes, connected at the back with white plastic, to make them open or close; a small horseshoe magnet, a black pebble, a badge, the kind that came attached to birthday cards, with I Am Seven on it; a book of matches; a plastic ladybird with a black magnet in the base; a toy car, half-squashed, its wheels gone; and last of all, a lead soldier. It was missing a leg. (157)

Strength is found, too, in the animal instinct that is also associated with childhood. When his father, under the spell of Ursula Monkton, pushes the boy under the water in the bath ("I had no doubt," the narrator says, "that I was going to die there" (97)), he saves himself with the desperation of the animal at bay. Seeing his father's maroon paisley tie dangling towards him through the water, he latches on with claws and teeth: "Now he pushed me down again, but fear of death gives us strength: my hands and my teeth were clamped to his tie, and he could not break my grip ..." (98). It is fantasy - the otherworldliness of the story and its characters, even as the action takes place around the boy's own house in his real world - that permits both mortal peril and its (childish) subversion in the book. Fantasy here amplifies the cultural forces at work in childhood and its cultural construction more generally, and elevates them to the level of plot. Questions of age, power, and mortality - of what childhood is, and how it is - are thus thrown into sharp relief. 
Fantasy also serves to set childhood apart in the story, to separate the narrator, forty years in the future, from the boy he once was. This construction is "a testament," as the editors of Space and Place in Children's Literature write, "to the way in which childhood itself is often seen as a world apart, with its own logic and landmarks that distinguish it from adult reality" ("Introduction: Spaces of Power, Places of Play" 1). In Ocean at the End of the Lane, this sense of a space apart is insisted upon. After Lettie dies and is taken into the ocean, Ginnie and Old Mrs Hempstock take away the boy's memories. His mother is told that he has been at Lettie's going-away party, and that she is off to live with her father in Australia: this quietly becomes the boy's new reality. "The party had been fun," he says, "although I couldn't remember much about it. [...] A small part of my mind remembered an alternative pattern of events, and then lost it, as if I had woken up from a comfortable sleep, and then [...] returned to my dream" (230). His childhood home is destroyed ("The house was demolished after we moved out. I would not go and see it standing empty, and refused to witness the demolition. There was too much of my life bound up in those bricks and tiles, those drainpipes and walls" (231-2)), and the narrator's severance from the boy he was is almost total. This forgetting holds until he returns to "the Hempstock land where the barriers between life and death were thin" (207). In that place, with its permeable borders (between life and death, and, by close alignment, adulthood and childhood) the narrator can once again know his boyhood self.

Confronted with memory, haunted by its absence, and then by its presence, the narrator is compelled to share it, to relive his past, and attempt to make sense of its relation to the man he has become. This might be the root of the narrator's impulse, displayed throughout the story, to examine the rupture between his child-self, and the baffling adults that surrounded him: "Adult stories never made sense," he tells us. "They made me feel like there were secrets, masonic, mythic secrets, to adulthood" (71). His sense of confusing distance, of divide, makes itself known in subjects as mundane as peas: "Peas baffled me. I could not understand why grown-ups would take things that tasted so good raw, and put them in tins, and make them revolting" (155). The childhood he reconstructs out of imprecise 
and questionable memory ("Didn't I just say you'll never get any two people to remember anything the same?" Old Mrs Hempstock sniffs (238)) is the childhood of storybooks, both in its terrors, and in its joys. This is more than appropriate for a child who, by his own admission, "lived in books more than [he] lived anywhere else" (10):

Growing up, I took so many cues from books. They taught me most of what I knew about what people did, about how to behave. They were my teachers and my advisers. In books, boys climbed trees, so I climbed trees, sometimes very high, always scared of falling. In books, people climbed up and down drainpipes to get in and out of houses, so I climbed up and down drainpipes too. (103)

The childhood he performs and enacts from the stories he reads finds an ideal setting in rambling and sprawling gardens, fields, lanes, and kitchens, both the ideal "Good Place" of the Hempstocks with its Blytonesque feasts ("For dessert, we had the pie, stuffed with apples and with swollen raisins and crushed nuts, all topped with a thick yellow custard, creamier and richer than anything I had ever tasted ..." (126)), and the compromised kitchen of his own home, infected by Ursula Monkton ("I was determined not to eat anything she had made or cooked or touched" (92)). For all of the terror that upends and interrupts the boy's life over the course of the story, there remains the strong sense of a lost kingdom: "I loved the house, and the garden. I loved the rambling shabbiness of it. I loved the place as if it were a part of me, and perhaps in some ways it was" (78). In the present-day of the middle-aged narrator, this playground is lost ("the ramshackle world I lived in was demolished and replaced by trim, squat, regular houses" (233), and he can never come there again: his recollection is framed by mourning.

While all of this strikes at the heart of the impulse that drives children's fantasy (as The Ocean at the End of the Lane demonstrates structurally, as well as thematically), Gaiman's fantasy of childhood also, as it cannot help but do, asserts connection. The child of seven, for all of his distance from the man who remembers him, is continuous with that man: the workings of memory serve to make the past present, to join the long ago to the present 
day. The rupture, so dwelled upon by the narrative, is also healed by it: having told his tale, and reached the end of "the endless summer evening" (238), the narrator asks whether Lettie's sacrifice to save him was worth it. Ginnie Hempstock reassures him: "You don't pass or fail at being a person, dear. [...] I think you're doing better than you were the last time we saw you. You're growing a new heart, for a start" (239).

As the discussion contained both here and in the previous chapters has demonstrated, reading fantasy for children as a series of intimations of mortality is both seductive and encompassing. Mortality, in this reading, accounts for the various and paradoxical ways that the literary child is constructed and represented in fantasies of childhood, in relation to the animal, the toy, and the ghost, and in relation to fantasy's manipulations of time and space. The fact that mortal intimations are so clear and present over all of these different subgenres reveals their intrinsic, structural role in children's fantasy: the contemplation of mortality, here, is more than a theme. As the inevitable product of adulthood's relation to childhood - the very relation that engenders children's literature, and sets it apart from other genres - mortality works to explain this literature, to determine its shape and function. Indeed, upon recognising mortality as a definitive presence - that childhood in this literature is always constructed in terms of its ending, that adulthood is positioned in relation to that ending, and that both appear in relation to the larger ending that mortality represents - it is hard to conceive of children's fantasy in any other way. 


\section{Works Cited}

“Animal, N.” OED Online, Oxford UP, Nov. 2010, http://www.oed.com/view/Entry/273779

“Animism, n.” OED Online, Oxford UP, Nov. 2010, http://www.oed.com/view/Entry/7793.

Adderley, C. M. “The Best Thing For Being Sad: Education and Educator's in TH White's The Once and Future King." Quondam et Futurus, vol. 2, no. 1, Spring 1992, pp. 55-68.

Ariès, Philippe. Centuries of Childhood. Translated by Robert Baldick, Cape, 1962.

Arnold, Matthew. “Stanzas from the Grande Chartreuse.” The Poetical Works of Matthew Arnold, edited by C.B. Tinker and H.F. Lowry, Oxford UP, 1950, pp. 299-306.

Auerbach, Nina. Romantic Imprisonment: Women and Other Glorified Outcasts. Columbia UP, 1985 .

Auden, W. H. “Lullaby.” 1937. Collected Poems, edited by Edward Mendelson, Vintage, 1991, pp. $157-58$.

Austin, Linda M. “'Children of Childhood': Nostalgia and the Romantic Legacy.” Studies in Romanticism, vol. 42, no. 1, 2003, pp. 75-98.

Bachelard, Gaston. The Poetics of Space. 1957. Translated by Maria Jolas, Beacon, 1958.

Barrie, J. M. Peter and Wendy. 1911. Edited by Anne Hiebert Alton, Broadview, 2011.

Beauvais, Clémentine. The Mighty Child: Time and Power in Children's Literature. John Benjamins, 2015.

Boston, L. M. An Enemy at Green Knowe. 1964.

---. The Children of Green Knowe. Puffin, 1954.

---. The Chimneys of Green Knowe. 1958. Puffin, 1976.

---. The River at Green Knowe. Faber and Faber, 1959. 
---. The Stones of Green Knowe. 1976. Harcourt Young Classic, 2005.

Briggs, Julia. Night Visitors: The Rise and Fall of the English Ghost Story. Faber, 1977.

Brontë, Charlotte. Jane Eyre. 1847. Oxford UP, 2000.

Butler, Catherine. “Children's Literature: Ideologies of the Past, Present and Future.” The History of British Women's Writing, 1945 - 1975, edited by Clare Hanson and Susan Watkins, Palgrave Macmillan, 2017, pp. 259-72.

---. Four British Fantasists: Place and Culture in the Children's Fantasies of Penelope Lively, Alan Garner, Diana Wynne Jones, and Susan Cooper. Scarecrow, 2006.

Campbell, Gordon. "Neil Gaiman’s Brand of Horror is Aimed at Parents, as Much as Kids.” Werewolf, 3 Aug. 2011, werewolf.co.nz/2011/o8/classics-the-graveyard-book-2009/. Accessed 2 Feb 2015.

Carlyle, Thomas. Characteristics. 1831. Boston, 1877.

Carpenter, Humphrey. "Excessively Impertinent Bunnies: The Subversive Element in Beatrix Potter." Children and Their Books: A Celebration of the Work of Iona and Peter Opie, edited by Gillian Avery and Julia Briggs, Clarendon, 1989, pp. 271-298.

---. Secret Gardens: A Study of the Golden Age of Children's Literature. Allen \& Unwin, 1985. Carroll, Lewis. Alice's Adventures in Wonderland, and Through the Looking Glass, and What Alice Found There. 1865/1871. Edited by Peter Hunt, Oxford UP, 2009.

Chabon, Michael. "Dust \& Daemons.” The New York Review of Books, March 25, 2004, http://www.nybooks.com/articles/2004/o3/25/dust-daemons. Accessed 25 Apr. 2017. Chambers, Aidan. "The Reader in the Book.” Booktalk: Occasional Writing on Literature and Children, Bodley Head, 1985, pp. 34-58. 
Cosslett, Tess. Talking Animals in British Children's Fiction, 1786-1914. Ashgate, 2006.

Coveney, Peter. The Image of Childhood. 1957. Revised Edition, Penguin, 1967.

Danahay, Martin A. "Nature Red in Hoof and Paw: Domestic Animals and Violence in Victorian Art.” Victorian Animal Dreams: Representations of Animals in Victorian Literature and Culture, edited by Deborah Denenholz Morse and Martin A Danahay, Ashgate, 2007, pp. 97119.

Darton, F. J. Harvey. Children's Books in England: Five Centuries of Social Life. Cambridge UP, 1932.

DeLaura, David. “The Allegory of Life: The Autobiographical Impulse in Victorian Prose.” Approaches to Victorian Biography, edited by George Landow, Ohio UP, 1979, pp. 333-354.

Empson, William. Some Versions of Pastoral: A Study of the Pastoral Form in Literature, 1935, Penguin, 1966.

Farmer, Penelope. Charlotte Sometimes. Random House, 1969.

Gaiman, Neil. The Graveyard Book. Bloomsbury, 2008.

---. The Ocean at the End of the Lane. Headline, 2013.

---. The Tragical Comedy or Comical Tragedy of Mr Punch: A Romance. DC Comics, 1994.

Gardner, Martin. The Annotated Alice. Clarkson N. Potter, 1960.

Gilead, Sarah. "Magic Abjured: Closure in Children’s Fantasy Fiction.” PMLA, vol. 106, no. 2, Mar. 1991, pp. 277-93.

Gilmour, Robin. The Novel in the Victorian Age: A Modern Introduction. Edward Arnold, 1986. Godden, Rumer. "Impunity Jane: The Story of a Pocket Doll." The Fairy Doll and Other Tales from the Dolls' House, Macmillan, 2012, p. 447-468 
---. “The Doll's House.” The Fairy Doll and Other Tales from the Dolls' House, Macmillan, 2012, p. $1-127$

---. “The Mousewife.” Mouse Time, Macmillan, 1995, pp. 7-29.

Gosse, Edmund. Father and Son: A Study of Two Temperaments. 1907. Penguin, 1989.

Graham, Daniel W. "Heraclitus.” The Stanford Encyclopedia of Philosophy, Fall 2015 Edition, https://plato.stanford.edu/archives/fall2015/entries/heraclitus. Accessed 23 Apr. 2017.

Green, Roger Lancelyn. “The Golden Age of Children's Books.” Only Connect: Readings on Children's Literature, edited by Sheila Egoff et al., 2nd ed., Oxford UP, 1980, pp. 1-16. Griswold, Jerry. Feeling Like a Kid: Childhood and Children's Literature. John Hopkins UP, 2006.

Grylls, David. Guardians and Angels: Parents and Children in Nineteenth-Century Literature. Faber \& Faber, 1978.

Gubar, Marah. Artful Dodgers: Reconceiving the Golden Age of Children's Literature. Oxford UP, 2009.

Hoban, Russell. The Mouse and His Child. Faber and Faber, 1969.

Hale, Elizabeth. "Truth and Claw: The Beastly Children and Childlike Beasts of Saki, Beatrrix Potter, and Kenneth Grahame." Childhood in Edwardian Fiction: Worlds Enough and Time, edited by Adrienne E. Gavin and Andrew F. Humphries, Palgrave Macmillan, 2009, pp. 191207.

Hall, Linda. “'House and Garden': The Time-Slip Story in the Aftermath of the Second World War." The Presence of the Past in Children's Literature, edited by Ann Lawson Lucas, Praeger, 2003, pp. 153-58. 
Hollindale, Peter. "Aesop in the Shadows.” Children's Literature: Classic Texts and

Contemporary Trends, Palgrave Macmillan, 2009, pp. 96-99.

---. Signs of Childness in Children’s Books. Thimble, 1997.

---. “Timescape at Hemingford Grey: Lucy Boston’s Centenary.” Children’s Literature, vol. 22, 1994, pp. 139-148.

Hunt, Peter. “The Same But Different: Conservatism and Revolution in Children's Fiction.”

Children's Literature: Approaches and Territories, edited by Janet Maybin and Nicola J. Watson, Palgrave Macmillan, 2009, pp. 70-84.

---. “Unstable Metaphors: Symbolic Spaces and Specific Places.” Space and Place in Children's Literature, 1789 to the Present, edited by Maria Sachiko Cecire et al., Ashgate, 2016, pp. 2337.

Inglis, Fred. The Promise of Happiness: Value and Meaning in Children's Fiction. Cambridge UP, 1981.

Iser, Wolfgang. The Implied Reader: Patterns of Communication from Bunyan to Beckett. John Hopkins UP, 1974.

Jackson, Anna. “Uncanny Hauntings, Canny Children.” The Gothic in Children’s Literature:

Haunting the Borders, edited by Anna Jackson et al., Routledge, 2008, pp. 157-176.

Jackson, Anna, et al., editors. "Introduction." The Gothic in Children's Literature: Haunting the Borders, Routledge, 2008, pp. 1-14.

Johnstone, Rosemary Ross. “Childhood: A Narrative Chronotope.” Children’s Literature: Critical Concepts in Literary and Cultural Studies, edited by Peter Hunt, vol. 3: Cultural Contexts, Routledge, 2006, pp. 46-67. 
Jones, Diana Wynne. Charmed Life. 1977. HarperCollins, 2000.

---. “Inventing the Middle Ages.” Reflections: On the Magic of Writing, Greenwillow, 2012, pp. 196-210.

---. The Lives of Christopher Chant: The Childhood of Chrestomanci. Methuen, 1988.

Keats, John. “Ode to a Nightingale.” Complete Poetry and Selected Prose of Keats, edited by Harold Edgar Briggs, The Modern Library, 1967, pp. 290-93.

Kelly, Richard. “Introduction.” The Water Babies, by Charles Kingsley, edited by Richard Kelly, Broadview, 2008, pp. 9-32.

Killeen, Jarlath. History of the Gothic: Gothic Literature 1825-1914. U of Wales P, 2009.

Kincaid, James. Child Loving: The Erotic Child and Victorian Culture. Routledge, 1992.

---. "Dickens and the Construction of the Child." Dickens and the Children of Empire, edited by Wendy S. Jacobson, Palgrave, 2000, pp. 29-42.

King-Smith, Dick. Lady Daisy. Viking, 1992.

Kingsley, Charles. The Water Babies. 1863. Edited by Richard Kelly, Broadview, 2008.

Kingsley, Mary Lucas, editor. Charles Kingsley: His Letters and Memories of His Life. 9th ed., vol. I, London, 1877.

Kipling, Rudyard. The Jungle Book. 1893. Macmillan, 1932.

---. The Second Jungle Book. 1895. Macmillan, 1983.

Knoepflmacher, U.C. Ventures into Childland: Victorians, Fairy Tales and Femininity. U of Chicago P, 1998.

Krips, Valerie. The Presence of the Past: Memory, Heritage and Childhood in Children's Literature. Garland, 2000. 
Kutzer, Daphne M. “A Wildness Inside: Domestic Space in the Work of Beatrix Potter.” The Lion and the Unicorn, vol. 21, no. 2, Apr. 1997, pp. 204-214.

Kuznets, Lois R. When Toys Come Alive: Narratives of Animation, Metamorphosis, and Development. Yale UP, 1994.

Ladaga, Lili. "Philip Pullman weaves spell with 'His Dark Materials."' CNN.com, November 10, 2000, http://edition.cnn.com/200o/books/news/11/10/philip.pullman. Accessed 2 June 2017.

Leach, Karoline. In the Shadow of the Dreamchild: A New Understanding of Lewis Carroll. Peter Owen, 1999.

Leavis, Q. D. “The Water Babies.” Children's Literature in Education, vol. 7, no. 4, 1976, pp. 155163.

Lenz, Millicent. "Russell Hoban's The Mouse and His Child and the Search to Be Self-Winding." Children’s Literature Association Quarterly, Proceedings 1978, pp. 64-69.

Lesnik-Oberstein, Karín. “Childhood and Textuality: Culture, History, Literature.” Children in Culture: Approaches to Childhood, edited by Karín Lesnik-Oberstein, Palgrave Macmillan, 1998, pp. 1-29.

---. “Defining Children's Literature and Childhood.” International Companion Encyclopedia of Children's Literature, edited by Peter Hunt, Routledge, 1996, pp. 17-31.

Lewis, C. S. Prince Caspian. 1951. Collins, 2001.

---. The Horse and His Boy. 1954. Collins, 1971.

---. The Last Battle. 1956. Puffin, 1964.

---. The Lion, the Witch and the Wardrobe. 1950. Fontana Lions, 1980. 
---. The Magician's Nephew. 1955. HarperCollins, 2001.

---. The Silver Chair. 1953. HarperCollins, 2005.

---. The Voyage of the Dawn Treader. 1952. Grafton, 2002.

Lively, Penelope. A Stitch in Time. 1976. HarperCollins, 2011.

---."Bones in the Sand.” Innocence and Experience: Essays and Conversations on Children's Literature, edited by Barbara Harrison and Gregory Maguire, Lothrop, Lee and Shepard, 1987, pp. 13-21.

---. The Ghost of Thomas Kempe. Puffin, 1973.

Locke, John. Some Thoughts Concerning Education. 1693. 9th ed., London, 1732.

Lovell-Smith, Rose. “The Animals of Wonderland: Tenniel as Carroll's Reader.” Criticism, vol. 45, no. 4, Fall 2003, pp. 383-415.

Lurie, Alison. Don't Tell the Grown-Ups: Subversive Children's Literature. Little, Brown \& Co, 1990.

MacDonald, George. A Dish of Orts. 1893. Gutenberg, 2005, http://www.gutenberg.org/files/9393/9393-h/9393-h.htm.

---. At the Back of the North Wind. 1871. Edited by Roderick McGillis and John Pennington, Broadview, 2011.

---. The Golden Key. 1867. Gutenberg, 2007, http://gutenberg.net.au/ebooks07/o700571h.html. Manhire, Bill. “Children.” Collected Poems, Victoria UP, 2001, pp. 120-21.

Manlove, C. N. "MacDonald and Kingsley: A Victorian Contrast." The Gold Thread: Essays on George MacDonald, edited by William Reaper, Edinburgh UP, 1990, pp. 140-162. ---. Modern Fantasy: Five Studies. Cambridge UP, 1975. 
Marinelli, Peter V. Pastoral. Methuen, 1971.

McCulloch, Fiona. The Fictional Role of Childhood in Victorian and Early Twentieth-Century Children's Literature. Edwin Mellen, 2004.

McGavran, James Holt, editor. Literature and the Child: Romantic Continuations, Postmodern Contestations. U of Iowa P, 1999.

---, editor. Romanticism and Children's Literature in Nineteenth-Century England. U of Georgia $\mathrm{P}, 1991$.

Miller, Laura. The Magician's Book: A Skeptic’s Adventures in Narnia. Little, Brown \& Co, 2008. Milne, A. A. The House at Pooh Corner. Methuen, 1928.

---. Winnie-The-Pooh. Methuen, 1926.

Milton, John. Paradise Lost. 1667. Edited by Alistair Fowler, Longman, 1971.

Moore, John David. "Pottering about in the Garden: Kenneth Grahame’s Version of Pastoral in The Wind in the Willows.” Journal of the Midwest Modern Language Association, vol. 23, no. 1, Spring 1990, pp. 45-60.

Morris, Tim. You're Only Young Twice: Children's Literature and Fïlm. U of Illinois P, 2000. Myers, Mitzi. "Reading Children and Homeopathic Romanticism: Paradigm Lost, Revisionary Gleam or 'Plus Ça Change, Plus C'est la Meme Chose'?” Literature and the Child: Romantic Continuations, Postmodern Contestations, edited by James Holt McGavran, U of Iowa P, 1999.

Ness, Patrick. "Ghost Stories." The Guardian, 25 October 2008. https://www.theguardian.com/books/2008/oct/25/booksforchildrenandteenagersneilgaiman. Accessed 29 May 2017. 
Nikolajeva, Maria. From Mythic to Linear: Time in Children's Literature. Scarecrow, 2000.

---. Power, Voice and Subjectivity in Literature for Young Readers. Routledge, 2010.

Nodelman, Perry. “Text as Teacher: The Beginning of Charlotte's Web.” Children's Literature, vol. 13,1985 , pp. 109-127.

---. The Hidden Adult: Defining Children’s Literature. John Hopkins UP, 2008.

---. “The Other: Orientalism, Colonialism, and Children’s Literature.” Children’s Literature Association Quarterly, vol. 35, no. 1, 1992, pp. 29-35.

Pattison, Robert. The Child Figure in English Literature. U of Edinburgh P, 1978.

Pearce, Philippa. Tom's Midnight Garden. Puffin, $195^{8}$.

Plotz, Judith. "Literary Ways of Killing a Child: The Nineteenth-Century Practice.” Aspects and Issues in the History of Children's Literature, edited by Maria Nikolajeva, Greenwood, 1995, pp. 1-24.

---. Romanticism and the Vocation of Childhood. Palgrave, 2001.

Potter, Beatrix. The Complete Adventures of Peter Rabbit and Friends. Frederick Warne, 1994.

Pullman, Philip. Lyra's Oxford. David Fickling, 2003.

---. Northern Lights. Scholastic, 1995.

---. The Amber Spyglass. 2000. Scholastic, 2007.

---. The Subtle Knife. Scholastic, 1997.

Punter, David. The Literature of Terror: A History of Gothic Fictions from 1785 to the Present Day. Rev. Ed., vol. 1: The Gothic Tradition, Longman, 1996.

Punter, David, and Glennis Byron. The Gothic. Blackwell, 2004. 
Rackin, Donald. "Love and Death in Carroll's Alices.” English Language Notes, vol. 20, no. 2, Dec. 1982, pp. 26-45.

Reed, Brian. S-Town. Chapter Three: Tedious and Brief, https://stownpodcast.org/. Accessed 2 Apr. 2017.

Richardson, Alan. Literature, Education and Romanticism: Reading as Social Practice, 17801832. Cambridge UP, 1994.

---. "Romanticism and the End of Childhood.” Nineteenth Century Contexts, vol. 21, no. 2, 1999, pp. 169-89.

Ritvo, Harriet. “Animal Dreams and Animal Reflections.” Victorian Animal Dreams: Representations of Animals in Victorian Literature and Culture, edited by Deborah Denenholz Morse and Martin A Danahay, Ashgate, 2007, pp. 271-75.

Robinson, Joan G. When Marnie Was There. Collins, 1967.

Rose, Jacqueline. The Case of Peter Pan or, The Impossibility of Children's Fiction. 1984. Revised, Macmillan, 1994.

Rosenthal, Adam R. “The Gift of Memory in Baudelaire's 'Morale de Joujou.” NineteenthCentury French Studies, vol. 43, no. 3-4, Spring-Summer 2015, pp. 129-143.

Rousseau, Jean Jacques. Emile, or Education. 1762. Translated by Barbara Foxley, J.M. Dent, 1911.

Rowling, JK. Harry Potter and the Chamber of Secrets. 1998. Bloomsbury, 2002.

---. Harry Potter and the Deathly Hallows. Bloomsbury, 2007.

---. Harry Potter and the Half-Blood Prince. Bloomsbury, 2005.

---. Harry Potter and the Order of the Phoenix. Bloomsbury, 2003. 
---. Harry Potter and the Philosopher's Stone. 1997. Bloomsbury, 1998.

---. Harry Potter and the Prisoner of Azkaban. Bloomsbury, 1999.

Rudd, David. “Animal and Object Stories.” Cambridge Companion to Children's Literature, edited by M.O. Grenby and Andrea Immel, Cambridge UP, 2009, pp. 242-57.

---. “Border Crossings: Carrie’s War, Children's Literature and Hybridity.” New Voices in Children's Literature Criticism, edited by Sebastien Chapleau, Pied Piper, 2004, pp. 63-70.

---. “Children's Literature and the Return to Rose.” Children's Literature Association Quarterly, vol. 35, no. 3, 2010, pp. 290-310.

---. “Digging Up the Family Plot: Secrets, Mystery and the Blytonesque.” Mystery in Children's Literature: From the Rational to the Supernatural, edited by Adrienne E. Gavin and Christopher Routledge, Routledge, 2001, pp. 82-99.

Sage, Victor, and Allan Lloyd Smith. "Introduction.” Modern Gothic: A Reader, edited by Victor Sage and Allan Lloyd Smith, Manchester UP, 1996, pp. 1-5.

Sale, Roger. Fairy Tales and After: From Snow White to EB White. Harvard UP, 1978.

Shuttleworth, Sally. The Mind of the Child: Child Development in Literature, Science and Medicine 1840-190o. Oxford UP, 2010.

Smith, Andrew. Gothic Literature. Edinburgh UP, 2007.

Steedman, Carolyn. Strange Dislocations: Childhood and the Idea of Human Interiority 1780 1930. Harvard UP, 1995.

Stevenson, Robert Louis. “To Any Reader.” 1885. A Child’s Garden of Verses, Victor Gollancz, 1985 , p. 118. 
Samuel, Raphael. Theatres of Memory. Vol. I: Past and Present in Contemporary Culture, Verso, 1994.

Shirasu, Yasuko. The Illustrator's Interpretation of a Time Travel Fantasy: Susan Einzig and Tom's Midnight Garden. 2008, http://human.kanagawau.ac.jp/gakkai/publ/pdf/no166/16608\%20.pdf. Accessed 2 June 2016.

Stewart, Susan. On Longing: Narratives of the Miniature, the Gigantic, the Souvenir, the Collection. Duke U.P., 1993.

Sutton-Smith, Brian. Toys as Culture. Gardner, 1986.

Shakespeare, William. Hamlet. 1603. Edited by T.J.B. Spencer, Penguin, 1980.

Taylor, Alexander L. The White Knight: A Study of C.L. Dodgson. 1952. Folcroft Library Editions, 1974 .

Tennyson, Alfred Lord. Poems and Plays. London: Oxford UP, 1967

Terdiman, Richard. Present Past: Modernity and the Memory Crisis. Cornell U.P., 1993.

Thackeray, William. "De Juventute, Roundabout Papers.-no. VIII." The Cornhill Magazine, vol. 2, no. 10, 1860, pp. 501-512, British Periodicals, https://search.proquest.com/docview/6592260?accountid=14782.

The Bible. King James Version, Zonferdan, 1995.

Townsend, John Rowe. Written for Children: An Outline of English-Language Children's

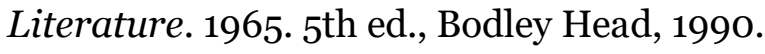

Townshend, Dale. “The Haunted Nursery: 1764-1830.” The Gothic in Children's Literature: Haunting the Borders, edited by Anna Jackson et al., Routledge, 2008, pp. 15-38. 
Turner, Beatrice. "'You Know Very Well You're Not Real': Victorian Fantasy Literature and the Problem of Writing the Child." MA thesis, Victoria University of Wellington, 2009, http://hdl.handle.net/10063/1274.

Vassilopoulou, Panayiota, and Jornadon Ganeri. "The Geography of Shadows: Souls and Cities in P. Pullman’s His Dark Materials.” Philosophy and Literature, vol. 35, no. 2, Oct. 2011, pp. 269-81.

Watson, Victor. “The Possibilities of Children's Fiction.” After Alice: Exploring Children's Literature, edited by Morag Styles et al., Cassell, 1992, pp. 11-24.

White, E. B. "A Book is a Sneeze." Letters of Note, edited by Shaun Usher, 2 August 2013, www.lettersofnote.com/2013/o8/a-book-is-a-sneeze.html. Accessed 28 June 2017.

---. Charlotte's Web. Puffin, 1952.

White, T. H. The Once and Future King. Collins, 1958.

---. The Sword in the Stone. Collins, 1938.

Wierda Rowland, Ann. Romanticism and Childhood: The Infantilization of British Literary Culture. Cambridge UP, 2012.

Williams, Margery. The Velveteen Rabbit: Or How Toys Become Real. 1922. Heinemann, 1970. Williams, Raymond. The Country and the City. Chatto and Windus, 1973.

Wordsworth, William. "Ode: Intimations of Immortality from Recollections of Early Childhood." 1807. The Oxford Anthology of English Literature, vol. II: 1800 to the Present, Oxford UP, 1973, pp. 176-81. 
Wullschläger, Jackie. Inventing Wonderland: Victorian Childhood as Seen Through the Lives and Fantasies of Lewis Carroll, Edward Lear, JM Barrie, Kenneth Grahame, and AA Milne. Free Press, 1995.

Yolen, Jane. Hobby. Scholastic, 1996.

---. Merlin. Scholastic, 1997.

---. Passager. Harcourt Brace, 1996. 